TITLE:

\title{
Rhombognathine Mites (Acari : Halacaridae) from Hokkaido, Northern Japan
}

$\operatorname{AUTHOR}(\mathrm{S})$ :

Abe, Hiroshi

\section{CITATION:}

Abe, Hiroshi. Rhombognathine Mites (Acari : Halacaridae) from Hokkaido, Northern Japan. PUBLICATIONS OF THE SETO MARINE BIOLOGICAL LABORATORY 1996, 37(1-2): 63166

\section{ISSUE DATE:}

1996-02-29

URL:

http://hdl.handle.net/2433/176254

RIGHT: 


\title{
Rhombognathine Mites (Acari : Halacaridae) from Hokkaido, Northern Japan
}

\author{
HIROSHI ABÊ \\ Department of Marine Sciences and Technology, School of Engineering, \\ Hokkaido Tokai University, Sapporo, 005 Japan
}

\begin{abstract}
A total of 16 species of mites in the subfamily Rhombognathinae (Acari: Halacaridae) are recorded from Hokkaido, northern Japan. Five Isobactrus and six Rhombognathus new species are described, viz. Isobactrus dentatus sp. nov., I. gryposetus sp. nov., I. hamatus sp. nov., I. latistriatus sp. nov., I. tuberculatus sp. nov., Rhombognathus compressus sp. nov., $R$. incertus sp. nov., $R$. medialis sp. nov., $R$. neotenus $\mathrm{sp}$. nov., $R$. tenuiformis sp. nov. and $R$. teurinus sp. nov. Two Rhombognathus species new to Japan, $R$. leurodactylus Krantz, 1976 and $R$. sinensis Bartsch, 1990, are described on the basis of Japanese specimens. Three known species, $R$. atuy Abé, 1990, $R$. dissociatus Abé, 1990 and $R$. ezoensis Abé, 1990, are redescribed on the basis of the paratype specimens. Key to the species and notes of habitats and distributional range for each species are presented. Their occurrence on various substrates in Hokkaido is examined by a correspondence analysis. The analysis indicates no distinct association of rhombognathine species with substrates in Hokkaido.
\end{abstract}

\section{Introduction}

The rhombognathine mites are small free living mites commonly found in coastal sea waters of the world. There is rich information on the rhombognathine fauna in the North Atlantic and related seas (Trouessart, 1889a, b; Lohmann, 1889, 1893 ; Viets, 1927a, b, 1936, 1939, 1940 ; André, 1946 ; Sokolov, 1952 ; Bartsch, 1972, 1975a, b, 1979a ; Green \& Macquitty, 1987). On the other hand, only a few works exist on the North Pacific fauna: Newell (1947), Sokolov (1952) and Abé (1990b) referred to the western North Pacific fauna, and Krantz (1976) to the eastern fauna. In the adjacent waters of Japan, there are only two reports on the species of this subfamily: Sokolov (1952) described two species of the genus Rhombognathus from the Japan Sea coast in Russia ; Abé (1990b) reported three Rhombognathus species from the coast of Hokkaido, northern Japan.

The present paper aims to fill in the gap of faunal knowledge in the North Pacific. I describe 13 species newly recorded from the area and give a key to all the known species and notes of their distributional pattern and habitat preferences.

\section{Materials and Methods}

All the materials examined in the present study were collected during 1989 to 1993 at 56 localities on the coasts of the Japan Sea, the Okhotsk Sea, and the western North Pacific in Hokkaido, northern Japan (Fig. 1). Most samples were collected in the intertidal zone less than $0.5 \mathrm{~m}$ depth, and some samples were taken in the subtidal zone deeper than several meters. At each locality various substrates as algae, mussels, sand, stone, and organic detritus were taken by hand or by a dredge and a Smith-McIntyre Grab Sampler. The mites were extracted from the substrates by means of decanting and sieving, and were observed following the procedure formerly described by Abé (1990a) and Abé et al. (1993).

The following abbreviations are used in the description: $\mathrm{AD}$, anterior dorsal plate; $\mathrm{AE}$, anterior epimeral plate; aes-i, anterior epimeral seta(e) on coxa(e) of the first leg(s); aes-ii-lat (-v, -adj), lateral (ventral, adjunctive) seta(e) on coxa(e) of the second leg(s); AP, anal plate; ds-i-v, first to fifth dorsal seta(e); GA, genitoanal plate; GP, genital plate; OC, ocular plate(s) ; P-1-4, first to fourth 

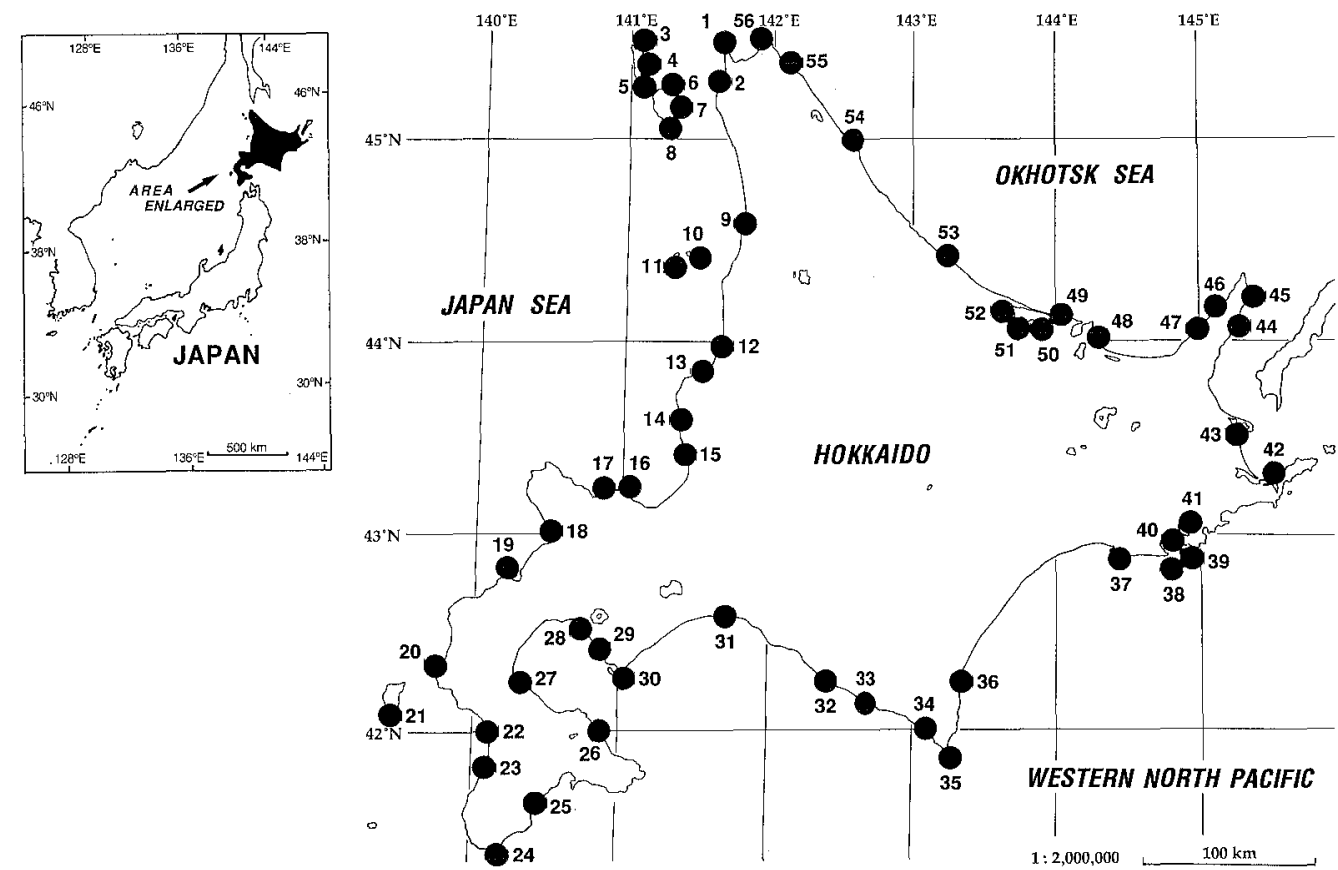

Fig. 1. Map showing the collecting sites in Hokkaido, northern Japan. 1, Wakkanai ; 2, Bakkai ; 3, Horodomari (Rebun Island) ; 4, Kabukai (Rebun Island); 5, Kabuka (Rebun Island) ; 6, Oshidomari (Rishiri Island) ; 7, Nozuka (Rishiri Island) ; 8, Oniwaki (Rishiri Island) ; 9, Shosanbetsu; 10, Teuri Island; 11, Yagishiri Island ; 12, Rumoi ; 13, Mashike ; 14, Hamamasu; 15, Atsuta ; 16, Shukutsu; 17, Oshoro ; 18, Tomari ; 19, Tateiwa ; 20, Hutoro ; 21, Aonae (Okushiri Island) ; 22, Tateura ; 23, Kaminokuni ; 24, Shirakami ; 25, Kikonai ; 26, Usujiri ; 27, Yakumo ; 28, Usu ; 29, Date ; 30, Muroran ; 31, Tomakomai ; 32, Shizunai ; 33, Mitsuishi ; 34, Samani; 35, Erimo ; 36, Hiroo ; 37, Kushiro ; 38, Nakanose ; 39, Daikoku Island ; 40, Aininkappu ; 41, Lake Akkeshi (with Bekanbe-ushi River); 42, Tôbai ; 43, Odaitô ; 44, Rausu; 45, Aidomari ; 46, Utoro ; 47, Oshinkoshin ; 48, Masuura ; 49, Tokoro ; 50, Sakaeura ; 51, Kimuaneppu ; 52, Barou ; 53, Monbetsu ; 54, Esashi ; 55, Ômisaki ; 56, Sôya.

segment(s) of palp(i); PD, posterior dorsal plate ; PE, posterior epimeral plate(s) ; pes-iii-lat (-v, -adj), lateral (ventral, adjunctive) seta(e) on coxa(e) of the third leg(s); pes-iv, seta(e) on coxa(e) of the fourth leg(s); pes-iv-a (-p), anterior (posterior) seta(e) on coxa(e) of the fourth leg(s).

The following abbreviations are used in the figure legends: Ds, dorsal view ; L, left appendage or part; $\mathrm{R}$, right appendage or part; $\mathrm{Vr}$, ventral view. In addition, the following abbreviations are used in the figure 2: ADPL, anterior dorsal plate-length; ADPW, anterior dorsal plate-width; AEPL, anterior epimeral plate-length; AEPW, anterior epimeral plate-width; APW, anal platewidth; BCSL, basal cheliceral segment-length; GNL, gnathosoma-length; GNW, gnathosomawidth; GPL, genital plate-length; GPW, genital plate-width; IDL, Idiosoma-length; IDW, idiosoma-width; LGL, leg-length; MDL, movable digit-length; OCPL, ocular plate-length ; PDPL, posterior dorsal plate-length; PDPW, posterior dorsal plate-width; PEPL, posterior epimeral platelength; PLL, palp-length; ROL, rostrum-length.

The body parts are measured in the following format (Fig. 2) : 1) Idiosoma : length - from the anterior most margin of anterior dorsal plate to the terminal end of anal papilla along longitudinal median axis; width - at the level of lateral coxal margin of leg III. 2) Plate, genital foramen, and spermatophorotype: length - from the anterior margin to the posterior margin along longitudinal 

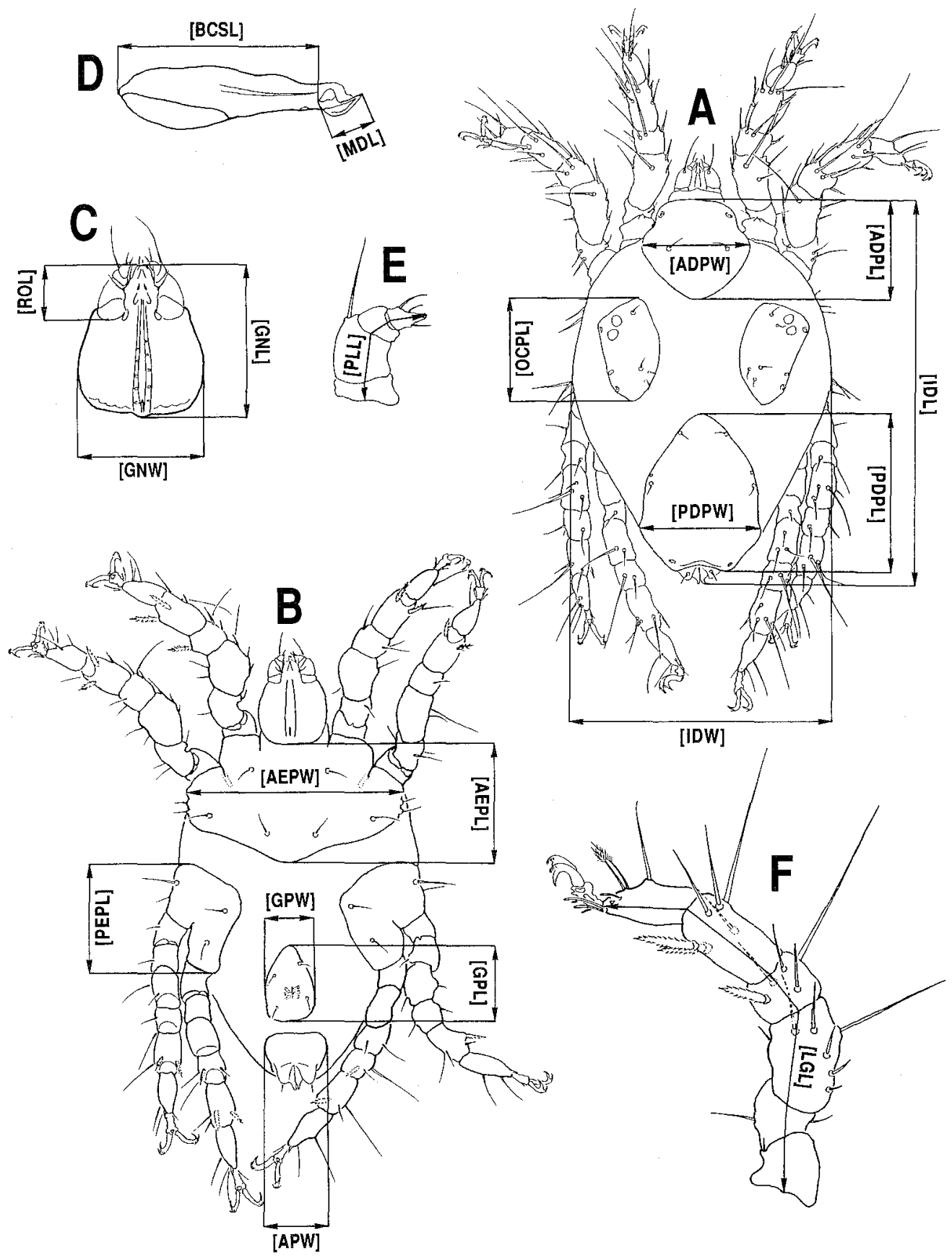

Fig. 2. Parts of body and legs measured. A, body (Ds); B, body (Vr) ; C, gnathosoma (Vr) ; D, chelicera ; E, palp ; F, leg. For abbreviations of measured parts, see text. 
median axis; width - at the widest level. 3) Gnathosoma : length - from the anterior tip of rostrum to the posterior margin of the base of gnathosoma along longitudinal median axis; width - at the widest level. 4) Rostrum : length - from the anterior tip of rostrum to the level of the base of palpal insertions along longitudinal median axis. 5) Basal cheliceral segment: length - from the most proximal end of the segment to the base of the movable digit. 6) Movable digit: length - from the base to the distal end of the dorsal denticulate edge. 7) Palp : length - from the base of the trochanter to the distal end of the tibiotarsus along longitudinal median axis. 8) Leg : length - from the base of the trochanter to the distal end of tarsal claw fossa along longitudinal median axis.

The description of each species is based on a single specimen. Additional descriptions for the opposite sex and immatures are also provided, if possible.

The type specimens are deposited in the National Science Museum, Tokyo, and the United States National Museum, Washington, D.C. Some of the paratype specimens are retained in the author's private collection.

Metric characters are always given in micrometer $(\mu \mathrm{m})$. Meristic characters are sometimes given as ranges (e.g. the number of accessory teeth). Leg chaetotaxy is expressed as "tibiae I-IV, 6-6-5-5" which means that the tibia of the first to the fourth legs have $6,6,5$ and 5 setae respectively. The arrangement of subgenital setae is expressed as "arranged 2-1" which means that the anterior portion of genital sclerites has two pairs of setae, and the posterior portion has one pair of setae.

As regards the appendages, the terms "anterior," "posterior," "proximal," "distal," "dorsal" and "ventral" are used to express a position relative to the longitudinal axis of the appendage when the appendage projects from the body perpendicularly to the longitudinal axis of the body. The term "medial" is used to express a position near the longitudinal median axis in both the body and the appendages.

\section{Description of the Rhombognathines in Hokkaido}

Key to genera

1. Gnathosoma almost or completely concealed in dorsal view. Ocular plates not furnished with setae. Ventral plates developed only on each coxal region.

........................................ Isobactrus Newell, 1947

Gnathosoma recognizable in dorsal view. Each ocular plate furnished with two setae. Ventral plates well developed in adults, occasionally fused into a single plate.

Rhombognathus Trouessart, 1888

\section{Genus Isobactrus Newell, 1947}

[Japanese name: Ojigidani]

Diagnosis. Each ocular plate without setae. One of two corneae completely reduced. Dorsal setae four or five pairs. Ventral plates usually reduced to small plates surrounding each coxae. Genital opening of the female ventrally placed. Perigenital setae of the female three pairs. Gnathosoma directed ventrally, concealed in dorsal view. Palpi four segmented. Tarsus I furnished with clavate solenidion and rudimentary famulus. Tarsus II with one clavate solenidion. Carpite moniliform proximally. All tarsi with two claws.

\section{Key to species}

1a. A conspicuous hook present on ventroproximal edge of claw-shaft. Accessory process

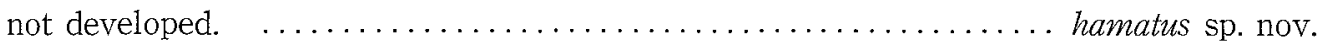

1b. A hook absent on claw-shaft. Accessory process developed. $\quad \ldots \ldots \ldots \ldots \ldots \ldots 2$

2a. Costae well developed on dorsal plates. Accessory process bearing tiny single tooth. Basal fossary seta on each tarsus long and strongly bending at terminal end. 
2b. Costae inconspicuous. Accessory process bearing several teeth. Basal fossary seta on

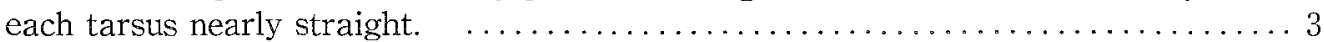

3a. Membranous cuticle on dorsum clearly tuberculate. $\ldots \ldots \ldots \ldots$ tuberculatus sp. nov.

3b. Membranous cuticle on dorsum not tuberculate. $\quad \ldots \ldots \ldots \ldots \ldots \ldots \ldots \ldots \ldots \ldots$

4a. Membranous cuticle on dorsum thickly striated. Accessory process bearing several fine teeth. $\ldots \ldots \ldots \ldots \ldots \ldots \ldots \ldots \ldots \ldots \ldots \ldots \ldots \ldots \ldots \ldots \ldots \ldots \ldots \ldots \ldots \ldots \ldots \ldots \ldots$ latistriatus sp. nov.

4b. Membranous cuticle on dorsum finely striated. Accessory process bearing several strong teeth. dentatus sp. nov.

\section{Isobactrus dentatus sp. nov. \\ [Japanese name: Kumade-ojigidani]}

(Figs. 3-6)

Type series. Holotype: Female, among Mytilus edulis on ledge, intertidal, Oshoro (Kabuto Rock), Japan Sea coast of Hokkaido, 22.iii.1989, H. Abé coll. Allotype: Male, data same as the holotype. Paratypes : 3 females and 3 males, data same as the holotype; 1 deutonymph, among Lomentaria hakodatensis on exposed boulders, intertidal, Shukutsu, Japan Sea coast of Hokkaido, 27.x.1993, H. Abé coll.

Female (holotype)

Idiosoma $372 \mu \mathrm{m}$ long, $248 \mu \mathrm{m}$ wide. Color in life dark green with a fine dorsal semitransparent line longitudinally.

Dorsum (Fig. 3A) : Dorsal plate ornamented with weak panels (Fig. 3C). Dorsal membranous cuticle strongly striated, not tuberculate, furnished with three pairs of subsurface pores between $\mathrm{AD}$ and PD. $\mathrm{AD}$ and PD separated by interval of approximately PD-length. AD 94 $\mu \mathrm{m}$ long, $84 \mu \mathrm{m}$ wide, concave posteriorly, ornamented with clear areolation and a pair of dorsal pores laterally. OC $48 \mu \mathrm{m}$ long, furnished with one large cornea and two tiny polygonal pores. PD $142 \mu \mathrm{m}$ long, $114 \mu \mathrm{m}$ wide, furnished with a pair of small dorsal pores posteriorly. Costae not clear.

Chaetotaxy of dorsal region: Dorsal setae very short and faint except for ds-iii. Setae ds-i on $\mathrm{AD}$; ds-ii each placed on membranous cuticle between $\mathrm{AD}$ and $\mathrm{OC}$; ds-iii long and thick, each on membranous cuticle between $\mathrm{AD}$ and $\mathrm{PD}$; ds-iv and ds-v on PD.

Venter (Fig. 3B) : Epimeral plates weakly developed only on each coxal region. Epimeral region furnished with several subsurface pores medially, and with epimeral pore between insertions of leg I and leg II on each side.

Chaetotaxy of epimeral region: Epimeral setae placed on striated membranous cuticle except for pes-iii-lat. Setae aes-i located at level posteriorly to camerostome; aes-ii-lat placed at posterior to insertion of leg II ; aes-ii-v placed most medially; pes-iii-lat placed dorsally on posterior epimeral plate of coxae III ; pes-iii-v near medial margins of coxae III ; pes-iv placed near coxae IV.

Genitoanal region (Fig. 4A): Genitoanal region surrounded with striated membranous cuticle. Genital foramen $60 \mu \mathrm{m}$ long, $40 \mu \mathrm{m}$ wide, occupying from the level of insertion of leg IV to level anterior to anal foramen. Genital sclerites band-shaped. One pair of very short, and two pairs of large internal genital acetabula are visible. Anal foramen placed terminally on membranous cuticle.

Chaetotaxy of genitoanal region: Three filiform perigenital setae located on each side of genital foramen as arranged in Fig. 4A. Subgenital setae short filiform; one pair on genital sclerites, arranged 1-0.

Gnathosoma (Fig. 3D) : $72 \mu \mathrm{m}$ long, $70 \mu \mathrm{m}$ wide, gnathosomal length/idiosomal length 0 . 19. Base, length/width 0.57 . Rostrum $32 \mu \mathrm{m}$ long, nearly lanceolate, not reaching to level of distal end of palp. Rostral setae two pairs at swollen point, both long and thick. Chelicera 


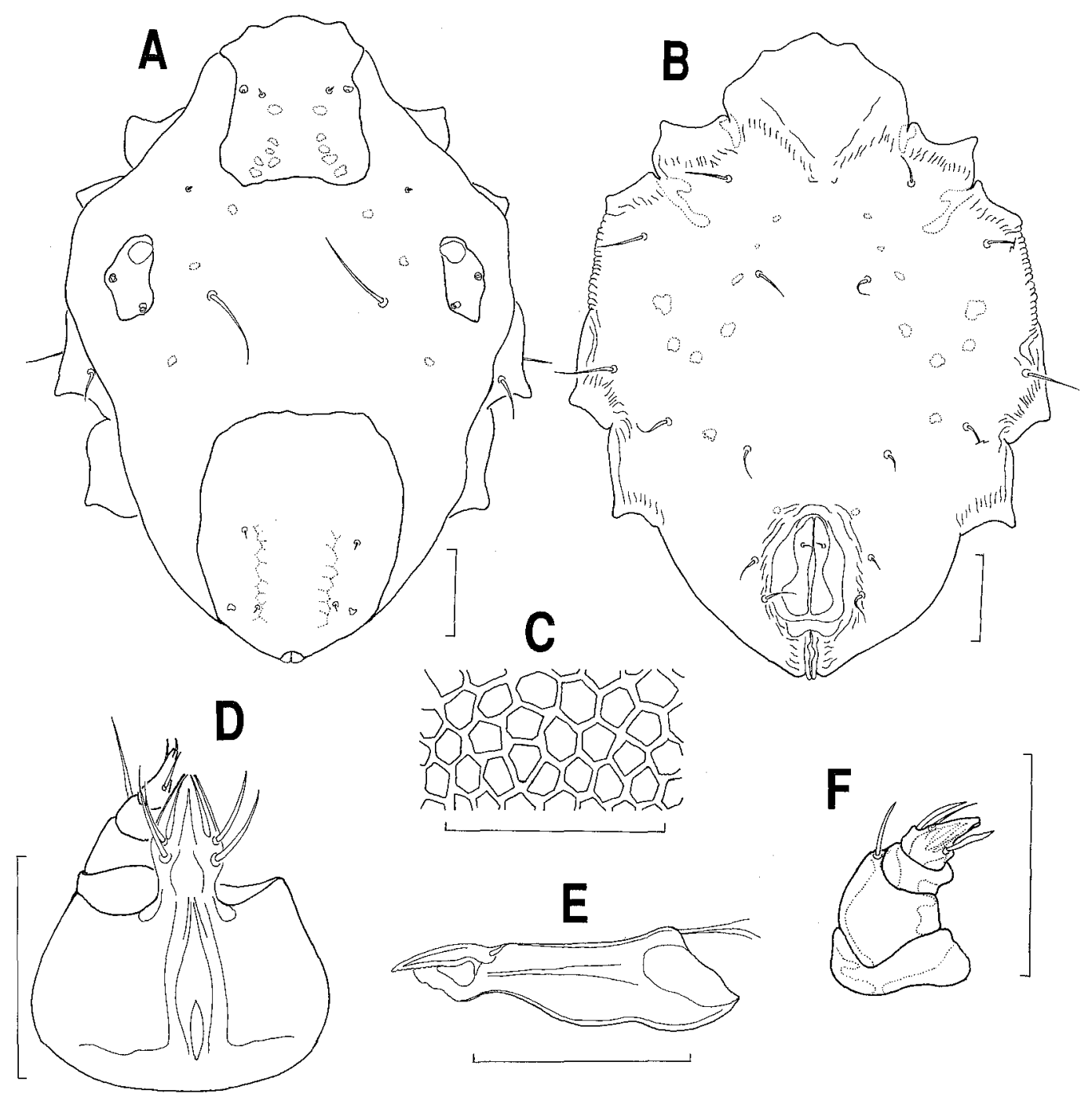

Fig. 3. Isobactrus dentatus sp. nov., female (holotype). A, idiosoma (Ds); B, idiosoma (Vr); C, panels on PD; D, gnathosoma (Vr) (left palp omitted) ; E, chelicera (R) ; F, palp (L). Scale bars $=50$ $\mu \mathrm{m}$.

(Fig. 3E) with basal segment $60 \mu \mathrm{m}$ long; movable digit $16 \mu \mathrm{m}$ long, with seven to nine minute denticulations along dorsal edge. Fixed digit weakly developed. Palp (Fig. 3F) $44 \mu \mathrm{m}$ long; $\mathrm{P}-1$ short and cylindrical ; $\mathrm{P}-2$ longest and robust, with a thick filiform seta distidorsally ; $\mathrm{P}-3$ short and cylindrical ; $\mathrm{P}-4$ conical, with two blade-like and one fine filiform setae intermediately, and with two appressed blunt spiniform projections terminally.

Legs (Figs. 5A-D) : Length of legs I, II, III, IV $=202,204,204,204 \mu \mathrm{m}$ respectively. Ornamentation indistinct. Lateral claw with four or five robust accessory teeth and faint ventroproximal hook on the shaft.

Leg chaetotaxy as follows: Trochanters I-IV, 1-1-1-0; basifemora I-IV, 2-2-1-0 ; telofemora I-IV, 3-3-2-2; genua I-IV, 3-3-2-2; tibiae I-IV, 5-5-5-5. As for large 

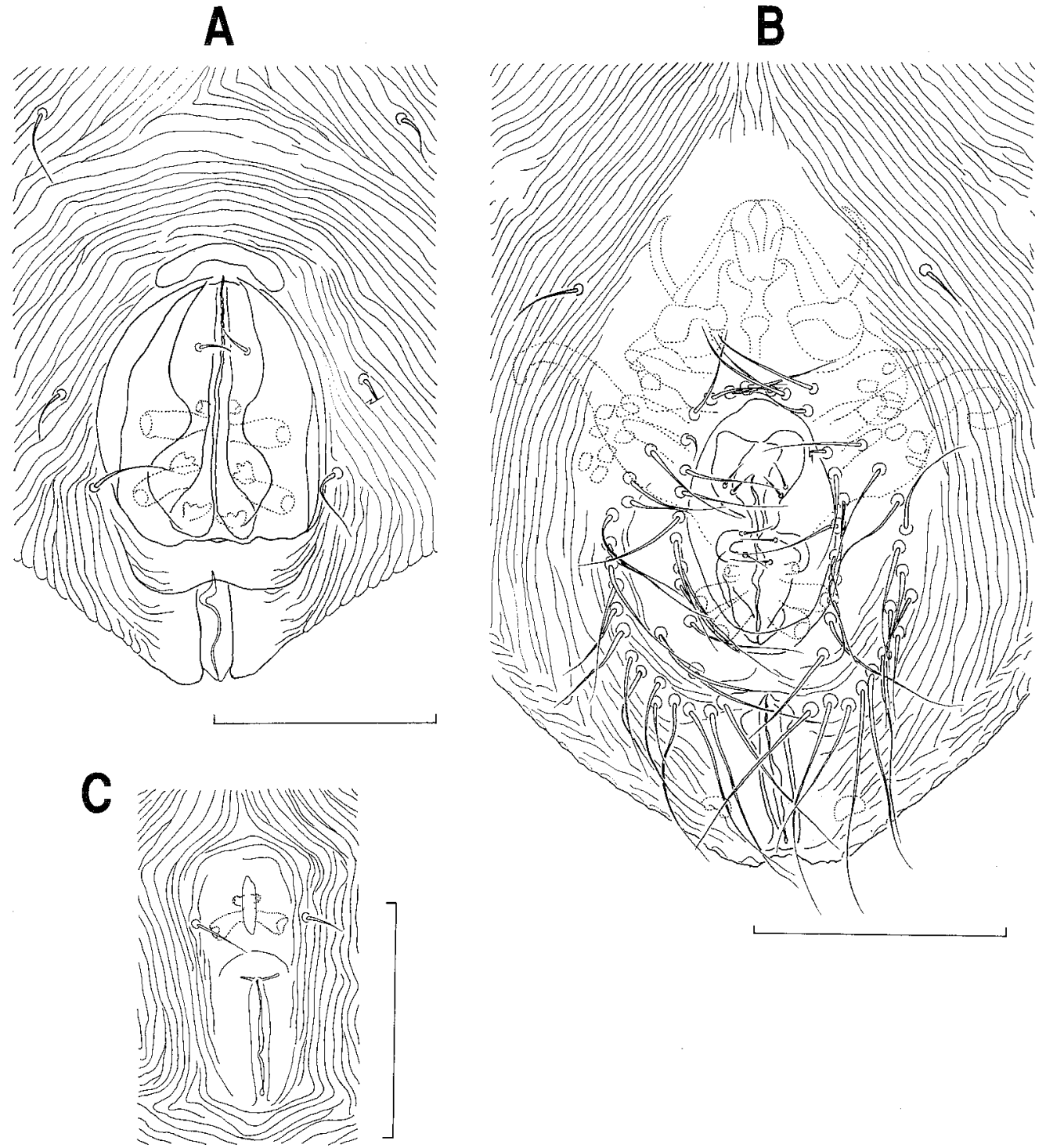

Fig. 4. Isobactrus dentatus sp. nov., genitoanal regions. A, female (holotype) ; B, male (allotype); C, deutonymph (paratype). Scale bars $=50 \mu \mathrm{m}$.

bipectinate setae: Tibiae I-IV, 1-0-0-0. Tarsus I (Fig. 6A) with three dorsal setae, one solenidion, one vestigial famulus, and four parambulacral setae (paired doublet euphathidia). Solenidion bacilliform on posterodorsal surface of claw fossa. Famulus very faint at just ventrally to solenidion. Tarsus II (Fig. 6B) with three dorsal setae, one solenidion, and four parambulacral setae. Solenidion bacilliform on posterodorsal surface of claw fossa. Tarsus III (Fig. 6C) with four dorsal setae and two parambulacral setae (one single euphathidium on posterior surface, one divaricate proeuphathidium on anterior surface). Tarsus IV (Fig. 6D) with three dorsal setae (one filiform seta on basal claw fossa, two weakly plumose setae on distal claw fossa) and two parambulacral setae (one fine euphathidium on posterior surface, 

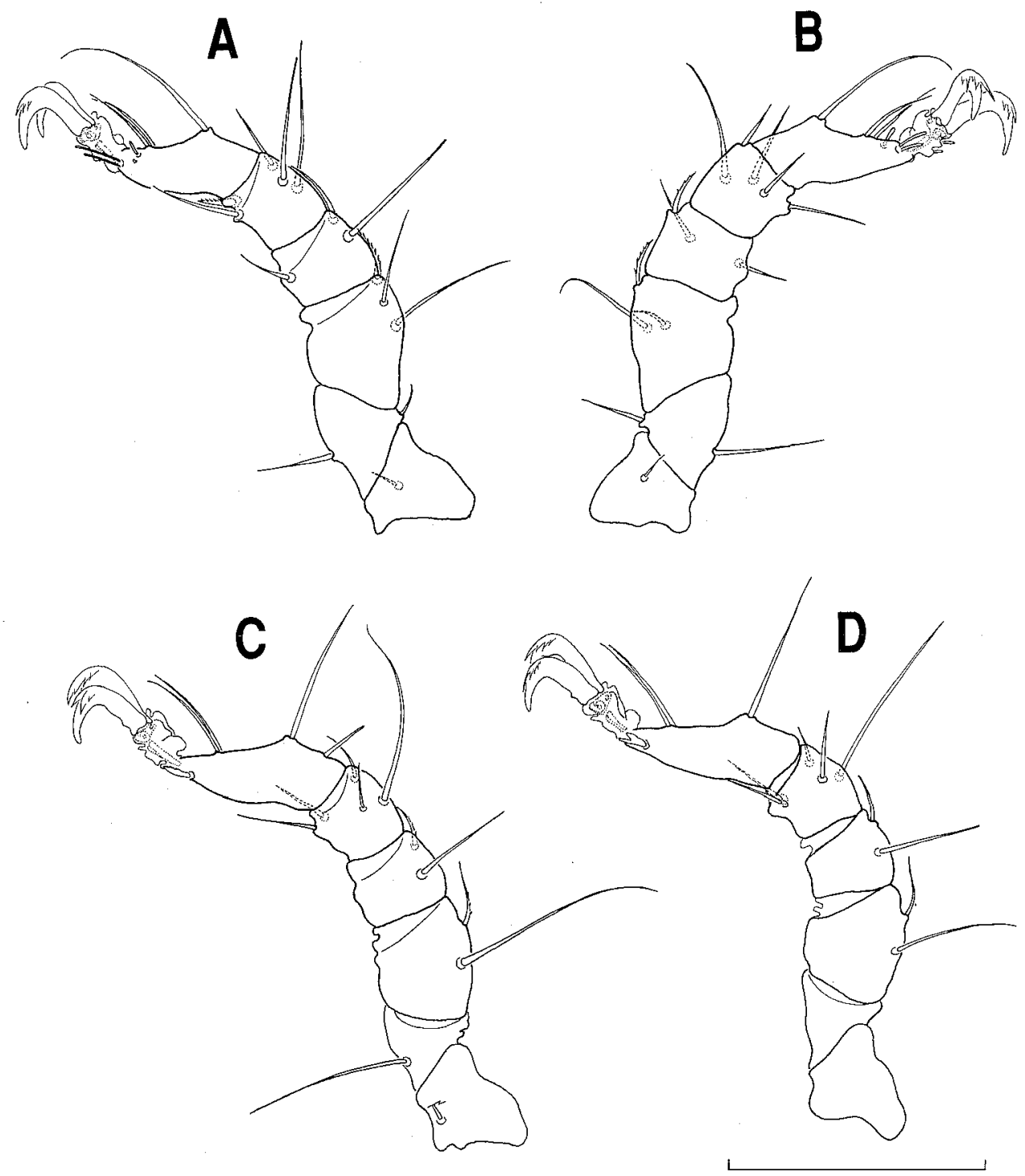

Fig. 5. Isobactrus dentatus sp. nov., female (holotype). A, leg I (L) ; B, leg II (L) ; C, leg III (R) ; D, leg IV (R). Scale bar $=100 \mu \mathrm{m}$.

one divaricate proeuphathidium on anterior surface).

Male (allotype).

Idiosoma $340 \mu \mathrm{m}$ long, $224 \mu \mathrm{m}$ wide, gnathosoma-length/idiosoma-length 0.18 , resembling the female in essential respects except for character states of genitoanal region.

Genitoanal region (Fig. 4B) furnished with long filiform 61 perigenital setae as arranged in Fig. 4B. Membranous cuticle weakly sclerotized around genital foramen. Genital foramen $46 \mu \mathrm{m}$ long, $30 \mu \mathrm{m}$ wide. Subgenital setae four pairs on genital sclerites, arranged $2-2$. Genital acetabula two pairs. Spermatophorotype (cf. Fig. 4B) $72 \mu \mathrm{m}$ long, $64 \mu \mathrm{m}$ wide, massive and rhombic. 

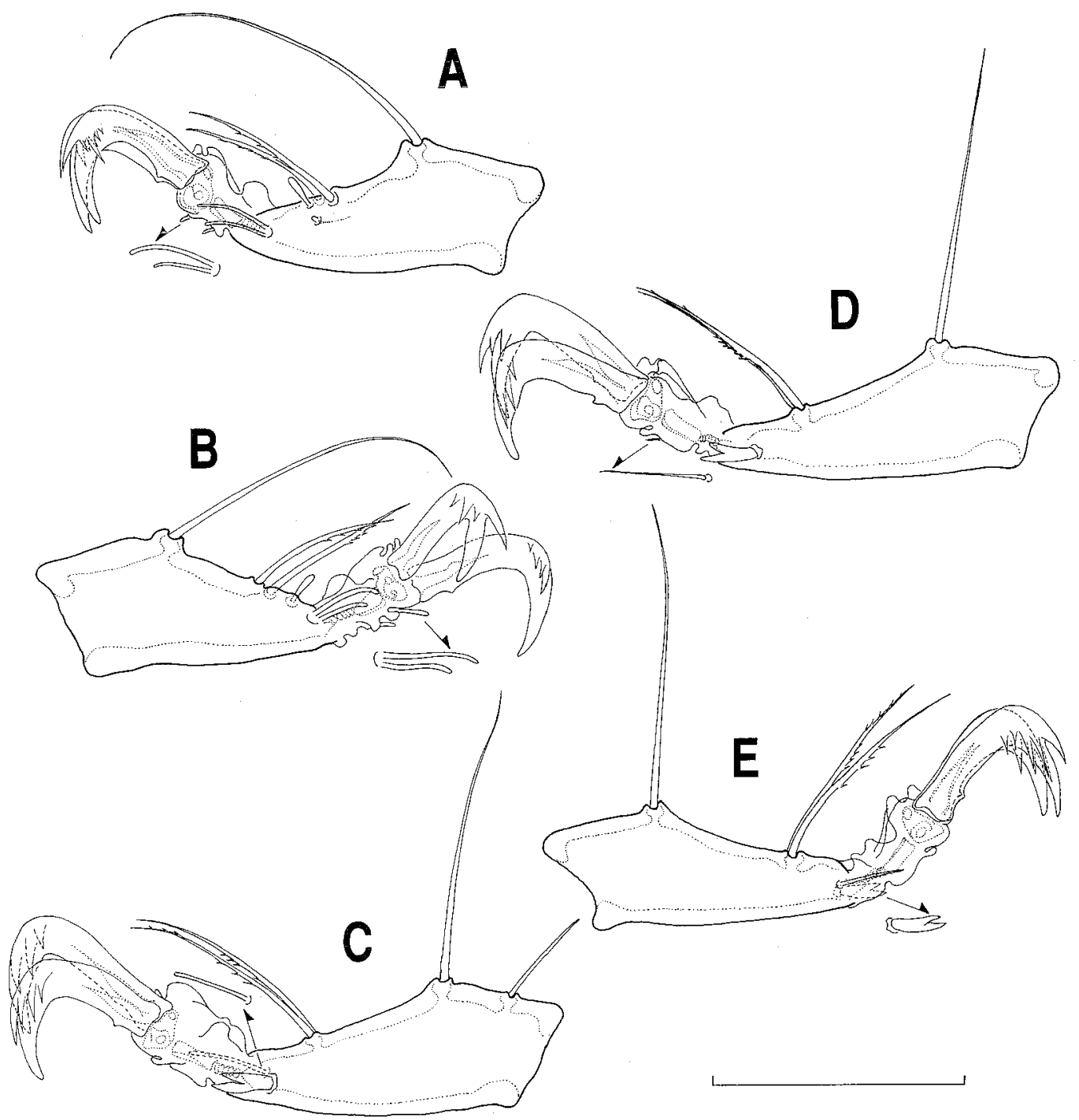

Fig. 6. Isobactrus dentatus sp. nov., female (holotype). A, tarsus I (L); B, tarsus II (L) ; C, tarsus III (R); D, tarsus IV (R). Male (allotype). E, tarsus IV (R). Scale bar $=50 \mu \mathrm{m}$.

Tarsus IV (Fig. 6E) resembles that in the female.

Deutonymph (paratype)

Idiosoma $228 \mu \mathrm{m}$ long, $152 \mu \mathrm{m}$ wide, gnathosoma-length/idiosoma-length 0.20 .

Dorsum : AD $72 \mu \mathrm{m}$ long, $58 \mu \mathrm{m}$ wide, faintly concave posteriorly. PD $74 \mu \mathrm{m}$ long, $80 \mu \mathrm{m}$ wide, convex anteriorly. AD and PD separated by interval of PD-length. OC $26 \mu \mathrm{m}$ long. Two pairs of subsurface pores located between $\mathrm{AD}$ and $\mathrm{PD}$.

Venter : Epimeral plate developed only on each coxal region. Epimeral region furnished with several subsurface pores medially.

Genitoanal region (Fig. 4C) : Genital region furnished with one pair of perigenital setae, bearing a tiny subsurface pore on each lateral region. Primordial genital slit surrounded by 
faintly sclerotized membranous cuticle, furnished with two pairs of internal genital acetabula.

Legs : Length of legs I, II, III, IV $=126,126,130,124 \mu \mathrm{m}$ respectively. Leg chaetotaxy of trochanters I-IV , 1-1-1-0 ; basifemora I-IV, 2-2-1-0 ; telofemora I-IV , 3-3-2-2 ; genua I-IV, 3-3-2-2 ; tibiae I-IV, 5-5-5-5. Bipectinate setae on tibiae I-IV, 1-0-0-0.

Morphological variation and abnormality

The size range of the idiosoma, gnathosoma, and legs I-IV in adults as follows.

Female ( $\mathrm{n}=4$ ). Idiosoma-length : $328-372 \mu \mathrm{m}$, -width : $212-248 \mu \mathrm{m}$; gnathosoma-length : 64-74 $\mu \mathrm{m}$, -width : 60-74 $\mu \mathrm{m}$; leg-length : Leg I, 192-214 $\mu \mathrm{m}$; leg II, 192-216 $\mu \mathrm{m}$; leg III, 198 $-210 \mu \mathrm{m}$; leg IV, 198-210 $\mu \mathrm{m}$.

Male $(\mathrm{n}=4)$. Idiosoma-length : $320-348 \mu \mathrm{m}$, -width : 212-224 $\mu \mathrm{m}$; gnathosoma-length : 60-66 $\mu \mathrm{m}$, -width : 60-64 $\mu \mathrm{m}$; leg-length : Leg I, 190-194 $\mu \mathrm{m}$; leg II, 188-194 $\mu \mathrm{m}$; leg III, 188 $-196 \mu \mathrm{m}$; leg IV, $182-192 \mu \mathrm{m}$.

The number of the perigenital setae varies from 61 to 68 in the male.

Remarks

Isobactrus dentatus is recognized on the basis of the lateral claw furnished with robust accessory process bearing four to five strong teeth, and with faint ventroproximal hook on the shaft. I. dentatus resembles I. setosus (Lohmann, 1889) in having robust accessory process, but easily distinguishable from the latter by having four dorsal setae on tarsus III and scarcely developed epimeral plates.

The specific epithet is derived from the strongly dentate accessory process.

Habitat-Intertidal zone: Algae - Lomentaria hakodatensis, Sargassum sp. on boulders. Mussels - Mytilus edulis on ledge.

Distribution in Hokkaido-Hamamasu, Shukutsu, Oshoro.

Isobactrus gryposetus sp. nov.

[Japanese name: Magari-ojigidani]

(Figs. 7-10)

Type series. Holotype : Female, detritus at a depth of $0.1 \mathrm{~m}$, Bekanbe-ushi River (salinity 2.8), Pacific coast of Hokkaido, 17.iii.1990, H. Abé coll. Allotype: Male, data same as the holotype. Paratypes: 3 females, detritus at a depth of $0.2 \mathrm{~m}$, Lake Akkeshi, Pacific coast of Hokkaido, 23. v.1989, H. Abé coll.; 2 females and 3 males, data same as the holotype.

Female (holotype)

Idiosoma: $396 \mu \mathrm{m}$ long, $240 \mu \mathrm{m}$ wide. Color in life dark green with a fine dorsal semitransparent line longitudinally.

Dorsum (Fig. 7A) : Dorsal plate ornamented with clear panels, distinct costae and partly with fine canaliculi (cf. Fig. 7C). Dorsal membranous cuticle not tuberculate, furnished with two pairs of subsurface pores between $\mathrm{AD}$ and $\mathrm{PD}$. $\mathrm{AD}$ and $\mathrm{PD}$ separated by interval of approximately a half of AD-length. AD $142 \mu \mathrm{m}$ long, $96 \mu \mathrm{m}$ wide, concave posteriorly, ornamented with costae and a pair of dorsal pores anteriorly. OC $60 \mu \mathrm{m}$ long, furnished with one large cornea and two tiny polygonal pores. PD $178 \mu \mathrm{m}$ long, $138 \mu \mathrm{m}$ wide, furnished with costae and a pair of small dorsal pores posteriorly.

Chaetotaxy of dorsal region: Dorsal setae very short and faint except for ds-iii. Setae ds-i on $A D$; ds-ii each placed on membranous cuticle between $A D$ and $O C$; ds-iii long and thick, each on membranous cuticle between $\mathrm{AD}$ and PD; ds-iv and ds-v on PD.

Venter (Fig. 7B) : Epimeral plates developed only on each coxal region. Epimeral region furnished with several subsurface pores medially, and with epimeral pore between insertions of leg I and leg II on each side. 


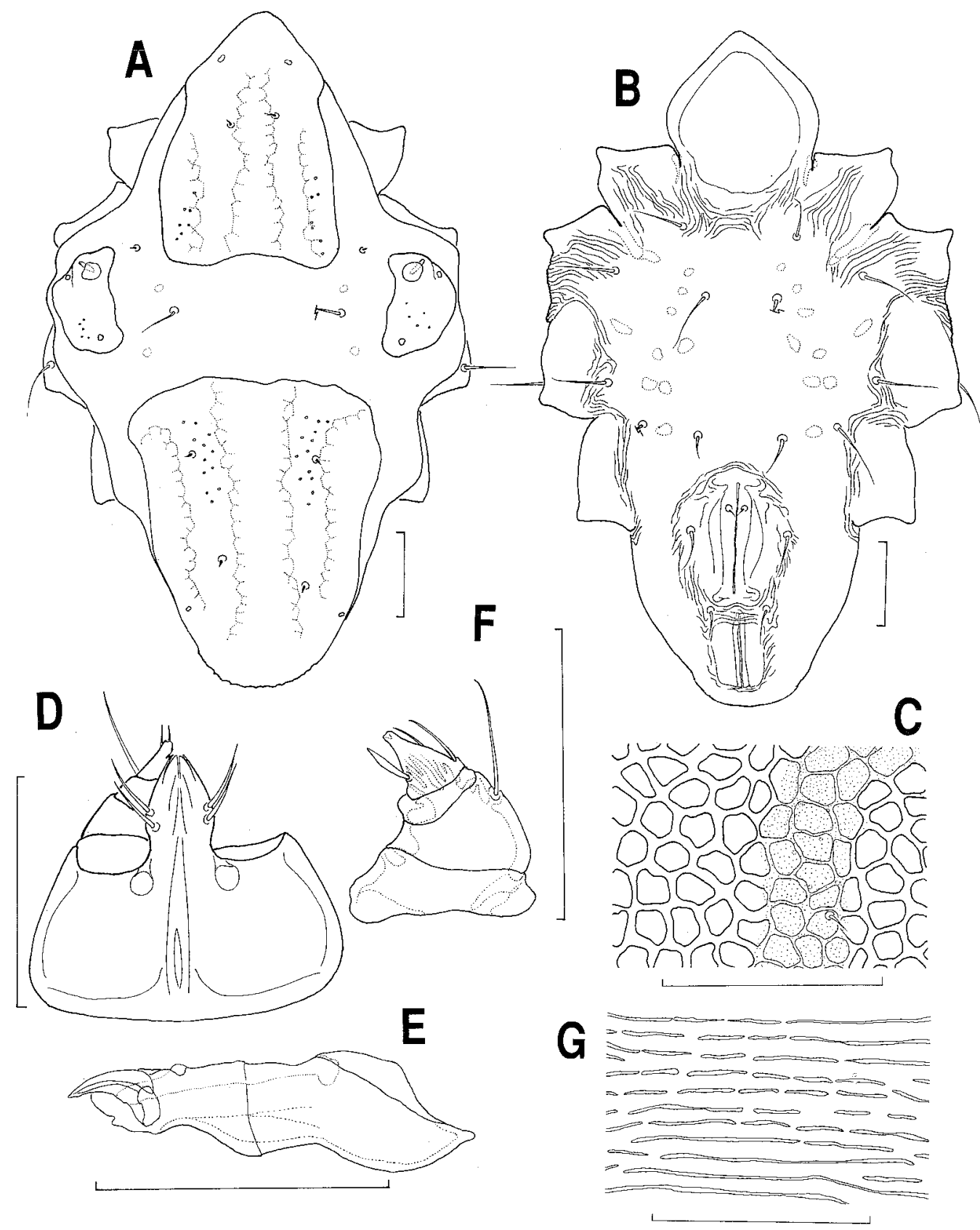

Fig. 7. Isobactrus gryposetus sp. nov., female (holotype). A, idiosoma (Ds) ; B, idiosoma (Vr); C, panels on PD; D, gnathosoma (Vr) (left palp omitted); E, chelicera (L); F, palp (L). Female (paratype). G, striation of membranous cuticle (Ds). Scale bars $=50 \mu \mathrm{m}$. 
Chaetotaxy of epimeral region: Epimeral setae placed on striated membranous cuticle except for pes-iii-lat. Setae aes-i located at level posteriorly to camerostome; aes-ii-lat placed at posterior to insertion of leg II ; aes-ii-v placed most medially; pes-iii-lat placed dorsally on posterior epimeral plate of coxae III ; pes-iii-v near medial margins of coxae III ; pes-iv placed near coxae IV.

Genitoanal region (Fig. 8A): Genitoanal region surrounded with striated membranous cuticle. Genital foramen $72 \mu \mathrm{m}$ long, $34 \mu \mathrm{m}$ wide, occupying from level anterior to insertion of leg IV to level anterior to anal foramen. Genital sclerites band-like. One pair of short indistinct, and two pairs of large internal genital acetabula are visible. Anal foramen placed ventrally on membranous cuticle.

Chaetotaxy of genitoanal region: Three filiform perigenital setae located on each side of genital foramen as arranged in Fig. 8A. Subgenital setae short filiform; one pair on genital sclerites, arranged 1-0.

Gnathosoma (Fig. 7D) : $58 \mu \mathrm{m}$ long, $64 \mu \mathrm{m}$ wide, gnathosoma-length/idiosoma-length 0 . 15. Base, length/width 0.48 . Rostrum $30 \mu \mathrm{m}$ long, nearly lanceolate, not reaching to level of distal end of palp. Rostral setae two pairs at swollen point, both long and thick. Chelicera (Fig. 7E) with basal segment $52 \mu \mathrm{m}$ long, and movable digit $14 \mu \mathrm{m}$ long, without distinct denticulation along dorsal edge. Fixed digit weakly developed. Palp (Fig. 7F) $36 \mu \mathrm{m}$ long ;
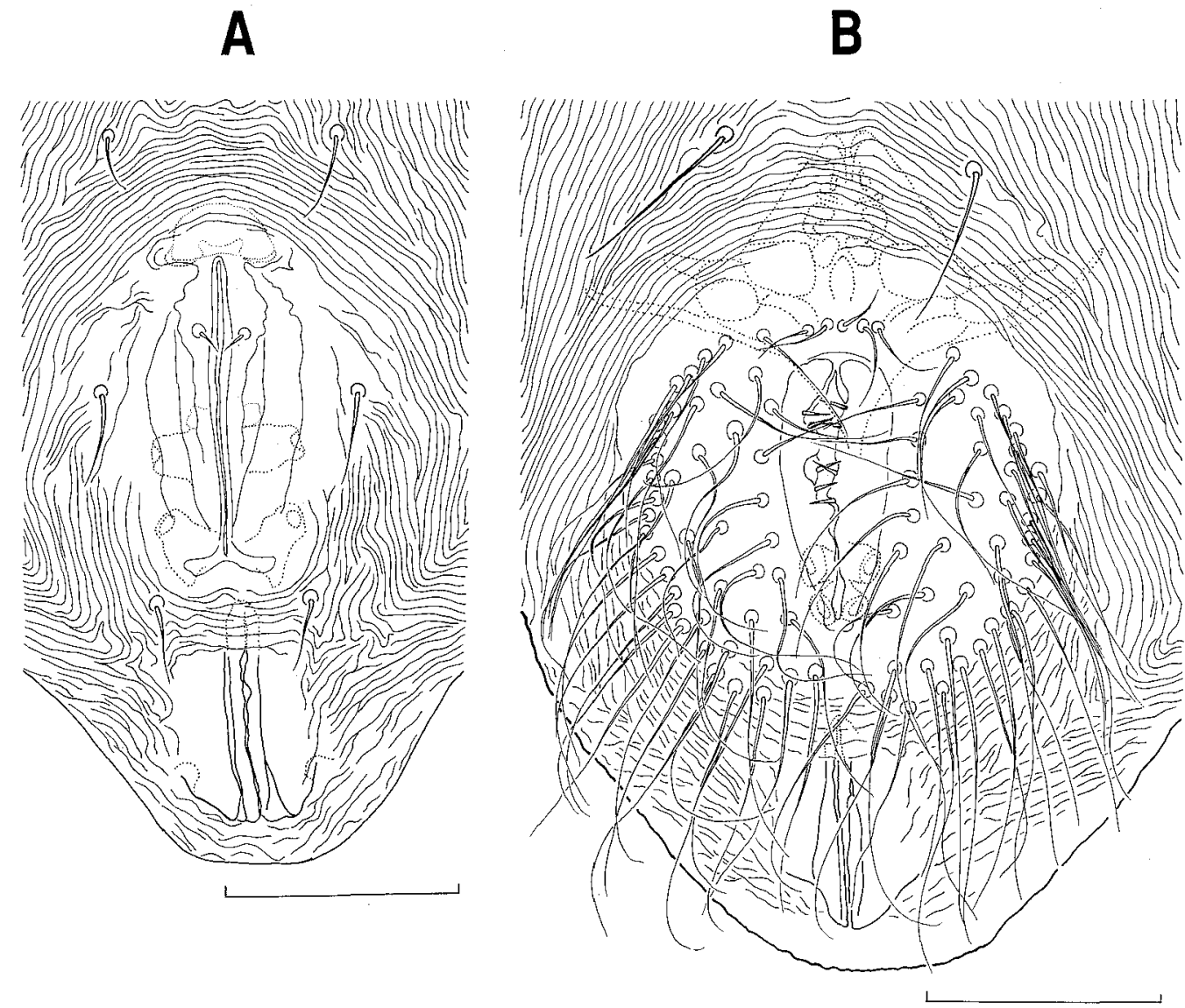

Fig. 8. Isobactrus gryposetus sp. nov., genitoanal regions. A, female (holotype); B, male (allotype). Scale bars $=50 \mu \mathrm{m}$. 


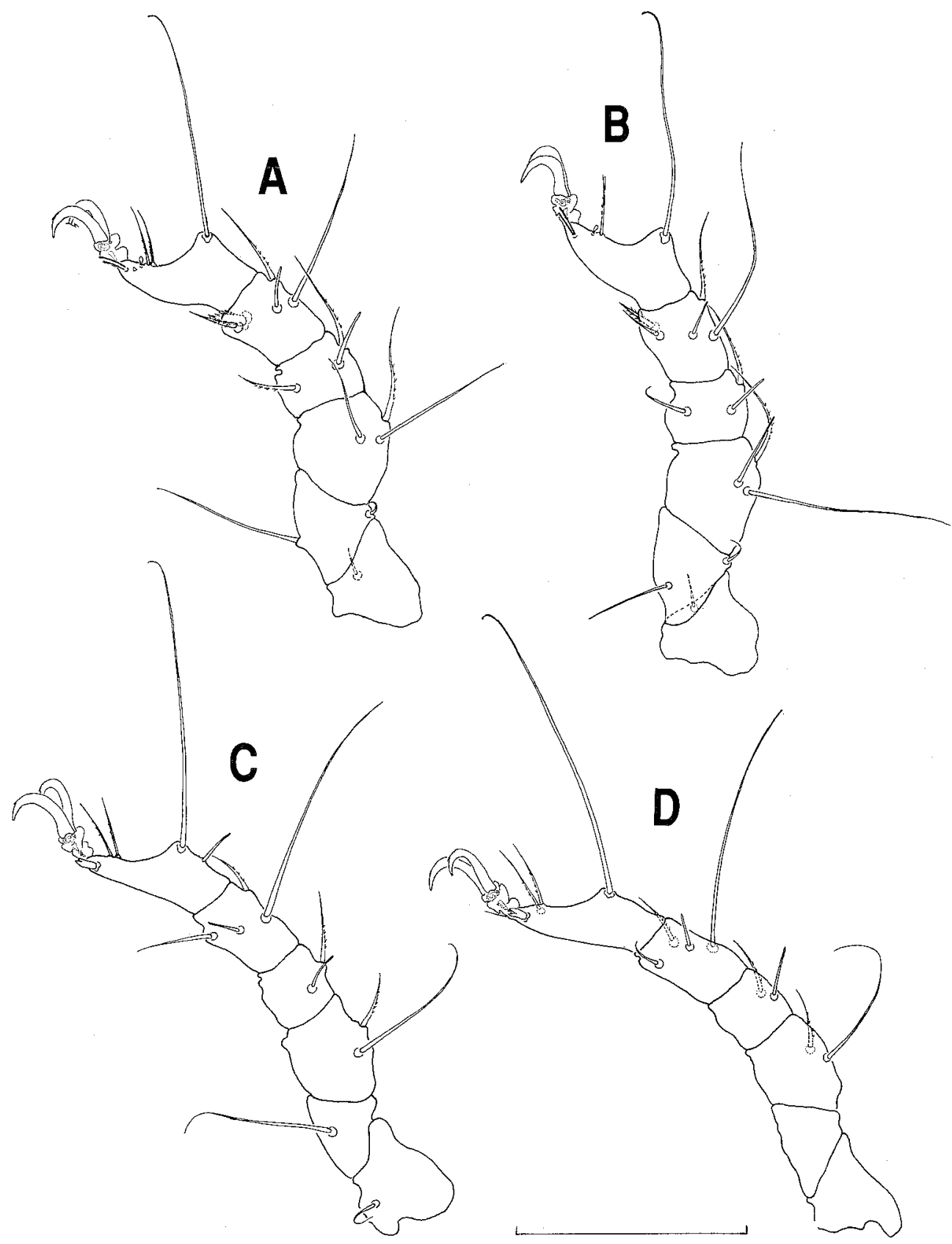

Fig. 9. Isobactrus gryposetus sp. nov., female (holotype). A, leg I (L); B, leg II (L); C, leg III (R); D, leg IV (R). Scale bar $=100 \mu \mathrm{m}$. 


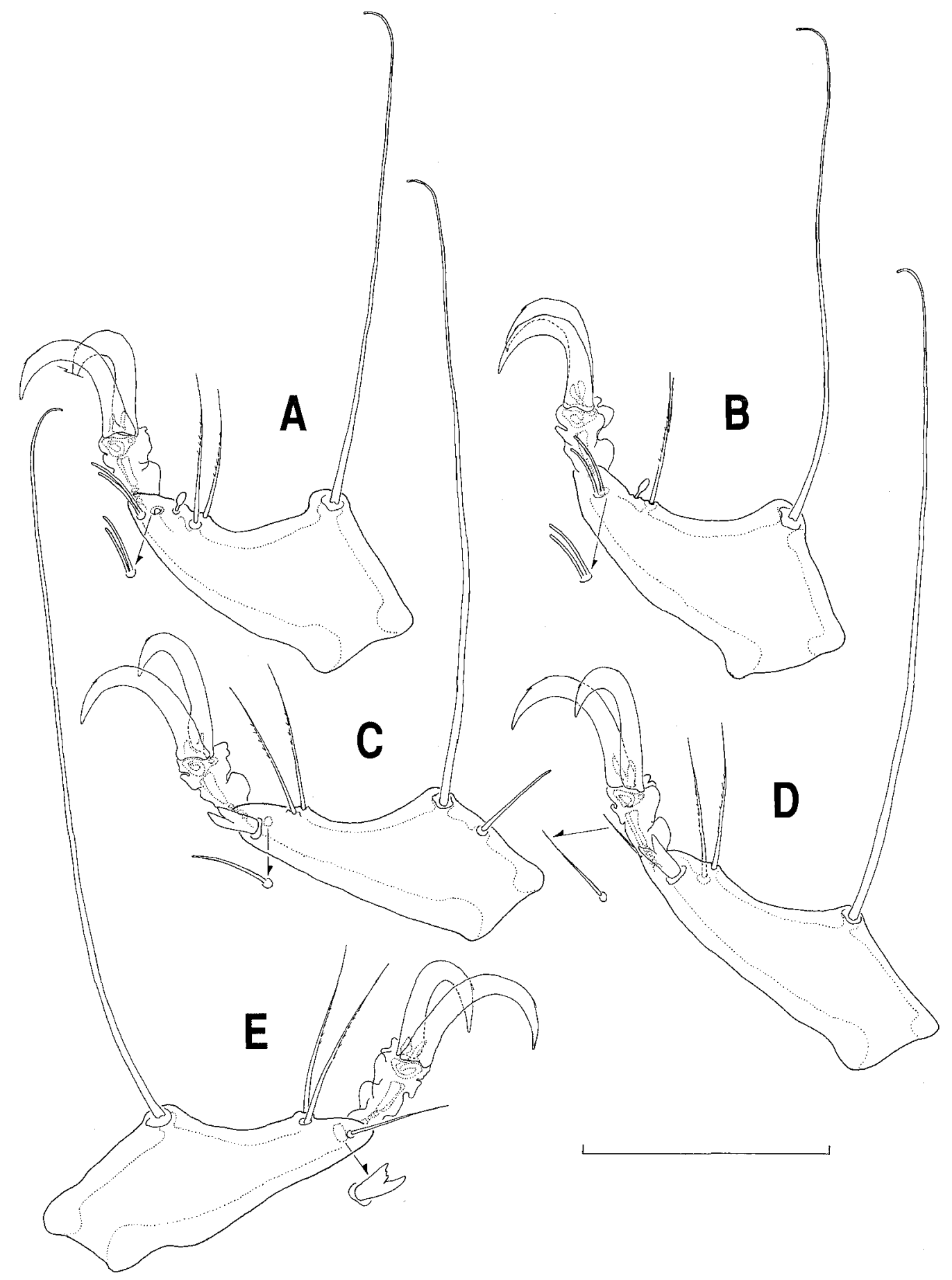

Fig. 10. Isobactrus gryposetus sp. nov., female (holotype). A, tarsus I (L); B, tarsus II (L) ; C, tarsus III (R); D, tarsus IV (R). Male (allotype). E, tarsus IV (R). Scale bar $=50 \mu \mathrm{m}$. 
$\mathrm{P}-1$ short and cylindrical ; $\mathrm{P}-2$ longest and robust, with a thick filiform seta distidorsally ; $\mathrm{P}$ -3 short and cylindrical ; P-4 conical, with two blade-like and one fine filiform setae intermediately, and with two appressed blunt spiniform projections terminally.

Legs (Figs. 9A-D): Length of legs I, II, III, IV $=214,214,220,218 \mu \mathrm{m}$ respectively. Ornamentation indistinct. Lateral claw with very faint accessory tooth.

Leg chaetotaxy as follows: Trochanters I-IV, 1-1-1-0; basifemora I-IV, 2-2-1-0; telofemora I-IV, 3-3-2-2; genua I-IV, 3-3-2-2; tibiae I-IV, 5-5-4-4. As for large bipectinate setae: Tibiae I-IV, 1-0-0-0. Tarsus I (Fig. 10A) with three dorsal setae, one solenidion, one vestigial famulus, and four parambulacral setae (paired doublet euphathidia). Solenidion clavate on posterodorsal surface of claw fossa. Famulus very faint at just ventrally to solenidion. Tarsus II (Fig. 10B) with three dorsal setae, one solenidion, and four parambulacral setae. Solenidion clavate on posterodorsal surface of claw fossa. Tarsus III (Fig. 10C) with four dorsal setae and two parambulacral setae (one single euphathidium on posterior surface, one divaricate proeuphathidium on anterior surface). Tarsus IV (Fig. 10D) with three dorsal setae (one terminally bending filiform seta on basal claw fossa, two weakly plumose setae on distal claw fossa) and two parambulacral setae (one fine euphathidium on posterior surface, one divaricate proeuphathidium on anterior surface). Basal fossary seta of each tarsus is very long and strongly bending at terminal end.

Male (allotype)

Idiosoma $432 \mu \mathrm{m}$ long, $260 \mu \mathrm{m}$ wide, gnathosoma-length/idiosoma-length 0.14 , resembling the female in essential respects except for character states of genitoanal region.

Genitoanal region (Fig. 8B) furnished with long filiform 91 perigenital setae as arranged in Fig. 8B. Membranous cuticle weakly sclerotized around genital foramen. Genital foramen $60 \mu \mathrm{m}$ long, $24 \mu \mathrm{m}$ wide. Subgenital setae four pairs on genital sclerites, arranged 2-2. Genital acetabula two pairs. Spermatophorotype (cf. Fig. 8B) $74 \mu \mathrm{m}$ long, $84 \mu \mathrm{m}$ wide, massive and rhombic.

Tarsus IV (Fig. 10E) similar to that in the female.

Morphological variation and abnormality

The female specimens collected from Lake Akkeshi on 23 May, 1989 have relatively large body size. Some metric character states of the abnormal specimens are given below.

Female (paratype).

Idiosoma $516 \mu \mathrm{m}$ long, $316 \mu \mathrm{m}$ wide, gnathosoma-length/idiosoma-length 0.14 .

Dorsum : $\mathrm{AD}$ and $\mathrm{PD}$ separated by interval more than $\mathrm{AD}$-length. Dorsal membranous cuticle faintly tuberculate (Fig. 7G). AD $148 \mu \mathrm{m}$ long, $104 \mu \mathrm{m}$ wide, reaching posteriorly to level of insertion of leg II. OC $70 \mu \mathrm{m}$ long. PD $196 \mu \mathrm{m}$ long, $160 \mu \mathrm{m}$ wide, reaching anteriorly to level between insertions of leg III and leg IV.

Venter: Genital foramen $82 \mu \mathrm{m}$ long, $32 \mu \mathrm{m}$ wide, reaching anteriorly to the level of the insertion of leg IV.

Legs: Length of legs I, II, III, IV $=230,232,234,232 \mu \mathrm{m}$ respectively.

The size range of the idiosoma, gnathosoma, and legs I-IV in adults as follows.

Female (Lake Akkeshi, $\mathrm{n}=3$ ). Idiosoma-length: 484-516 $\mu \mathrm{m}$, -width: 228-324 $\mu \mathrm{m}$; gnathosoma-length : $70 \mu \mathrm{m}$, -width : 70-72 $\mu \mathrm{m}$; leg-length: Leg I, $220-230 \mu \mathrm{m}$; leg II, $232-$ $234 \mu \mathrm{m}$; leg III, $228-240 \mu \mathrm{m}$; leg IV, 232-238 $\mu \mathrm{m}$.

Female (Bekanbe-ushi River, $\mathrm{n}=3$ ). Idiosoma-length : $396-432 \mu \mathrm{m}$, -width : $240-260 \mu \mathrm{m}$; gnathosoma-length : 58-60 $\mu \mathrm{m}$, -width : $64-68 \mu \mathrm{m}$; leg-length : Leg I, $208-214 \mu \mathrm{m}$; leg II, 208 $-214 \mu \mathrm{m}$; leg III, $218-228 \mu \mathrm{m}$; leg IV, $218-230 \mu \mathrm{m}$.

Male $(\mathrm{n}=4)$. Idiosoma-length : 400-432 $\mu \mathrm{m}$, -width : $240-260 \mu \mathrm{m}$; gnathosoma-length : 56-62 $\mu \mathrm{m}$, -width : 64-66 $\mu \mathrm{m}$; leg-length : Leg I, 196-212 $\mu \mathrm{m}$; leg II, 200-220 $\mu \mathrm{m}$; leg III, 204 
$-222 \mu \mathrm{m}$; leg IV, 202-230 $\mu \mathrm{m}$.

One female specimen from Lake Akkeshi has one additional perigenital seta on the left side of the genital foramen. The number of the perigenital setae varies from 72 to 91 in the male. One female specimen from Bekanbe-ushi River has one large bipectinate seta also on tibia II.

Remarks

Isobactrus gryposetus is easily distinguishable from related species in having a long terminally bending basal fossary seta on each tarsus, dorsal plates with distinct costae, two dorsal setae on posterior dorsal plate, and accessory process with a faint single tooth.

I. gryposetus is regarded as an euryhaline species, being found in a wide salinity range of about $3-32$.

The specific epithet is derived from the terminally bending (grypo-) basal fossary seta on each tarsus.

Habitat-Intertidal and subtidal zones: Algae - Fucus evanescens on intertidal boulders, Agarum cribrosum at subtidal zone. Detritus at 0.1-0.2 $\mathrm{m}$ depth (salinity 2.8).

Distribution in Hokkaido - Nakanose, Aininkappu, Lake Akkeshi, (Bekanbe-ushi River).

Isobactrus hamatus sp. nov.

[Japanese name: Kagizume-ojigidani]

(Figs. 11-14)

Type series. Holotype: Male, Sargassum thunbergii on flat, intertidal, Oshoro (Shamodomari), Japan Sea coast of Hokkaido, 10.iv.1988, H. Abé coll.

Male (holotype)

Idiosoma $392 \mu \mathrm{m}$ long, $280 \mu \mathrm{m}$ wide. Color in life dark green.

Dorsum (Fig. 11A) : Dorsal plate ornamented with weak panels (Fig. 11C), and partly with fine canaliculi. Dorsal membranous cuticle strongly striated, not tuberculate, furnished with several subsurface pores. $\mathrm{AD}$ and $\mathrm{PD}$ separated by interval about a half of $\mathrm{AD}$-length. $\mathrm{AD} 112 \mu \mathrm{m}$ long, $126 \mu \mathrm{m}$ wide, truncated posteriorly, ornamented with weak areolation and a pair of tiny dorsal pores anteriorly. OC $46 \mu \mathrm{m}$ long, furnished with one large cornea and one tiny pore-like structure posteriorly. PD $202 \mu \mathrm{m}$ long, $158 \mu \mathrm{m}$ wide. Dorsal pores and costae indistinct.

Chaetotaxy of dorsal region: Dorsal setae vestigial except for ds-iii. Setae ds-i on AD ; ds-ii each placed on membranous cuticle between $\mathrm{AD}$ and $\mathrm{OC}$; ds-iii long and thick, each on membranous cuticle between $\mathrm{AD}$ and $\mathrm{PD}$; ds-iv and ds-v on PD.

Venter (Fig. 11B) : Epimeral plates weakly developed only on each coxal region. Ventral membranous cuticle more finely striated than dorsum. Epimeral region furnished with several subsurface pores medially, and with epimeral pore between insertions of leg I and leg II on each side.

Chaetotaxy of epimeral region: Epimeral setae placed on striated membranous cuticle except for pes-iii-lat. Setae aes-i located at level posteriorly to camerostome; aes-ii-lat placed at posterior to insertion of leg II ; aes-ii-v placed most medially ; pes-iii-lat placed dorsally on posterior epimeral plate of coxae III ; pes-iii-v on medial margins of coxae III ; pes-iv placed near coxae IV.

Genitoanal region (Fig. 12D) : Genitoanal region surrounded with weakly sclerotized membranous cuticle. Genital foramen $54 \mu \mathrm{m}$ long, $34 \mu \mathrm{m}$ wide, occupying from level of the pes-iv to level anterior to anal foramen. Two pairs of large internal genital acetabula are visible. Spermatophorotype (cf. Fig. 12D) $90 \mu \mathrm{m}$ long, $66 \mu \mathrm{m}$ wide, massive and rhombic. 


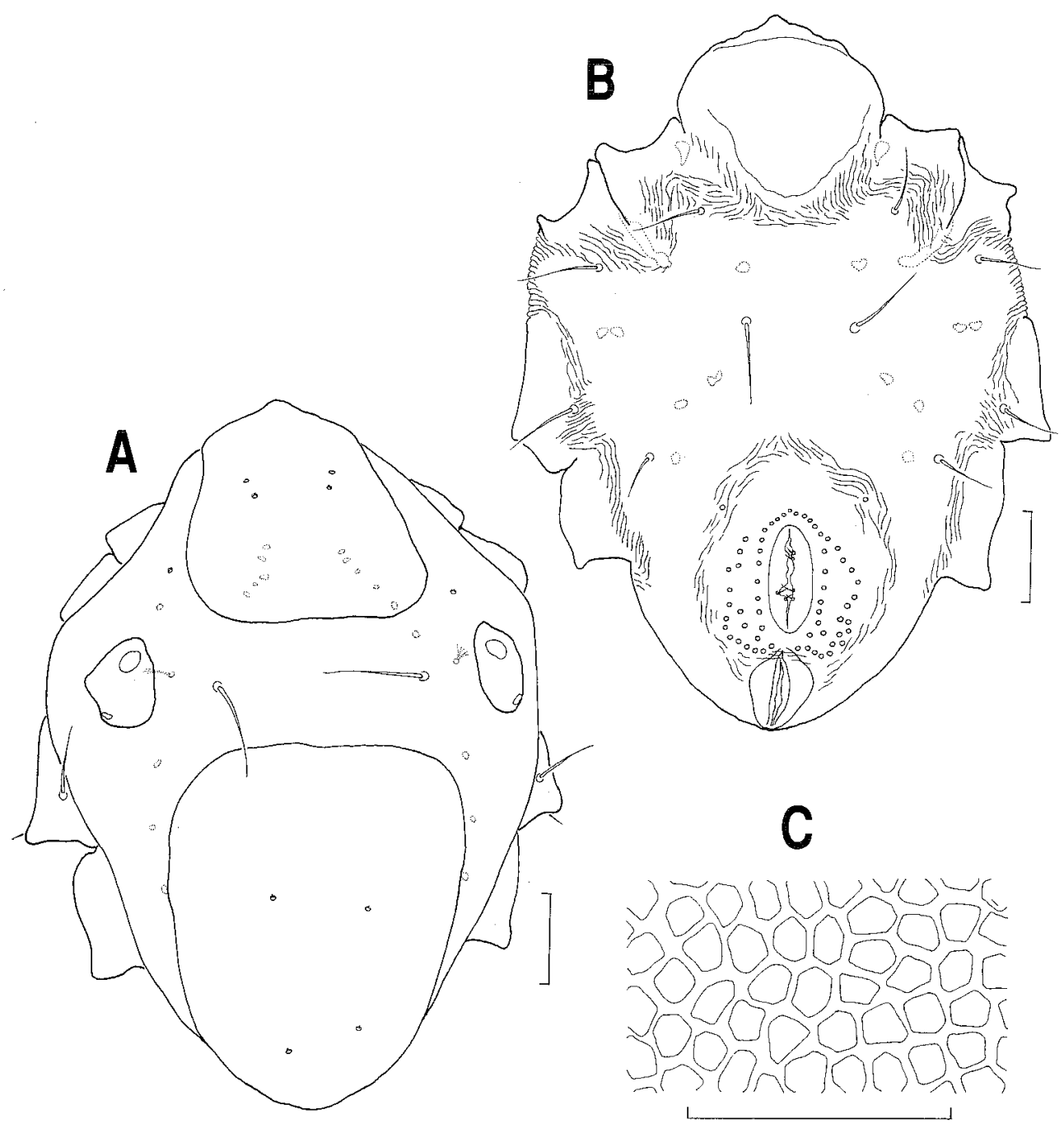

Fig. 11. Isobactrus hamatus sp. nov., male (holotype). A, idiosoma (Ds); B, idiosoma (Vr) (perigenital setae omitted); C, panels on PD. Scale bars $=50 \mu \mathrm{m}$.

Anal foramen placed subterminally on membranous cuticle.

Chaetotaxy of genitoanal region: Long filiform 62 perigenital setae surrounding the genital foramen as arranged in Fig. 12D. Subgenital seta indistinct, but four pairs should be present.

Gnathosoma (Fig. 12A) : $70 \mu \mathrm{m}$ long, $70 \mu \mathrm{m}$ wide, gnathosoma-length/idiosoma-length 0 . 18. Base, length/width 0.57. Rostrum $34 \mu \mathrm{m}$ long, nearly lanceolate, not reaching to level of distal end of palp. Rostral setae two pairs at swollen point, both long and thick. Chelicera (Fig. 12B) with basal segment $62 \mu \mathrm{m}$ long, and movable digit $18 \mu \mathrm{m}$ long, without distinct denticulation along dorsal edge. Fixed digit weakly developed. Palp (Fig. 12C) $42 \mu \mathrm{m}$ long; $\mathrm{P}-1$ short and cylindrical ; $\mathrm{P}-2$ longest and robust, with a thick filiform seta distidorsally; $\mathrm{P}$ -3 short and cylindrical; $\mathrm{P}-4$ conical, with two thick and one fine filiform setae intermediately, and with two appressed blunt spiniform projections terminally. 

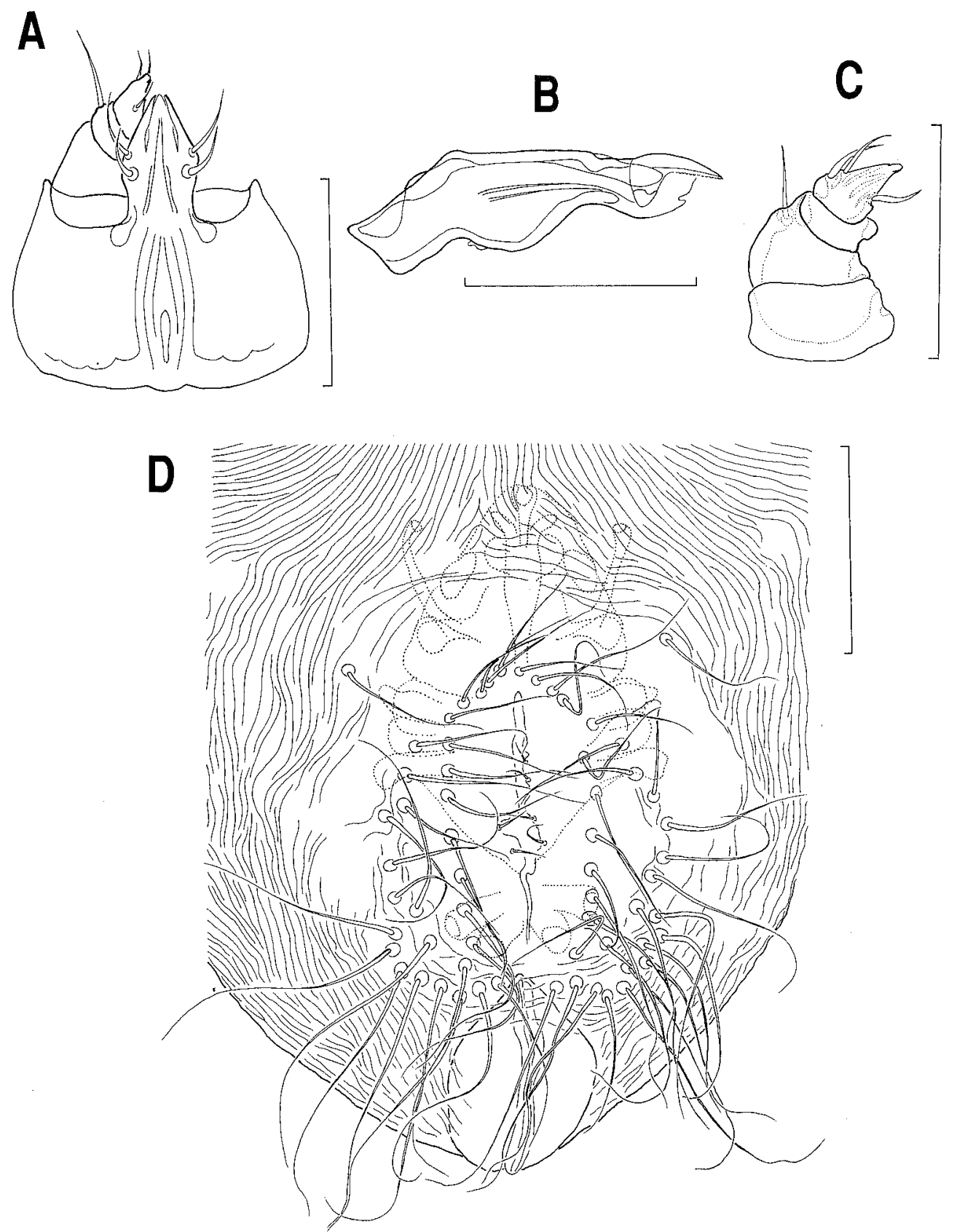

Fig. 12. Isobactrus hamatus sp. nov., male (holotype). A, gnathosoma (Vr) (left palp omitted); B, chelicera (R); C, palp (L) ; D, genitoanal region. Scale bars $=50 \mu \mathrm{m}$. 


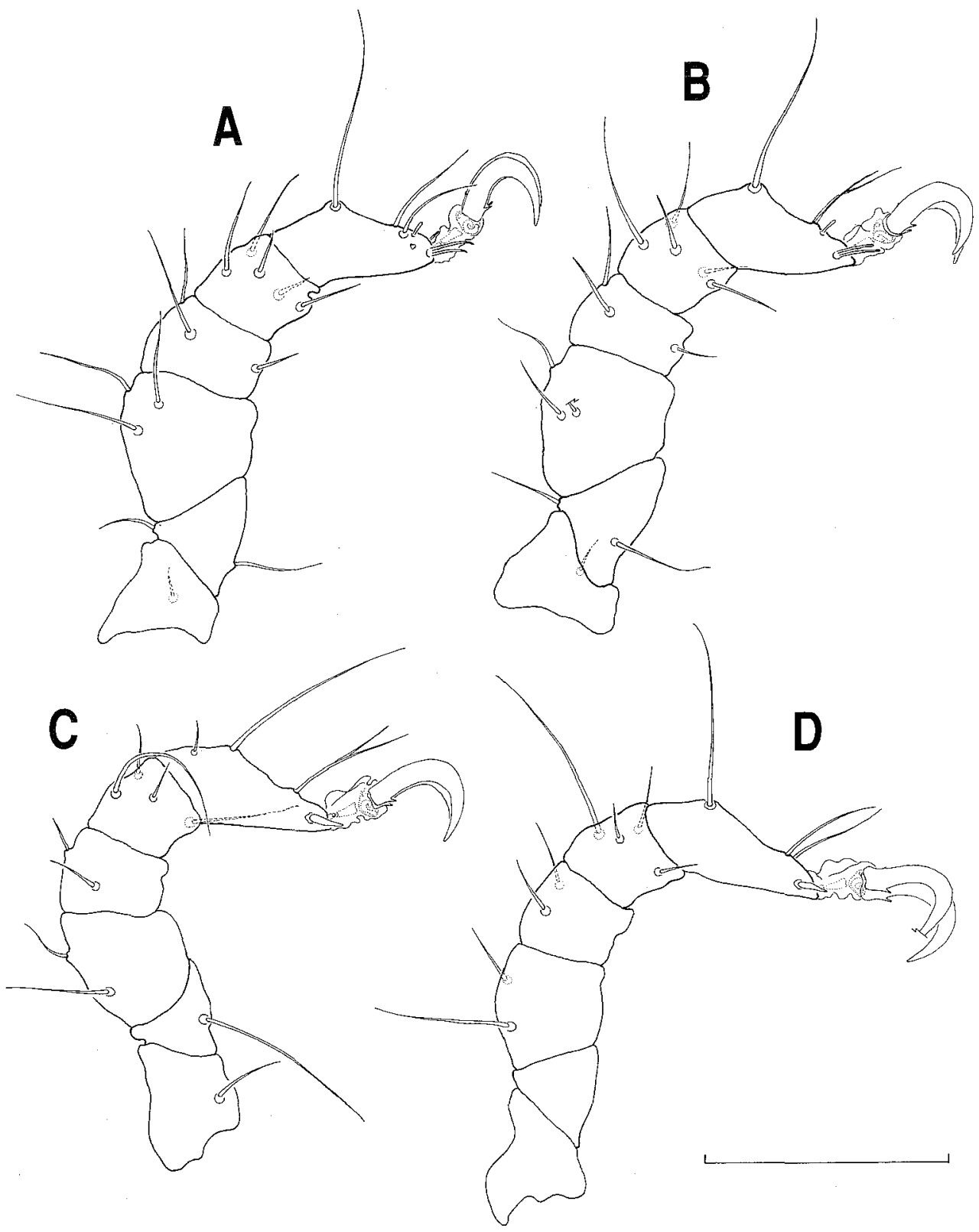

Fig. 13. Isobactrus hamatus sp. nov., male (holotype). A, leg I (R); B, leg II (R); C, leg III (L); D, leg IV (L). Scale bar $=100 \mu \mathrm{m}$.

Legs (Figs. 13A-D) : Length of legs I, II, III, IV $=230,226,224,232 \mu \mathrm{m}$ respectively. Ornamentation indistinct. Lateral claw large, furnished with very faint dorsal and distinct ventroproximal hooks on the shaft, without accessory teeth. Legs without large bipectinate setae.

Leg chaetotaxy as follows: Trochanters I-IV, 1-1-1-0; basifemora I-IV, 2-2-1-0 ; 


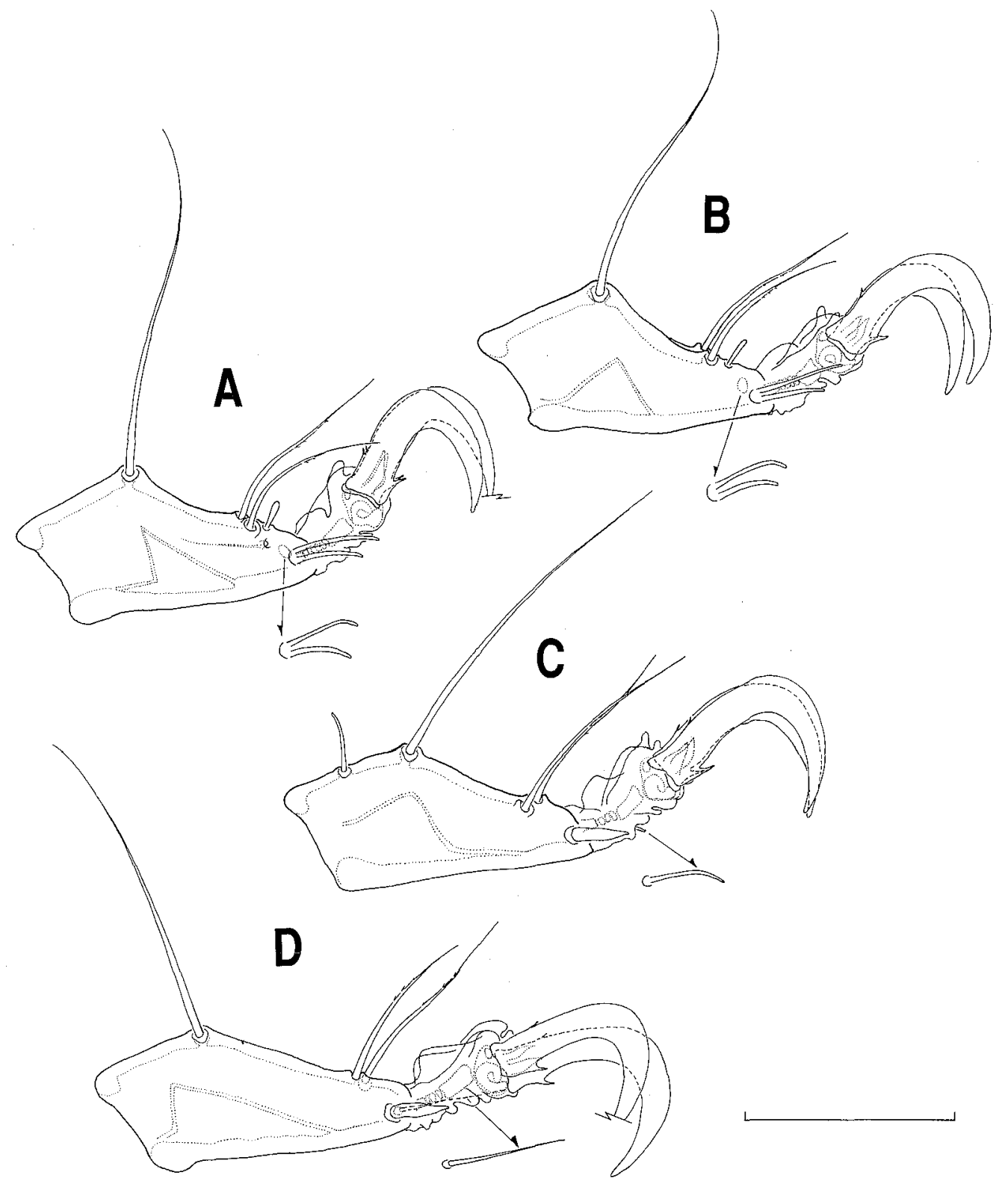

Fig. 14. Isobactrus hamatus sp. nov., male (holotype). A, tarsus I (R); B, tarsus II (R) ; C, tarsus III (L); D, tarsus IV (L). Scale bar $=50 \mu \mathrm{m}$.

telofemora I-IV, 3-3-2-2; genua I-IV, 3-3-2-2 ; tibiae I-IV, 5-5-4-4. Tarsus I (Fig. 14A) with three dorsal setae, one solenidion, one vestigial famulus, and four parambulacral setae (paired doublet euphathidia). Solenidion bacilliform on posterodorsal surface of claw fossa. Famulus very faint at just ventrally to solenidion. Tarsus II (Fig. 14B) with three dorsal setae, one solenidion, and four parambulacral setae. Solenidion bacilliform on posterodorsal surface of claw fossa. Tarsus III (Fig. 14C) with four dorsal setae and two parambulacral setae (one single euphathidium on posterior surface, one scaliform proeuphathidium on 
anterior surface). Tarsus IV (Fig. 14D) with three dorsal setae (one filiform seta on basal claw fossa, two weakly plumose setae on distal claw fossa) and two parambulacral setae (one fine euphathidium on posterior surface, one scaliform proeuphathidium on anterior surface).

Remarks

Among Isobactrus species, only I. magnus (Lohmann, 1907) has so far been known to possess a distinct hook on the claw shaft. I. hamatus shares this characteristics, but is easily discernible from I. magnus by the unfused anterior epimeral plate, and the absence of bipectinate setae on all legs.

The present species is described on the basis of one single male specimen collected from the Oshoro Bay in which the most intensive collection was executed during the study. Therefore, it is possible that this species actually has more wide distributional range, and a limited occurrence of this species is due to low frequency of sampling.

The specific epithet is derived from the hook on the claw shaft.

Habitat - Intertidal zone: Algae - Sargassum thunbergii on flat.

Distribution in Hokkaido-Oshoro.

Isobactrus latistriatus sp. nov.

[Japanese name: Futojima-ojigidani]

(Figs. 15-18)

Type series. Holotype: Female, Fucus evanescens on flat, intertidal, Utoro, Okhotsk coast of Hokkaido, 6.vi.1988, H. Abé coll. Allotype: Male, data same as the holotype. Paratypes: 2 males, data same as the holotype; 2 tritonymphs, on Gloiopeltis furcata at shore line, intertidal, Yakumo, Pacific coast of Hokkaido, 10.xi.1993, Y. Takashima coll.

Female (holotype)

Idiosoma $388 \mu \mathrm{m}$ long, $272 \mu \mathrm{m}$ wide. Color in life dark green with a fine dorsal semitransparent line longitudinally.

Dorsum (Fig. 15A): Dorsal plate ornamented with weak panels (Fig. 15D), and partly with fine canaliculi. Dorsal membranous cuticle (Fig. 15C) widely striated, not tuberculate, furnished with three pairs of subsurface pores between $\mathrm{AD}$ and $\mathrm{PD}$. $\mathrm{AD}$ and $\mathrm{PD}$ separated by interval more than $\mathrm{AD}$-length. $\mathrm{AD} 106 \mu \mathrm{m}$ long, $92 \mu \mathrm{m}$ wide, concave posteriorly, ornamented with clear areolation and a pair of dorsal pores laterally. OC $42 \mu \mathrm{m}$ long, furnished with one large cornea and two tiny polygonal pores. PD $166 \mu \mathrm{m}$ long, $134 \mu \mathrm{m}$ wide, furnished with a pair of small dorsal pores posteriorly. Costae not clear.

Chaetotaxy of dorsal region: Dorsal setae very short and faint except for ds-iii. Setae ds-i on $\mathrm{AD}$; ds-ii each placed on membranous cuticle between $\mathrm{AD}$ and $\mathrm{OC}$; ds-iii long and thick, each on membranous cuticle between $\mathrm{AD}$ and $\mathrm{PD}$; ds-iv and ds-v on PD.

Venter (Fig. 15B) : Epimeral plates weakly developed only on each coxal region. Ventral membranous cuticle more finely striated than that of dorsum. Epimeral region furnished with several subsurface pores medially, and with epimeral pore between insertions of leg I and leg II on each side.

Chaetotaxy of epimeral region: Epimeral setae placed on striated membranous cuticle except for pes-iii-lat. Setae aes-i located at level posteriorly to camerostome; aes-ii-lat placed at posterior to insertion of leg II ; aes-ii-v placed most medially ; pes-iii-lat placed dorsally on posterior epimeral plate of coxae III ; pes-iii-v near medial margins of coxae III ; pes-iv placed near coxae IV.

Genitoanal region (Fig. 16A): Genitoanal region surrounded with striated membranous cuticle. Genital foramen $64 \mu \mathrm{m}$ long, $36 \mu \mathrm{m}$ wide, occupying from level of the insertion of leg 

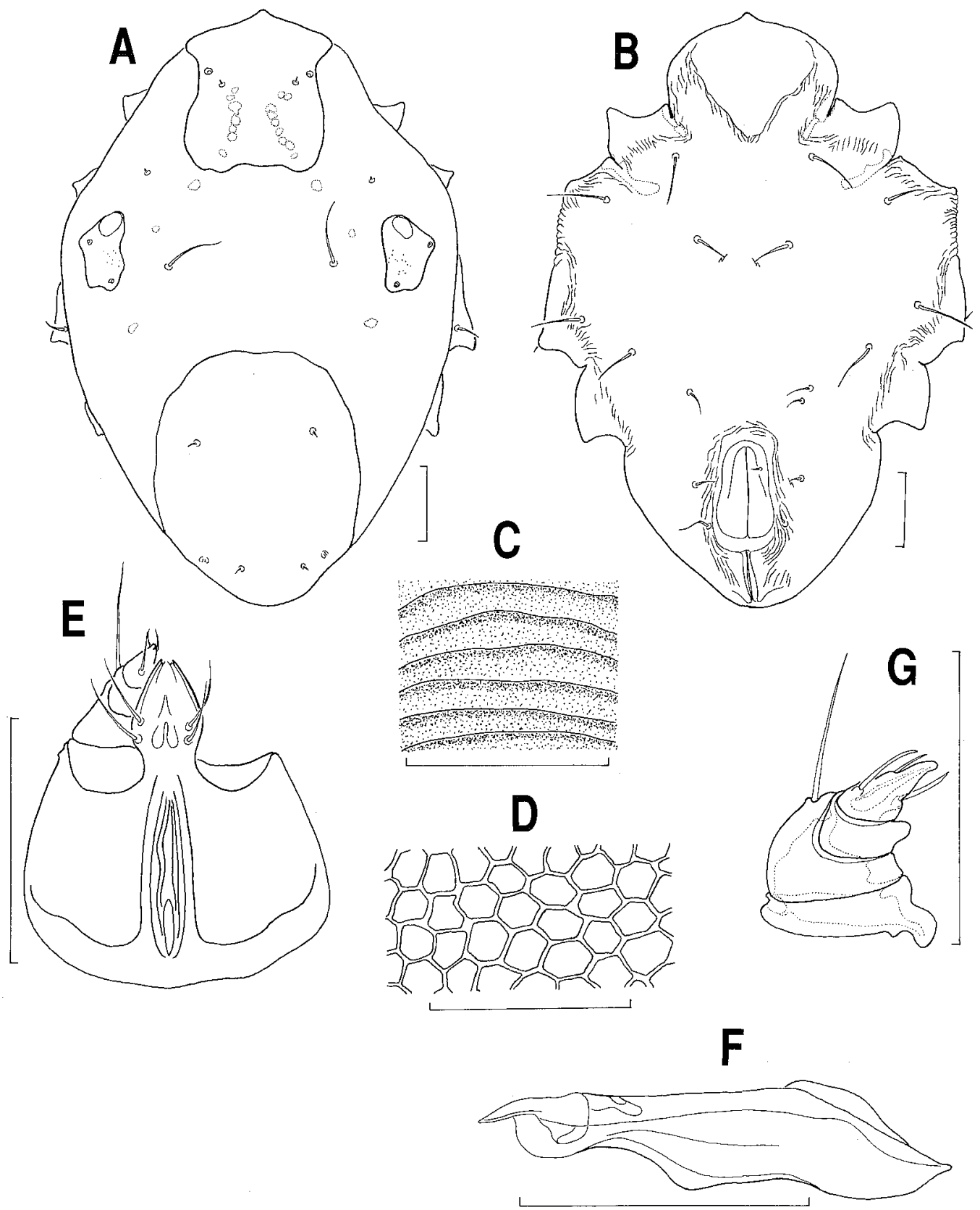

Fig. 15. Isobactrus latistriatus sp. nov., female (holotype). A, idiosoma (Ds); B, idiosoma (Vr) ; C, striation of membranous cuticle (Ds) ; D, panels on PD ; E, gnathosoma (Vr) (left palp omitted) ; F, chelicera (L); G, palp (L). Scale bars $=50 \mu \mathrm{m}$.

IV to level anterior to anal foramen. Genital sclerites band-like. One pair of very short, and two pairs of large internal genital acetabula are visible. Anal foramen placed subterminally on membranous cuticle.

Chaetotaxy of genitoanal region: Three filiform perigenital setae located on each side of 


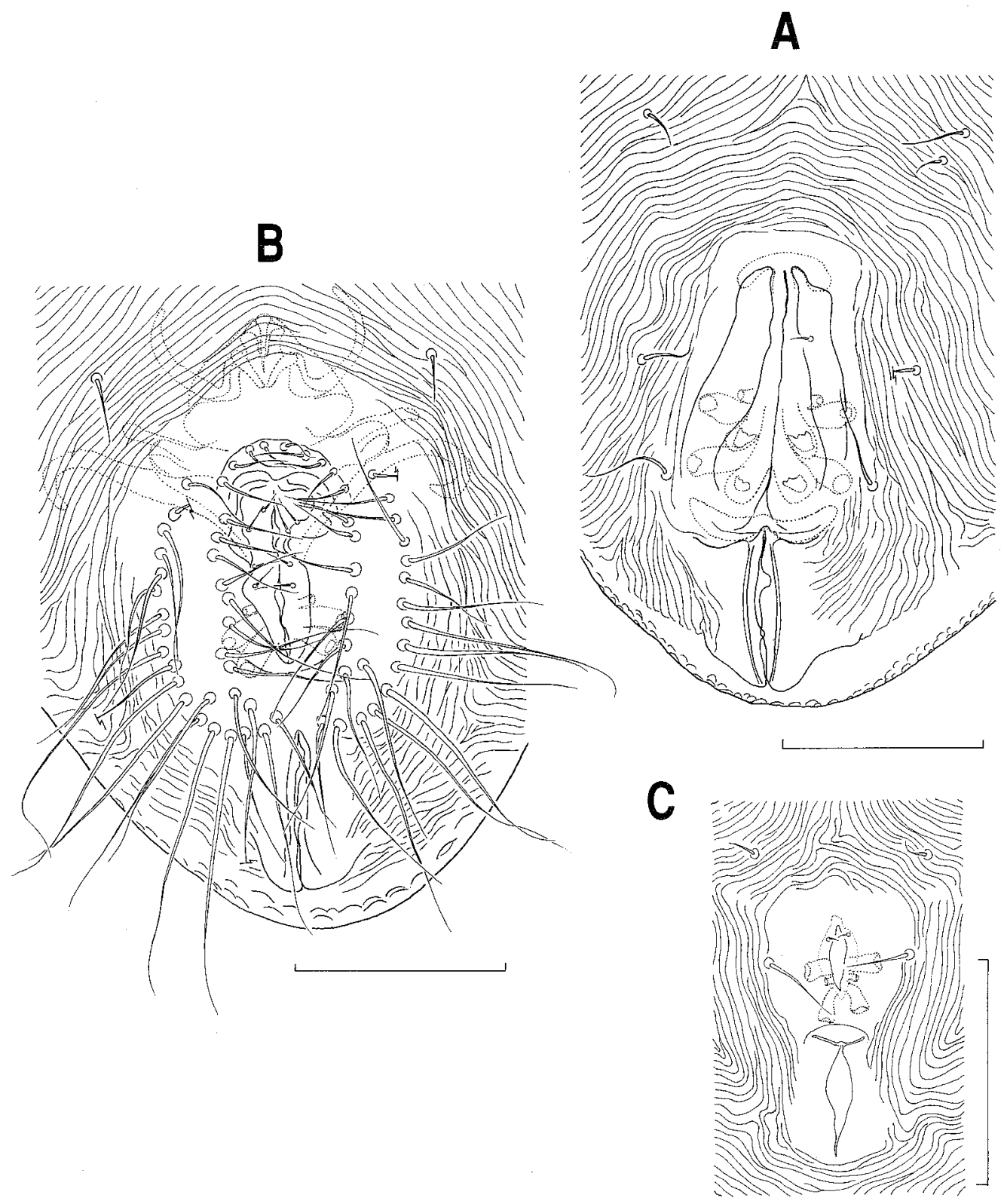

Fig. 16. Isobactrus latistriatus sp. nov., genitoanal regions. A, female (holotype); B, male (allotype) ; C, tritonymph (paratype). Scale bars $=50 \mu \mathrm{m}$.

genital foramen as arranged in Fig. 16A. The described specimen has one additional perigenital seta on the left side of genital foramen. Subgenital seta short filiform ; only one seta is visible on the left genital sclerite.

Gnathosoma (Fig. 15E) : $66 \mu \mathrm{m}$ long, $62 \mu \mathrm{m}$ wide, gnathosoma-length/idiosoma-length 0 . 17. Base, length/width 0.64 . Rostrum $30 \mu \mathrm{m}$ long, nearly lanceolate, not reaching to level of distal end of palp. Rostral setae two pairs, at swollen point, both long and thick. Chelicera 

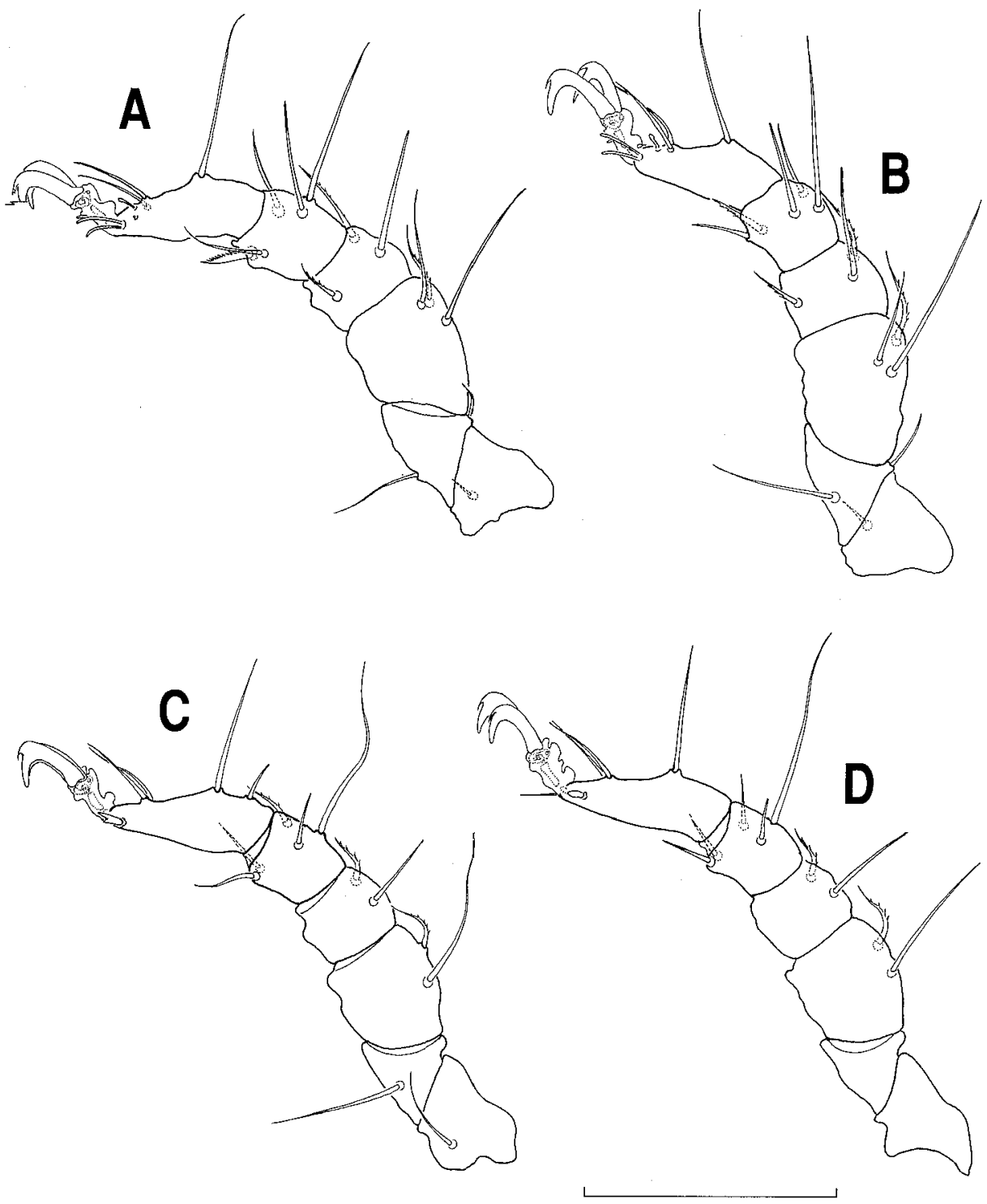

Fig. 17. Isobactrus latistriatus sp. nov., female (holotype). A, leg I (L); B, leg II (L) ; C, leg III (R) ; D, leg IV (R). Scale bar $=100 \mu \mathrm{m}$.

(Fig. 15F) with basal segment $60 \mu \mathrm{m}$ long, and movable digit $18 \mu \mathrm{m}$ long, without distinct denticulation along dorsal edge. Fixed digit weakly developed. Palp (Fig. 15G) $42 \mu \mathrm{m}$ long; $\mathrm{P}-1$ short and cylindrical ; $\mathrm{P}-2$ longest and robust, with a long thick filiform seta distidorsally; P-3 short and cylindrical; $\mathrm{P}-4$ conical, with two thick and one fine filiform setae intermediately, and with two appressed blunt spiniform projections terminally.

Legs (Figs. 17A-D) : Length of legs I, II, III, IV =214, 214, 208, $208 \mu \mathrm{m}$ respectively. Ornamentation indistinct. Lateral claw with four to six fine accessory teeth.

Leg chaetotaxy as follows: Trochanters I-IV, 1-1-1-0; basifemora I-IV, 2-2-1-0; telofemora I-IV, 3-3-2-2; genua I-IV, 3-3-2-2; tibiae I-IV, 5-5-5-5. As for large 

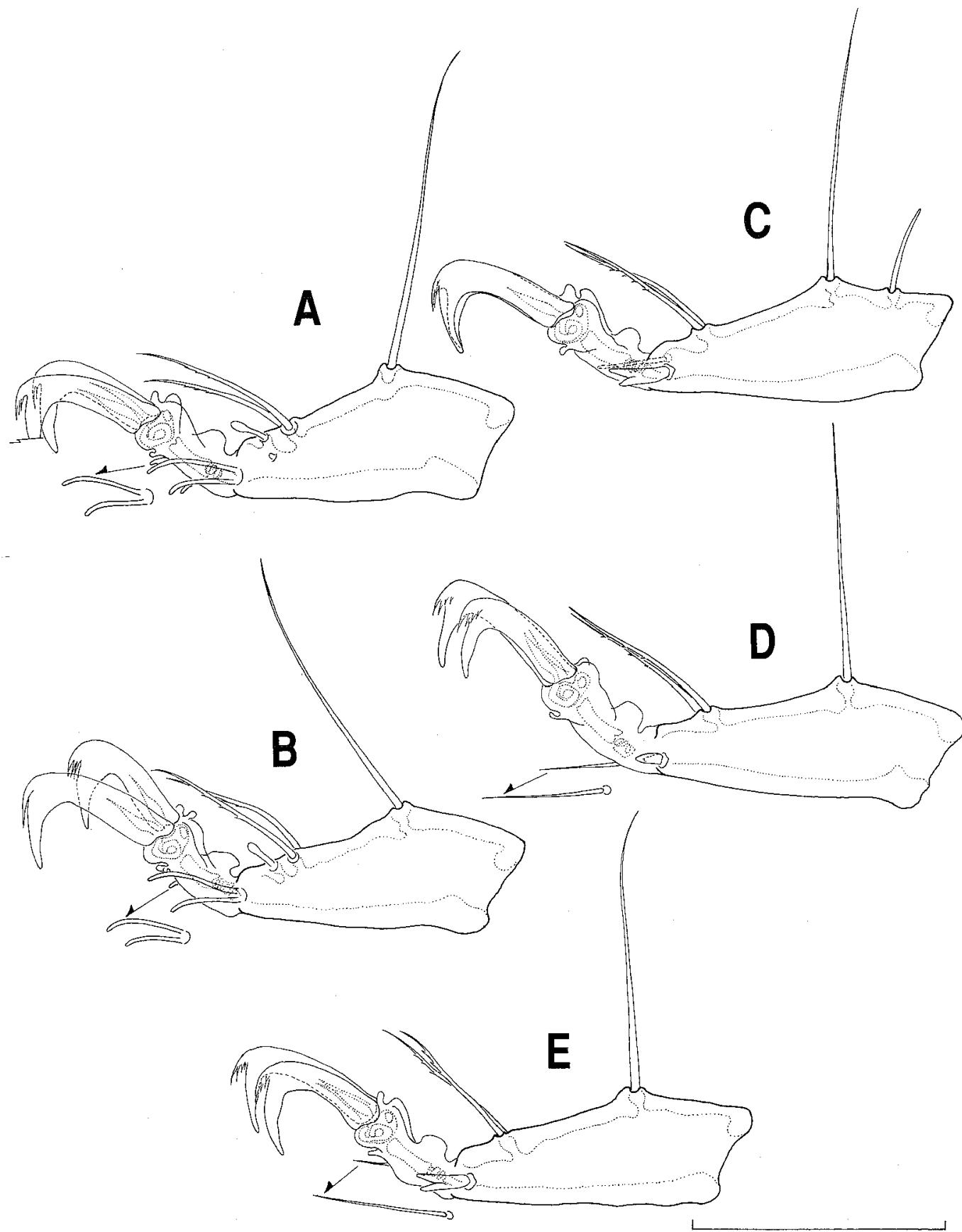

Fig. 18. Isobactrus latistriatus sp. nov., female (holotype). A, tarsus I (L); B, tarsus II (L) ; C, tarsus III (R) ; D, tarsus IV (R). Male (allotype). E, tarsus IV (R). Scale bar $=50 \mu \mathrm{m}$. 
bipectinate setae: Tibiae I-IV, 1-0-0-0. Tarsus I (Fig. 18A) with three dorsal setae, one solenidion, one vestigial famulus, and four parambulacral setae (paired doublet euphathidia). Solenidion clavate on posterodorsal surface of claw fossa. Famulus very faint at just ventrally to solenidion. Tarsus II (Fig. 18B) with three dorsal setae, one solenidion, and four parambulacral setae. Solenidion clavate on posterodorsal surface of claw fossa. Tarsus III (Fig. 18C) with four dorsal setae and two parambulacral setae (one single euphathidium on posterior surface, one divaricate proeuphathidium on anterior surface). Tarsus IV (Fig. 18D) with three dorsal setae (one filiform seta on basal claw fossa, two weakly plumose setae on distal claw fossa) and two parambulacral setae (one fine euphathidium on posterior surface, one divaricate proeuphathidium on anterior surface).

Male (allotype).

Idiosoma $360 \mu \mathrm{m}$ long, $240 \mu \mathrm{m}$ wide, gnathosoma-length/idiosoma-length 0.17 , resembling the female in essential respects except for character states of genitoanal region.

Genitoanal region (Fig. 16B) furnished with long filiform 64 perigenital setae as arranged in Fig. 16B. Membranous cuticle weakly sclerotized around genital foramen. Genital foramen $46 \mu \mathrm{m}$ long, $26 \mu \mathrm{m}$ wide. Subgenital setae four pairs on genital sclerites, arranged 2-2. Genital acetabula two pairs. Spermatophorotype (cf. Fig. 16B) $74 \mu \mathrm{m}$ long, $70 \mu \mathrm{m}$ wide, massive and rhombic.

Tarsus IV (Fig. 18E) similar to that in the female.

Tritonymph (paratype).

Idiosoma $256 \mu \mathrm{m}$ long, $164 \mu \mathrm{m}$ wide, gnathosoma-length/idiosoma-length 0.20 .

Dorsum : $\mathrm{AD} 84 \mu \mathrm{m}$ long, $70 \mu \mathrm{m}$ wide, faintly concave posteriorly. PD $120 \mu \mathrm{m}$ long, 100 $\mu \mathrm{m}$ wide, convex anteriorly. $\mathrm{AD}$ and $\mathrm{PD}$ separated by interval about a half of $\mathrm{PD}-$ width. $\mathrm{OC}$ $34 \mu \mathrm{m}$ long. A pair of subsurface pore placed between $\mathrm{AD}$ and $\mathrm{OC}$. Two pairs of subsurface pores located between $\mathrm{AD}$ and $\mathrm{PD}$.

Venter : Epimeral plate developed only on each coxal region. Epimeral region furnished with several subsurface pores medially.

Genitoanal region (Fig. 16C) : Genital region furnished with two pairs of perigenital and one pair of faint subgenital setae. Primordial genital slit surrounded by weakly sclerotized membranous cuticle, furnished with three pairs of internal genital acetabula of which second pair is very short. Anal foramen ventrally placed on membranous cuticle.

Legs: Length of legs I, II, III, IV $=132,122,130,130 \mu \mathrm{m}$ respectively. Leg chaetotaxy of trochanters I-IV, 1-1-1-0; basifemora I-IV, 2-2-1-0 ; telofemora I-IV, 3-3-2-2 ; genua I-IV, 3-3-3-2 ; tibiae I-IV, 5-5-5-5. Distinct bipectinate setae on tibiae I-IV, 1-0-0-0.

Morphological variation and abnormality

The size range of the idiosoma, gnathosoma, and legs I-IV as follows.

Male $(\mathrm{n}=3)$. Idiosoma-length : $356-392 \mu \mathrm{m}$, -width : $224-252 \mu \mathrm{m}$; gnathosoma-length: 62-66 $\mu \mathrm{m}$, -width : 60-64 $\mu \mathrm{m}$; leg-length : Leg I, 192-214 $\mu \mathrm{m}$; leg II, 186-214 $\mu \mathrm{m}$; leg III, 188 $-212 \mu \mathrm{m}$; leg IV, 194-214 $\mu \mathrm{m}$.

Tritonymph $(\mathrm{n}=2)$. Idiosoma-length : 256-304 $\mu \mathrm{m}$, -width : 164-204 $\mu \mathrm{m}$; gnathosomalength: $50 \mu \mathrm{m}$, -width : 56-58 $\mu \mathrm{m}$; leg-length: Leg I, 132-134 $\mu \mathrm{m}$; leg II, 122-138 $\mu \mathrm{m}$; leg III, $130-140 \mu \mathrm{m}$; leg IV, $130-140 \mu \mathrm{m}$.

The number of the perigenital setae varies from 64 to 74 in the male. The holotype female specimen has one additional perigenital seta on the left side of genital foramen.

Remarks

Isobactrus latistriatus is characterized by having widely striated dorsal membranous cuticle. In this respect, the present species shows close similarity to $I$. dentatus, but it is readily discriminated from the latter by having the accessory process with four to six fine 
teeth. I. latistriatus also resembles I. hartmanni Bartsch, 1972 in the idiosomal and leg chaetotaxy, and morphology of accessory process, however the new species differs from the latter in the outline of dorsal plates, and the less number of (64-74) perigenital setae in the male.

The specific epithet is derived from the widely striated membranous cuticle on dorsal surface.

Habitat-Intertidal zone: Algae - Fucus evanescens on flat, Gloiopeltis furcata on shore line.

Distribution in Hokkaido-Yakumo, Kushiro, Aininkappu, Utoro.

Isobactrus tuberculatus sp. nov.

[Japanese name: Kobu-ojigidani]

(Figs. 19-23)

Type series. Holotype: Female, Enteromorpha intestinalis on gravels at a depth of $0.1 \mathrm{~m}$, Shizunai, Pacific coast of Hokkaido, 22.vii.1992, H. Abe coll. Allotype: Male, locality same as the holotype, 22.v.1989, H. Abé coll. Paratypes: 2 females, 1 male, 2 tritonymphs and 1 protonymph, data same as the allotype; 1 female and 1 deutonymph, data same as the holotype.

Female (holotype)

Idiosoma $348 \mu \mathrm{m}, 232 \mu \mathrm{m}$ wide. Color in life dark green with a fine dorsal semitransparent line longitudinally.

Dorsum (Fig. 19A) : Dorsal plate ornamented with reticulated panels (Fig. 19D), and partly with fine canaliculi. Dorsal membranous cuticle (Fig. 19C) tuberculate, furnished with two pairs of subsurface pores between $A D$ and $P D$. $A D$ and $P D$ separated by interval of approximately a half of AD-length. AD $116 \mu \mathrm{m}$ long, $124 \mu \mathrm{m}$ wide, weakly concave posteriorly, ornamented with areolation posteriorly, and with a pair of dorsal pores anteriorly. OC 68 $\mu \mathrm{m}$ long, furnished with one large cornea and two tiny polygonal pores. Areolation indistinct. PD $178 \mu \mathrm{m}$ long, $142 \mu \mathrm{m}$ wide, furnished with a pair of small dorsal pores on posteriorly. Costae not seen.

Chaetotaxy of dorsal region: Dorsal setae very short and faint except for ds-iii. Setae ds-i on $\mathrm{AD}$; ds-ii each placed on membranous cuticle between $\mathrm{AD}$ and $\mathrm{OC}$; ds-iii long and thick, each on membranous cuticle between AD and PD; ds-iv and ds-v on PD.

Venter (Fig. 19B): Epimeral plates weakly developed only on each coxal region. Epimeral region furnished with several subsurface pores medially, and with epimeral pore between insertions of leg I and leg II on each side.

Chaetotaxy of epimeral region: Epimeral setae placed on striated membranous cuticle except for pes-iii-lat. Setae aes-i located at level posteriorly to camerostome; aes-ii-lat placed at posterior to insertion of leg II ; aes-ii-v placed most medially ; pes-iii-lat placed dorsally on epimeral plate of coxae III ; pes-iii-v near medial margins of coxae III ; pes-iv placed near coxae IV.

Genitoanal region (Fig. 20A) : Genitoanal region surrounded with striated membranous cuticle. Genital foramen $66 \mu \mathrm{m}$ long, $38 \mu \mathrm{m}$ wide, occupying from level anterior to insertion of leg IV to level anterior to anal foramen. Genital sclerites band-like, furnished with one pair of very short, and two pairs of large internal genital acetabula.

Chaetotaxy of genitoanal region: Three filiform perigenital setae located on each side of genital foramen as arranged in Fig. 20A. Subgenital setae short filiform; one pair on genital sclerites, arranged 1-0. Anal foramen placed ventrally on membranous cuticle.

Gnathosoma (Fig. 19E) : $54 \mu \mathrm{m}$ long, $62 \mu \mathrm{m}$ wide, gnathosoma-length/idiosoma-length 0 . 16. Base, length/width 0.55 . Rostrum $24 \mu \mathrm{m}$ long, nearly lanceolate, not reaching to level of distal end of palp. Rostral setae two pairs, at swollen point, both long and thick. Chelicera 


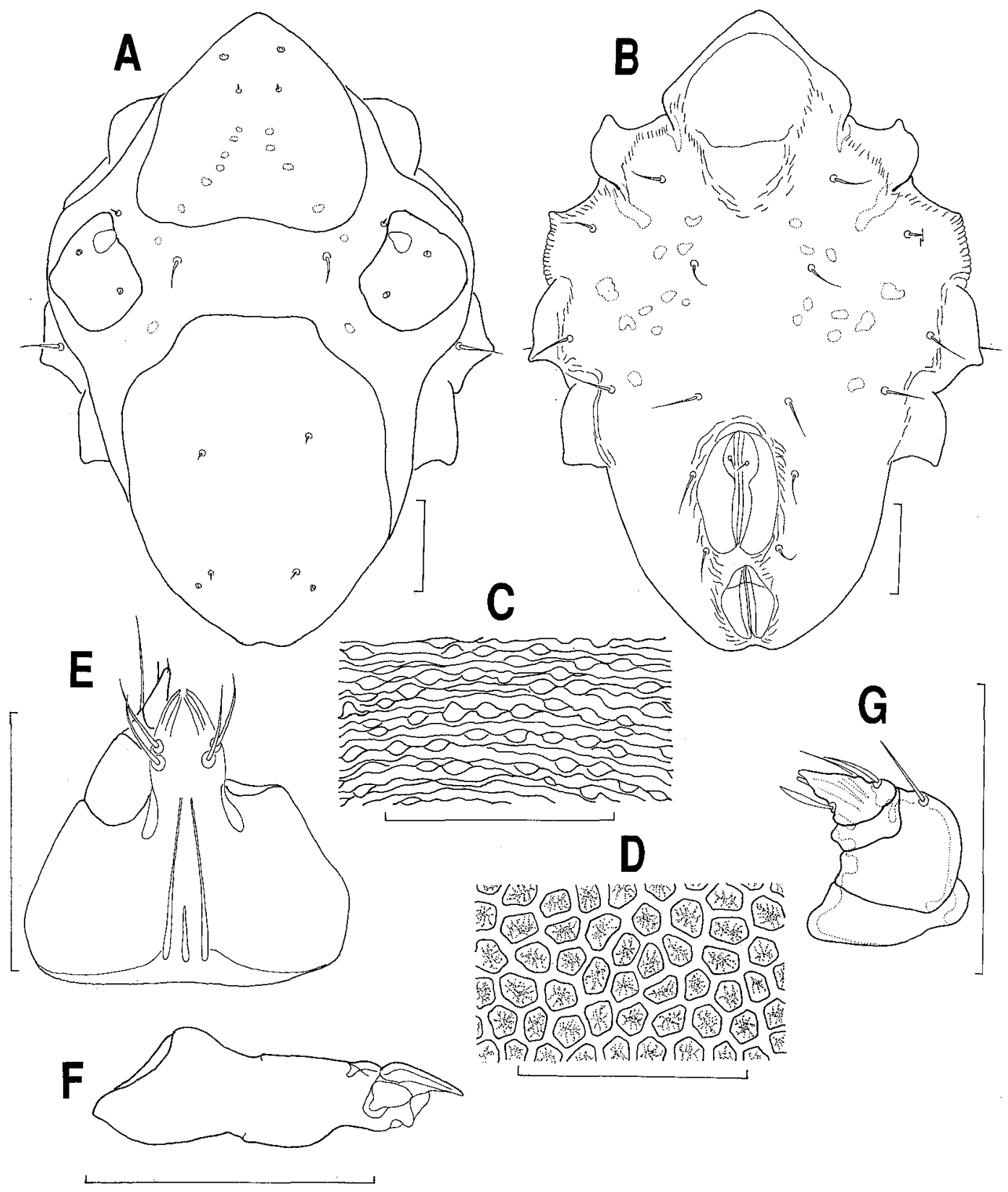

Fig. 19. Isobactrus tuberculatus sp. nov., female (holotype). A, idiosoma (Ds) ; B, idiosoma (Vr); C, striation of membranous cuticle (Ds) ; D, panels on PD ; E, gnathosoma (Vr) (left palp omitted) ; F, chelicera (R); G, palp (L). Scale bars $=50 \mu \mathrm{m}$.

(Fig. 19F) with basal segment $48 \mu \mathrm{m}$ long, and movable digit $16 \mu \mathrm{m}$ long, without distinct denticulation along dorsal edge. Fixed digit weakly developed. Palp (Fig. 19G) $38 \mu \mathrm{m}$ long; P-1 short and cylindrical ; P-2 longest and robust, with a thick filiform seta distidorsally ; $\mathrm{P}$ -3 short and cylindrical; $\mathrm{P}-4$ conical, with two blade-like and one fine filiform setae inter- 


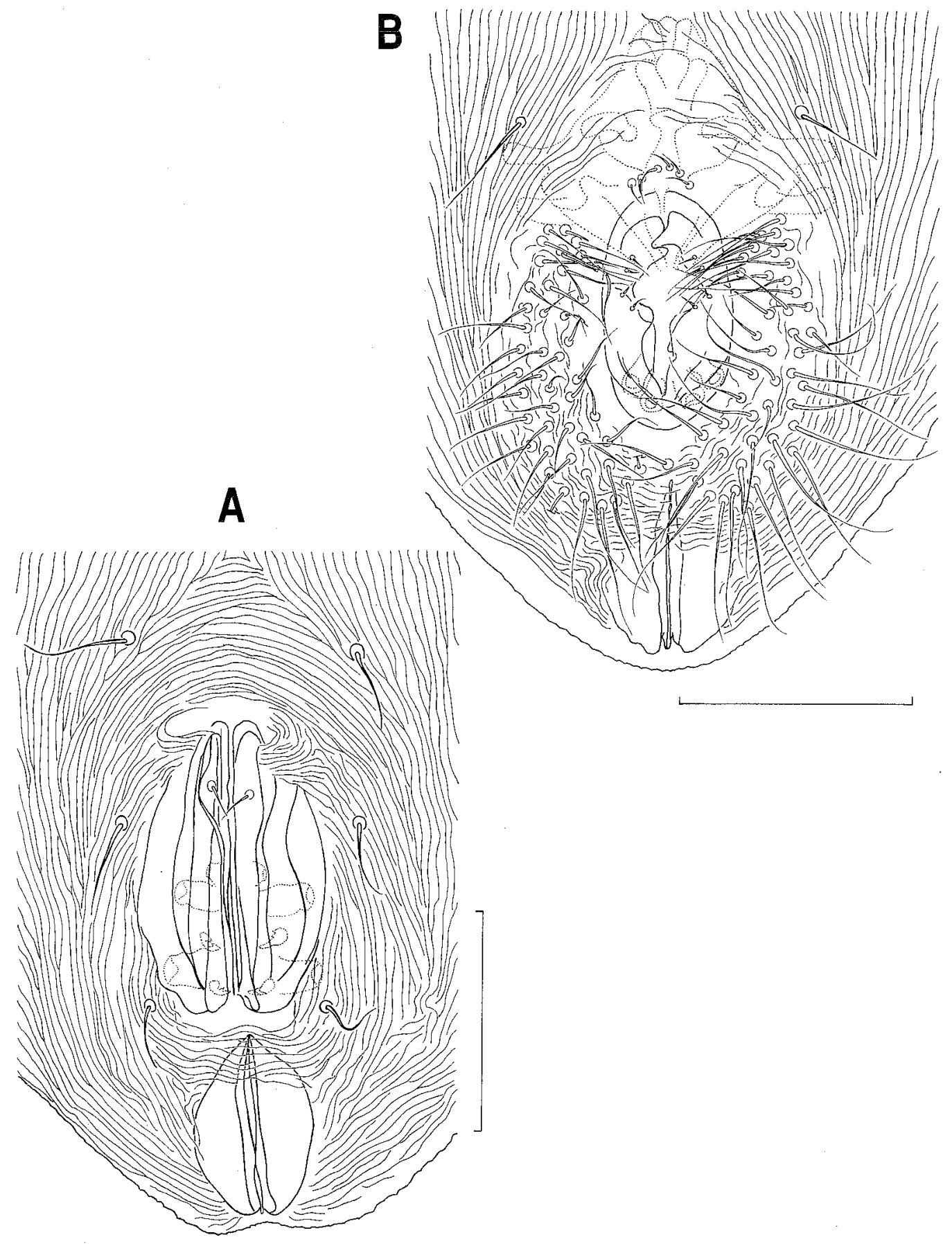

Fig. 20. Isobactrus tuberculatus sp. nov., genitoanal regions. A, female (holotype); B, male (allotype). Scale bars $=50 \mu \mathrm{m}$. 


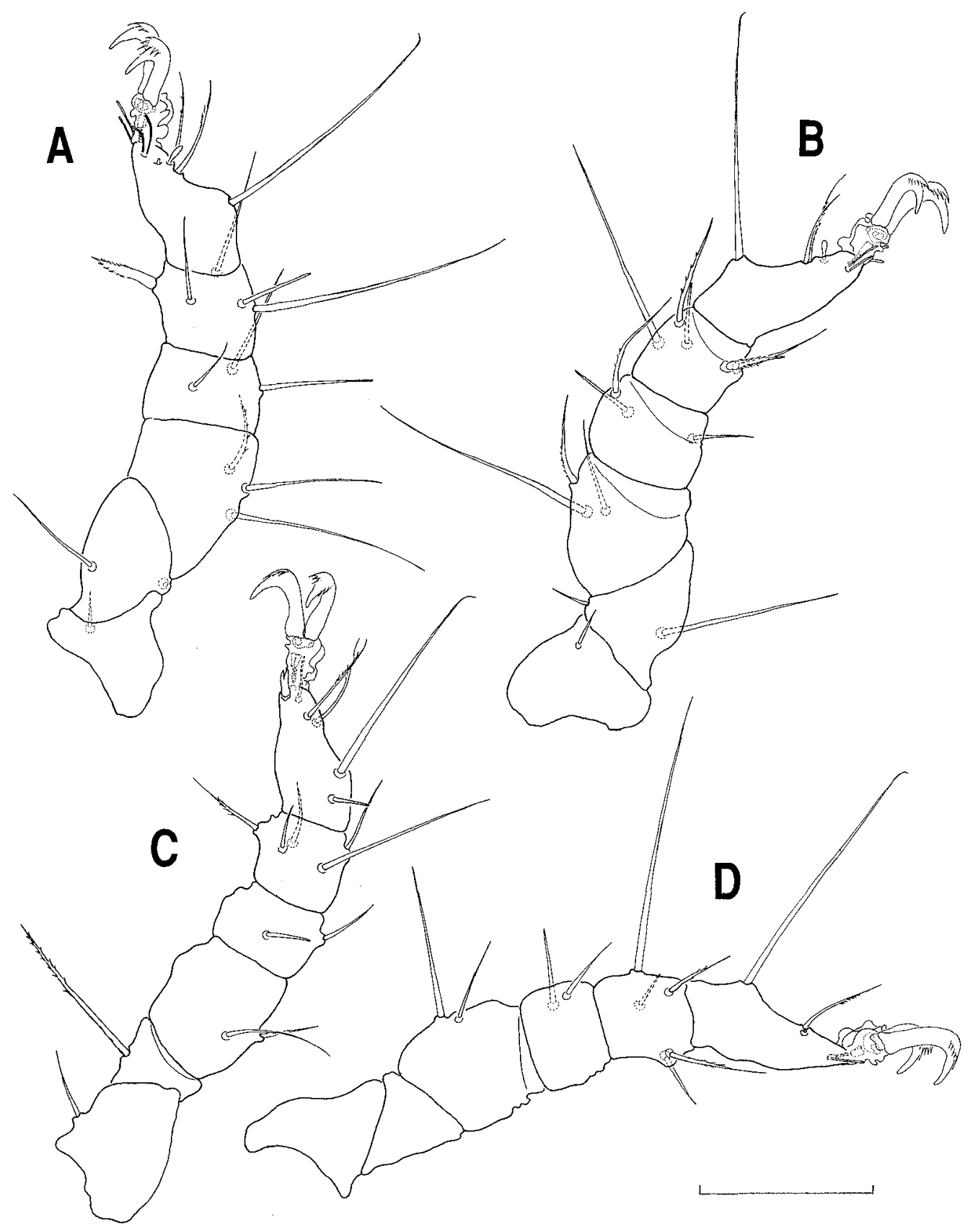

Fig. 21. Isobactrus tuberculatus sp. nov., female (holotype). A, leg I (L); B, leg II (L); C, leg III (R); D, leg IV (R). Scale bar $=100 \mu \mathrm{m}$.

mediately, and with two appressed blunt spiniform projections terminally.

Legs (Figs. 21A-D) : Length of legs I, II, III, IV $=182,172,166,166 \mu \mathrm{m}$ respectively. Ornamentation indistinct. Lateral claw with palmate accessory process, bearing six to eight delicate teeth. 


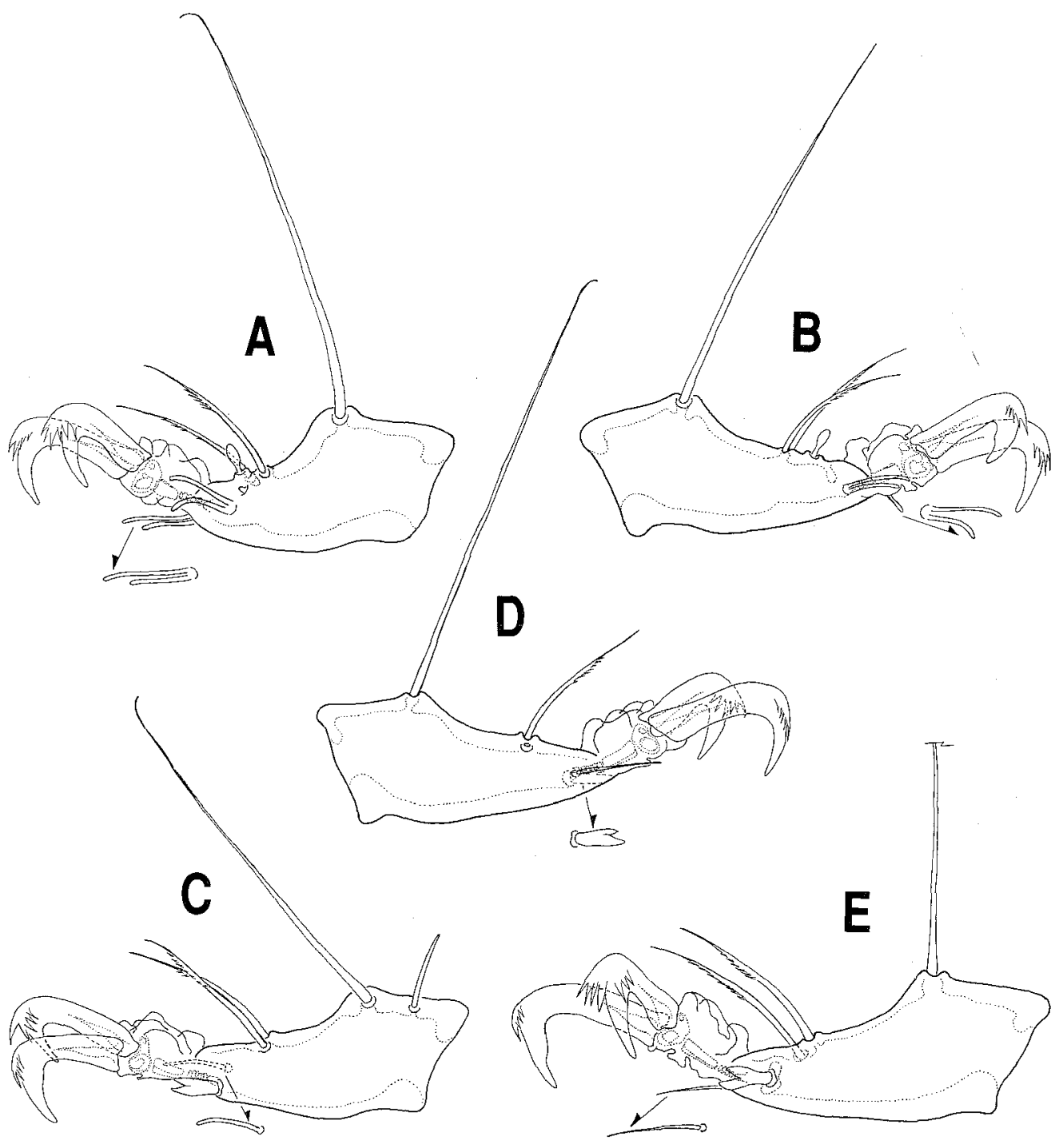

Fig. 22. Isobactrus tuberculatus sp. nov., female (holotype). A, tarsus I (L); B, tarsus II (L) ; C, tarsus III (R) ; D, tarsus IV (R). Male (allotype). E, tarsus IV (R). Scale bar $=50 \mu \mathrm{m}$.

Leg chatotaxy as follows: Trochanters I-IV, 1-1-1-0; basifemora I-IV, 2-2-1-0 ; telofemora I-IV, 3-3-2-2; genua I-IV, 3-3-2-2; tibiae I-IV, 5-5-5-5. As for large bipectinate setae: Tibiae I-IV, 1-0-0-0. Tarsus I (Fig. 22A) with three dorsal setae, one solenidion, one vestigial famulus, and four parambulacral setae (paired doublet euphathidia). Solenidion clavate on posterodorsal surface of claw fossa. Famulus faint papilliform at just ventrally to solenidion. Tarsus II (Fig. 22B) with three dorsal setae, one solenidion, and four parambulacral setae. Solenidion clavate on posterodorsal surface of claw fossa. Tarsus III (Fig. 22C) with four dorsal setae and two parambulacral setae (one single euphathidium on posterior surface, one divaricate proeuphathidium on anterior surface). Tarsus IV (Fig. 22D) 

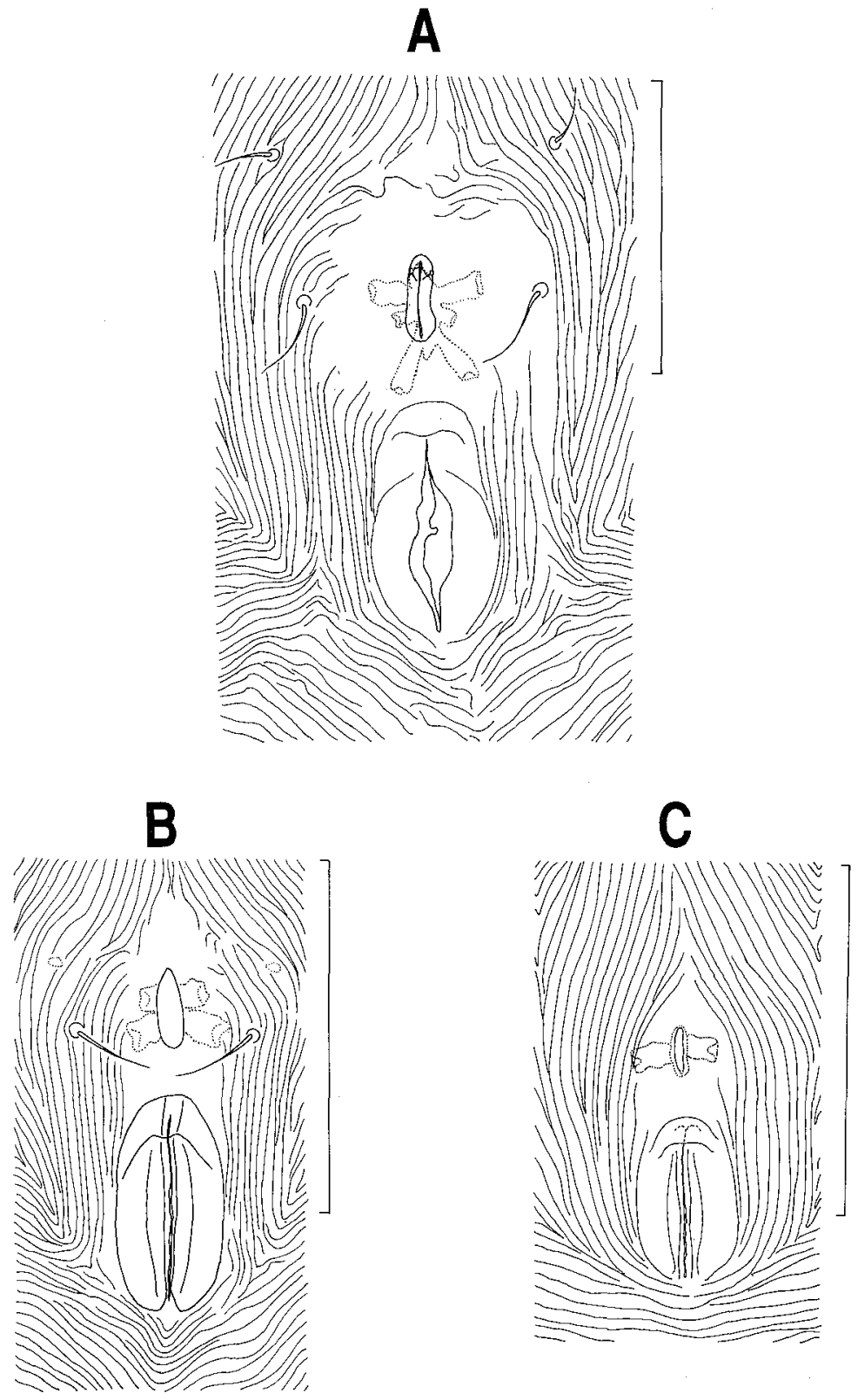

Fig. 23. Isobactrus tuberculatus sp. nov., genitoanal regions. A, tritonymph (paratype); B, deutonymph (paratype); C, protonymph (paratype). Scale bars $=50 \mu \mathrm{m}$.

with three dorsal setae (one terminally bending filiform seta on basal claw fossa, two weakly plumose setae on distal claw fossa) and two parambulacral setae (one fine euphathidium on posterior surface, one divaricate proeuphathidium on anterior surface).

Male (allotype) 
Idiosoma $328 \mu \mathrm{m}$ long, $236 \mu \mathrm{m}$ wide, gnathosoma-length/idiosoma-length 0.18 , resembling the female in essential respects except for character states of genitoanal region.

Genitoanal region (Fig. 20B) furnished with long filiform 98 perigenital setae as arranged in Fig. 20B. Membranous cuticle weakly sclerotized around genital foramen. Genital foramen $50 \mu \mathrm{m}$ long, $28 \mu \mathrm{m}$ wide. Subgenital setae four pairs on genital sclerites, arranged 2-2. Genital acetabula two pairs. Spermatophorotype (cf. Fig. 20B) $68 \mu \mathrm{m}$ long, $70 \mu \mathrm{m}$ wide, massive and rhombic.

Tarsus IV (Fig. 22E) resembles that in the female.

\section{Tritonymph (paratype)}

Idiosoma $268 \mu \mathrm{m}$ long, $180 \mu \mathrm{m}$ wide, gnathosoma-length/idiosoma-length 0.18 .

Dorsum : AD $104 \mu \mathrm{m}$ long, $96 \mu \mathrm{m}$ wide, faintly concave posteriorly. PD $154 \mu \mathrm{m}$ long, 112 $\mu \mathrm{m}$ wide, convex anteriorly. $\mathrm{AD}$ and $\mathrm{PD}$ separated by interval about a half of $\mathrm{PD}$-length. $\mathrm{OC}$ $54 \mu \mathrm{m}$ long. Two pairs of subsurface pores located between AD and PD.

Venter : Epimeral plate developed only on each coxal region. Epimeral region furnished with several subsurface pores medially.

Genitoanal region (Fig. 23A) : Genital region furnished with two pairs of perigenital and one pair of faint subgenital setae. Primordial genital slit surrounded by weakly sclerotized membranous cuticle, furnished with three pairs of internal genital acetabula of which second pair is very short. Anal foramen ventrally placed on membranous cuticle.

Legs: Length of legs I, II, III, IV $=126,128,122,126 \mu \mathrm{m}$ respectively. Leg chaetotaxy of trochanters I-IV, 1-1-1-0; basifemora I-IV, 2-2-1-0 ; telofemora I-IV, 3-3-2-2 ; genua I-IV, 3-3-2-2 ; tibiae I-IV, 5-5-5-5. Distinct bipectinate setae on tibiae I-IV, $1-0-0-0$.

Deutonymph (paratype)

Idiosoma $224 \mu \mathrm{m}$ long, $140 \mu \mathrm{m}$ wide, gnathosoma-length/idiosoma-length 0.20 .

Dorsum: AD $92 \mu \mathrm{m}$ long, $74 \mu \mathrm{m}$ wide, faintly concave posteriorly. PD $110 \mu \mathrm{m}$ long, 90 $\mu \mathrm{m}$ wide, convex anteriorly. $\mathrm{AD}$ and $\mathrm{PD}$ separated by interval approximately one fourth of $\mathrm{AD}$-length. OC $40 \mu \mathrm{m}$ long. Two pairs of subsurface pores located between $\mathrm{AD}$ and PD.

Venter : Epimeral plate developed only on each coxal region. Epimeral region furnished with several subsurface pores medially.

Genitoanal region (Fig. 23B): Genital region furnished with one pair of perigenital setae, bearing a tiny subsurface pore on each lateral region. Primordial genital slit surrounded by faintly sclerotized membranous cuticle, furnished with two pairs of internal genital acetabula.

Legs : Length of legs I, II, III, IV $=106,110,110,112 \mu \mathrm{m}$ respectively. Leg chaetotaxy of trochanters I-IV , 1-1-1-0; basifemora I-IV, 2-2-1-0 ; telofemora I-IV, 3-3-2-2 ; genua I -IV , 3-3-2-2; tibiae I-IV, $5-5-5-5$. Distinct bipectinate setae on tibiae I-IV, $1-0-0-0$.

Protonymph (paratype)

Idiosoma $200 \mu \mathrm{m}$ long, $132 \mu \mathrm{m}$ wide, gnathosoma-length/idiosoma-length 0.17 .

Dorsum : AD $68 \mu \mathrm{m}$ long, $54 \mu \mathrm{m}$ wide, faintly concave posteriorly. PD $76 \mu \mathrm{m}$ long, $56 \mu \mathrm{m}$ wide, convex anteriorly. $\mathrm{AD}$ and $\mathrm{PD}$ separated by interval about $\mathrm{AD}-$ length. $\mathrm{OC} 38 \mu \mathrm{m}$ long. Two pairs of subsurface pores located between $\mathrm{AD}$ and $\mathrm{PD}$.

Venter : Epimeral plate developed only on each coxal region. Epimeral region furnished with several subsurface pores medially.

Genitoanal region (Fig. 23C) : Genital region without genital setae. Primordial genital slit surrounded by faintly sclerotized membranous cuticle, furnished with one pair of internal genital acetabula.

Legs : Length of legs I, II, III, IV $=94,96,90,84 \mu \mathrm{m}$ respectively. Leg chaetotaxy of trochanters I-IV, 1-1-1-0; basifemora (femur of leg IV) I-IV, 2-2-1-2 ; telofemora I-III, 33-2 ; genua I-IV, 3-3-2-2 ; tibiae I-IV, 5-5-5-5. Distinct bipectinate setae on tibiae I-IV, 1- 
$0-0-0$.

Morphological variation and abnormality

The size range of the idiosoma, gnathosoma, and legs I-IV as follows.

Female $(\mathrm{n}=4)$. Idiosoma-length : $324-352 \mu \mathrm{m}$, -width : 228-236 $\mu \mathrm{m}$; gnathosoma-length : 54-62 $\mu \mathrm{m}$, -width : $62-64 \mu \mathrm{m}$; leg-length : Leg I, 178-184 $\mu \mathrm{m}$; leg II, 172-182 $\mu \mathrm{m}$; leg III, 162 $-178 \mu \mathrm{m}$; leg IV, $166-170 \mu \mathrm{m}$.

Male ( $\mathrm{n}=2$ ). Idiosoma-length : $328-340 \mu \mathrm{m}$, -width : $236-240 \mu \mathrm{m}$; gnathosoma-length : 56-58 $\mu \mathrm{m}$, -width : $64-68 \mu \mathrm{m}$; leg-length : Leg I, 168-180 $\mu \mathrm{m}$; leg II, 176-178 $\mu \mathrm{m}$; leg III, 168 $-170 \mu \mathrm{m}$; leg IV, 162-172 $\mu \mathrm{m}$.

Tritonymph $(\mathrm{n}=2)$. Idiosoma-length : 268-292 $\mu \mathrm{m}$, -width : 180-204 $\mu \mathrm{m}$; gnathosomalength : $48-50 \mu \mathrm{m}$, -width : 50-58 $\mu \mathrm{m}$; leg-length: Leg I, 168-180 $\mu \mathrm{m}$; leg II, $176-178 \mu \mathrm{m}$; leg III, $168-170 \mu \mathrm{m}$; leg IV, $162-172 \mu \mathrm{m}$.

The leg chaetotaxy varies among adult specimens $(\mathrm{n}=6)$ as follows: Trochanters I-IV, 1-1-1-0 ; basifemora I-IV, 2-2-1-0; telofemora I-IV, 3-3-(1,2)-2; genua I-IV, 3-3-2-2 ; tibiae I-IV, $(4,5)-(3,4,5)-5-5$.

The number of the perigenital setae varies from 97 to 98 in the male.

Remarks

Isobactrus tuberculatus is easily discernible from the congeners by the combination of the following character states: 1) tuberculate dorsal membranous cuticle, 2) posterior dorsal plate with two dorsal setae, 3 ) accessory process palmate with six to eight delicate teeth.

I. tuberculatus is mainly collected at semi-closed shores near the mouths of rivers with a salinity range of about 3-32, and so it probably has tolerance to oligo- and mesohaline brackish water.

The specific epithet is derived from the tuberculate dorsal membranous cuticle.

Habitat-Intertidal zone: Algae - Enteromorpha intestinalis on gravels. Mussels - Mytilus edulis on flat. Coarse sandy sediment.

Distribution in Hokkaido - Oniwaki (Rishiri Island), Date, Shizunai.

\section{Genus Rhombognathus Trouessart, 1888}

[Japanese name: Kaisoudani]

Diagnosis. Ocular plates each with two setae and usually two corneae. Dorsal setae four or five pairs in addition to one pair of adanal setae. Ventral plates often fused into single plate. Anterior and posterior epimeral plates each furnished with 1-3 adjunctive setae. Genital opening of the female ventrally placed. Subgenital setae of the female usually two pairs. Perigenital setae of the male often branched. Tarsus I furnished with bacilliform solenidion and papilliform famulus, and Tarsus II with one bacilliform solenidion. Carpite rod-like. All tarsi with two claws.

\section{Key to species}

1a. Three dorsal setae present on tarsus of the third leg. More than 30 perigenital setae present on each side of genital foramen in the female. ........ tenuiformis sp. nov.

1b. Four dorsal setae present on tarsus of the third leg. Less than 30 perigenital setae present on each side of genital foramen in the female. $\ldots \ldots \ldots \ldots \ldots \ldots \ldots \ldots 2$

2a. One pair of dorsal setae present on posterior dorsal plate. Ventral plates completely

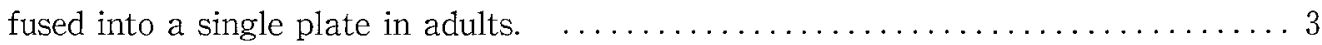

2b. Two pairs of dorsal setae present on posterior dorsal plate. Ventral plates at least partly incised with membranous cuticle, and not completely fused in adults. $\ldots \ldots \ldots .5$ 
3a. Accessory process not typical palmate type, bearing two or three long fine teeth. Rostrum rectangular in form. Posterior dorsal plate uniformly ornamented with reticulated panels, and costae completely absent. ............. teurinus sp. nov.

3b. Accessory process palmate type, and bearing several fine teeth. Rostrum lanceolate in

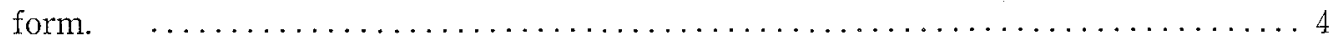

4a. Posterior margin of anterior dorsal plate strongly convex. Posterior dorsal plate ornamented with clear panels. $\ldots \ldots \ldots \ldots \ldots \ldots \ldots \ldots \ldots$ sinensis Bartsch, 1990

4b. Posterior margin of anterior dorsal plate rounded. Posterior dorsal plate ornamented with reticulated panels. $\ldots \ldots \ldots \ldots \ldots \ldots \ldots \ldots \ldots \ldots \ldots \ldots \ldots \ldots \ldots \ldots$ incertus sp. nov.

5a. Genital acetabula two pairs in adults. Five ventral plates, and two pairs of perigenital setae present in the female. Perigenital setae in the male filiform, not branched.

5b. Genital acetabula three pairs in adults Perigenital setae in the male branched. 6

6a. Three plates present on venter in the female. Right and left posterior epimeral, and genital plates fused into a single plate in the female. Two pairs of perigenital setae present in the female. ........................... dissociatus Abé, 1990

6b. Anal plate completely separated from the another plate by a wide strip of striated membranous cuticle in the female. Three pairs of perigenital setae present in the female.

6c. Anal plate partly separated from the another plate by lateral incisions of membranous cuticle in the female. More than three pairs of perigenital setae present in the female.

7a. The position of setae pes-iv-a approximately same as or more medial than that of setae aes-ii-v. Posterior dorsal plate laterally exserted at terminal end. Accessory process

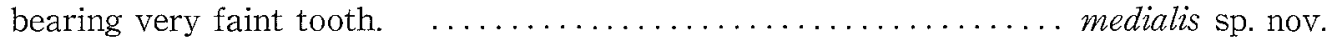

7b. The position of setae pes-iv-a clearly lateral than that of setae aes-ii-v. Posterior dorsal plate not exserted at terminal end. Lateral claw completely smooth.

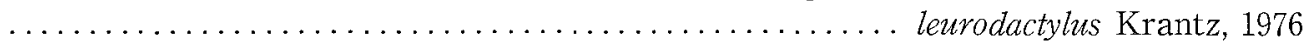

8a. Four pairs of short perigenital setae present in the female. Paneling on dorsal plates clear. Accessory process palmate type with several teeth. ..... ezoensis Abé, 1990

$8 \mathrm{~b}$. Five pairs of long perigenital setae present in the female. Paneling on dorsal plates inconspicuous. Accessory process palmate type with several teeth.

atuy Abé, 1990

8c. More than 10 perigenital setae present on each side of genital foramen in the female. Accessory process bearing long delicate teeth. $\ldots \ldots \ldots \ldots \ldots$ compressus sp. nov.

\section{Rhombognathus atuy Abé 1990}

[Japanese name: Umibe-kaisoudani]

(Figs. 24-27)

Rhombognathus atuy Abé 1990b, 517-523, figs. 1-4.

Specimens examined. One female (paratype), on Sargassum sp. at $0.5 \mathrm{~m}$ depth in tide pool, intertidal, Usujiri, Pacific coast of Hokkaido, 12.vi.1986, H. Abé coll. ; 1 male (paratype) and 1 tritonymph, on Corallina sp. at $0.1 \mathrm{~m}$ depth in tide pool, intertidal, Mitsuishi, Pacific coast of Hokkaido, 8.xii. 1988, H. Abé coll.

Female (paratype)

Dorsum (Fig. 24A) : AD weakly convex anteriorly and protruded posteriorly, ornamented with chevron-shaped areolation posteriorly. OC furnished with two large corneae. PD furnished with two pairs of setae (ds-iv and ds-v). 


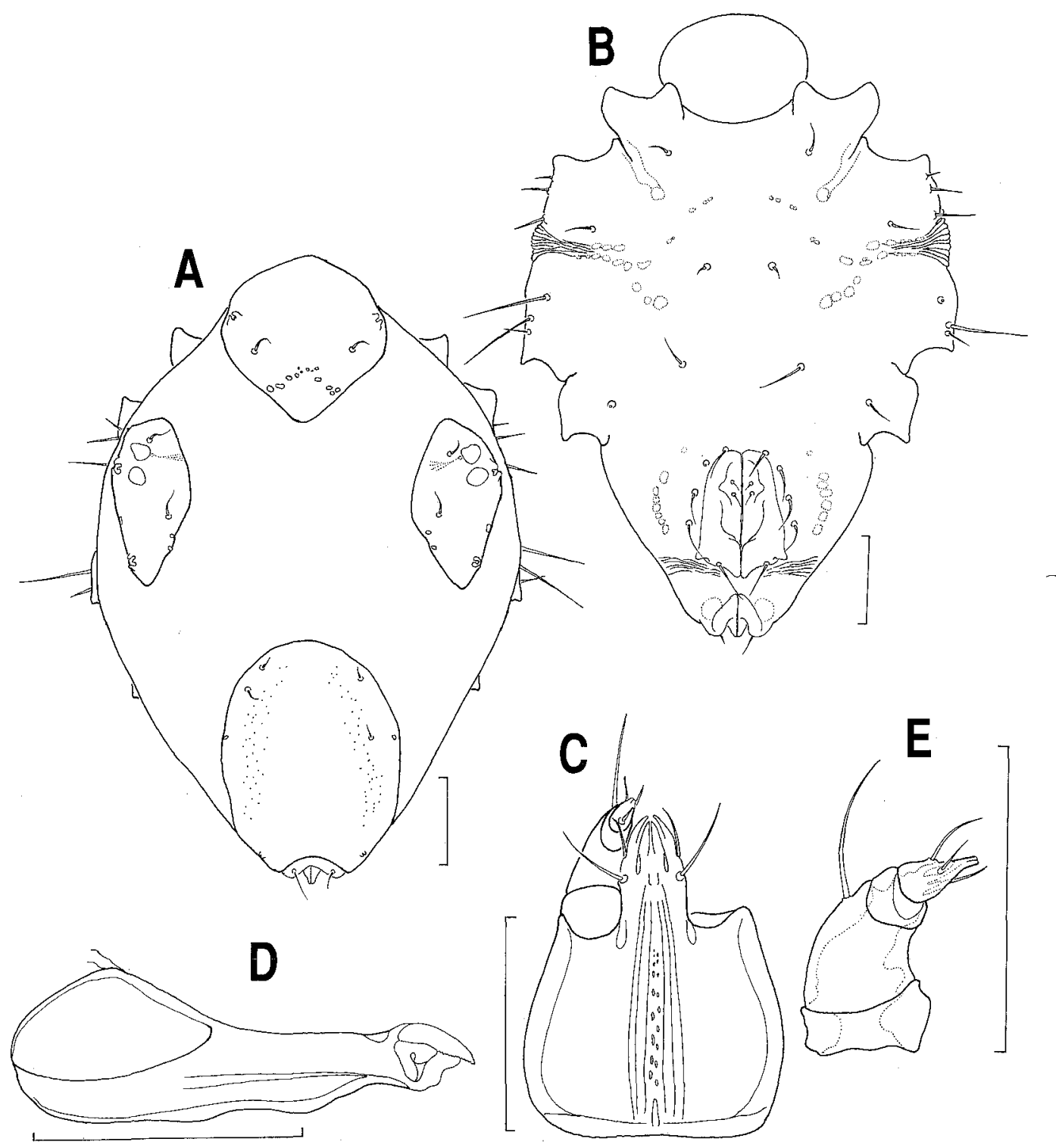

Fig. 24. Rhombognathus atuy Abé, 1990, female (paratype). A, idiosoma (Ds); B, idiosoma (Vr) ; C, gnathosoma (Vr) (left palp omitted); D, chelicera (R); E, palp (L). Scale bars $=50 \mu \mathrm{m}$.

Venter (Fig. 24B) : Epimeral and genital plates fused to form a single plate, and anal plate partly fused. Setae aes-ii-adj located on lateral margins, each consisting of three setae ; pes-iii-adj placed dorsolaterally, each consisting of one seta. Genitoanal region (Fig. 25A) slightly incised laterally with membranous cuticle. Genital acetabula three pairs. Spermatheca bilobed. Five pairs of long thick filiform perigenital setae located around genital foramen. Subgenital setae short filiform; two pairs on genital sclerites, arranged $2-0$. Adanal setae placed on anal papilla dorsoproximally.

Gnathosoma (Fig. 24C) : Rostrum nearly lanceolate, not reaching to level of distal end of 


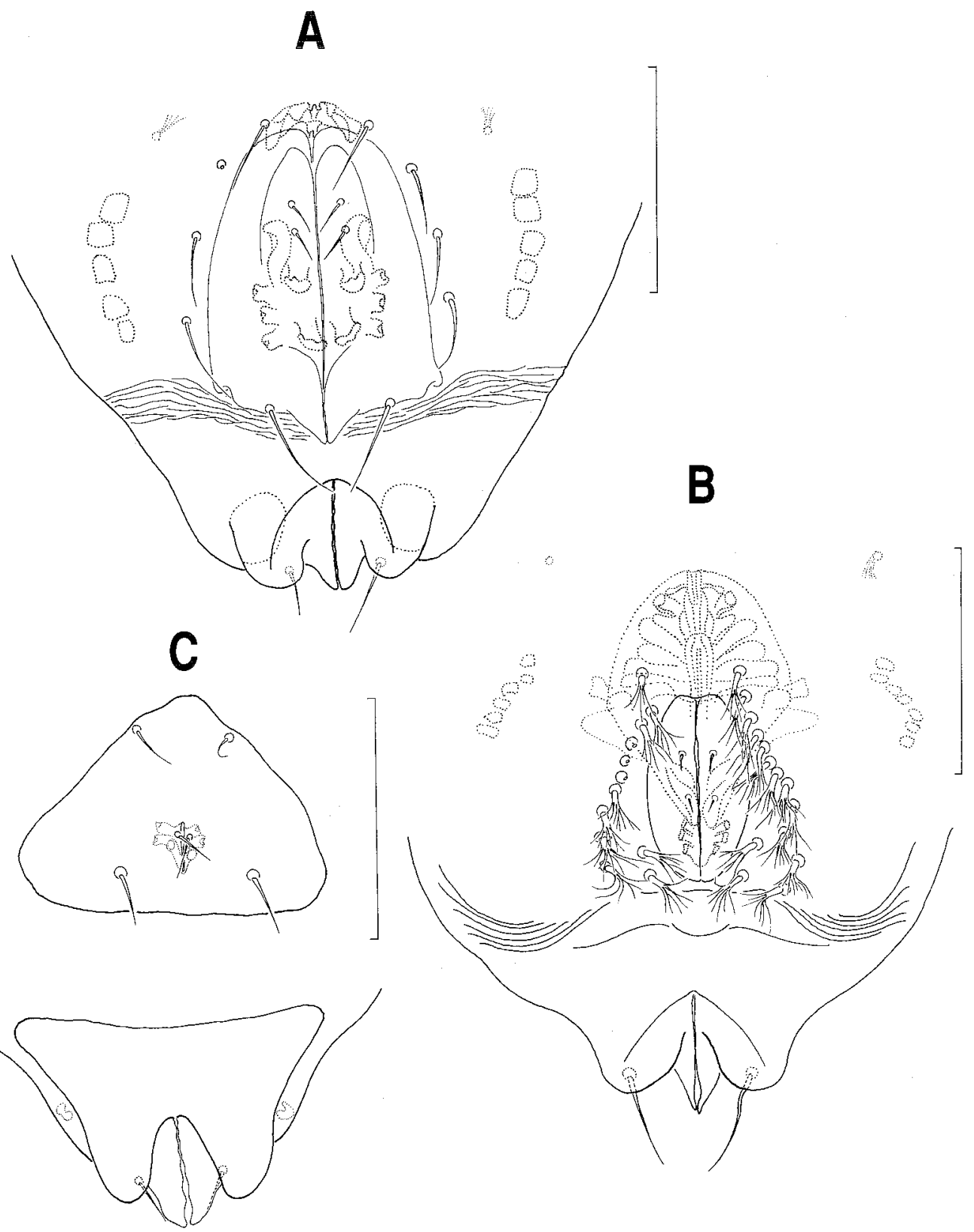

Fig. 25. Rhombognathus atuy Abé, 1990, genitoanal regions. A, female (paratype); B, male (paratype) ; C, tritonymph. Scale bars $=50 \mu \mathrm{m}$.

palp. Rostral setae two pairs. Chelicera (Fig. 24D) elongate, with movable digit bearing 11 -12 minute denticles along dorsal edge. Palp (Fig. 24E) typical form in the genus.

Legs (Figs. 26A-D) : Short seta usually rough; long seta smooth. Lateral claw with palmate accessory process. Solenidion (cf. Figs. 27A,B) long bacilliform on posterodorsal 


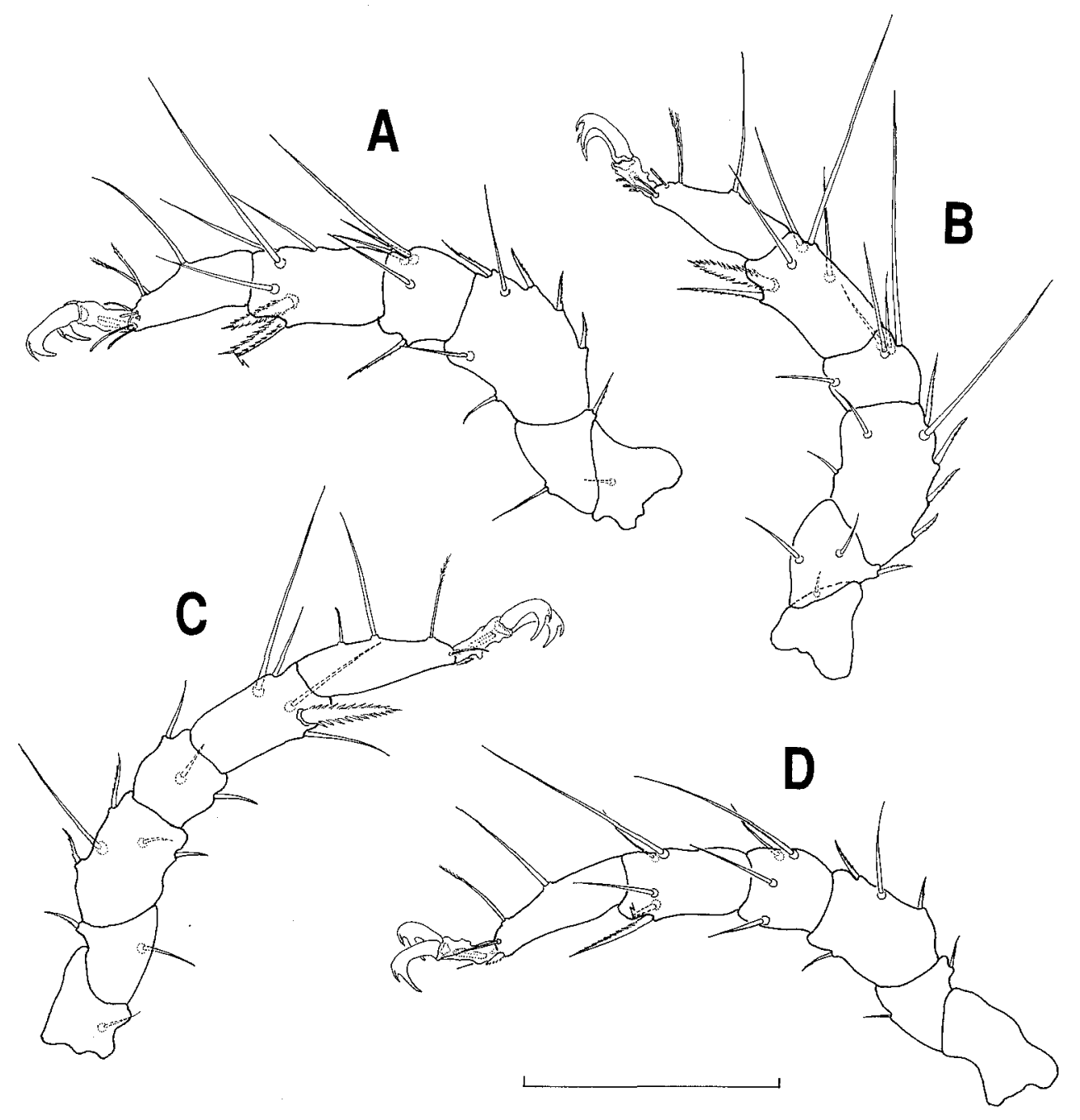

Fig. 26. Rhombognathus atuy Abé, 1990, female (paratype). A, leg I (L) ; B, leg II (L); C, leg III (R); D, leg IV (R). Scale bar $=100 \mu \mathrm{m}$.

surface of claw fossa. Famulus (cf. Fig. 27A) papilliform with fine canaliculus at just ventroproximally to solenidion. Tarsus III (Fig. 27C) with four dorsal setae. Tarsus IV (Fig. 27D) with three dorsal setae (one long filiform seta on basal claw fossa, one plumose seta on claw fossa, one fine filiform seta on anterodorsal surface) and two parambulacral setae (one single euphathidium on posterior surface, one scaliform proeuphathidium on anterior surface).

\section{Male (paratype)}

Genitoanal region (Fig. 25B) furnished with branched perigenital setae. Subgenital setae two pairs on genital sclerites, arranged $2-0$. Genital acetabula three pairs. Spermatophorotype massive and obovate.

Tarsus IV (Fig. 27E) furnished with three dorsal setae (one long thick filiform seta on 


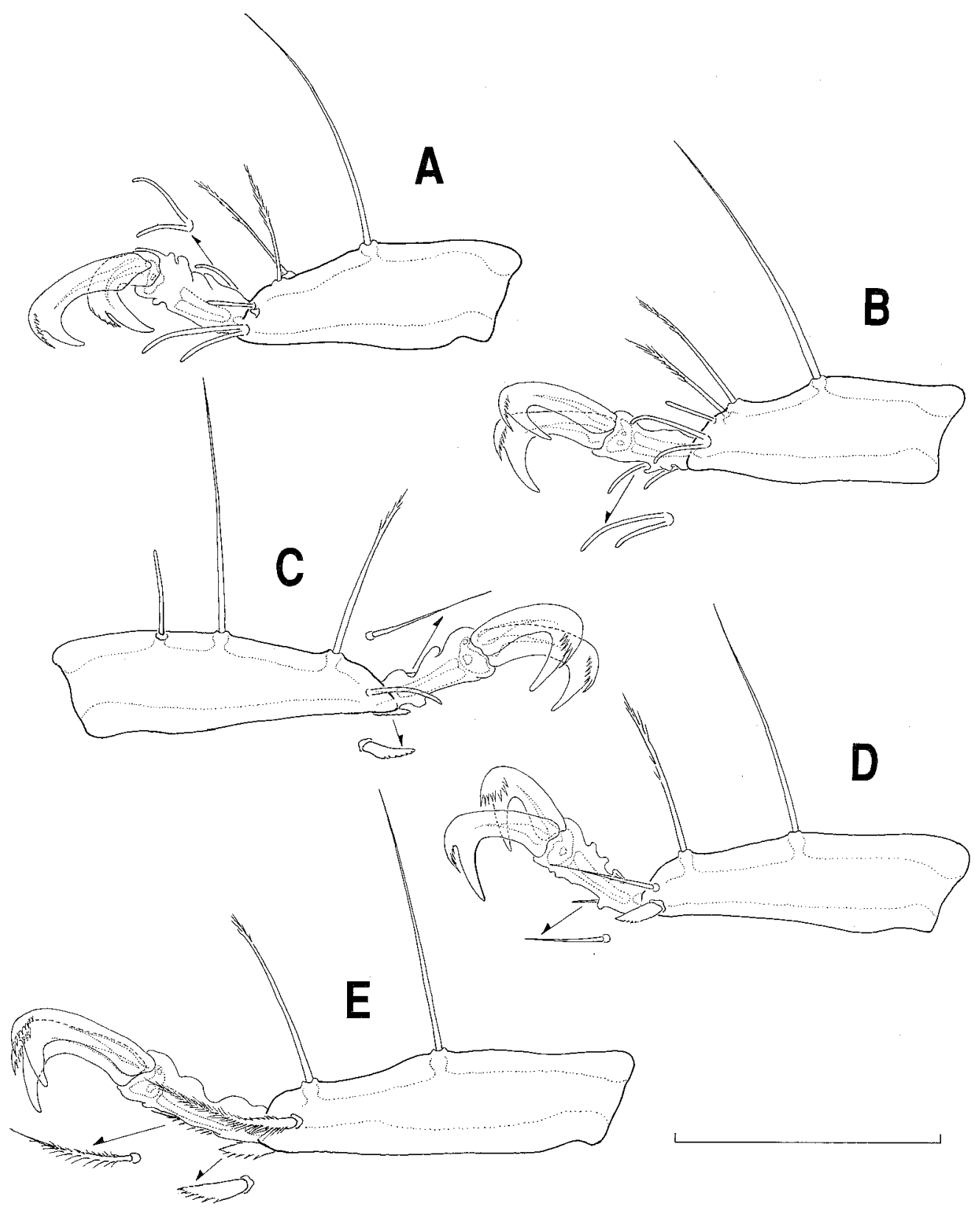

Fig. 27. Rhombognathus atuy Abé, 1990, female (paratype). A, tarsus I (L) ; B, tarsus II (L); C, tarsus III (R) ; D, tarsus IV (R). Male (paratype). E, tarsus IV (R). Scale bar $=50 \mu \mathrm{m}$.

basal claw fossa, one plumose seta on claw fossa, one delicate plumose seta on anterodorsal surface of claw fossa) and two parambulacral setae (one long plumose proeuphathidium on posterior surface, one scaliform proeuphathidium on anterior surface). 
Table 1. Summary of critical taxonomic characters for $R$. sinensoideus and $R$. atuy.

\begin{tabular}{lccc}
\hline \multicolumn{1}{c}{ Characters } & \multicolumn{2}{c}{ Character states } \\
\cline { 3 - 4 } \cline { 3 - 3 } No. of dorsal plates & $R$. atuy & $R$. sinensoideus \\
\cline { 2 - 3 } No. of dorsal setae on PD & 4 plates & 4 plates \\
No. of epimeral plates & 2 pairs & 2 pairs \\
No. of adj on AE & single plate & single plate \\
No. of adj on PE & $2-3$ pairs & $2-3$ pairs \\
No. of perigenital setae in the female & $1-2$ pairs & 1 pair \\
No. of perigenital setae in the male & 5 pairs & 5 pairs \\
Form of accessory process & $11-12$ pairs & $10-13$ pairs \\
No. of setae of basifemur II & $9-12$ teeth & ca. 15 teeth \\
Telofemora I-IV: & 3 setae & 3 setae \\
Genua I-IV : & $7-(6,7)-5-4$ & $6-6-(4,5)-(4,5)$ \\
Tibiae I-IV : & $5-(4,5)-3-4$ & $5-5-(3,4)-4$ \\
Large bipectinate setae of tibiae I-IV : & $6-6-(5,6)-5$ & $6-6-5-5$ \\
& $2-1-1-1$ & $2-1-1-1$ \\
\hline
\end{tabular}

Tritonymph

Idiosoma $348 \mu \mathrm{m}$ long, $208 \mu \mathrm{m}$ wide, gnathosoma-length/idiosoma-length 0.19 .

Dorsum : AD $60 \mu \mathrm{m}$ long, $62 \mu \mathrm{m}$ wide, concave posteriorly. PD $100 \mu \mathrm{m}$ long, $72 \mu \mathrm{m}$ wide, convex anteriorly. $\mathrm{AD}$ and $\mathrm{PD}$ separated by interval about two times as long as $\mathrm{PD}$. OC 70 $\mu \mathrm{m}$ long.

Venter: AE $78 \mu \mathrm{m}$ long, $168 \mu \mathrm{m}$ wide, furnished with a number of subsurface pores medially as well as along posterior margin, with two aes-ii-adj on each lateral margin. PE $96 \mu \mathrm{m}$ long, furnished with several subsurface pores along anteroventral margin. A small subsurface pore placed on membranous cuticle medially on each side.

Genitoanal region (Fig. 25C) : Genital plate $60 \mu \mathrm{m}$ long, $60 \mu \mathrm{m}$ wide, bluntly protruded anteriorly, nearly truncated posteriorly, furnished with two pairs of perigenital and one pair of subgenital setae, bearing a tiny subsurface pore on each lateral margin. Primordial genital slit with three pairs of internal genital acetabula. Anal plate small, nearly truncated anteriorly.

Legs: Leg chaetotaxy of trochanters I-IV, 1-1-1-0; basifemora I-IV, 2-3-2-2 ; telofemora I-IV, 6-6-4-4; genua I-IV, 5-5-3-4; tibiae I-IV, 6-6-5-5. Distinct bipectinate setae on tibiae I-IV : 2-1-1-1.

Morphological variation and abnormality

The number of setae aes-ii-adj and pes-iii-adj on each side of idiosoma varies from two to three, and zero to one respectively. The number of the perigenital setae on each side of the genital foramen varies from 11 to 12 in the male, five to six in the female. The leg chaetotaxy varies among adult specimens as follows: Trochanters I-IV, $(0,1)-(0,1)-1-0$; basifemora I-IV, 2-3-2-2 ; telofemora I-IV , 7- $(6,7)-5-4$; genua I-IV, 5-(4,5)-3-4 ; tibiae I-IV, 6-6- $(5,6)-5$.

\section{Remarks}

Rhombognathus atuy is distinguished from the congeners by the following character states : 1) dorsal plates separated, and with weak paneling, 2) posterior dorsal plate with one pair of setae, 3) perigenital setae five pairs in the female, 11-12 pairs in the male, 4) bipectinate setae of tibia I-IV : $2-1-1-1$, 5) lateral claw with palmate accessory process bearing 9-12 teeth.

In the original description (Abé, 1990b, p. 518), the author noted "(AD) without distinct 
dorsal pore." This description, however, is due to a misobservation, and a polygonal dorsal pore exists on each lateral margin of AD.

Bartsch (1992) described Rhombognathus sinensoideus from the coast of Hong Kong. Judging from the original description and from the examination of two males (No. As167, As168) in the private collection of I. Bartsch, the character states of critical taxonomic characters in $R$. sinensoideus is almost accord with those in $R$. atuy (Table 1). Only a discernible difference between these two species is the leg chaetotaxy of telofemora. $R$. sinensoideus has six ( 2 ventral/4 dorsal) setae on telofemur $\mathrm{I}$, while $R$. atuy has seven (2 ventral $/ 5$ dorsal) setae. Leg chaetotaxy, however, is apt to vary especially on short setae. Hence, although I here treat these two forms as two distinct species, there remains a possibility that these two species might be two geographical forms of one species. Further information especially on the geographic variation is indispensable to solve this question.

Habitat-Intertidal zone: Algae - Enteromorpha intestinalis on gravels, Sargassum thunbergii, S. fulvellum, S. sagamianum, Cystoseira hakodatensis, Neorhodomela aculeata, Corallina pilulifera, Sargassum sp., Corallina sp. in tide pool. Polychaeta - Pseudopotamilla occelata in tide pool. Mussels - Mytilus edulis, Septifer virgatus on ledge. Barnacles - Balanus cariosus on flat. Coarse sandy sediment. Boulders.

Distribution in Hokkaido-Teuri Island, Atsuta, Oshoro, Tomari, Kikonai, Usujiri, Usu, Muroran, Tomakomai, Mitsuishi, Erimo, Esashi.

\section{Rhombognathus compressus sp. nov.}

[Japanese name: Hirata-kaisoudani]

(Figs. 28-31)

Type series. Holotype: Female, on Enteromorpha intestinalis on gravels at a depth of $0.1 \mathrm{~m}$, intertidal, Lake Akkeshi (Kamu-iwa), Pacific coast of Hokkaido, 2.vi.1988, H. Abé coll. Allotype: Male, data same as the holotype. Paratypes: 5 females, 5 males, and 1 tritonymph, data same as the holotype ; 1 deutonymph, on Pelvetia wrightii on tetrapod at a depth of $0.1 \mathrm{~m}$, intertidal, Odaitô, Okhotsk coast of Hokkaido, 21.xii.1989, H. Abé coll.

Female (holotype)

Idiosoma $384 \mu \mathrm{m}$ long, $260 \mu \mathrm{m}$ wide. Color in life dark green.

Dorsum (Fig. 28A) : Dorsal plate ornamented with clear panels, and partly with fine canaliculi. AD and PD separated by interval less than AD-length. AD $92 \mu \mathrm{m}$ long, $112 \mu \mathrm{m}$ wide, truncated posteriorly, ornamented with fine areolation posteriorly, with a dorsal pore near each lateral margin. OC $102 \mu \mathrm{m}$ long, extending anteriorly to level of posterior margin of $\mathrm{AD}$, reaching posteriorly at level slightly anterior to insertion of leg III, furnished with two large corneae and two large polygonal pores, bearing one tiny pore-like structure anteriorly to posterior pore, one maze-like subsurface pore medially to anterior cornea, and two tiny subsurface pores near posteromedial margin. Areolation indistinct. PD $208 \mu \mathrm{m}$ long, $132 \mu \mathrm{m}$ wide, reaching anteriorly to level of insertion of leg III, furnished with a small subsurface pore on lateral margin, and with dorsal pore on posterolateral margin on each side. Costae inconspicuous.

Chaetotaxy of dorsal region: All dorsal setae short. Setae ds-i on AD; ds-ii each on OC near anterior margin; ds-iii each on OC near medial margin; ds-iv and ds-v on PD, near anterolateral margin.

Venter (Fig. 28B) : Epimeral and genital plates fused to form a single plate, and anal plate partly fused. Ventral plates are entirely reticulated with faint panels. Epimeral region furnished with several subsurface pores medially, and with epimeral pore between insertions of leg I and leg II on each side, weakly incised laterally with membranous cuticle bordering 


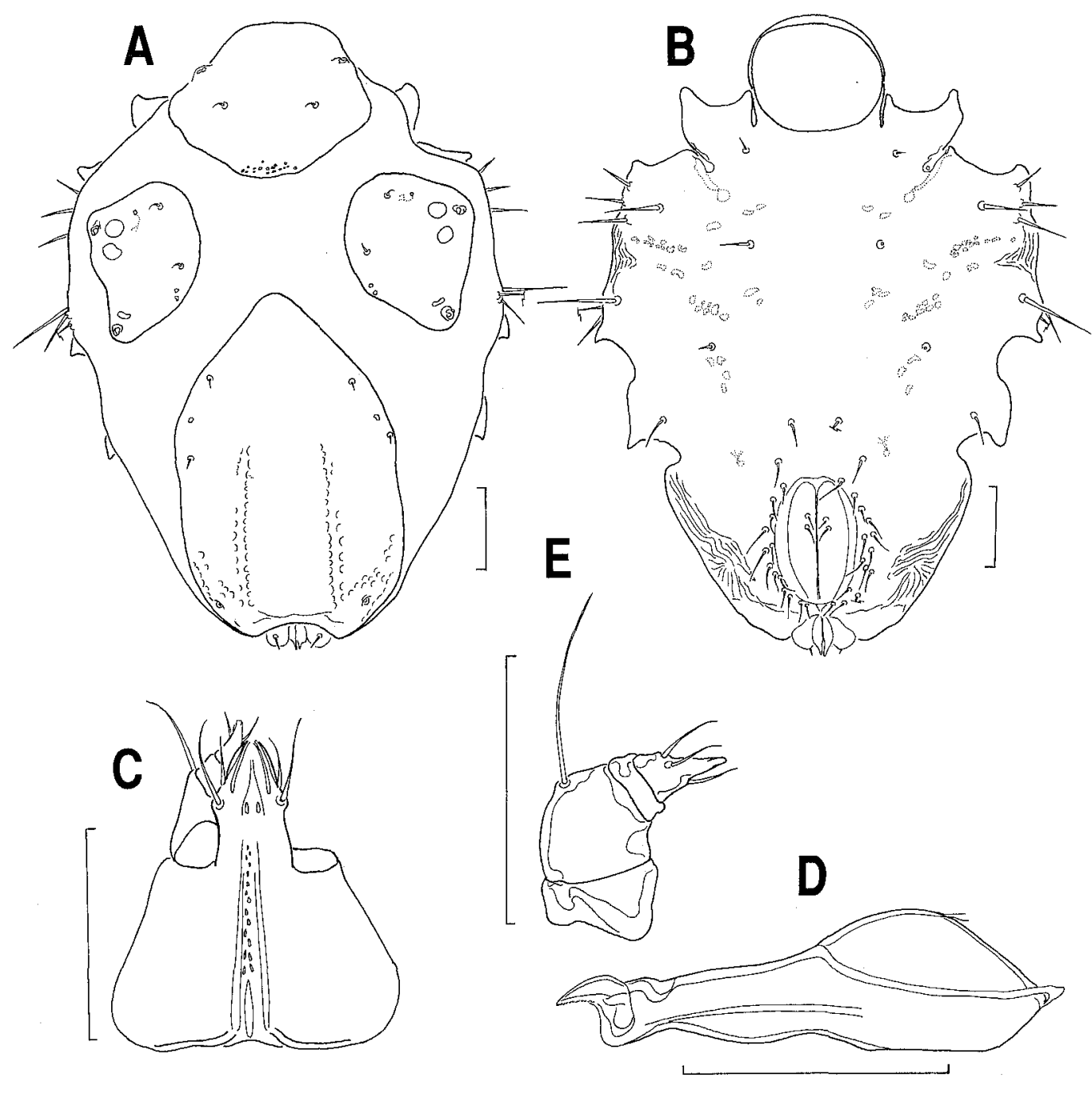

Fig. 28. Rhombognathus compressus sp. nov., female (holotype). A, idiosoma (Ds) ; B, idiosoma (Vr) ; C, gnathosoma (Vr) (left palp omitted); D, chelicera (L); E, palp (L). Scale bars $=50 \mu \mathrm{m}$.

several subsurface pores between insertions of leg II and leg III.

Chaetotaxy of epimeral region: Setae aes-i located at posteriorly to camerostome; aes-ii-lat placed medially at level posterior to insertion of leg II; aes-ii-v placed most medially at level slightly anterior to lateral incision; aes-ii-adj located on lateral margins, each consisting of three setae; pes-iii-lat placed dorsally on posterior epimeral region; pes-iii-v near lateral margins; pes-iv-a placed medially, at level of insertion of leg III ; pes-iv-p located at level anterior to insertion of leg IV ; pes-iii-adj placed dorsolaterally, each consisting of one seta.

Genitoanal region (Fig. 29A): Genitoanal region incised laterally with membranous cuticle, furnished with two round subsurface pores on anterior portion of genital region. Genital foramen $76 \mu \mathrm{m}$ long, $48 \mu \mathrm{m}$ wide, occupying from level slightly posterior to insertion of leg IV to level anterior to anal foramen. Genital sclerites band-like, with three pairs of 

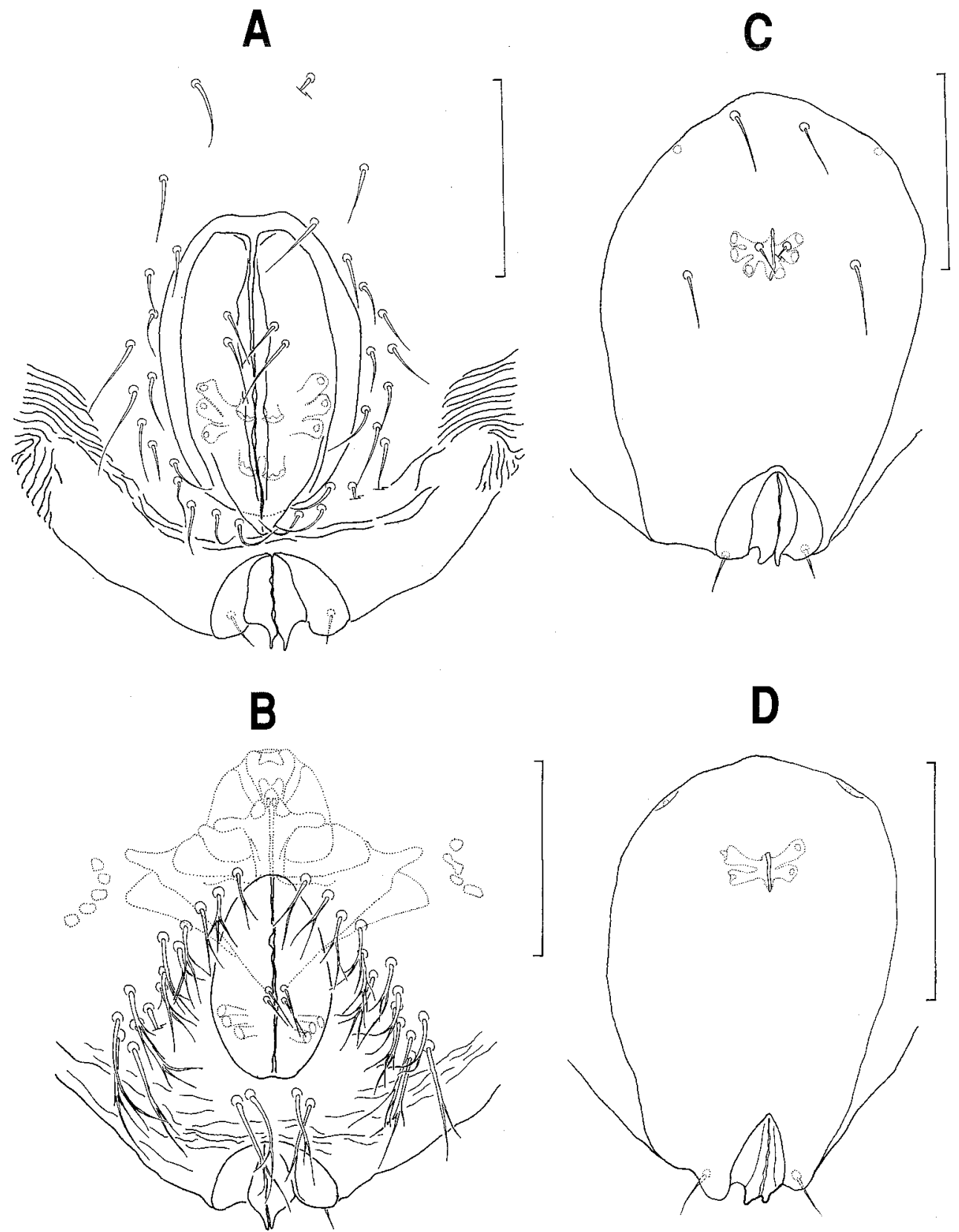

Fig. 29. Rhombognathus compressus sp. nov., genitoanal regions. A, female (holotype); B, male (paratype); C, tritonymph (paratype); D, deutonymph (paratype). Scale bars $=50 \mu \mathrm{m}$.

internal genital acetabula. Spermatheca indistinct.

Chaetotaxy of genitoanal region : 16 and 15 filiform perigenital setae located at each side of genital foramen as arranged in Fig. 29A. Subgenital setae filiform; two pairs on genital sclerites, arranged 2-0. Adanal setae placed on anal papilla dorsoproximally. 

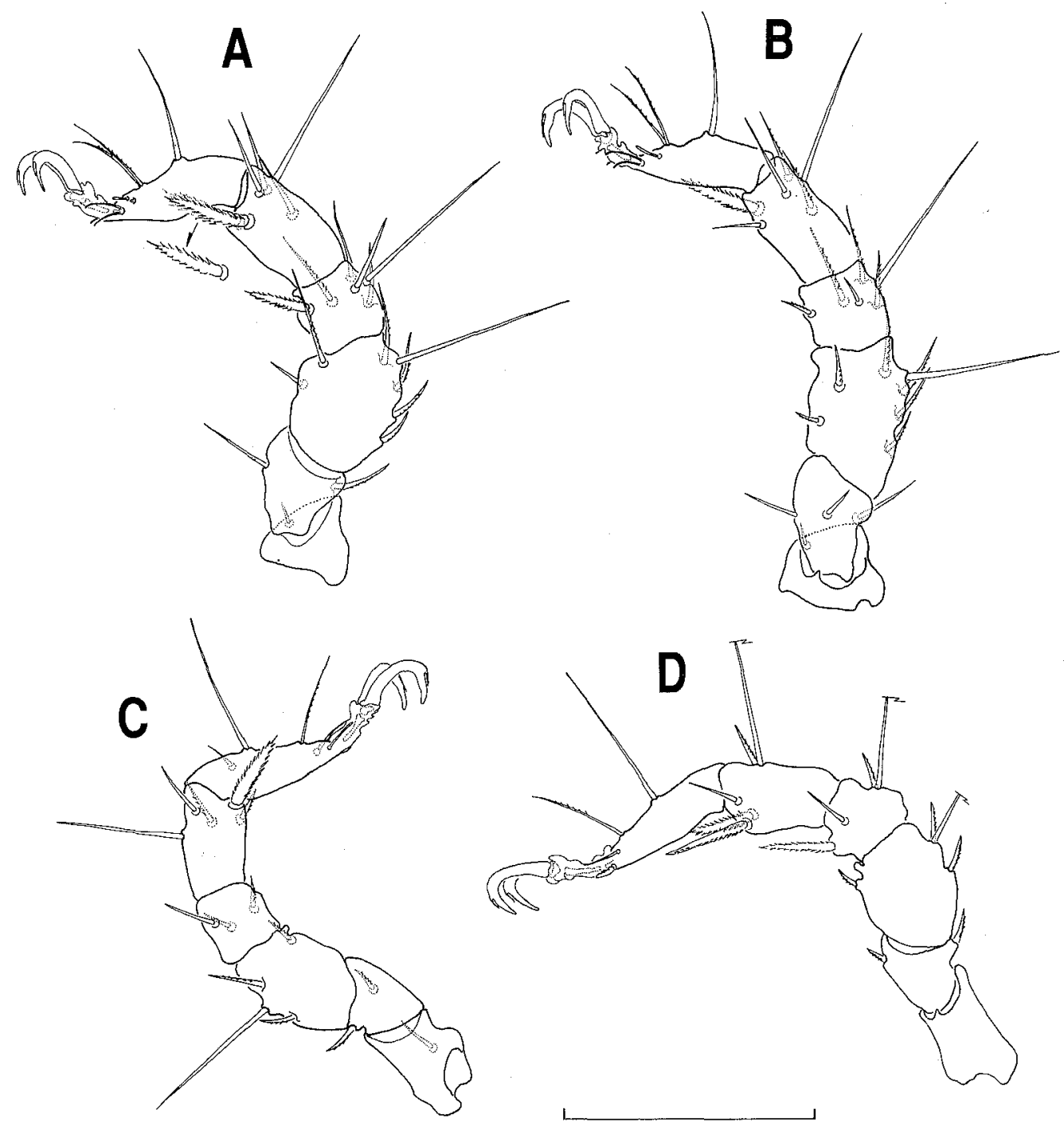

Fig. 30. Rhombognathus compressus sp. nov., female (paratype). A, leg I (L); B, leg II (L); C, leg III (R); D, leg IV (R). Scale bar $=100 \mu \mathrm{m}$.

Gnathosoma (Fig. 28C) : $74 \mu \mathrm{m}$ long, $70 \mu \mathrm{m}$ wide, gnathosoma-length/idiosoma-length 0 . 19. Base, length/width 0.64 . Rostrum $36 \mu \mathrm{m}$ long, nearly lanceolate, not reaching to level of distal end of palp. Rostral setae two pairs as follows: Proximal pair long and robust, at swollen point; distal pair short, at just anterior to proximal pair. Chelicera (Fig. 28D) with basal segment $80 \mu \mathrm{m}$ long, and movable digit $14 \mu \mathrm{m}$ long, bearing 10-12 minute denticles along dorsal edge. Fixed digit weakly developed. Palp (Fig. 28E) $44 \mu \mathrm{m}$ long; P-1 short and cylindrical ; $\mathrm{P}-2$ longest and robust, with a long filiform seta distidorsally; $\mathrm{P}-3$ short and cylindrical; P-4 conical, with three short and thick filiform setae intermediately, and with two appressed blunt spiniform projections terminally.

Legs (Figs. 30A-D) : Length of legs I, II, III, IV =218, 222, 210, $222 \mu \mathrm{m}$ respectively. 


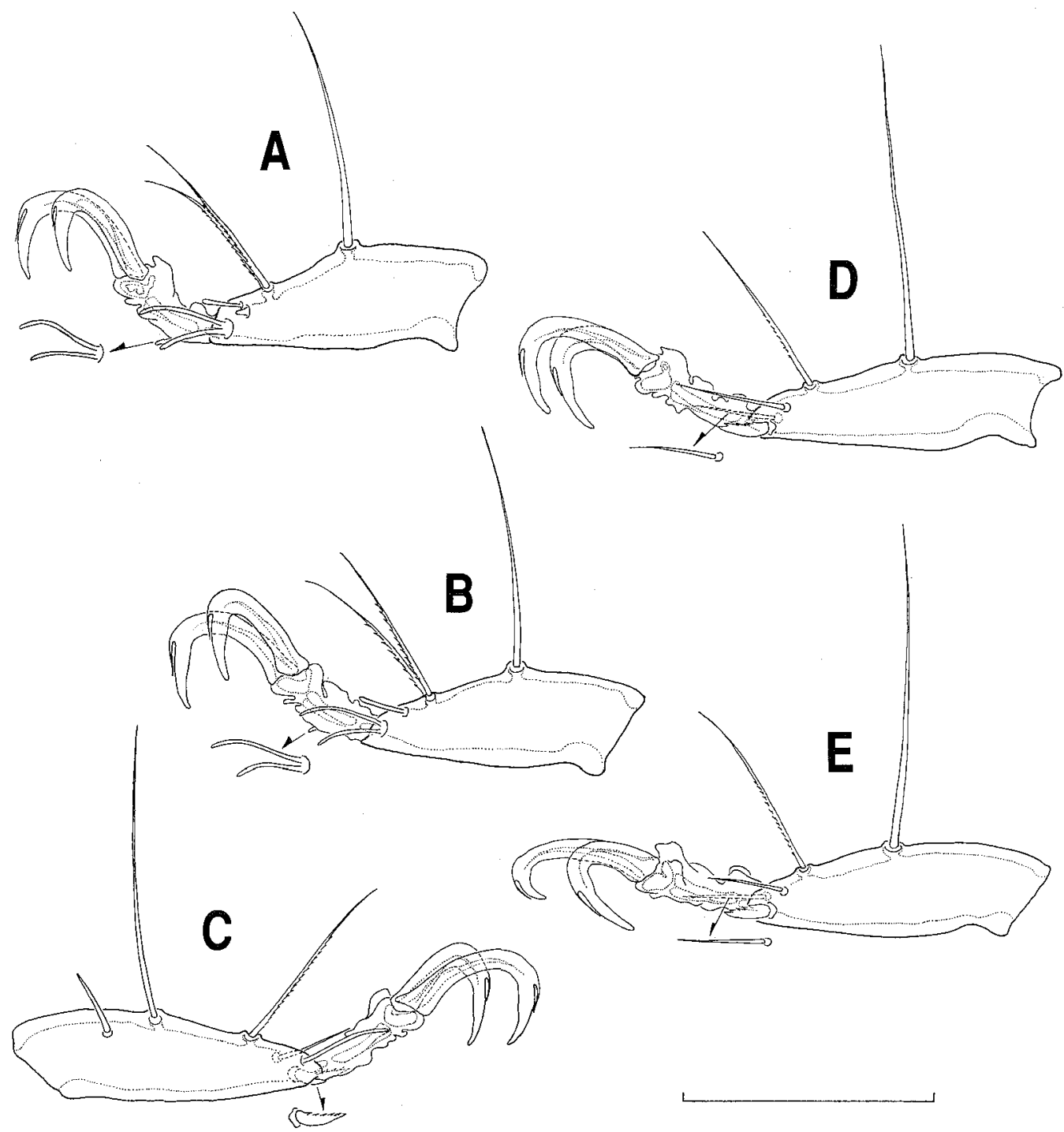

Fig. 31. Rhombognathus compressus sp. nov., female (holotype). A, tarsus I (L); B, tarsus II (L); C, tarsus III (R); D, tarsus IV (R). Male (allotype). E, tarsus IV (R). Scale bar $=50 \mu \mathrm{m}$.

Ornamentation indistinct. Lateral claw with a long delicate tooth.

Leg chaetotaxy as follows: Trochanters I-IV, 1-1-1-0; basifemora I-IV, 2-3-2-2; telofemora I-IV, 7-7-4-4; genua I-IV, 6-6-3-4; tibiae I-IV, 6-6-5-5. As for large bipectinate setae: Genua I-IV, 1-0-0-1; tibiae I-IV, 2-1-1-2. 'Tarsus I (Fig. 31A) with three dorsal setae, one solenidion, one famulus, and four parambulacral setae (paired doublet euphathidia). Solenidion long bacilliform on posterodorsal surface of claw fossa. Famulus papilliform with fine canaliculus at just ventrally to solenidion. Tarsus II (Fig. 31B) with three dorsal setae, one solenidion, and four parambulacral setae. Solenidion long bacilliform on posterodorsal surface of claw fossa. Tarsus III (Fig. 31C) with four dorsal setae and two 
parambulacral setae (one single euphathidium on posterior surface, one scaliform proeuphathidium on anterior surface). Tarsus IV (Fig. 31D) with three dorsal setae (one long filiform seta on basal claw fossa, one faintly plumose seta on distal claw fossa, one fine filiform seta on anterodorsal surface) and two parambulacral setae (one filiform euphathidium on posterior surface, one scaliform proeuphathidium on anterior surface).

Male (allotype)

Idiosoma $356 \mu \mathrm{m}$ long, $256 \mu \mathrm{m}$ wide, gnathosoma-length/idiosoma-length 0.21 , resembling the female in essential respects except for character states of genitoanal region.

Genitoanal region (Fig. 29B) furnished with a round subsurface pore, and a series of polygonal subsurface pores on each side of genital foramen, bearing branched 16 perigenital setae on each side of the foramen as arranged in Fig. 29B. Genital foramen $52 \mu \mathrm{m}$ long, 28 $\mu \mathrm{m}$ wide. Subgenital setae two pairs on genital sclerites, arranged $2-0$. Genital acetabula three pairs. Spermatophorotype (cf. Fig. 29B) $72 \mu \mathrm{m}$ long, $70 \mu \mathrm{m}$ wide, massive and rhombic.

Tarsus IV (Fig. 31E) similar to that in the female.

\section{Tritonymph (paratype)}

Idiosoma $324 \mu \mathrm{m}$ long, $224 \mu \mathrm{m}$ wide, gnathosoma-length/idiosoma-length 0.20 .

Dorsum : AD $78 \mu \mathrm{m}$ long, $92 \mu \mathrm{m}$ wide. PD $140 \mu \mathrm{m}$ long, $102 \mu \mathrm{m}$ wide, protruded anteriorly, furnished with two dorsal setae. AD and PD separated by interval about PD-length. OC $76 \mu \mathrm{m}$ long.

Venter: AE $68 \mu \mathrm{m}$ long, $184 \mu \mathrm{m}$ wide, furnished with two aes-ii-adj on each lateral margin. A pair of small subsurface pores placed on membranous cuticle posteriorly to $\mathrm{AE}$. PE $98 \mu \mathrm{m}$ long, furnished with several subsurface pores along anteroventral margin. Pes-iiiadj absent.

Genitoanal region (Fig. 29C) : Genital plate $108 \mu \mathrm{m}$ long, $84 \mu \mathrm{m}$ wide, rounded anteriorly, furnished with two pairs of perigenital and one pair of subgenital setae, bearing a tiny subsurface pore on each anterolateral margin. Primordial genital slit with three pairs of internal genital acetabula. Anal plate small, nearly truncated anteriorly.

Legs : Length of legs I, II, III, IV $=176,172,172,174 \mu \mathrm{m}$ respectively. Leg chaetotaxy of trochanters I-IV , 1-1-1-0 ; basifemora I-IV , 2-3-2-2 ; telofemora I-IV, 6-6-4-4 ; genua I-IV, 6-6-3-4; tibiae I-IV, 6-6-5-5. Distinct bipectinate setae on genua I-IV, 1-0-0-1; tibiae I-IV, 2-1-1-2.

\section{Deutonymph (paratype)}

Idiosoma $240 \mu \mathrm{m}$ long, $160 \mu \mathrm{m}$ wide, gnathosoma-length/idiosoma-length 0.23 .

Dorsum: Dorsal plates relatively well developed like adults. AD $66 \mu \mathrm{m}$ long, $72 \mu \mathrm{m}$ wide, nearly truncated posteriorly. OC $64 \mu \mathrm{m}$ long. PD $124 \mu \mathrm{m}$ long, $84 \mu \mathrm{m}$ wide, furnished with two dorsal setae.

Venter: AE $60 \mu \mathrm{m}$ long, $140 \mu \mathrm{m}$ wide, furnished with one aes-ii-adj. PE $80 \mu \mathrm{m}$ long, without pes-iii-adj.

Genitoanal region (Fig. 29D): Genital plate $90 \mu \mathrm{m}$ long, $62 \mu \mathrm{m}$ wide, furnished with primordial genital slit, two pairs of internal genital acetabula, and two round tiny subsurface pores. Genital seta absent.

Legs : Length of legs I, II, III, IV $=150,148,140,138 \mu \mathrm{m}$ respectively. Leg chaetotaxy of trochanters I-IV , 1-1-1-0; basifemora I-IV, 2-3-2-1; telofemora I-IV, 4-4-3-2 ; genua I-IV, 5-5-3-4 ; tibiae I-IV, 5-5-5-5. Distinct bipectinate setae on genua I-IV, $1-0-0-0$; tibiae I-IV, $2-1-1-1$.

Morphological variation and abnormality

The size range of the idiosoma, gnathosoma, and legs I-IV as follows.

Female ( $\mathrm{n}=6$ ). Idiosoma-length : 384-412 $\mu \mathrm{m}$, -width : 288-308 $\mu \mathrm{m}$; gnathosoma-length : 
74-84 $\mu \mathrm{m}$, -width : 70-74 $\mu \mathrm{m}$; leg-length : Leg I, 218-250 $\mu \mathrm{m}$; leg II, 208-244 $\mu \mathrm{m}$; leg III, 210 $-242 \mu \mathrm{m}$; leg IV, $222-246 \mu \mathrm{m}$.

Male $(\mathrm{n}=6)$. Idiosoma-length : $332-372 \mu \mathrm{m}$, -width : $244-272 \mu \mathrm{m}$; gnathosoma-length : 68-76 $\mu \mathrm{m}$, -width : 64-70 $\mu \mathrm{m}$; leg-length : Leg I, 200 $238 \mu \mathrm{m}$; leg II, 208-238 $\mu \mathrm{m}$; leg III, 204 $-224 \mu \mathrm{m}$; leg IV, 206-230 $\mu \mathrm{m}$.

One specimen has two pes-iii-adj on right side of idiosoma. Spermatheca is indistinct in some specimens. The length of perigenital setae in the female varies among specimens. The number of the perigenital setae on each side of the genital foramen varies from 14 to 17 in the female, 13 to 18 in the male. Basilar perigenital setae in the male varies from two to four.

The leg chaetotaxy varies among adult specimens as follows: Trochanters I-IV, 1-1-1 -0 ; basifemora I-IV, 2-3-(1,2)-2 ; telofemora I-IV, 7-7-(4,5)-4 ; genua I-IV, $(5,6)-(5,6)-3-4$; tibiae I-IV, 6-6-(4,5)-(4,5). One deutonymph specimen has one additional dorsal seta on tarsus II.

\section{Remarks}

Rhombognathus compressus is a member of the species characterized by having three setae on the basifemur of the second leg, viz. $R$. ambiguus Newell, $1984 ; R$. atuy Abe 1990 ; $R$. darwini Newell, $1984 ; R$. dissociatus Abé $1990 ; R$. ezoensis Abé $1990 ; R$. heterosetosus Bartsch, 1977 ; R. hirtellus Bartsch, 1992 ; R. leurodactylus Krantz, 1976 ; R. lionyx Trouessart, 1899 ; R. multisetosus Newell, 1984 ; R. reticulatus Krantz, 1976; R. sandwich Newell, $1984 ; R$. subtilis Bartsch, 1975. Moreover, the present species is recognizable on the basis of the presence of 14-17 perigenital setae on each side of the genital foramen in the female.

$R$. compressus most resembles $R$. darwini in having three setae on the basifemur of the second leg, and relatively many (9-19) perigenital setae on the each side of the genital foramen in the female. However, $R$. compressus is easily distinguished from $R$. darwini by the square-shaped ocular plate, the lateral claw with a long delicate tooth, and the leg chaetotaxy: Telofemora I-IV, 6-6-4-4; genua I-IV, 6-6-3-4; tibiae I-IV, 6-6-5-5; bipectinate setae on genua $I-I V, 1-0-0-1$; tibiae I-IV, 2-1-1-2.

The specific epithet is derived from the somewhat compressed body.

Habitat-Intertidal and subtidal zones: Algae - Enteromorpha intestinalis on gravels, Tichocarpus crinitus, Sargassum thunbergii, Fucus evanescens, Phyllospadix iwatensis in tide pool, Pelvetia wrightii on tetrapod, Agarum cribrosum at subtidal zone. Mussels - Mytilus edulis on tetrapod and ledge. Barnacles - Balanus cariosus on tetrapod. Boulders. Coarse sandy sediment.

Distribution in Hokkaido-Bakkai, Teuri Island, Oshoro, Date, Muroran, Tomakomai, Shizunai, Nakanose, Aininkappu, Lake Akkeshi, Odaitô, Oshinkoshin.

\section{Rhombognathus dissociatus Abé, 1990}

[Japanese name: Wakare-kaisoudani]

(Figs. 32-35)

Rhombognathus dissociatus Abé, 1990b, 523-529, figs. 5-8.

Specimens examined. One female (paratype), among Sargassum belt in crevice at low tide, intertidal, Oshoro (Kabuto Rock), Japan Sea coast of Hokkaido, 15. iv. 1986, H. Abé coll.; 1 male (paratype), on Polysiphonia at $0.3 \mathrm{~m}$ depth in tide pool, intertidal, Oshoro (Poromai), Japan Sea coast of Hokkaido, 6.iii.1989, H. Abé coll. ; 1 tritonymph, Mytilus edulis in tide pool, intertidal, Muroran (Charatsunai), Pacific coast of Hokkaido, 15.xi.1989, H. Abé coll.; 1 protonymph, coarse sandy sediment at low water line, intertidal, Oshoro (Shirikoshi), Japan Sea coast of Hokkaido, 1.v.1989, H. Abé coll. 


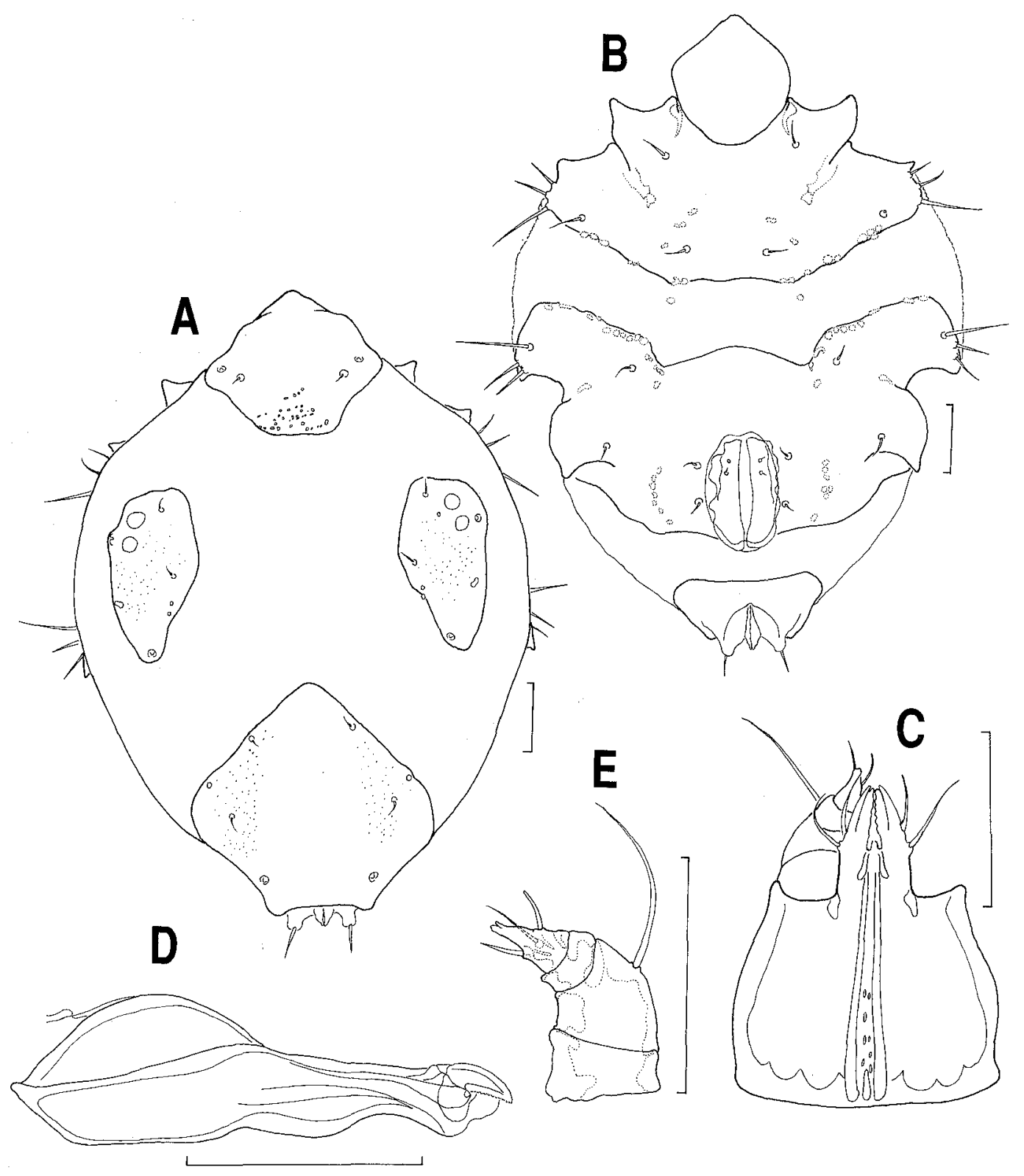

Fig. 32. Rhombognathus dissociatus Abé, 1990, female (paratype). A, idiosoma (Ds) ; B, idiosoma $(\mathrm{Vr})$; C, gnathosoma (Vr) (left palp omitted); D, chelicera (R); E, palp (R). Scale bars $=50 \mu \mathrm{m}$.

Female (paratype)

Dorsum (Fig. 32A) : Dorsal plate ornamented with clear panels. AD strongly protruded anteriorly and truncated posteriorly, ornamented with triangular areolation. OC furnished with two large corneae and two large polygonal pores. PD furnished with two pairs of dorsal setae (ds-iv and ds-v).

Venter (Fig. 32B) : Ventral plates three in number, completely separated. PE and genital 

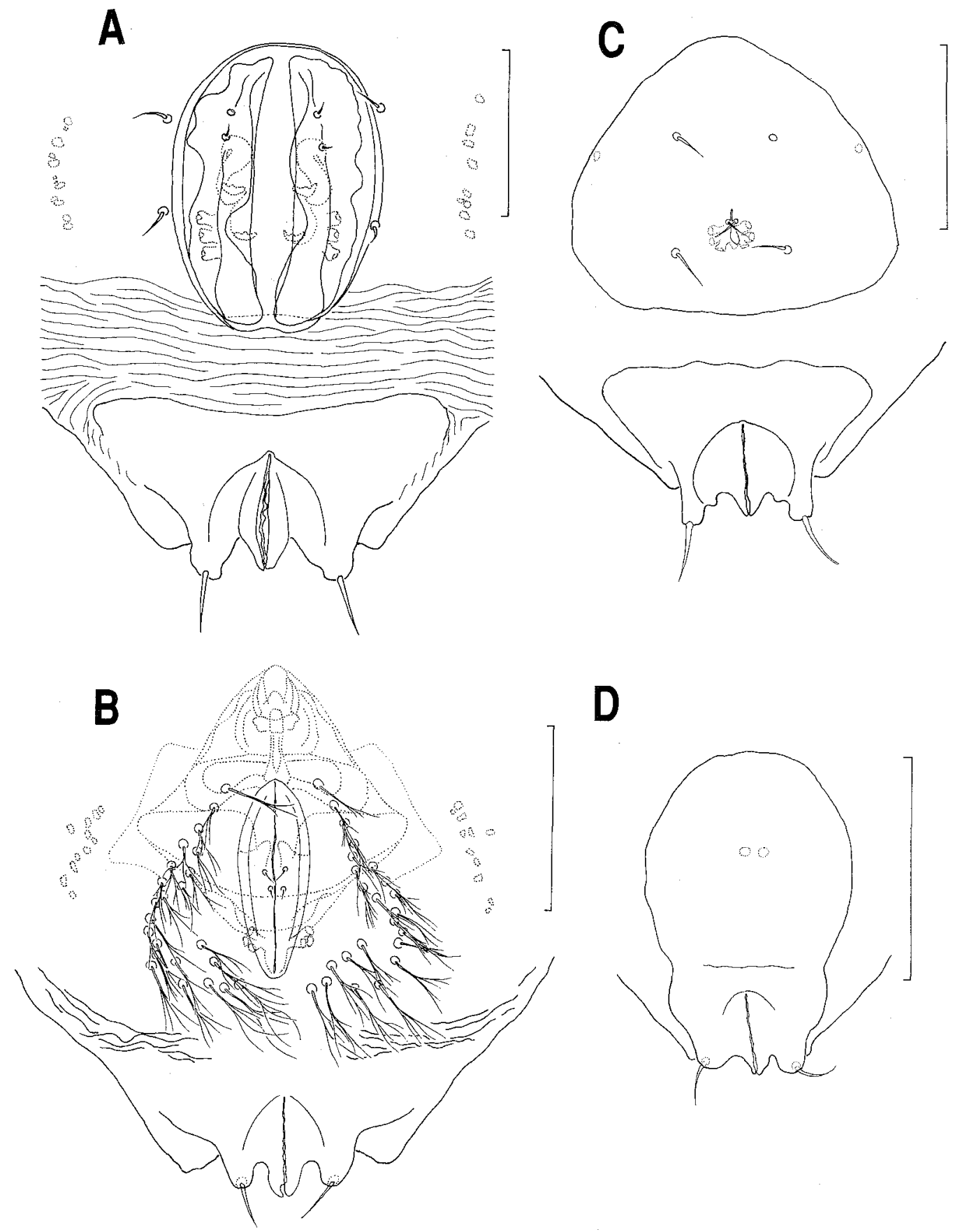

D

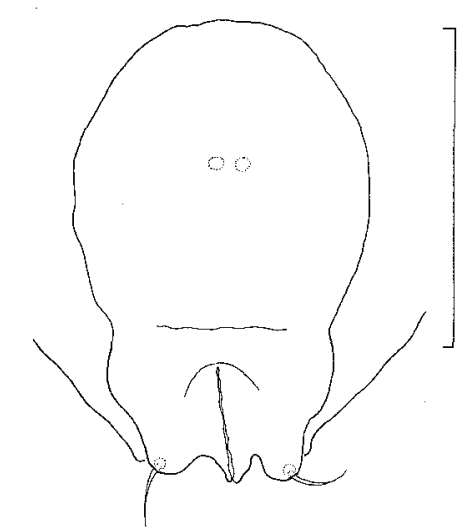

Fig. 33. Rhombognathus dissociatus Abé, 1990, genitoanal regions. A, female (paratype); B, male (paratype); C, tritonymph; D, protonymph. Scale bars $=50 \mu \mathrm{m}$. 

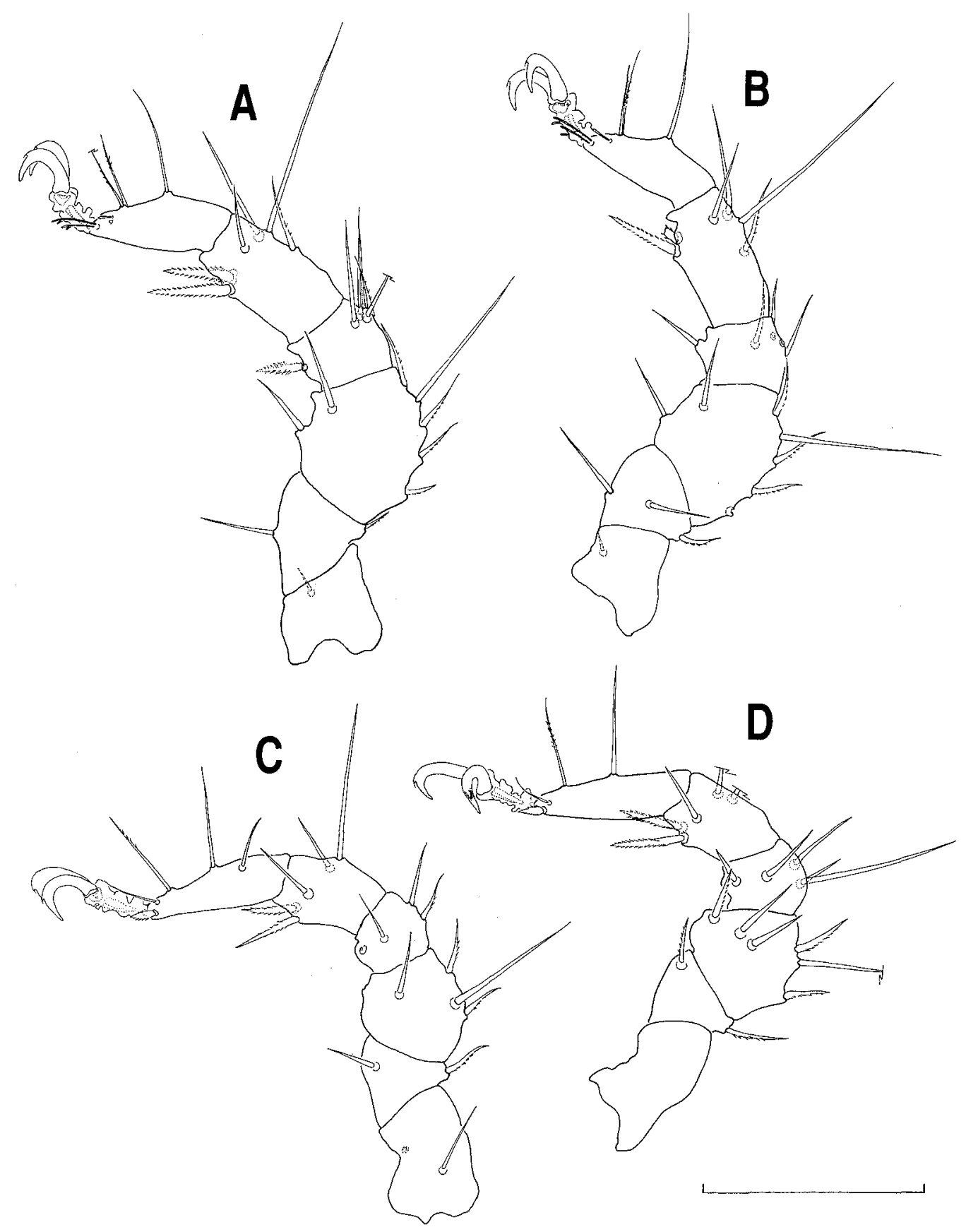

Fig. 34. Rhombognathus dissociatus Abé, 1990, female (paratype). A, leg I (L) ; B, leg II (L) ; C, leg III (R) ; D, leg IV (R). Scale bar $=100 \mu \mathrm{m}$. 


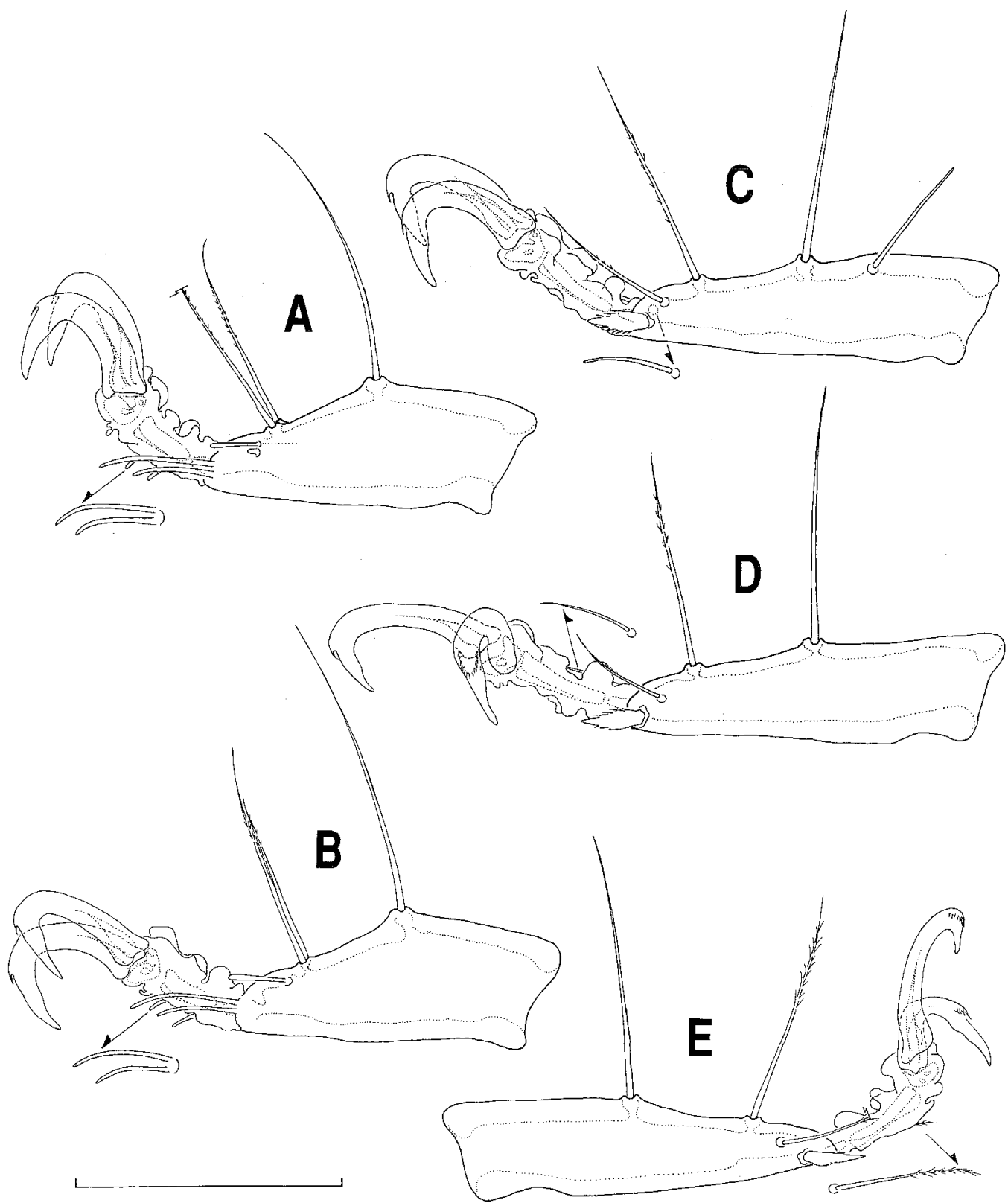

Fig. 35. Rhombognathus dissociatus Abé, 1990, female (paratype). A, tarsus I (L); B, tarsus II (L); C, tarsus III (R); D, tarsus IV (R). Male (paratype). E, tarsus IV (R). Scale bar $=50 \mu \mathrm{m}$.

plate fused to form a single middle plate. AE and middle plate separated from each other by a strip of membranous cuticle. Middle plate concave anteriorly, convex posteriorly. Anal plate surrounding anal papilla, completely separated from genital region by a strip of striated membranous cuticle. Setae aes-ii-adj located near lateral margins, each consisting of three setae ; pes-iii-adj placed on lateral margins of middle plate, each consisting of one thick seta. 
Genitoanal region (Fig. 33A): Genital region occupying medial portion of middle plate. Genital sclerites band-like, extending posteriorly somewhat beyond posterior margin of middle plate. Genital acetabula three pairs. Spermatheca bilobed. Two pairs of filiform perigenital setae located near genital foramen. Subgenital setae two pairs, arranged 2-0. Adanal setae robust, placed distidorsally on anal papillae.

Gnathosoma (Fig. 32C) : Rostral setae two pairs. Chelicera (Fig. 32D) with movable digit bearing 12-13 minute denticles along dorsal edge. Palp (Fig. 32E) typical form in the genus.

Legs (Figs. 34A-D) ornamented with fine porous panels which are clear only on telofemora. Lateral claw with tiny palmate accessory process. Solenidion (cf. Figs. 35A,B) long straight bacilliform on posterodorsal surface of claw fossa. Famulus (cf. Fig. 35A) papillifor$\mathrm{m}$ with fine canaliculus at just ventrally to solenidion. Tarsus III (Fig. 35C) with four dorsal setae. Tarsus IV (Fig. 35D) with three dorsal setae (one long thick filiform seta on basal claw fossa, one plumose seta on distal claw fossa, one fine filiform seta on anterodorsal surface) and two parambulacral setae (one fine filiform proeuphathidium on posterior surface, one scaliform proeuphathidium on anterior surface).

Male (paratype).

Body size somewhat smaller than that in the female.

Genitoanal region (Fig. 33B) furnished with branched perigenital setae. Subgenital setae two pairs, arranged 2-0. Genital acetabula three pairs. Spermatophorotype very massive. Anal plate partly fused to middle plate. Tarsus IV (Fig. 35E) furnished with three dorsal setae (one long thick filiform seta on basal claw fossa, one plumose seta on distal claw fossa, one plumose seta on anterodorsal surface of claw fossa) and two parambulacral setae (one long plumose proeuphathidium on posterior surface, one scaliform proeuphathidium on anterior surface).

Tritonymph

Idiosoma $304 \mu \mathrm{m}$ long, $208 \mu \mathrm{m}$ wide, gnathosoma-length/idiosoma-length 0.23 .

Dorsum : AD $100 \mu \mathrm{m}$ long, $104 \mu \mathrm{m}$ wide, strongly protruded anteriorly, truncated posteriorly. OC $88 \mu \mathrm{m}$ long. PD $124 \mu \mathrm{m}$ long, $106 \mu \mathrm{m}$ wide, convex anteriorly. $\mathrm{AD}$ and PD separated by interval about a half of PD-length.

Venter: All ventral plates separated. AE $74 \mu \mathrm{m}$ long, $184 \mu \mathrm{m}$ wide, furnished with a number of subsurface pores medially as well as along posterior margin, with three aes-ii-adj on each lateral margin. PE $102 \mu \mathrm{m}$ long, furnished with one pes-iii-adj and several subsurface pores along anteroventral margin. A pair of small subsurface pore placed on membranous cuticle medially.

Genitoanal region (Fig. 33C): Genital plate $76 \mu \mathrm{m}$ long, $86 \mu \mathrm{m}$ wide, subtriangular in shape, furnished with two pairs of perigenital and one pair of subgenital setae, bearing a tiny subsurface pore on each lateral margin. Primordial genital slit with three pairs of internal genital acetabula. Anal plate small, nearly truncated anteriorly.

Legs: Leg chaetotaxy of trochanters I-IV, 1-1-2-0; basifemora I-IV, 2-2-2-2 ; telofemora I-IV, 5-5-5-6; genua I-IV, 6-6-4-5; tibiae I-IV, 6-6-5-5. Distinct bipectinate setae on tibiae I-IV : 2-1-1-1.

Protonymph

Idiosoma $228 \mu \mathrm{m}$ long, $148 \mu \mathrm{m}$ wide, gnathosoma-length/idiosoma-length 0.23 .

Dorsum : AD $68 \mu \mathrm{m}$ long, $70 \mu \mathrm{m}$ wide, protruded posteriorly. PD $92 \mu \mathrm{m}$ long, $72 \mu \mathrm{m}$ wide. OC $58 \mu \mathrm{m}$ long.

Venter: AE $60 \mu \mathrm{m}$ long, $126 \mu \mathrm{m}$ wide, without aes-ii-adj. PE $70 \mu \mathrm{m}$ long, without pes-iii-adj.

Genitoanal region (Fig. 33D): Genital plate $74 \mu \mathrm{m}$ long, $54 \mu \mathrm{m}$ wide, furnished with 
primordial genital slit and one pair of internal genital acetabula. Genital seta absent.

Legs: Femur of leg IV without dividing into basifemur and telofemur. Leg chaetotaxy of trochanters I-IV, 1-1-1-0; basifemora (femur of leg IV) I-IV, 2-2-1-2 ; telofemora I-III, 3-3-2; genua I-IV, 4-4-3-3; tibiae I-IV, 5-5-5-5. Distinct bipectinate setae on tibiae I-IV : $2-1-0-0$.

Morphological variation and abnormality

The number of setae aes-ii-adj on each side of idiosoma in adults varies from three to four. The number of the perigenital setae on each side of the genital foramen varies from 14 to 25 in the male. The leg chaetotaxy of adult specimens varies as follows: Trochanters I -IV, 1-1-1-0 ; basifemora I-IV, 2-3-2-2 ; telofemora I-IV, $(6,7)-(7,8)-(5,6)-(4,5,6,7)$; genua IIV, $(5,6)-(5,6)-(3,4)-(4,5,6)$; tibiae I-IV, $6-6-5-(5,6)$. One specimen has bipectinate setae of tibiae I-IV : 2-1-1-2.

\section{Remarks}

Rhombognathus dissociatus is unique in the following character states : 1) anterior dorsal plate strongly protruded anteriorly, 2) the venter of the female is covered with three ventral plates (right and left posterior epimeral plate and genital plate is fused into single plate in the female), 3) only two pairs of perigenital setae present in the female, 4) the leg chaetotaxy is distinctive in having trochanters I-IV with $1-1-2-0$ setae.

On the notation of morphological variation and abnormality in the original description (Abé, 1990b, p. 528), the author noted "Trochanters I-IV, $(6,7)-(7,8)-(5,6)-(4,5,6,7)$." This description, however, is erroneous, and "Trochanters I-IV" should be corrected to "Telofemora I-IV".

Habitat-Intertidal zone: Algae - Enteromorpha compressa, E. intestinalis on gravels, Sargassum thunbergii, S. confusum, S. fulvellum, S. sagamianum, Sargassum sp., Lomentaria hakodatensis, Cystoseira hakodatensis, Neorhodomela aculeata, Dictyopteris divaricata, Rhodymenia palmata, Coccophora longsdorfii, Zostera marina, Polysiphonia sp., Corallina sp. on ledge and in tide pool. Polychaeta - Pseudopotamilla occelata in tide pool. Mussels - Mytilus edulis, Septifer virgatus on ledge. Boulders. Coarse sandy sediment.

Distribution in Hokkaido-Teuri Island, Atsuta, Shukutsu, Oshoro, Tomari, Tateura, Kikonai, Muroran, Sôya.

\section{Rhombognathus ezoensis Abé, 1990 \\ [Japanese name: Ezo-kaisoudani]}

(Figs. 36-39)

Rhombognathus ezoensis Abé, 1990b, 529-535, figs. 9-12.

Specimens examined. One female (paratype), on Sargassum thunbergii on exposed ledge at low tide, intertidal, Kikonai, Japan Sea coast of Hokkaido, 16.v.1987. H. Abé coll. ; 1 male (paratype), on Corallina sp. at $0.1 \mathrm{~m}$ depth in tide pool, intertidal, Mitsuishi, Pacific coast of Hokkaido, 8.xii. 1988, H. Abé coll.; 1 tritonymph and 1 deutonymph (paratypes), on Sargassum sp. on boulder at $0.2 \mathrm{~m}$ depth at high tide, intertidal, Oshoro (Shamodomari), Japan Sea coast of Hokkaido, 23.vi. 1987, H. Abé coll.

Female (paratype)

Dorsum (Fig. 36A): AD weakly protruded posteriorly. OC furnished with two large corneae and two large polygonal pores. PD furnished with two pairs of setae (ds-iv and ds-v). Venter (Fig. 36B) Epimeral and genital plates fused to form a single plate, and anal plate partly fused. Setae aes-ii-adj located on lateral margins, each consisting of two setae; 


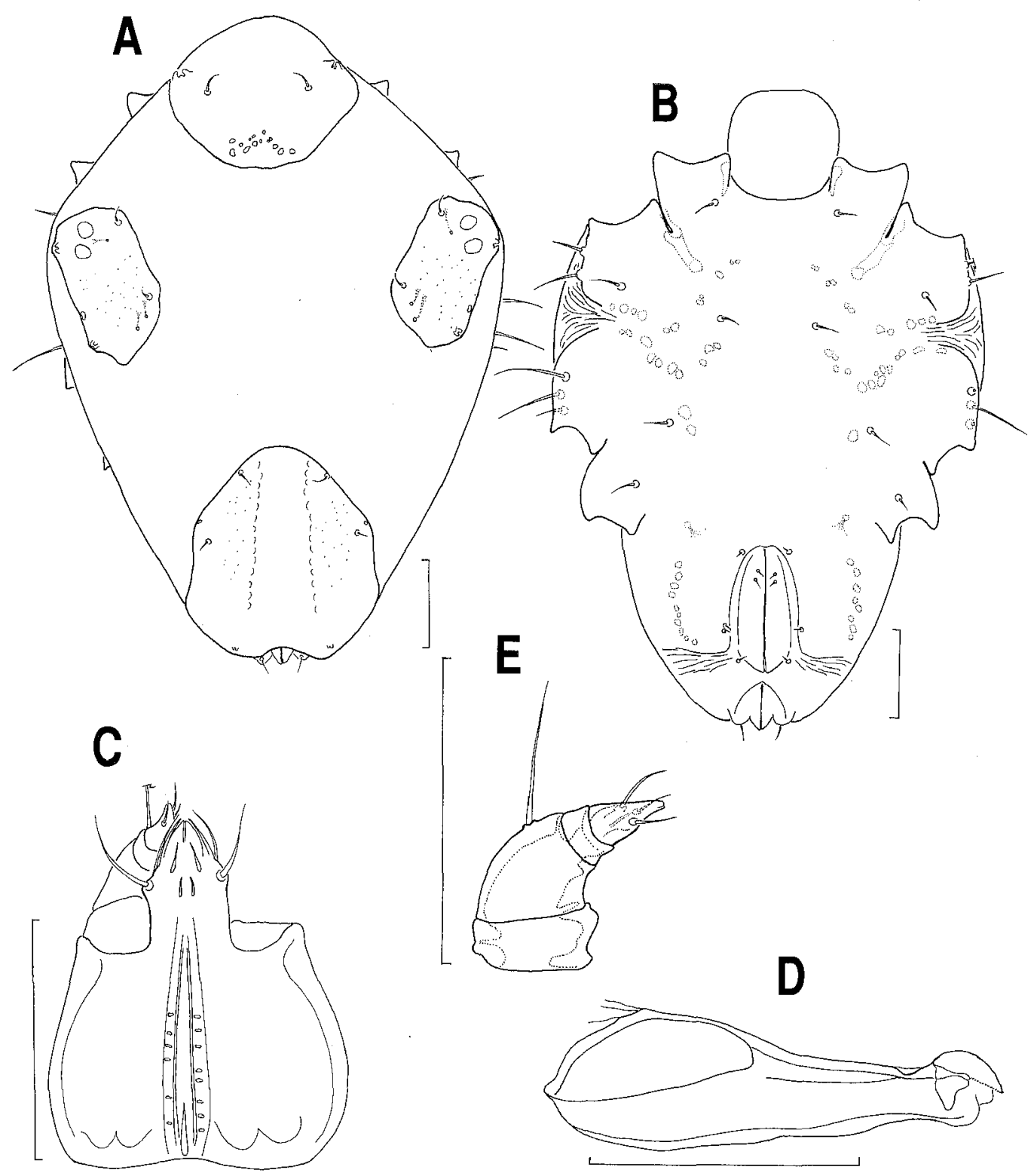

Fig. 36. Rhombognathus ezoensis Abé, 1990, female (paratype). A, idiosoma (Ds) ; B, idiosoma (Vr) ; $\mathrm{C}$, gnathosoma (Vr) (left palp omitted); D, chelicera (L); E, palp (R). Scale bars $=50 \mu \mathrm{m}$.

pes-iii-adj placed dorsolaterally, each consisting of one seta. Genitoanal region (Fig. 37A) slightly incised laterally with membranous cuticle at posterior portion of genital foramen. Genital sclerites with three pairs of genital acetabula. Spermatheca bilobed. Four pairs of short filiform perigenital setae located in the vicinity of genital foramen. Subgenital setae filiform ; two pairs arranged 2-0. Adanal setae placed on anal papilla dorsoproximally.

Gnathosoma (Fig. 36C) : Rostral setae two pairs. Chelicera (Fig. 36D) with movable digit bearing 11-12 minute denticles along dorsal edge. Palp (Fig. 36E) typical form in the genus. 

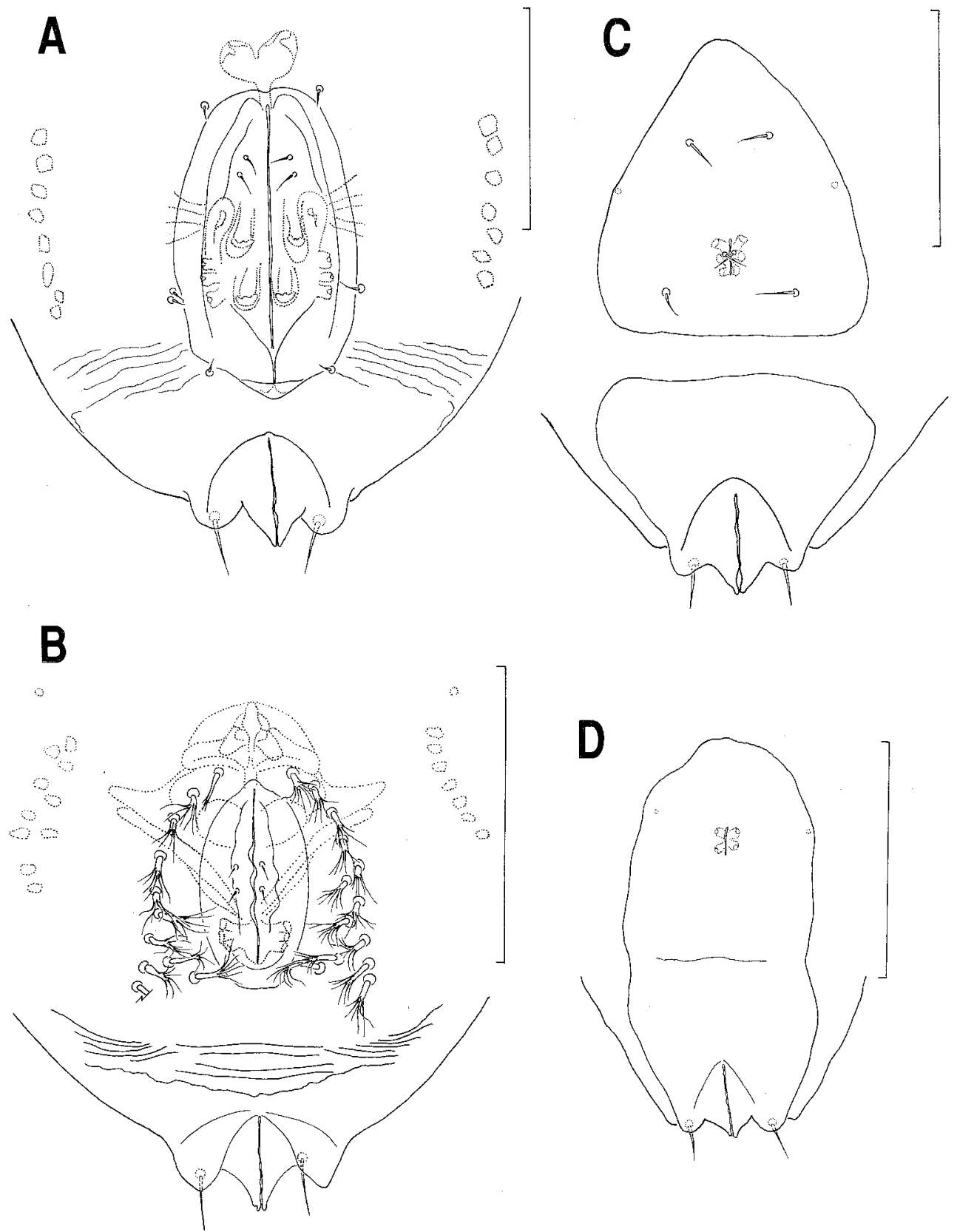

Fig. 37. Rhombognathus ezoensis sp. nov., genitoanal regions. A, female (paratype) ; B, male (paratype) ; C, tritonymph (paratype); D, deutonymph (paratype). Scale bars $=50 \mu \mathrm{m}$.

Legs (Figs. 38A-D) : Lateral claw with palmate accessory process. Solenidion (cf. Figs. $39 \mathrm{~A}, \mathrm{~B}$ ) long bacilliform on posterodorsal surface of claw fossa. Famulus (cf. Fig. 39A) papilliform with fine canaliculus at just ventrally to solenidion. Tarsus III (Fig. 39C) with four dorsal setae. Tarsus IV (Fig. 39D) with three dorsal setae (one long filiform seta on basal 


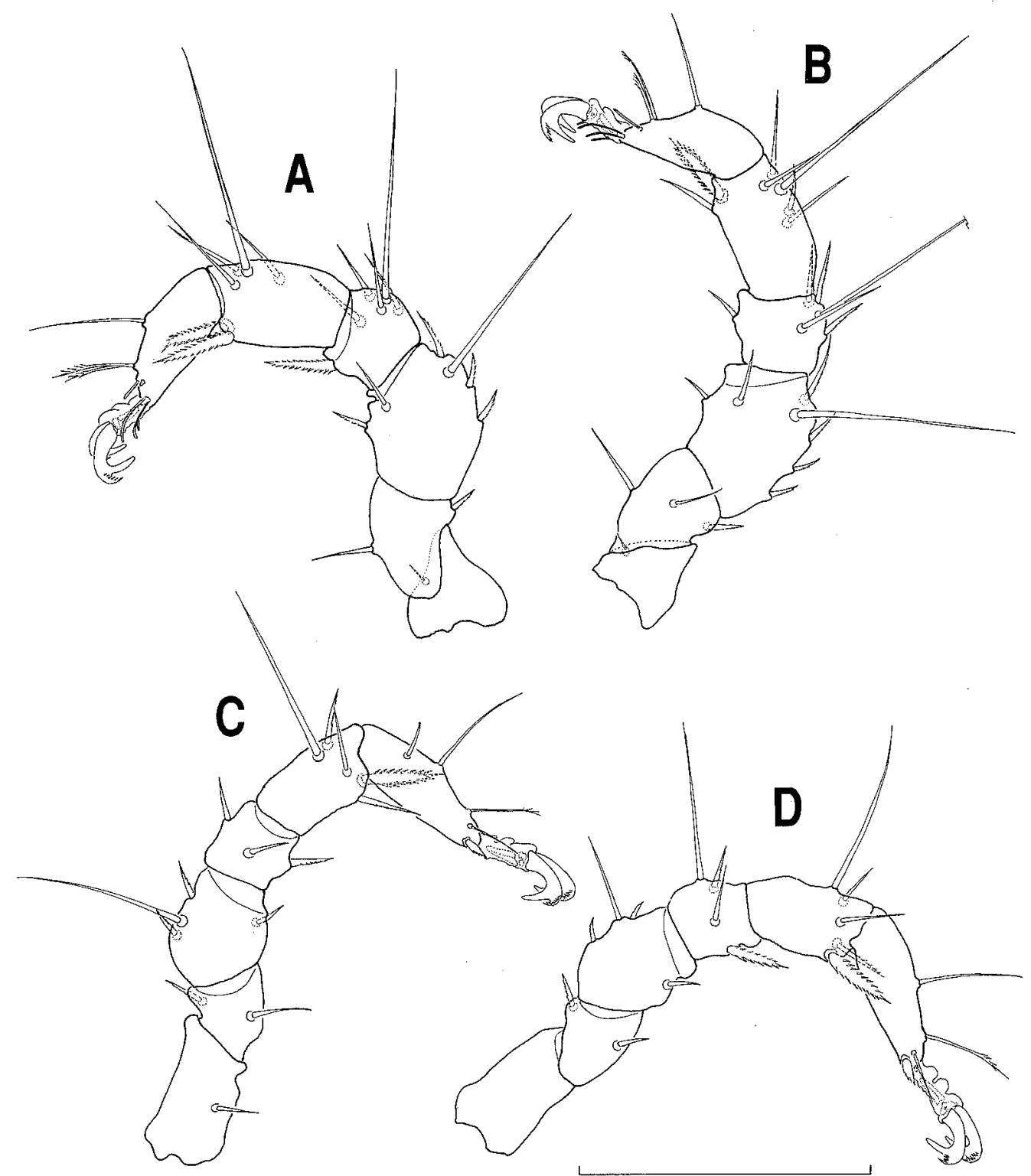

Fig. 38. Rhombognathus ezoensis Abé, 1990, female (paratype). A, leg I (L); B, leg II (L) ; C, leg III (R) ; D, leg IV (R). Scale bar $=100 \mu \mathrm{m}$.

claw fossa, one plumose seta on distal claw fossa, one fine filiform seta on anterodorsal surface) and two parambulacral setae (one single euphathidium on posterior surface, one scaliform proeuphathidium on anterior surface).

Male (paratype)

Genitoanal region (Fig. 37B) furnished with branched perigenital setae. Subgenital setae two pairs on genital sclerites, arranged 2-0. Genital acetabula three pairs. Spermatophor- 


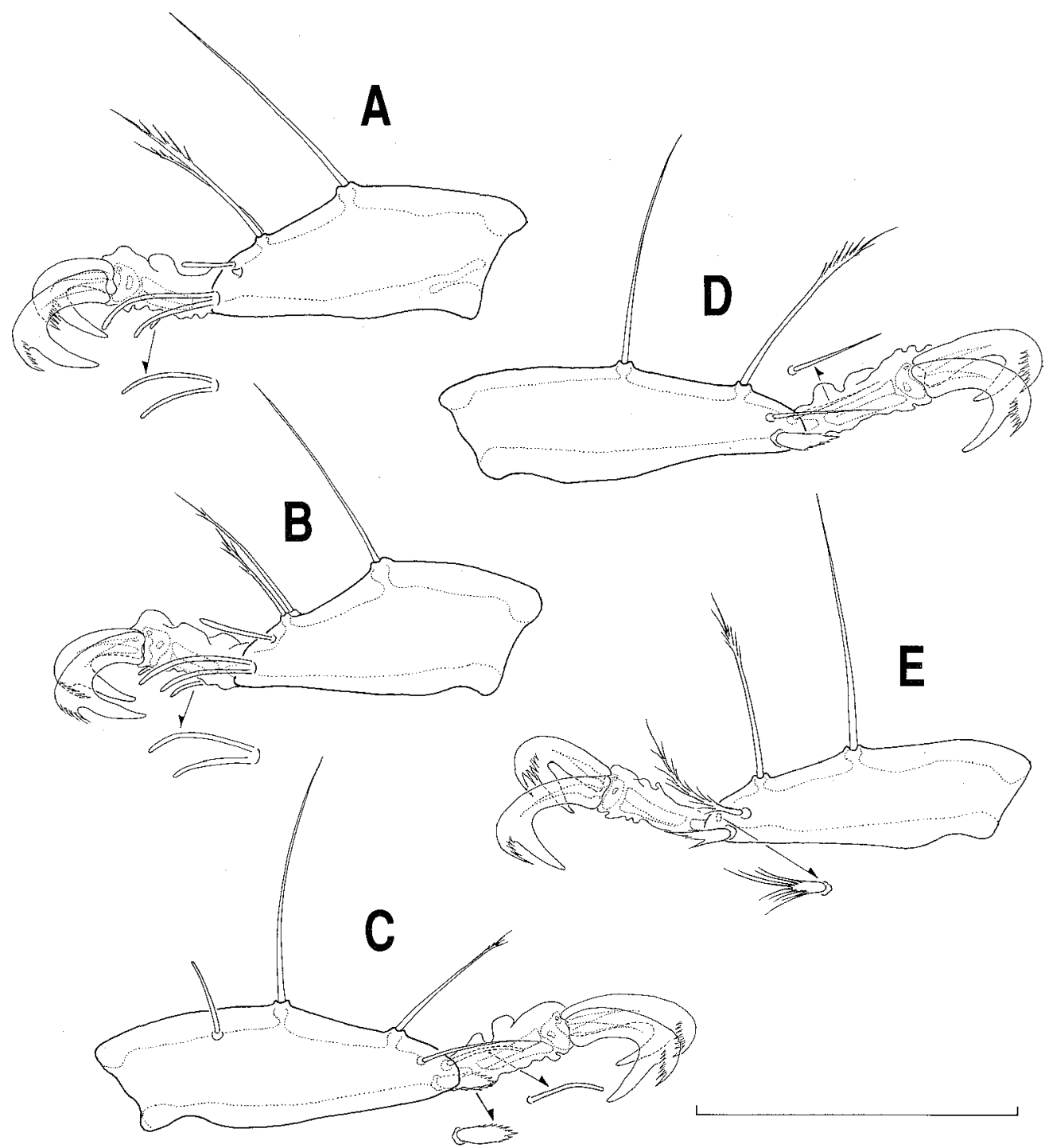

Fig. 39. Rhombognathus ezoensis Abé, 1990, female (paratype). A, tarsus I (L) ; B, tarsus II (L) ; C, tarsus III (L); D, tarsus IV (L). Male (paratype). E, tarsus IV (R). Scale bar $=50 \mu \mathrm{m}$.

otype rhombic. Tarsus IV (Fig. 39E) furnished with three dorsal setae (one long thick filiform seta on basal claw fossa, one plumose seta on distal claw fossa, one delicate plumose seta on anterodorsal surface of claw fossa) and two parambulacral setae (one long plumose proeuphathidium on posterior surface, one scaliform proeuphathidium on anterior surface).

Tritonymph (paratype)

Genital plate (Fig. 37C) bluntly protruded anteriorly, nearly truncated posteriorly, furnished with two pairs of perigenital and one pair of subgenital setae. Primordial genital slit with three pairs of genital acetabula. Anal plate small, nearly truncated anteriorly. 
Deutonymph (paratype)

AE without aes-ii-adj. PE without pes-iii-adj. Genital plate (Fig. 37D) furnished with primordial genital slit and two pairs of internal genital acetabula. Genital seta absent.

Morphological variation and abnormality

The number of setae aes-ii-adj and pes-iii-adj on each side of idiosoma varies from two to three, and zero to one respectively. The number of the perigenital setae on each side of the genital foramen varies from 12 to 14 in the male, three to five in the female. The leg chaetotaxy varies among adult specimens as follows: Trochanters I-IV, $(0,1)-(0,1)-1-0$; basifemora I-IV , 2-(2,3)-2-(1,2) ; telofemora I-IV, $(6,7)-7-(4,5,6)-(3,4,5)$; genua I-IV , $(5,6)-(5,6)$ $-3-4$; tibiae I-IV, $(6,7)-(6,7)-(5,6)-(5,6)$. Dorsoproximal seta on tarsus III is rarely lacking.

\section{Remarks}

Rhombognathus ezoensis is distinguishable from the other congeners by the following character states : 1) dorsal plates separated, 2) two pairs of setae on PD, 3) perigenital setae very short and four pairs in the female, 12-14 branched setae in the male, and 4) accessory process palmate with $6-8$ teeth.

$R$. ezoensis closely resembles $R$. reticulatus Krantz, 1976. $R$. ezoensis, however, is distinctive from the latter by the number of perigenital setae in the female, and leg chaetotaxy.

In the original description (Abé, 1990b, p. 529), the author noted "(AD) without clear dorsal pore." This description, however, is due to an overlooking, and a dorsal pore presents near each lateral margin of AD. In the original description of tritonymph (Abé, 1990b, p. 534), the author noted "Subgenital seta absent." But this description was resulted from a misobservation, and one pair of faint subgenital setae is present near genital slit in the tritonymph. Furthermore, genital plate and anal plate of deutonymph are separated to each other by striated membranous cuticle in the original description (Abé, 1990b, p. 534, fig. 10G), but one paratype deutonymph specimen described in the present paper has fused single genitoanal plate. Unfortunately it is not clear in the present circumstances which condition of genitoanal region of deutonymph is said to be normal.

$R$. ezoensis is widely distributed around Hokkaido and is most abundant everywhere. Its adults are always observed throughout the year. Therefore, this species probably passes multiple generations in a year.

Habitat-Intertidal and subtidal zones: Algae - Enteromorpha compressa, E. intestinalis on gravels, Sargassum fulvellum, S. thunbergii, S. confusum, Sargassum sp., Neorhodomela aculeata, Rhodymenia palmata, Coccophora langsdorfi, Corallina pilulifera, Corallina sp., Lomentaria hakodatensis, Dictyopteris divaricata, Desmarestia ligulata, Fucus evanescens, Cystoseira hakodatensis, Ectocarpus siliculosus, Ulva pertusa in tide pool and on ledge, Zostera marina, Phyllospadix iwatensis in tide pool, Agarum cribrosum at subtidal zone. Mussels Mytilus edulis, Septifer virgatus on tetrapod, ledge and flat. Barnacles - Balanus cariosus on tetrapod and ledge. Boulders. Coarse sandy sediment.

Distribution in Hokkaido-Wakkanai, Bakkai, Horodomari (Rebun Island), Kabukai (Rebun Island), Kabuka (Rebun Island), Oshidomari (Rishiri Island), Nozuka (Rishiri Island), Shosanbetsu, Teuri Island, Yagishiri Island, Rumoi, Mashike, Hamamasu, Atsuta, Shukutsu, Oshoro, Tomari, Tateiwa, Hutoro, Aonae (Okushiri Island), Tateura, Kaminokuni, Shirakami, Kikonai, Usujiri, Usu, Date, Muroran, Tomakomai, Shizunai, Mitsuishi, Samani, Erimo, Hiroo, Kushiro, Nakanose, Daikoku Island, Lake Akkeshi, Tôbai, Rausu, Aidomari, Utoro, Oshinkoshin, Masuura, Tokoro, Sakaeura, Kimuaneppu, Barou, Monbetsu, Esashi, Ômisaki, Sôya. 


\section{[Japanese name: Mayoi-kaisoudani]}

(Figs. $40-42$ )

Type series. Holotype: Female, on Gymnogongrus flabelliformis at a depth of $0.1 \mathrm{~m}$ in tide pool, intertidal, Oshoro (Nekodomari), Japan Sea coast of Hokkaido, 30.viii.1988, H. Abé coll.

Female (holotype)

Idiosoma $322 \mu \mathrm{m}$ long, $196 \mu \mathrm{m}$ wide. Color in life dark green.

Dorsum (Fig. 40A) : Dorsal plate ornamented with reticulated panels (Fig. 40C), and partly with fine canaliculi. AD and PD separated by interval of approximately AD-length. AD $84 \mu \mathrm{m}$ long, $84 \mu \mathrm{m}$ wide, rounded posteriorly, ornamented with weak areolation posteriorly, with a dorsal pore near each lateral margin. OC $84 \mu \mathrm{m}$ long, extending anteriorly to level of the posterior margin of AD, reaching posteriorly at level of insertion of leg III, furnished with two small corneae and two polygonal pores, bearing one tiny pore-like structure on lateral margin, one maze-like subsurface pore medially to anterior cornea, and two tiny subsurface pores near each posteromedial margin. Areolation indistinct. PD $148 \mu \mathrm{m}$ long, $102 \mu \mathrm{m}$ wide, furnished with a small subsurface pore on anterolateral margin, and with dorsal pore on posterior margin on each side. Costae weak.

Chaetotaxy of dorsal region: Dorsal setae short. Setae ds-i on AD, somewhat longer than the others; ds-ii and ds-iii each on OC; ds-iv on PD, near anterolateral margin. Setae ds-v absent.

Venter (Fig. 40B) : Epimeral and genitoanal plates fused to form a single plate. Ventral plates are entirely reticulated with weak porous panels. Epimeral region furnished with several subsurface pores medially, and with epimeral pore between insertions of leg I and leg II on each side. Lateral incisions not clear.

Chaetotaxy of epimeral region: Setae aes-i located posteriorly to camerostome ; aes-iilat placed near lateral margin; aes-ii-v placed most medially; aes-ii-adj located on dorsolateral margins, each consisting of one seta ; pes-iii-lat placed dorsally on posterior epimeral region ; pes-iii-v near lateral margins ; pes-iv-a placed medially at level of slightly anterior to insertion of leg III ; pes-iv-p located at level anterior to insertion of leg IV; pes-iii-adj located dorsolaterally, each consisting of one seta.

Genitoanal region (Fig. 40D): Genitoanal region without distinct lateral incisions. Genital foramen $74 \mu \mathrm{m}$ long, $58 \mu \mathrm{m}$ wide, occupying from level slightly posterior to insertion of leg IV to level anterior to anal foramen. Genital sclerites band-like, with three pairs of internal genital acetabula. Spermatheca indistinct.

Chaetotaxy of genitoanal region: Five pairs of filiform perigenital setae located at each side of genital foramen as arranged in Fig. 40D. Subgenital setae filiform; two pairs on genital sclerites, arranged 2-0. Adanal setae very fine, placed dorsally on anal papilla.

Gnathosoma (Fig. 41A) : $78 \mu \mathrm{m}$ long, $62 \mu \mathrm{m}$ wide, gnathosoma-length/idiosoma-length 0 . 24. Base, length/width 0.83 . Rostrum $28 \mu \mathrm{m}$ long, nearly lanceolate, not reaching to level of distal end of palp. Rostral setae two pairs as follows: Proximal pair long and robust, at swollen point ; distal pair short, at just anterior to proximal pair. Chelicera (Fig. 41B) with basal segment $76 \mu \mathrm{m}$ long, and movable digit $16 \mu \mathrm{m}$ long, bearing 11-13 denticles along dorsal edge. Fixed digit extending distally to mid level of movable digit. Palp (Fig. 41C) $48 \mu \mathrm{m}$ long; $\mathrm{P}-1$ short and cylindrical ; $\mathrm{P}-2$ longest, with a long filiform seta distidorsally ; $\mathrm{P}-3$ short and cylindrical; $\mathrm{P}-4$ conical, with two filiform and one blade-like setae intermediately.

Legs (Figs. $42 \mathrm{~A}-\mathrm{D}$ ) : Length of legs I, II, III, IV $=210,214,224,222 \mu \mathrm{m}$ respectively. Ornamentation indistinct. Lateral claw with palmate accessory process, bearing seven to nine delicate teeth.

Leg chaetotaxy as follows: Trochanters I-IV, 1-1-1-0; basifemora I-IV, 2-2-2-2 ; telofemora I-IV, 6-7-4-4; genua I-IV, 5-5-3-3; tibiae I-IV, 5-5-5-5. As for large 


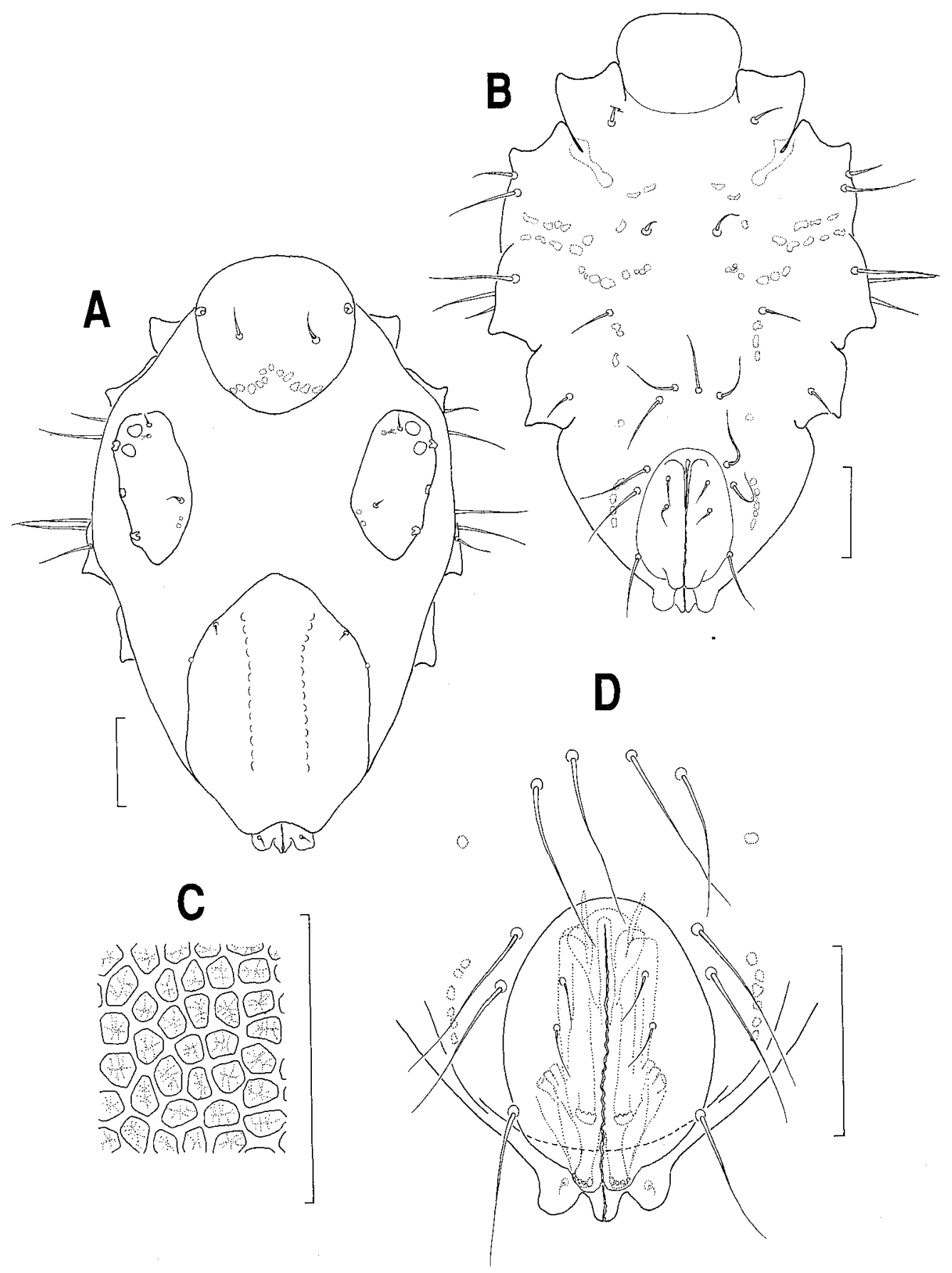

Fig. 40. Rhombognathus incertus sp. nov., female (holotype). A, idiosoma (Ds) ; B, idiosoma (Vr); C, panels on $\mathrm{PD} ; \mathrm{D}$, genitoanal region. Scale bars $=50 \mu \mathrm{m}$. 


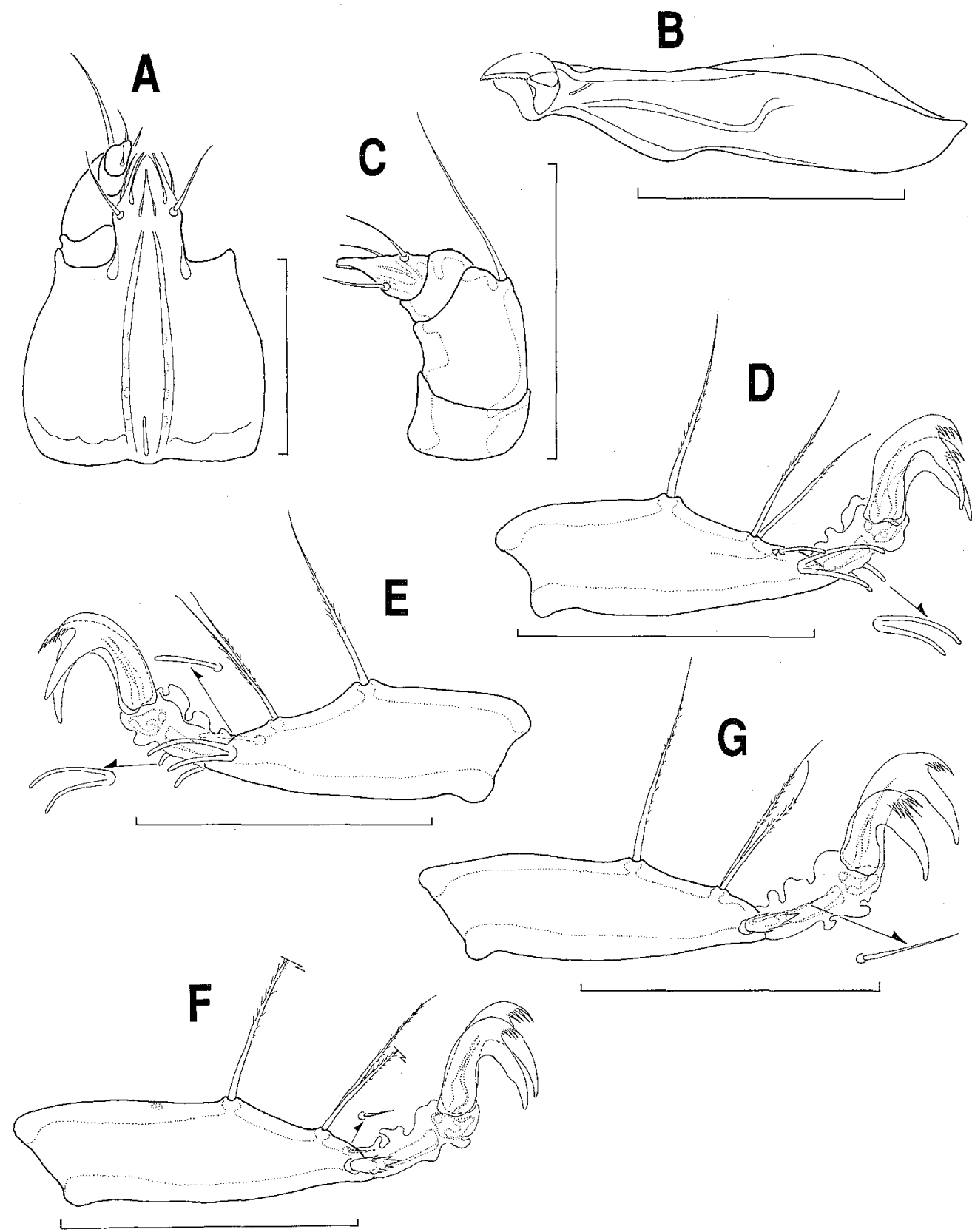

Fig. 41. Rhombognathus incertus sp. nov., female (holotype). A, gnathosoma (Vr) (left palp omitted) ; B, chelicera (L) ; C, palp (L) ; D, tarsus I (R) ; E, tarsus II (R) ; F, tarsus III (L); G, tarsus IV (L). Scale bars $=50 \mu \mathrm{m}$. 


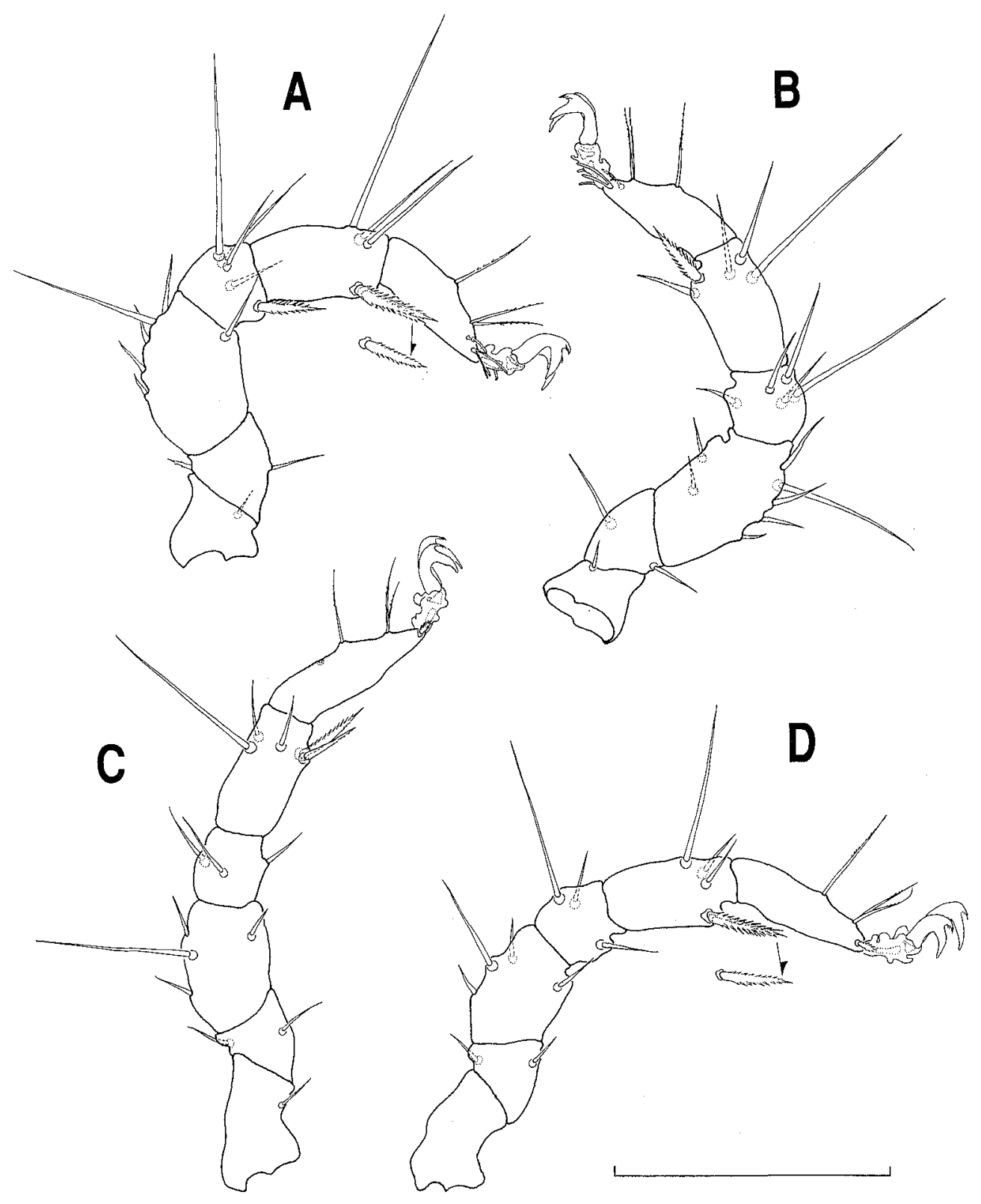

Fig. 42. Rhombognathus incertus sp. nov., female (holotype). A, leg I (R) ; B, leg II (R) ; C, leg III (L); D, leg IV (L). Scale bar $=100 \mu \mathrm{m}$.

bipectinate setae: Genua I-IV, 1-0-0-0; tibiae I-IV, 2-1-1-2 (one seta is less pectinated). Tarsus I (Fig. 41D) with three dorsal setae, one solenidion, one famulus, and four parambulacral setae (paired doublet euphathidia). Solenidion long bacilliform on posterodorsal surface of claw fossa. Famulus papilliform with fine canaliculus at just proximally to solenidion. Tarsus II (Fig. 41E) with three dorsal setae, one solenidion, and four parambulacral setae. Solenidion long bacilliform on posterodorsal surface of claw fossa. Tarsus III (Fig. 41F) with 
four dorsal setae and two parambulacral setae (one single euphathidium on posterior surface, one scaliform proeuphathidium on anterior surface). Tarsus IV (Fig. 41G) with three dorsal setae (one long faintly plumose seta on basal claw fossa, two weakly plumose seta on distal claw fossa) and two parambulacral setae (one fine filiform euphathidium on posterior surface, one scaliform proeuphathidium on anterior surface).

\section{Remarks}

Rhombognathus incertus is placed in a group characterized by having five perigenital setae in the female. $R$. incertus is distinguishable from the sympatric $R$. sinensis Bartsch, 1990 and other closely related species by having clear reticulations on dorsal plates, AD with round posterior margin, and genua I-IV with 1-0-0-0 bipectinate seta. The clearly pectinated bipectinate seta on the genu is shared with $R$. cetratus Bartsch, 1974b, R. felicis Newell, 1984, $R$. longiscutatus Bartsch, 1977, and R. novaezelandicus Bartsch, 1985 (unclear, probably 1-0$0-0)$. However, $R$. incertus differs from these congeners by having the palmate type accessory process and the telofemora I-IV with 6-7-4-4 setae.

The specific epithet is derived from the incertitude of discriminative characters.

Habitat-Intertidal zone: Algae - Gymnogongrus flabelliformis in tide pool.

Distribution in Hokkaido-Oshoro.

\section{Rhombognathus leurodactylus Krantz, 1976}

[Japanese name: Subeyubi-kaisoudani]

(Figs. 43-45)

Rhombognathus leurodactylus Krantz, 1976, 243-246, figs. 1-8.

Specimens examined. One female, on Enteromorpha intestinalis on gravels at a depth of $0.1 \mathrm{~m}$, intertidal, Shizunai, Pacific coast of Hokkaido, 22.v.1989, H. Abé coll. ; 4 females and 3 males, coarse sand on tidal line, intertidal, Oshoro (Shirikoshi), Japan Sea coast of Hokkaido, 22.iii.1989, H. Abé coll. ; 1 male, locality same as above, 6.iii.1989, H. Abé coll. ; 1 male, locality same as above, 13.iv.1989, H. Abé coll.

Female

Idiosoma $328 \mu \mathrm{m}$ long, $180 \mu \mathrm{m}$ wide. Color in life dark green.

Dorsum (Fig. 43A) : Dorsal plates weakly sclerotized. AD protruded posteriorly, ornamented with weak areolation posteriorly. OC furnished with two corneae and two polygonal pores. Dorsal setae short. PD furnished with two pairs of setae (ds-iv and ds-v) near anterolateral margin.

Venter (Fig. 43B) : Epimeral and genital plates fused to form a single plate. Anal plate isolated at distal end of venter. Setae aes-ii-adj located on lateral margins, each consisting of two or three setae; pes-iii-adj placed dorsolaterally, each consisting of one seta. Genital region (Fig. 43C) surrounded posteriorly with membranous cuticle. Genital foramen completely separated from anal foramen by wide membranous area. Genital sclerites band-like, with three pairs of genital acetabula. Spermatheca bilobed. Three pairs of filiform perigenital setae located at genitoanal region. Subgenital setae filiform; two pairs on genital sclerites, arranged 2-0. Adanal setae placed on anal papilla dorsally.

Gnathosoma (Fig. 44A) : Rostral setae two pairs. Chelicera (Fig. 44B) with movable digit bearing about 12 minute denticles along dorsal edge. Palp (Fig. 44C) typical form in the genus.

Legs (Figs. 45A-D) : Lateral claw smooth, without accessory process. Solenidion (cf. Figs. 44D,E) long bacilliform on posterodorsal surface of claw fossa. Famulus (cf. Fig. 44D) papilliform with fine canaliculus at just ventrally to solenidion. Tarsus III (Fig. 44F) with four dorsal setae. Tarsus IV (Fig. 44G) with three dorsal setae (one long filiform seta on basal 

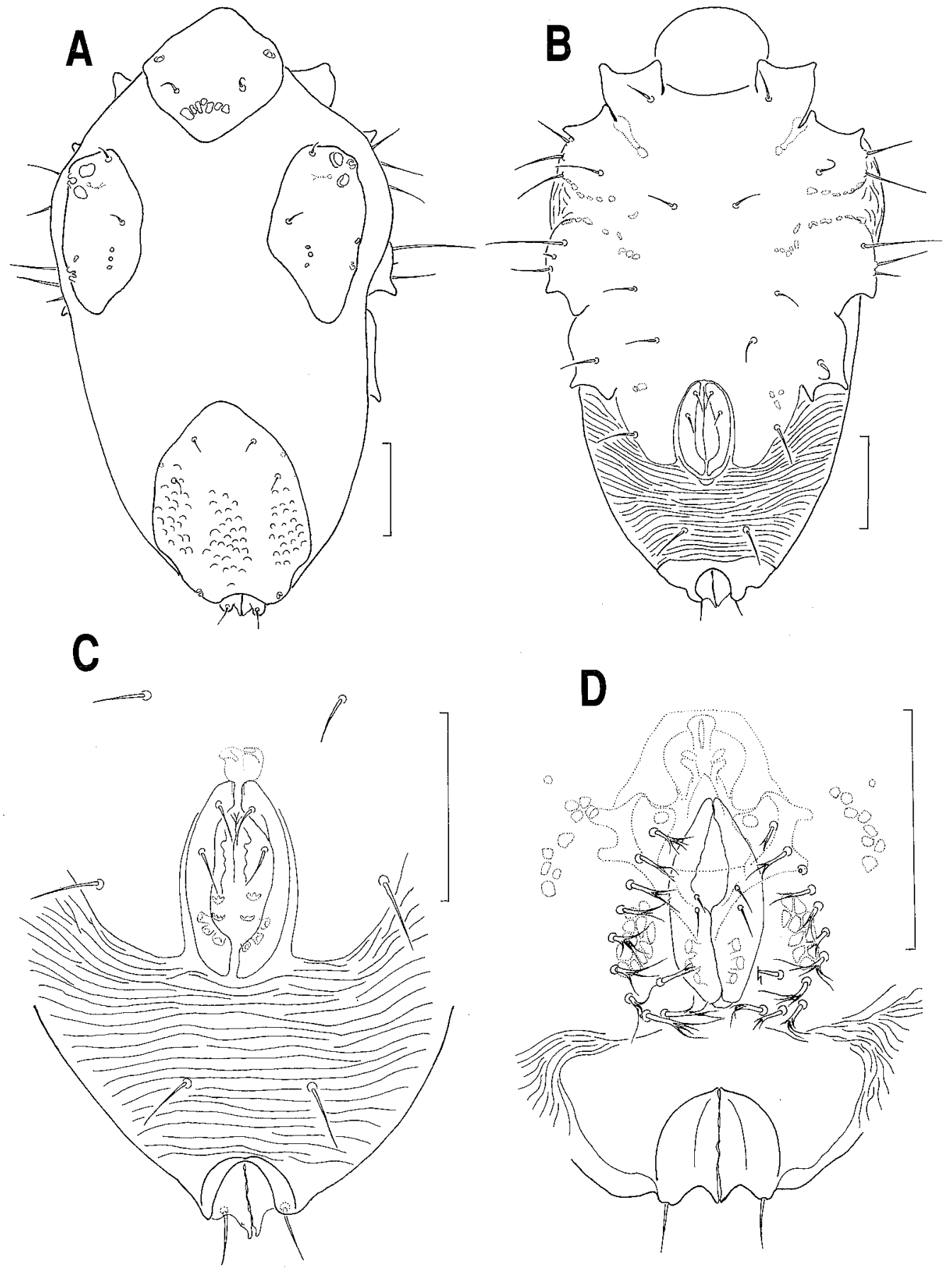

Fig. 43. Rhombognathus leurodactylus Krantz, 1976, female. A, idiosoma (Ds); B, idiosoma (Vr) ; C, genitoanal region. Male. D, genitoanal region. Scale bars $=50 \mu \mathrm{m}$. 


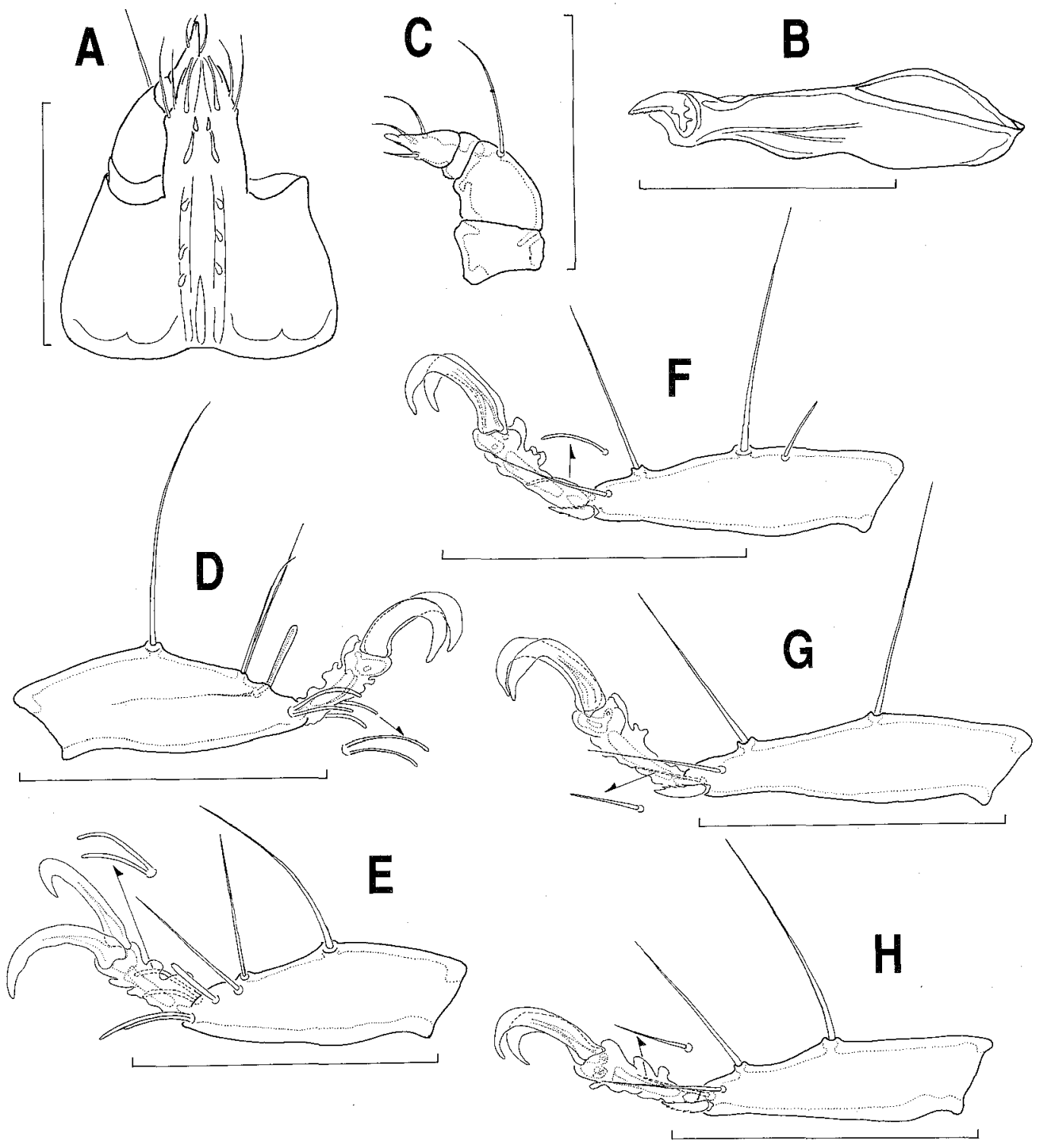

Fig. 44. Rhombognathus leurodactylus Krantz, 1976, female. A, gnathosoma (Vr) (left palp omitted) ; B, chelicera (R); C, palp (L); D, tarsus I (L); E, tarsus II (L); F, tarsus III (R); G, tarsus IV (R). Male. $\mathrm{H}$, tarsus IV (R). Scale bars $=50 \mu \mathrm{m}$.

claw fossa, one filiform seta on distal claw fossa, one fine filiform seta on anterodorsal surface) and two parambulacral setae (one filiform euphathidium on posterior surface, one scaliform proeuphathidium on anterior surface).

Male

Genitoanal region (Fig. 43D) incised laterally with membranous cuticle, bearing branched perigenital setae. Subgenital setae two pairs, arranged 2-0. Genital acetabula three pairs. 


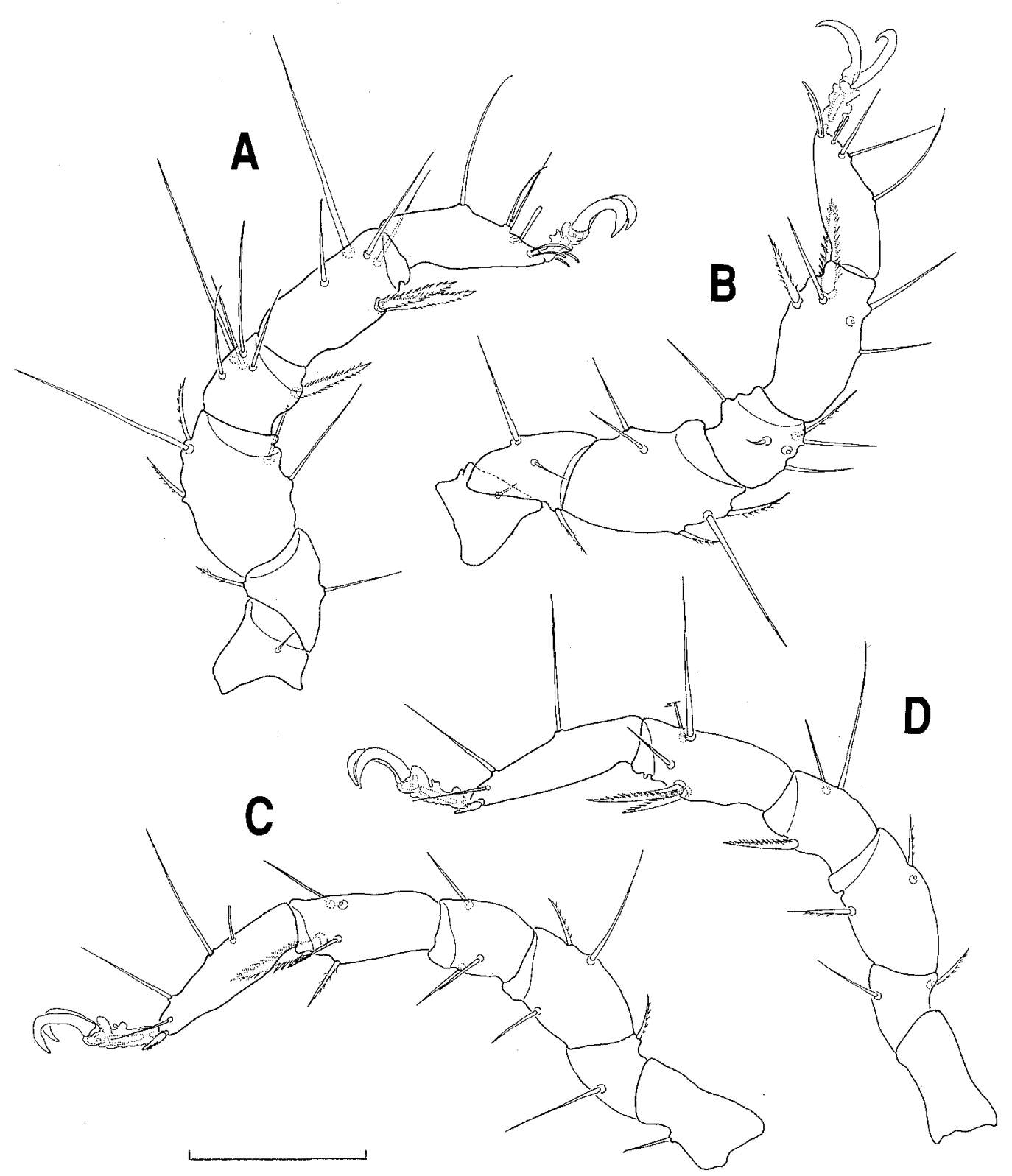

Fig. 45. Rhombognathus leurodactylus Krantz, 1976, female. A, leg I (L); B, leg II (L) ; C, leg III (R) ; D, leg IV (R). Scale bar $=100 \mu \mathrm{m}$.

Spermatophorotype rhombic. Tarsus IV (Fig. 44H) similar to that in the female.

Morphological variation and abnormality

The size range of the idiosoma, gnathosoma, and legs I-IV as follows.

Female $(\mathrm{n}=5)$. Idiosoma-length : $316-348 \mu \mathrm{m}$, -width : $152-200 \mu \mathrm{m}$; gnathosoma-length : 62-76 $\mu \mathrm{m}$, -width : 56-68 $\mu \mathrm{m}$; leg-length : Leg I, 186-200 $\mu \mathrm{m}$; leg II, 180-196 $\mu \mathrm{m}$; leg III, 176 $-204 \mu \mathrm{m}$; leg IV, 182-214 $\mu \mathrm{m}$. 
Male $(\mathrm{n}=5)$. Idiosoma-length : 288-316 $\mu \mathrm{m}$, -width : 160-180 $\mu \mathrm{m}$; gnathosoma-length : 66-70 $\mu \mathrm{m}$, -width : $56-62 \mu \mathrm{m}$; leg-length : Leg I, 170-192 $\mu \mathrm{m}$; leg II, 170-194 $\mu \mathrm{m}$; leg III, 168 $-196 \mu \mathrm{m} ;$ leg IV, $186-198 \mu \mathrm{m}$.

The leg chaetotaxy varies among adult specimens $(\mathrm{n}=10)$ as follows : Trochanters $\mathrm{I}-\mathrm{IV}$, 1-1-1-(0,1) ; basifemora I-IV, 2-3-2-(1,2) ; telofemora I-IV, $(4,5)-(4,5)-3-(3,4)$; genua I-IV, 6 $-(5,6)-3-3$; tibiae I-IV , 6-6-5-5. One of two bipectinate setae of tibia IV is less pectinated in some specimens.

The number of setae aes-ii-adj varies from one to three on each side of epimeral region. The number of the perigenital setae on each side of the genital foramen varies from 10 to 17 in the male. One specimen has three dorsal setae on right OC.

\section{Remarks}

Rhombognathus leurodactylus is originally described by Krantz (1976) from the sandy sediment of Schooner Creek, North Pacific coast of the United States. The adult specimens from Hokkaido, northern Japan, accord well with the original description except for the smaller body size (corresponding condition of North American specimens in parentheses): 316-348 (359-411) $\mu \mathrm{m}$ in the female, 288-316 (333-364) $\mu \mathrm{m}$ in the male.

In almost all significant taxonomic characters of $R$. leurodactylus showed nearly identical character states with $R$. subtilis Bartsch, 1975. But $R$. leurodactylus is discernible from $R$. subtilis by the conformation of dorsal plates in adults, and branched subgenital setae in the tritonymph.

$R$. leurodactylus also resembles $R$. lionyx Trouessart, 1899. The present species, however, differs from the latter by having completely smooth lateral claws, two large bipectinate setae on tibia IV, and only one seta on trochanter III rather than two as in $R$. lionyx.

$R$. leurodactylus has been considered to be a psammophilous species (Krantz, 1976), because it has not been known from habitats other than sand. In the present study, however, this species was discovered from several kinds of algae and mussels as well as from sandy sediment.

Habitat-Intertidal zone: Algae - Enteromorpha intestinalis on gravels, Corallina pilulifera, Fucus evanescens, Coccophora langsdorfii in tide pool. Mussels - Mytilus edulis on flat. Coarse sandy sediment.

Distribution in Hokkaido-Oshoro, Tomari, Shizunai, Erimo, Kushiro, Aininkappu, Utoro, Sôya.

\section{Rhombognathus medialis sp. nov.}

[Japanese name: Uchige-kaisoudani]

(Figs. 46-48)

Type series. Holotype: Female, coarse sand on tidal line, intertidal, Daikoku Isl., Pacific coast of Hokkaido, 3.vi.1988, H. Abé coll. Allotype: Male, data same as the holotype. Paratypes: 2 females and 1 male, data same as the holotype; 3 females, coarse sand at a depth of $0.3 \mathrm{~m}$, intertidal, Oshoro (Ponshoro), Japan Sea coast of Hokkaido, 13.iv.1989, H. Abé coll.

Female (holotype)

Idiosoma $360 \mu \mathrm{m}$ long, $232 \mu \mathrm{m}$ wide. Color in life dark green.

Dorsum (Fig. 46A) : Dorsal plates ornamented with clear panels, and partly with fine canaliculi. $\mathrm{AD}$ and $\mathrm{PD}$ separated by interval approximately two times as long as AD-length. AD $78 \mu \mathrm{m}$ long, $86 \mu \mathrm{m}$ wide, protruded posteriorly, ornamented with weak areolation posteriorly and a dorsal pore near each lateral margin. OC $98 \mu \mathrm{m}$ long, extending anteriorly to level slightly posterior to posterior margin of $\mathrm{AD}$, reaching posteriorly at level posterior to 


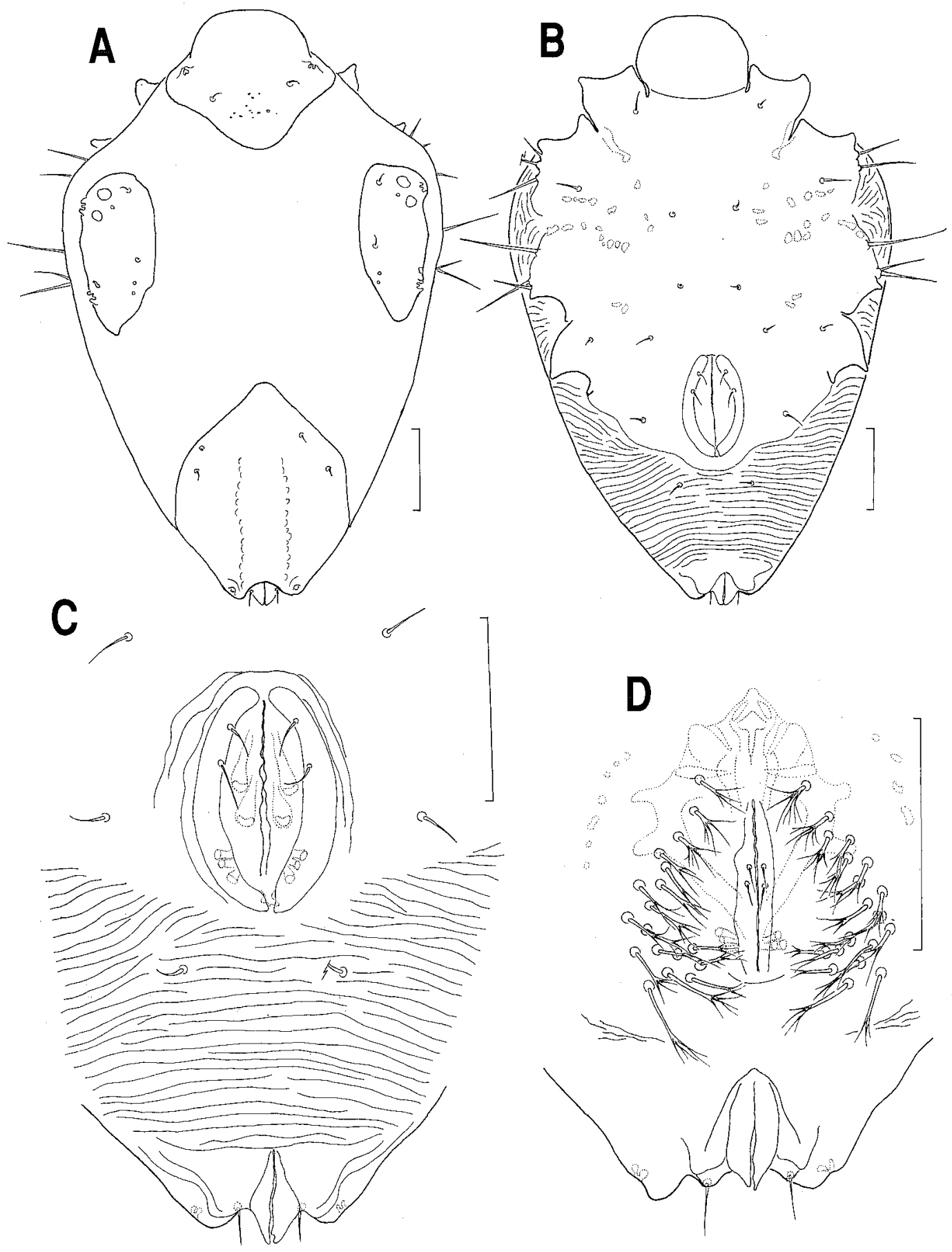

Fig. 46. Rhombognathus medialis sp. nov., female (holotype). A, idiosoma (Ds) ; B, idiosoma (Vr) ; C, genitoanal region. Male (allotype). D, genitoanal region. Scale bars $=50 \mu \mathrm{m}$. 

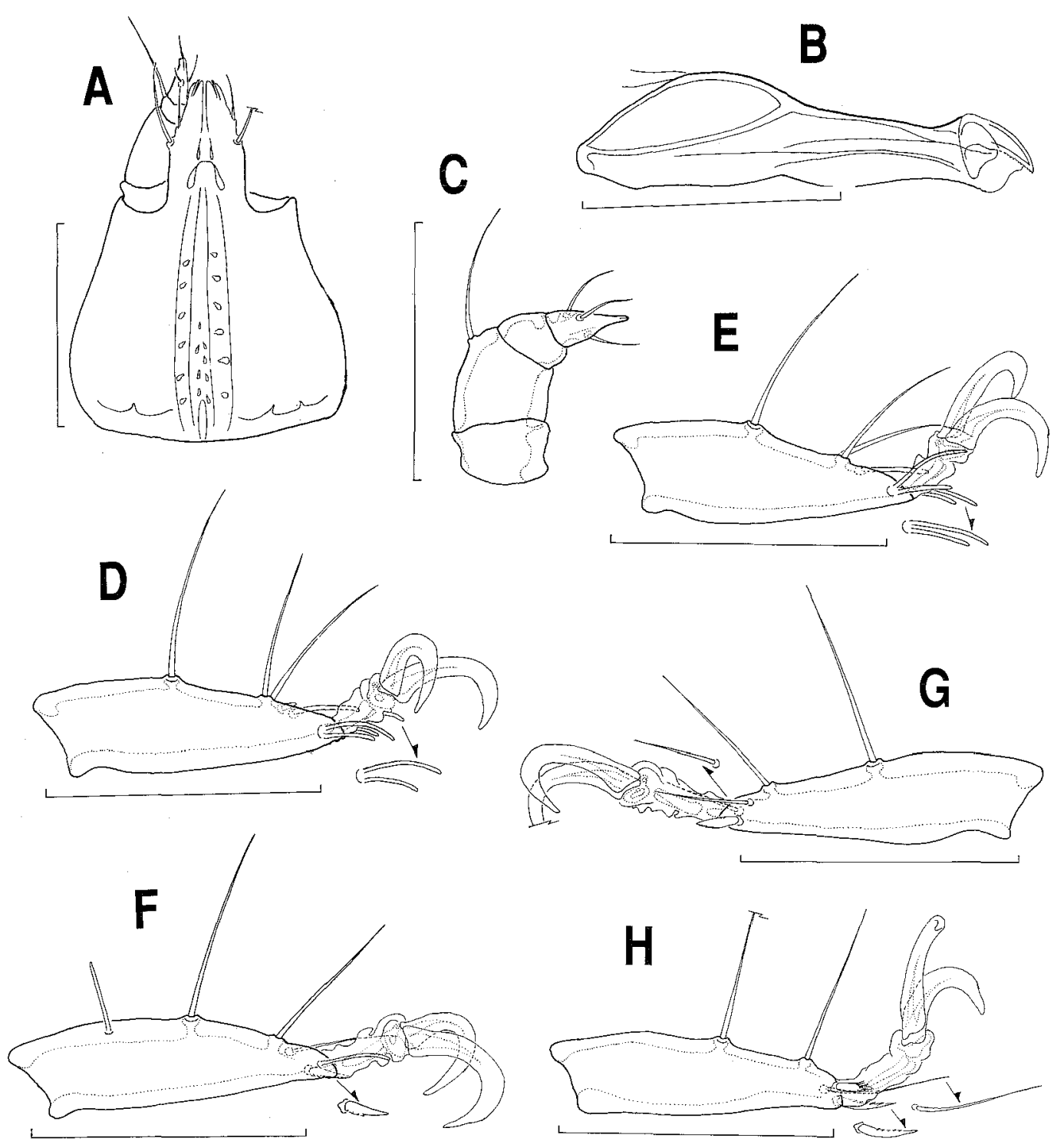

Fig. 47. Rhombognathus medialis sp. nov., female (holotype). A, gnathosoma (Vr) (left palp omitted); B, chelicera (L) ; C, palp (L) ; D, tarsus I (L); E, tarsus II (L); F, tarsus III (R); G, tarsus IV (R). Male (allotype). H, tarsus IV (R). Scale bars $=50 \mu \mathrm{m}$.

insertion of leg III, furnished with two corneae and two polygonal pores, bearing one tiny pore-like structure anteriorly to posterior pore, one maze-like subsurface pore medially to corneae, and two tiny subsurface pores near posteromedial margin. Areolation indistinct. PD $122 \mu \mathrm{m}$ long, $100 \mu \mathrm{m}$ wide, reaching anteriorly to level of insertion of leg IV, strongly protruded at the both sides of terminal end, furnished with a dorsal pore on posterior margin on each side. Costae inconspicuous.

Chaetotaxy of dorsal region: Dorsal setae short. Setae ds-i on AD; ds-ii each on OC near anterior margin; ds-iii each on $\mathrm{OC}$ near medial margin; ds-iv and $\mathrm{ds}-\mathrm{v}$ on $\mathrm{PD}$, near 

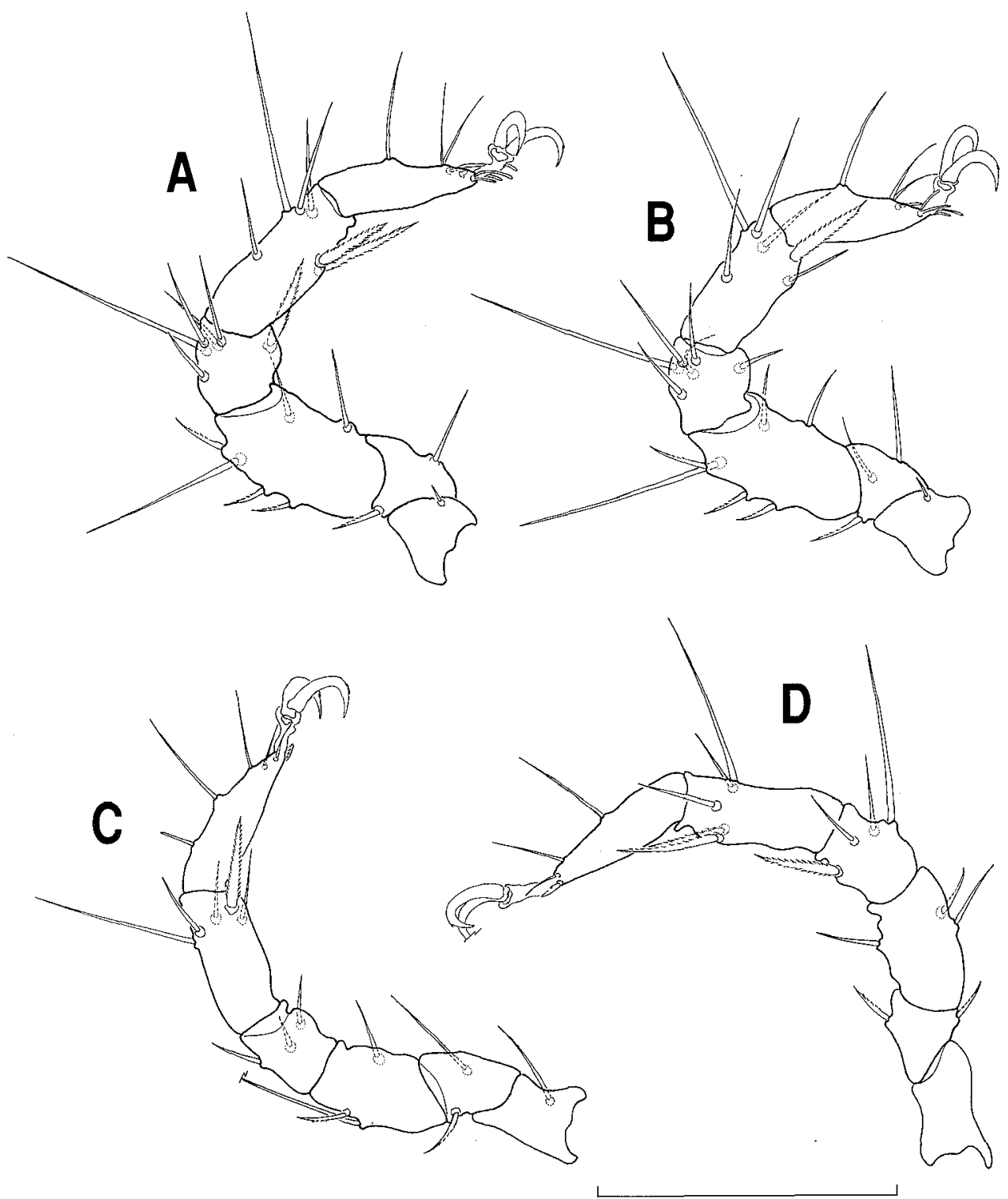

Fig. 48. Rhombognathus medialis sp. nov., female (holotype). A, leg I (L); B, leg II (L); C, leg III (R); D, leg IV (R). Scale bar $=100 \mu \mathrm{m}$.

anterolateral margin.

Venter (Fig. 46B) : Epimeral, and genital plates fused to form a single plate. Anal plate isolated at distal end of venter. Epimeral region entirely reticulated with faint panels, furnished with several subsurface pores medially, and with epimeral pore between insertions of leg I and leg II on each side. Lateral incisions with membranous cuticle very weak.

Chaetotaxy of epimeral region: Setae aes-i located at posteriorly to camerostome; aes-ii-lat placed medially at level posterior to insertion of leg II ; aes-ii-v placed medially; aes-ii-adj located on lateral margins, each consisting of two or three setae; pes-iii-lat placed 
dorsolaterally on posterior epimeral region; pes-iii-v near lateral margins; pes-iv-a placed most medially at level of insertion of leg III ; pes-iv-p located at level anterior to insertion of leg IV ; pes-iii-adj placed dorsolaterally, each consisting of one seta.

Genitoanal region (Fig. 46C) : Genital region surrounded posteriorly with striated membranous cuticle. Genital foramen completely separated from anal foramen by wide membranous area. Genital foramen $60 \mu \mathrm{m}$ long, $34 \mu \mathrm{m}$ wide, placed anteriorly at level slightly anterior to insertion of leg IV. Genital sclerites band-like, with three pairs of internal genital acetabula. Spermatheca indistinct.

Chaetotaxy of genitoanal region: Three pairs of filiform perigenital setae located at genitoanal region as arranged in Fig. 46C. Subgenital setae filiform; two pairs on genital sclerites, arranged 2-0. Adanal setae placed on anal papilla distidorsally.

Gnathosoma (Fig. 47A) : $90 \mu \mathrm{m}$ long, $70 \mu \mathrm{m}$ wide, gnathosoma-length/idiosoma-length 0 . 25. Base, length/width 0.85 . Rostrum $32 \mu \mathrm{m}$ long, nearly lanceolate, not reaching to level of distal end of palp. Rostral setae two pairs as follows : Proximal pair long and robust, at swollen point; distal pair short, at just anterior to proximal pair. Chelicera (Fig. 47B) with basal segment $74 \mu \mathrm{m}$ long, and movable digit $14 \mu \mathrm{m}$ long, bearing $12-13$ minute denticles along dorsal edge. Fixed digit extending distally to dorsal edge of movable digit. Palp (Fig. 47C) $42 \mu \mathrm{m}$ long ; P-1 short and cylindrical ; P-2 longest and robust, with a long filiform seta distidorsally; $\mathrm{P}-3$ short and cylindrical; $\mathrm{P}-4$ conical, with three short and thick filiform setae intermediately.

Legs (Figs. 48A-D) : Length of legs I, II, III, IV $=216,212,224,230 \mu \mathrm{m}$ respectively. Ornamentation indistinct. Lateral claw with very faint accessory tooth.

Leg chaetotaxy as follows: Trochanters I-IV, 1-1-1-0; basifemora I-IV, 2-3-2-2 ; telofemora I-IV, 6-6-3-3; genua I-IV, 6-6-3-4; tibiae I-IV, 6-6-5-5. As for large bipectinate setae: Genua I-IV, 1-0-0-1; tibiae I-IV, 2-1-1-2 (one seta is less pectinated). Tarsus I (Fig. 47D) with three dorsal setae, one solenidion, one famulus, and four parambulacral setae (paired doublet euphathidia). Solenidion long bacilliform on posterodorsal surface of claw fossa. Famulus papilliform with fine canaliculus at proximally to solenidion. Tarsus II (Fig. 47E) with three dorsal setae, one solenidion, and four parambulacral setae. Solenidion long bacilliform on posterodorsal surface of claw fossa. Tarsus III (Fig. 47F) with four dorsal setae and two parambulacral setae (one single euphathidium on posterior surface, one scaliform proeuphathidium on anterior surface). Tarsus IV (Fig. 47G) with three dorsal setae (one long filiform seta on basal claw fossa, one filiform seta on distal claw fossa, one fine filiform seta on anterodorsal surface) and two parambulacral setae (one filiform euphathidium on posterior surface, one scaliform proeuphathidium on anterior surface).

\section{Male (allotype)}

Idiosoma $316 \mu \mathrm{m}$ long, $216 \mu \mathrm{m}$ wide, gnathosoma-length/idiosoma-length 0.25 , resembling the female in essential respects except for character states of genitoanal region and chaetotaxy of tarsus IV.

Genitoanal region (Fig. 46D) incised laterally with membranous cuticle, furnished with a series of polygonal subsurface pores on each side of genital foramen, bearing branched 19 and 18 perigenital setae on each side of the foramen as arranged in Fig. 46D. Genital foramen 36 $\mu \mathrm{m}$ long, $12 \mu \mathrm{m}$ wide. Subgenital setae two pairs on genital sclerites, arranged 2-0. Genital acetabula three pairs. Spermatophorotype (cf. Fig. 46D) $58 \mu \mathrm{m}$ long, $50 \mu \mathrm{m}$ wide, massive and rhombic.

Tarsus IV (Fig. 47H) furnished with three dorsal setae (one long thick filiform seta on basal claw fossa, one filiform seta on distal claw fossa, one delicate filiform seta on anterodorsal surface of claw fossa) and two parambulacral setae (one scaliform proeuphathidium on anterior and posterior surface). 
Morphological variation and abnormality

The size range of the idiosoma, gnathosoma, and legs I-IV as follows.

Female $(\mathrm{n}=6)$. Idiosoma-length : 336-368 $\mu \mathrm{m}$, -width : 188-240 $\mu \mathrm{m}$; gnathosoma-length : 78-90 $\mu \mathrm{m}$, -width : $64-80 \mu \mathrm{m}$; leg-length : Leg I, 198-228 $\mu \mathrm{m}$; leg II, 202-222 $\mu \mathrm{m}$; leg III, 182 $-226 \mu \mathrm{m}$; leg IV, $210-240 \mu \mathrm{m}$.

Male $(\mathrm{n}=2)$. Idiosoma-length : 300-316 $\mu \mathrm{m}$, -width : 192-216 $\mu \mathrm{m}$; gnathosoma-length : 78-80 $\mu \mathrm{m}$, -width : 60-68 $\mu \mathrm{m}$; leg-length : Leg I, 206-208 $\mu \mathrm{m}$; leg II, 196-202 $\mu \mathrm{m}$; leg III, 184 $-206 \mu \mathrm{m}$; leg IV, 180-208 $\mu \mathrm{m}$.

The leg chaetotaxy varies among adult specimens $(\mathrm{n}=8)$ as follows: Trochanters I-IV, $(0,1) \cdots(0,1)-1-0$; basifemora I-IV, (1,2)-3-2-2 ; telofemora I-IV, $(4,6,7)-6-3-(3,4)$; genua I-IV, 6-(5,6)-3-4; tibiae I-IV , $6-(5,6)-5-5$. One of two bipectinate setae of tibia IV is less pectinated in some specimens. One specimen has only three dorsal setae on tarsus III.

The number of setae aes-ii-adj varies from two to three on each side of epimeral region. The number of the perigenital setae on each side of the genital foramen varies from 17 to 19 in the male.

\section{Remarks}

The outstanding character states of Rhombognathus medialis are the most medial location of the setae pes-iv-a, the terminal exsertion of the lateral sides of posterior dorsal plate, and the presence of a scaliform proeuphathidium on each anterior and posterior surface of tarsus IV in the male. In so far known Rhombognathus species, the position of the setae pes-iv-a is distinctly lateral than that of setae aes-ii-v. In $R$. medialis, however, the location of the setae pes-iv-a is approximately same as or more medial than that of aes-ii-v.

$R$. medialis bears general resemblance to $R$. leurodactylus $\mathrm{Krant} z, 1976, R$. lionyx Trouessart, 1899, and $R$. subtilis Bartsch, 1975. But $R$. medialis is easily distinguishable from these species by the above mentioned character states.

$R$. medialis has been found mainly from the coarse sandy sediment at intertidal zone. The present species would be a primarily arenicolous or epibenthic dweller.

The specific epithet is derived from the medial position of setae pes-iv-a.

Habitat-Intertidal zone: Algae - Sargassum thunbergii, Laminaria angustata, Cystoseira hakodatensis in tide pool. Coarse sandy sediment on tidal line to $0.3 \mathrm{~m}$ depth.

Distribution in Hokkaido-Oshoro, Daikoku Island, Sakaeura.

\section{Rhombognathus neotenus sp. nov.} [Japanese name: Osana-kaisoudani]

(Figs. 49-53)

Type series. Holotype: Female, among Mytilus edulis on tetrapod, intertidal, Date, Pacific coast of Hokkaido, 14.xii.1989, H. Abé coll. Allotype: Male, among Balanus cariosus on tetrapod, intertidal, Tomakomai, Pacific coast of Hokkaido, 27.iii.1989, H. Abé coll. Paratypes: 1 deutonymph, locality same as the allotype, 5.viii.1986, H. Abé coll.; 2 females and 2 males, locality same as the allotype, 24.ii.1989, H. Abé coll. ; 1 female, locality same as the allotype, 27. iii.1989, H. Abé coll. ; 1 deutonymph, locality same as the allotype, 10.iv.1989, H. Abé coll.; 3 females, Enteromorpha intestinalis on gravels at a depth of $0.1 \mathrm{~m}$, Shizunai, Pacific coast of Hokkaido, 22.v.1989, H. Abé coll.; 2 deutonymphs, locality same as the allotype, 22.v.1989, H. Abé coll.; 1 female, data same as the holotype; 1 female, Enteromorpha intestinalis on gravels at a tidal line, Shizunai, Pacific coast of Hokkaido, 20.iii.1992, H. Abé coll.

Female (holotype)

Idiosoma $328 \mu \mathrm{m}$ long, $204 \mu \mathrm{m}$ wide. Color in life dark green.

Dorsum (Fig. 49A) : Dorsal plate ornamented with clear panels (Fig. 49C) and partly with 
fine canaliculi. $\mathrm{AD}$ and PD separated by interval of less than PD-length. $\mathrm{AD} 104 \mu \mathrm{m}$ long, $100 \mu \mathrm{m}$ wide, strongly protruded anteriorly and truncated posteriorly, furnished with a dorsal pore near each lateral margin, without distinct areolation. OC $90 \mu \mathrm{m}$ long, extending posteriorly to level of the insertion of leg III, furnished with two large corneae and two large polygonal pores, bearing one pore-like angular structure near lateral margin, one maze-like subsurface pore medially to anterior cornea. Areolation not clear. PD $162 \mu \mathrm{m}$ long, $114 \mu \mathrm{m}$ wide, convex anteriorly, furnished with small subsurface pore on lateral margin, and with dorsal pore on posterolateral margin on each side. Costae absent.

Chaetotaxy of dorsal region: Setae ds-i on $\mathrm{AD}$, longer and thicker than the others; $d s-i i$ each on OC near anterior margin; ds-iii each on OC near medial margin; ds-iv placed on anterolateral margin of $\mathrm{PD}$; and $\mathrm{ds}-\mathrm{v}$ at mid level on PD.

Venter (Fig. 49B) : Membranous cuticle clearly striated. Ventral plates each separated and entirely ornamented with porous panels. AE $82 \mu \mathrm{m}$ long, $204 \mu \mathrm{m}$ wide, concave posteriorly, reaching posteriorly to level about midway between insertions of leg II and leg III, furnished with a number of subsurface pores medially as well as along posterior margin, and with epimeral pore between insertions of leg I and leg II on each side. A pair of round subsurface pores located on striated membranous cuticle posteriorly to AE. PE $122 \mu \mathrm{m}$ long, ornamented with several subsurface pores along anterolateral margin. Genital plate $84 \mu \mathrm{m}$ long, $86 \mu \mathrm{m}$ wide, subtriangular in shape, reaching anteriorly to level posterior to the insertion of leg III. Anal plate $90 \mu \mathrm{m}$ wide, separated from genital plate by a strip of striated membranous cuticle.

Chaetotaxy of epimeral region: Setae aes-i on AE, at level of the insertion of leg II; aes-ii-lat on $\mathrm{AE}$, near posterolateral margins ; aes-ii-v on $\mathrm{AE}$, near posterior margin ; aes-iiadj located near lateral margins, each consisting of two setae; pes-iii-lat located dorsally on $\mathrm{PE}$; pes-iii-v at lateral margins of PE; pes-iii-adj placed dorsally on PE, each consisting of one thick seta ; pes-iv-a on PE, at level of insertion of leg III ; pes-iv-p placed at level anterior to insertion of leg IV.

Genitoanal region (Fig. 50A): A round subsurface pore placed near each anterolateral margin of genital plate. Genital foramen $70 \mu \mathrm{m}$ long, $40 \mu \mathrm{m}$ wide, elliptical, located posteromedially on genital plate. Genital sclerites band-like, extending posteriorly somewhat beyond posterior margin of genital plate. Genital acetabula internal, only two pairs visible. Spermatheca not seen.

Chaetotaxy of genitoanal region: Two pairs of long filiform perigenital setae located on genital plate as arranged in Fig. 50A. Subgenital setae short filiform; two pairs on genital sclerites, arranged 2-0. Adanal setae placed distidorsally on anal papilla.

Gnathosoma (Fig. 49D) : $80 \mu \mathrm{m}$ long, $70 \mu \mathrm{m}$ wide, gnathosoma-length/idiosoma-length 0 . 24. Base, length/width 0.73 , slightly expanded laterally, ornamented with several panels. Rostrum approximately $30 \mu \mathrm{m}$ long, Rostral setae two pairs as follows : Proximal pair long and robuist, at half level of rostrum; distal pair at just anterior to proximal pair. Chelicera (Fig. 49E) with basal segment $76 \mu \mathrm{m}$ long, and movable digit $18 \mu \mathrm{m}$ long, bearing 11-12 minute denticles along dorsal edge. Fixed digit extending distally to about midway of movable digit. Palp (Fig. 49F) $48 \mu \mathrm{m}$ long; P-1 short and cylindrical; P-2 longest and robust, weakly reticulated, with a filiform seta distidorsally; $\mathrm{P}-3$ short and cylindrical ; P-4 conical, with three short and thick filiform setae intermediately, and with two appressed blunt spiniform projections terminally.

Legs (Figs. 51A-D) : Length of legs I, II, III, IV $=222,228,234,236 \mu \mathrm{m}$ respectively, ornamented with fine porous panels which are clear on telofemora. Lateral claw with tiny dentations along inner edge and faint accessory tooth. Short setae usually faintly rough; long seta smooth.

Leg chaetotaxy as follows: Trochanters I-IV : 1-1-1-0; basifemora I-IV, 2-3-2-2; 


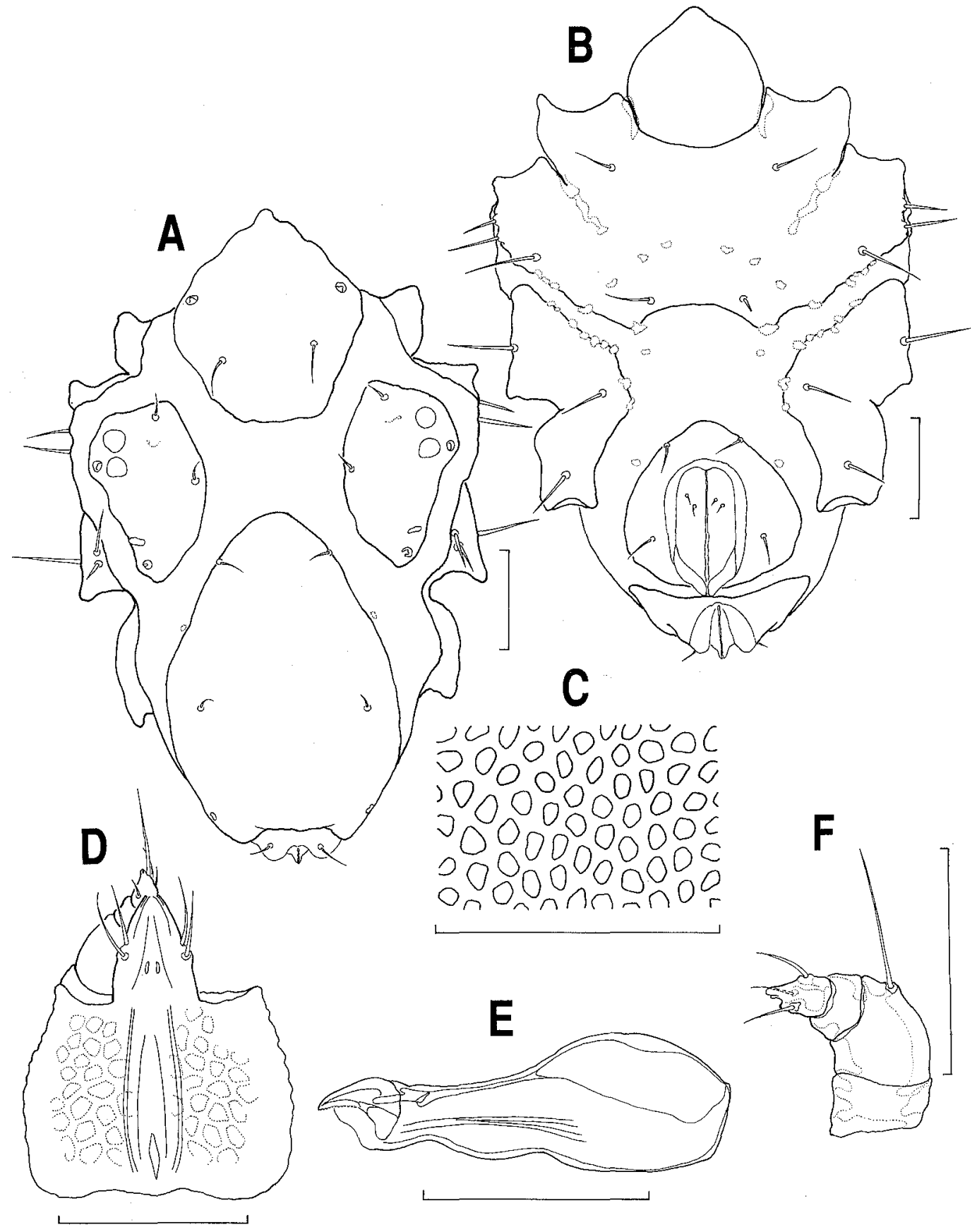

Fig. 49. Rhombognathus neotenus sp. nov., female (holotype). A, idiosoma (Ds) ; B, idiosoma (Vr) ; C, panels on PD ; D, gnathosoma (Vr) (left palp omitted) ; E, chelicera (L) ; F, palp (L). Scale bars $=50$ $\mu \mathrm{m}$. 


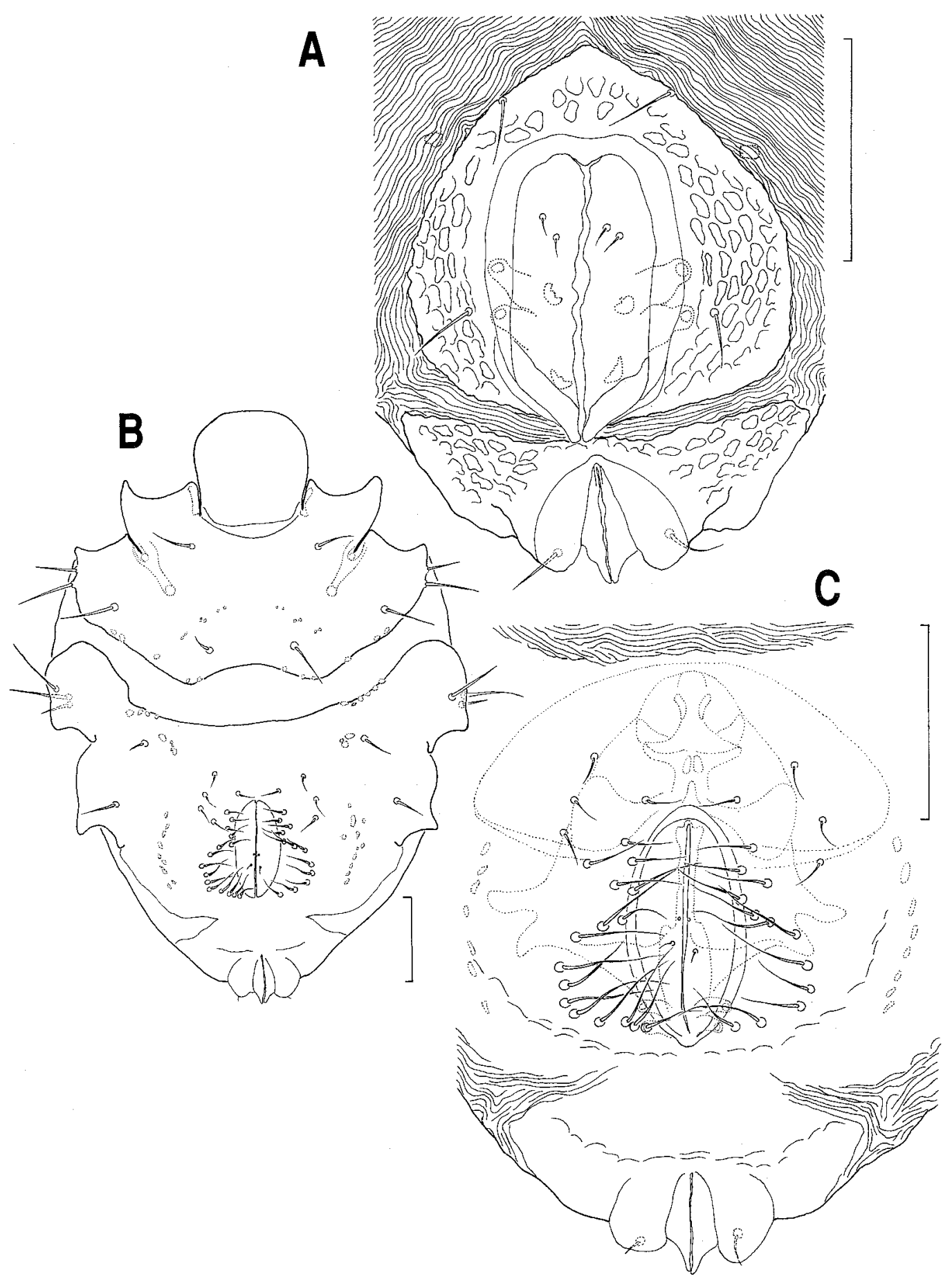

Fig. 50. Rhombognathus neotenus sp. nov., female (holotype). A, genitoanal region. Male (allotype). $\mathrm{B}$, idiosoma (Vr); C, genitoanal region. Scale bars $=50 \mu \mathrm{m}$. 


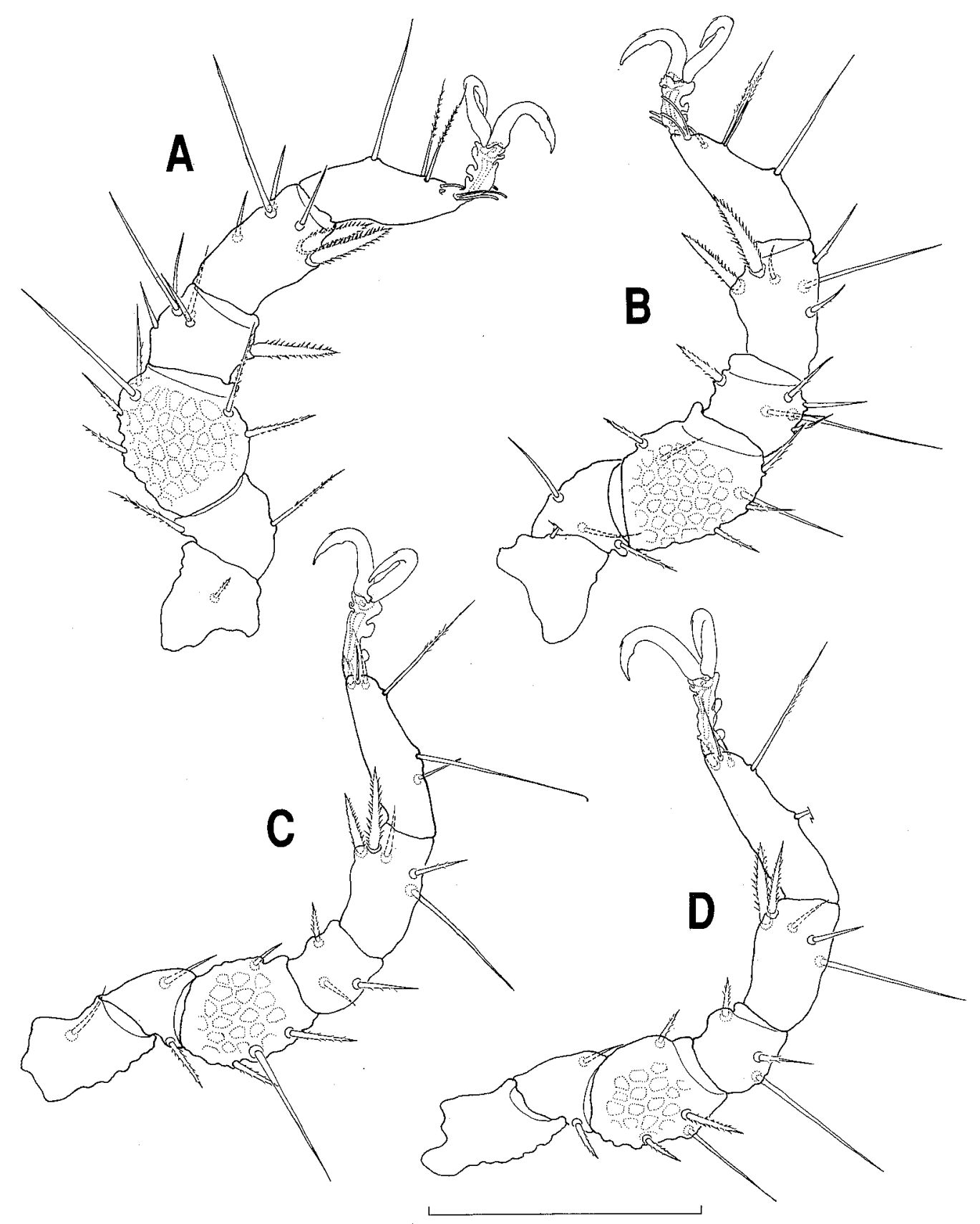

Fig. 51. Rhombognathus neotenus sp. nov., female (holotype). A, leg I (R) ; B, leg II (R); C, leg III (L) ; D, leg IV (L). Male (allotype). E, leg IV (L). Scale bar $=100 \mu \mathrm{m}$.

telofemora I-IV, 6-6-4-4; genua I-IV, 6-6-3-3; tibiae I-IV, 6-6-5-5. As for large bipectinate setae: Genua I-IV : 1-0-0-0; tibiae I-IV, 2-2-2-2; genu II also with a bipectinate seta, but short and less pectinated. Tarsus I (Fig. 52A) with three dorsal setae, one solenidion, one famulus, and four parambulacral setae (paired doublet euphathidia). 


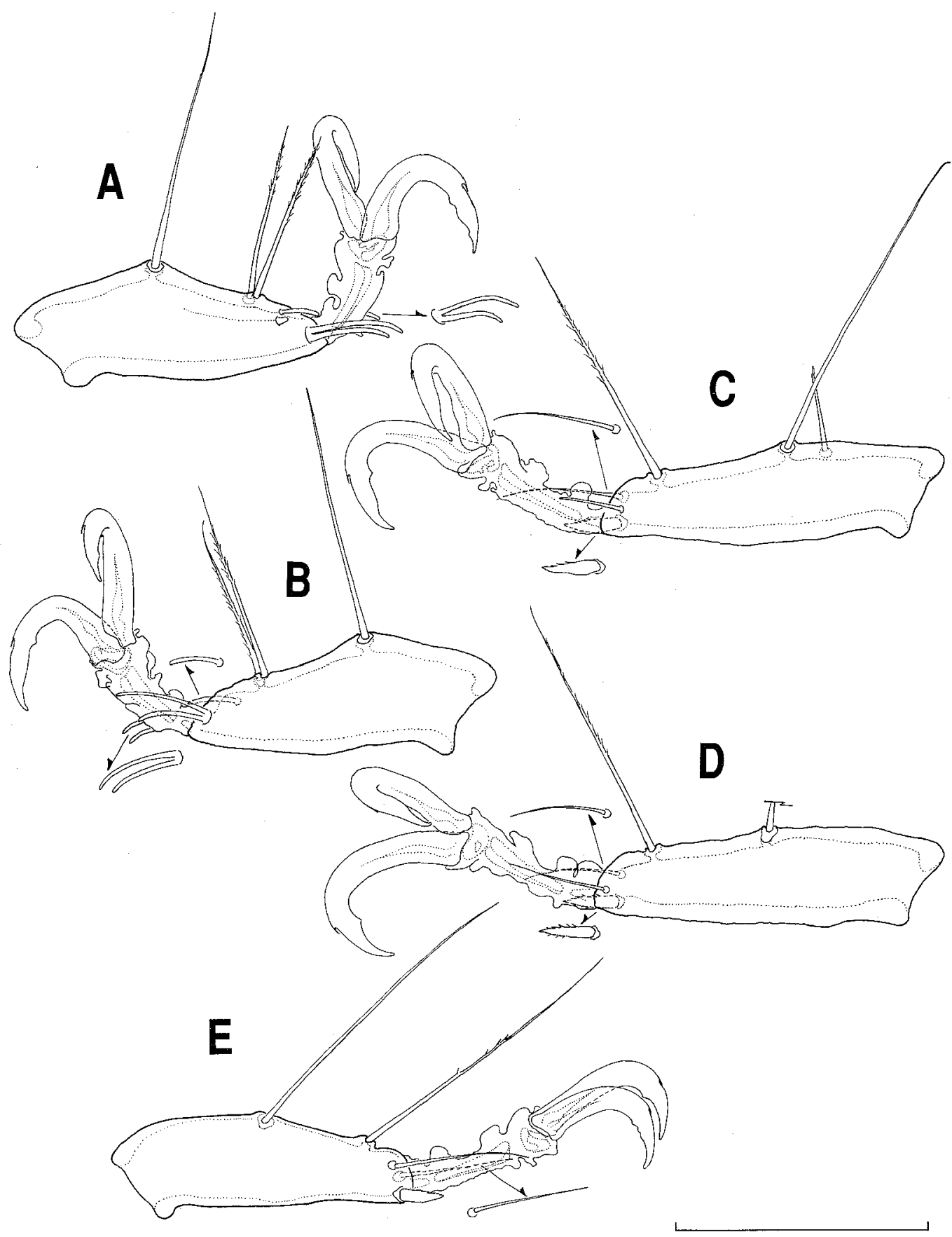

Fig. 52. Rhombognathus neotenus sp. nov., female (holotype). A, tarsus I (R); B, tarsus II (R); C, tarsus III (L) ; D, tarsus IV (L). Male (allotype). E, tarsus IV (L). Scale bar $=50 \mu \mathrm{m}$. 
Solenidion long straight bacilliform on posterodorsal surface of claw fossa. Famulus papilliform with fine canaliculus at just ventrally to solenidion. Tarsus II (Fig. 52B) with three dorsal setae, one solenidion, and four parambulacral setae. Solenidion long bacilliform on posterodorsal surface of claw fossa. Tarsus III (Fig. 52C) with four dorsal setae and two parambulacral setae (one single filiform euphathidium on posterior surface, one scaliform proeuphathidium on anterior surface). Tarsus IV (Fig. 52D) with three dorsal setae (one long thick filiform seta on basal claw fossa, one faintly plumose seta on distal claw fossa, one fine filiform seta on anterodorsal surface) and two parambulacral setae (one fine filiform euphathidium on posterior surface, one scaliform proeuphathidium on anterior surface).

Male (allotype)

Idiosoma $340 \mu \mathrm{m}$ long, $220 \mu \mathrm{m}$ wide, gnathosoma-length/idiosoma-length 0.22 resembling the female in essential respects except for character states of epimeral plates and genitoanal region.

Venter (Fig. 50B) : Posterior epimeral plates and genital plate completely fused to a single plate from which anal plate partly separated by lateral incisions with membranous cuticle.

Genitoanal region (Fig. 50C) furnished with a series of polygonal subsurface panels, and with 16 and 20 filiform perigenital setae on each side of genital foramen as arranged in Fig. 50C. Genital foramen $58 \mu \mathrm{m}$ long, $30 \mu \mathrm{m}$ wide. Only one pair of subgenital setae discernible at mid level on genital sclerite, but normally two pairs. Genital acetabula only two pairs. Spermatophorotype (cf. Fig. 50C) $90 \mu \mathrm{m}$ long, $90 \mu \mathrm{m}$ wide, very massive. Adanal setae one pair placed on anal papilla dorsally.

Tarsus IV (Fig. 52E) similar to that in the female.

Tritonymph (paratype)

Idiosoma $380 \mu \mathrm{m}$ long, $240 \mu \mathrm{m}$ wide, gnathosoma-length/idiosoma-length 0.21 .

Dorsum: Dorsal plate ornamented with clear panels, and well developed as same as those of adults. AD $106 \mu \mathrm{m}$ long, $104 \mu \mathrm{m}$ wide, protruded anteriorly. OC $112 \mu \mathrm{m}$ long. PD $190 \mu \mathrm{m}$ long, $160 \mu \mathrm{m}$ wide, strongly protruded anteriorly. AD and PD separated by interval about $\mathrm{AD}$-length.

Venter: Epimeral plates separated and ornamented with clear panels. AE $88 \mu \mathrm{m}$ long, $214 \mu \mathrm{m}$ wide, furnished with one aes-ii-adj on each lateral margin. PE $120 \mu \mathrm{m}$ long, without pes-iii-adj.

Genitoanal region (Fig. 53A): Genital plate and anal plate completely fused into genitoanal plate, $120 \mu \mathrm{m}$ long, $104 \mu \mathrm{m}$ wide, obovoid in shape, furnished with two pairs of perigenital and one pair of subgenital setae, bearing a tiny subsurface pore on each lateral margin. Primordial genital slit with only two pairs of internal genital acetabula.

Legs: Length of legs I, II, III, IV $=220,216,226,226 \mu \mathrm{m}$ respectively. Leg chaetotaxy of trochanters I-IV , 0-1-1-0; basifemora I-IV, 2-3-2-1; telofemora I-IV, 5-5-4-2 ; genua I-IV, 5-5-3-3 ; tibiae I-IV , 5-5-5-5. Distinct bipectinate setae on genua I-IV : $1-0-0-0$, tibiae I-IV : $2-2-2-2$.

Morphological variation and abnormality

The oviferous female specimens have large body size. Metric character states are given below.

Dorsum (Fig. 53B) : AD and PD separated by interval of approximately three times as long as AD-length. AD $98 \mu \mathrm{m}$ long, $100 \mu \mathrm{m}$ wide, protruded anteriorly, reaching posteriorly to level of insertion of leg II, OC $90 \mu \mathrm{m}$ long, separated from AD by about AD-length. PD $138 \mu \mathrm{m}$ long, $122 \mu \mathrm{m}$ wide, protruded anteriorly, separated from OC by about PD-length.

Venter (Fig. 53C) : AE $76 \mu \mathrm{m}$ long, $234 \mu \mathrm{m}$ wide, convex posteriorly. PE $124 \mu \mathrm{m}$ long. 


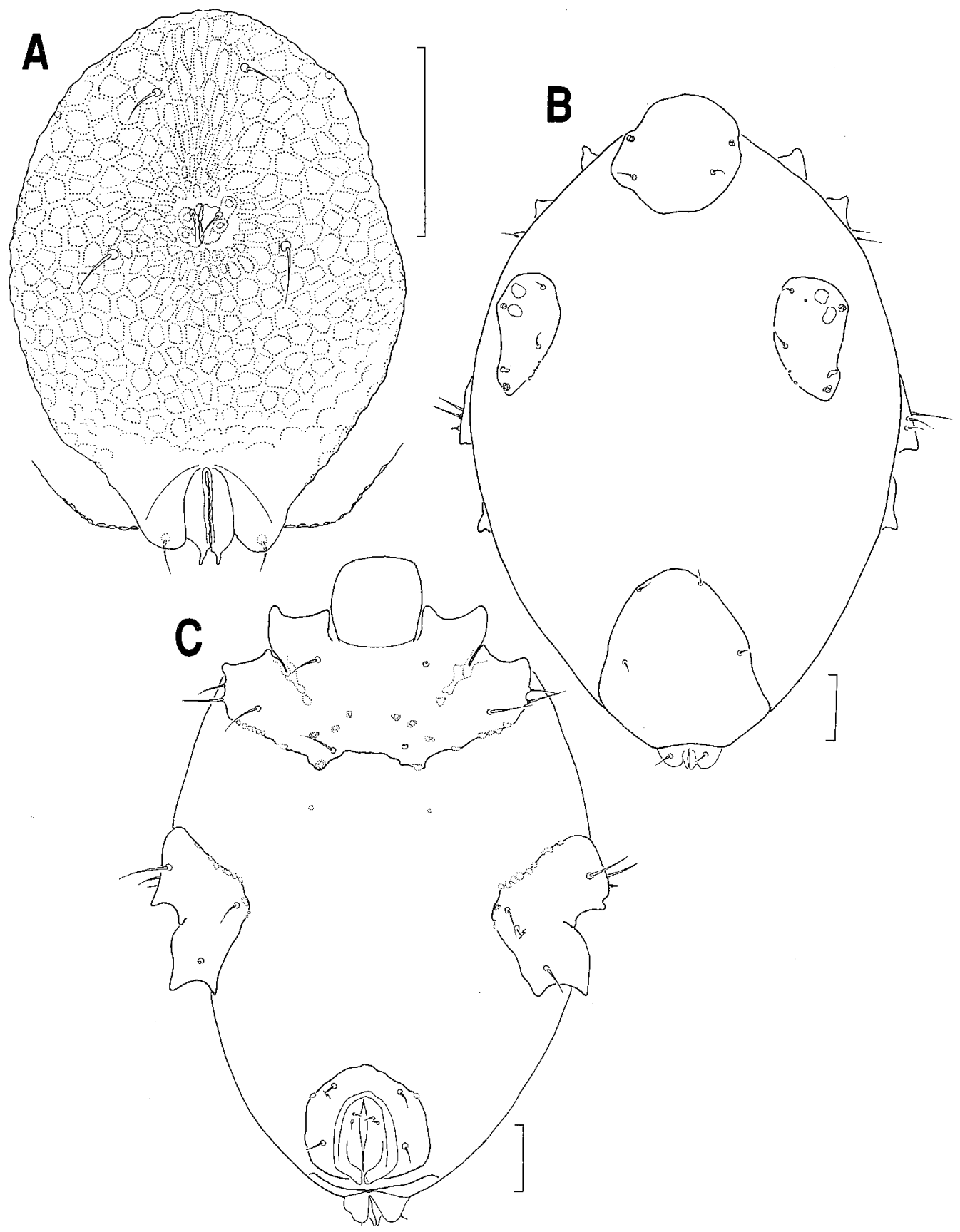

Fig. 53. Rhombognathus neotenus sp. nov., tritonymph (paratype). A, genitoanal region. Female (paratype). B, idiosoma (Ds) ; C, idiosoma (Vr). Scale bars $=50 \mu \mathrm{m}$. 
Genital plate $92 \mu \mathrm{m}$ long, $98 \mu \mathrm{m}$ wide, separated from $\mathrm{AE}$ about three times as long as a length of the genital plate. Anal plate $104 \mu \mathrm{m}$ wide.

Legs: Length of legs I, II, III, IV $=240,242,256,256 \mu \mathrm{m}$ respectively.

The size range of the idiosoma, gnathosoma, and legs I-IV as follows.

Female (oviferous, $\mathrm{n}=4$ ). Idiosoma-length : $504-564 \mu \mathrm{m}$, -width : $280-380 \mu \mathrm{m}$; gnathosoma-length : $76-88 \mu \mathrm{m}$, -width : $68-80 \mu \mathrm{m}$; leg-length : Leg I, $222-250 \mu \mathrm{m}$; leg II, 220 $-246 \mu \mathrm{m}$; leg III, $228-276 \mu \mathrm{m}$; leg IV, $232-268 \mu \mathrm{m}$.

Female (unoviferous, $\mathrm{n}=4$ ). Idiosoma-length: 304-420 $\mu \mathrm{m}$, -width: 192-272 $\mu \mathrm{m}$; gnathosoma-length : $76-92 \mu \mathrm{m}$, -width : $64-84 \mu \mathrm{m}$; leg-length : Leg I, 192-266 $\mu \mathrm{m}$; leg II, 200 $-254 \mu \mathrm{m}$; leg III, $200-270 \mu \mathrm{m}$; leg IV, $210-252 \mu \mathrm{m}$.

Male $(\mathrm{n}=3)$. Idiosoma-length : $340-348 \mu \mathrm{m}$, -width : $216-228 \mu \mathrm{m}$; gnathosoma-length : 68-76 $\mu \mathrm{m}$, -width : 60-66 $\mu \mathrm{m}$; leg-length : Leg I, 194-200 $\mu \mathrm{m}$; leg II, $182-200 \mu \mathrm{m}$; leg III, 194 $-208 \mu \mathrm{m}$; leg IV, 192-204 $\mu \mathrm{m}$.

Tritonymph $(\mathrm{n}=4)$. Idiosoma-length : $352-380 \mu \mathrm{m}$, -width : $240-268 \mu \mathrm{m}$; gnathosomalength : 70-80 $\mu \mathrm{m}$, -width : 72-76 $\mu \mathrm{m}$; leg-length : Leg I, 194-220 $\mu \mathrm{m}$; leg II, $196-216 \mu \mathrm{m}$; leg III, 198-226 $\mu \mathrm{m}$; leg IV, 202-226 $\mu \mathrm{m}$.

The leg chaetotaxy varies as follows.

Adult $(\mathrm{n}=11)$ : Trochanters I-IV, 1-1-1-0 ; basifemora I-IV, 2-(2,3)-2-2 ; telofemora IIV, $(5,6,7)-(5,6)-(3,4,5)-4$; genua I-IV, $(4,5,6)-6-3-3$; tibiae I-IV, $(5,6)-(5,6)-(5,6)-5$. As for large bipectinate setae varies as follows: Tibiae I-IV:2-2-(1,2)-(0,1,2).

Tritonymph $(\mathrm{n}=4)$ : Trochanters I-IV, $(0,1)-1-1-0$; basifemora I-IV, 2-3-2-1; telofemora I-IV , 5-5-(3,4)-2 ; genua I-IV , 5-5-3-3; tibiae I-IV , 5-5-5-5. Bipectinate setae on tibiae III and IV are short and less pectinated.

The number of the perigenital setae on each side of the genital foramen varies from one to three in the female, 14 to 20 in the male. The number of setae aes-ii-adj on each side of anterior epimeral plate varies from two to three. One female specimen has two pes-iii-adj on each posterior epimeral plate. One tritonymph specimen has one pes-iii-adj.

\section{Remarks}

Rhombognathus neotenus is easily recognized on the basis of the condition of ventral plates (all plates are separated in the female, posterior epimeral, genital and anal plates are fused in the male), two pairs of perigenital setae in the female, filiform perigenital setae in the male, only two pairs of genital acetabula in adults, and tibiae I-IV with 2-2-2-2 large bipectinate setae.

$R$. neotenus closely resembles $R$. gressitti Newell, 1967, and $R$. dictyotus Bartsch, 1992 in the conformation of the ventral plates in adults. However, $R$. neotenus differs from the latter two species in having only two perigenital setae in the female, and two pairs of genital acetabula in adults.

The adult of $R$. neotenus well retains some nymphal conditions as follows: 1) ventral plate is completely separated in the female, 2) merely two perigenital setae exist on the genital plate in the female, 3) only two pairs of genital acetabula are present.

The oviferous female specimens are approximately 1.5 times as large as unoviferous ones. The membranous cuticle has a remarkable elasticity, and the adult body size abruptly increases with the germinal development. Taking such a growth mode into consideration, a caution must be paid when one treats body size as a significant taxonomic character.

Rhombognathus species generally have three pairs of genital acetabula in adults. $R$. neotenus is characterized by having two pairs of large genital acetabula which are typically seen in some Isobactrus species inhabiting low salinity water, e.g., I. calderensis, I. hartmanni, I. hutchinsoni, I. macquariensis, and I. uniscutatus. R. neotenus is usually found in brackish water in an estuarine area. The function of genital acetabula is known to participate in 
osmotic regulation (Bartsch, 1973; Alberti \& Storch, 1977; Alberti, 1979; Fashing, 1988; Evans, 1992). Therefore, the reduction of genital acetabula may relate to the low salinity environment.

The specific epithet is derived from the neotenic character states observed in the present species.

Habitat-Intertidal zone: Algae - Enteromorpha intestinalis on gravels, Neorhodomela aculeata, Fucus evanescens in tide pool. Mussels - Mytilus edulis on tetrapod. Barnacles Balanus cariosus on tetrapod. Coarse sandy sediment.

Distribution in Hokkaido-Date, Tomakomai, Shizunai, Utoro.

\section{Rhombognathus sinensis Bartsch, 1990}

[Japanese name: Shina-kaisoudani]

(Figs. 54-57)

Rhombognathus sinensis Bartsch, 1990, 663-664, fig. 2; Bartsch, 1992, 257-258, fig. 3.

Specimens examined. One female, on Gymnogongrus flabelliformis at a depth of $0.1 \mathrm{~m}$ in tide pool, intertidal, Oshoro (Nekodomari), Japan Sea coast of Hokkaido, 30.viii.1988, H. Abé coll.; 2 females and 2 males, among Mytilus edulis on ledge, intertidal, Oshoro (Nekodomari), Japan Sea coast of Hokkaido, 13.ii.1989, H. Abé coll.

Female

Idiosoma $324 \mu \mathrm{m}$ long, $200 \mu \mathrm{m}$ wide. Color in life dark green.

Dorsum (Fig. 54A) : Dorsal plate uniformly ornamented with clear panels (Fig. 54F), and partly with fine canaliculi. $\mathrm{AD}$ and $\mathrm{PD}$ separated by interval of approximately a half of $\mathrm{AD}$ -length. AD $116 \mu \mathrm{m}$ long, $114 \mu \mathrm{m}$ wide, strongly protruded posteriorly, ornamented with weak areolation posteriorly, with a dorsal pore near each lateral margin. OC $49 \mu \mathrm{m}$ long, extending anteriorly to level of the insertion of leg II, reaching pasteriorly at level of insertion of leg III, furnished with two small corneae and two polygonal pores, bearing one tiny pore-like structure on lateral margin, one maze-like subsurface pore medially to corneae, and two tiny subsurface pores near each posteromedial margin. Areolation indistinct. PD $156 \mu \mathrm{m}$ long, $114 \mu \mathrm{m}$ wide, furnished with a small subsurface pore on anterolateral margin, and with dorsal pore on posterior margin on each side. Costae inconspicuous.

Chaetotaxy of dorsal region: Dorsal setae short. Setae ds-i on AD; ds-ii and ds-iii each on OC; ds-iv on PD, near anterolateral margin. Setae ds-v absent.

Venter (Fig. 54B) : Epimeral and genitoanal plates fused to form a single plate. Ventral plates are entirely reticulated with weak porous panels. Epimeral region furnished with several subsurface pores medially, and with epimeral pore between insertions of leg I and leg II on each side, without clear lateral incisions.

Chaetotaxy of epimeral region: Setae aes-i located posteriorly to camerostome ; aes-iilat placed near lateral margin; aes-ii-v placed most medially; aes-ii-adj located on dorsolateral margins, each consisting of one seta ; pes-iii-lat placed dorsally on posterior epimeral region ; pes-iii-v near lateral margins ; pes-iv-a placed medially at level of slightly anterior to insertion of leg III ; pes-iv-p located at level anterior to insertion of leg IV ; pes-iii-adj located dorsolaterally, each consisting of one seta.

Genitoanal region (Fig. 55A): Genitoanal region without distinct lateral incisions. Genital foramen $76 \mu \mathrm{m}$ long, $44 \mu \mathrm{m}$ wide, occupying from level slightly posterior to insertion of leg IV to level anterior to anal foramen. Genital sclerites band-like, with three pairs of internal genital acetabula. Spermatheca indistinct.

Chaetotaxy of genitoanal region: Five pairs of filiform perigenital setae located at each 


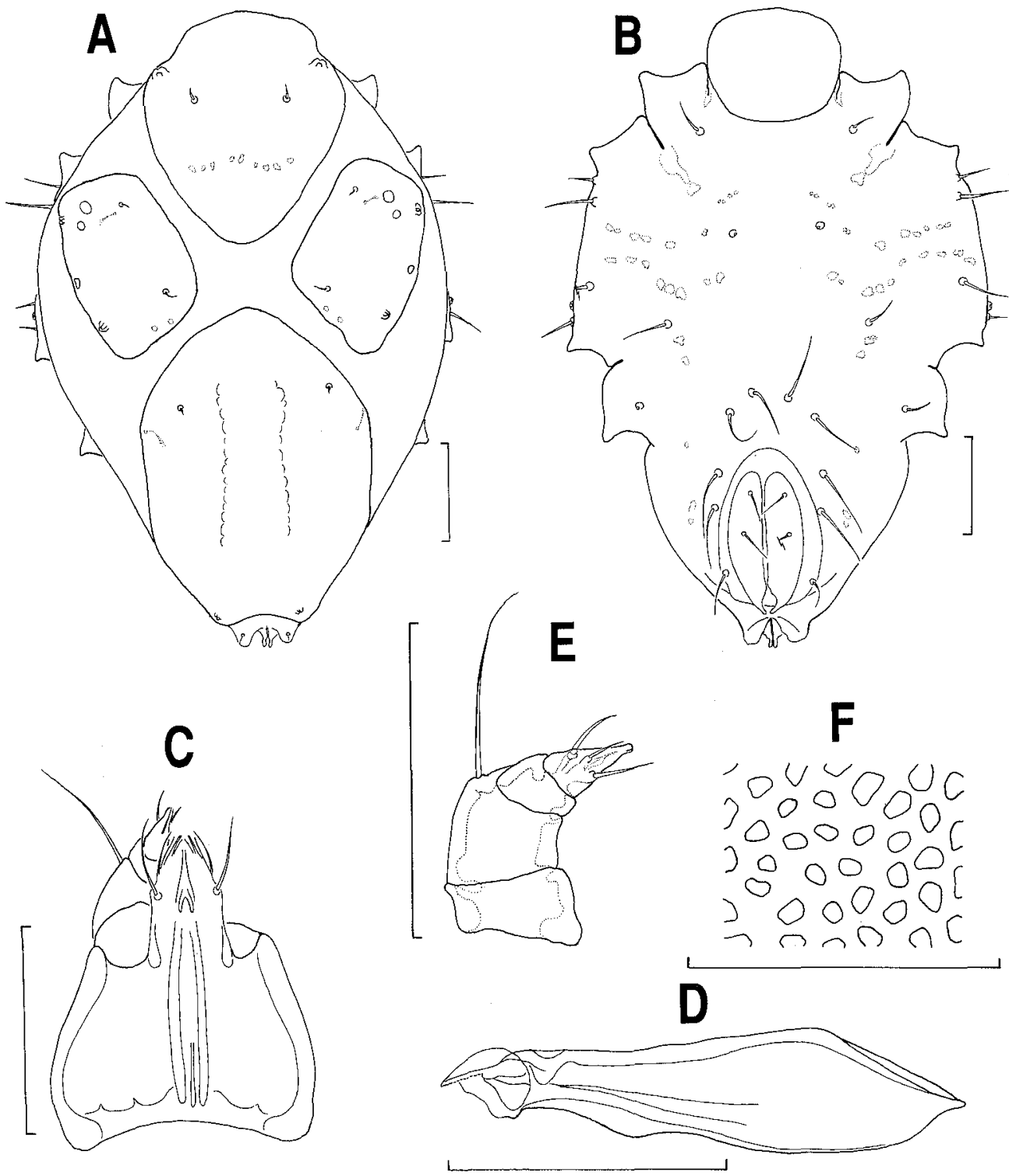

Fig. 54. Rhombognathus sinensis Bartsch, 1990, female. A, idiosoma (Ds); B, idiosoma (Vr); C, gnathosoma (Vr) (left palp omitted) ; D, chelicera (L); E, palp (L) ; F, panels on PD. Scale bars $=50$ $\mu \mathrm{m}$.

side of genital foramen as arranged in Fig. 55A. Subgenital setae filiform; two pairs on genital sclerites, arranged 2-0. Adanal setae very fine, placed dorsally on anal papilla.

Gnathosoma (Fig. 54C) : $74 \mu \mathrm{m}$ long, $64 \mu \mathrm{m}$ wide, gnathosoma-length/idiosoma-length 0 . 23. Base, length/width 0.60 . Rostrum $32 \mu \mathrm{m}$ long, nearly lanceolate, not reaching to level of distal end of palp. Rostral setae two pairs as follows: Proximal pair long and robust, at swollen point; distal pair short, at just anterior to proximal pair. Chelicera (Fig. 54D) with basal segment $72 \mu \mathrm{m}$ long, and movable digit $16 \mu \mathrm{m}$ long, bearing 10-12 denticles along dorsal 


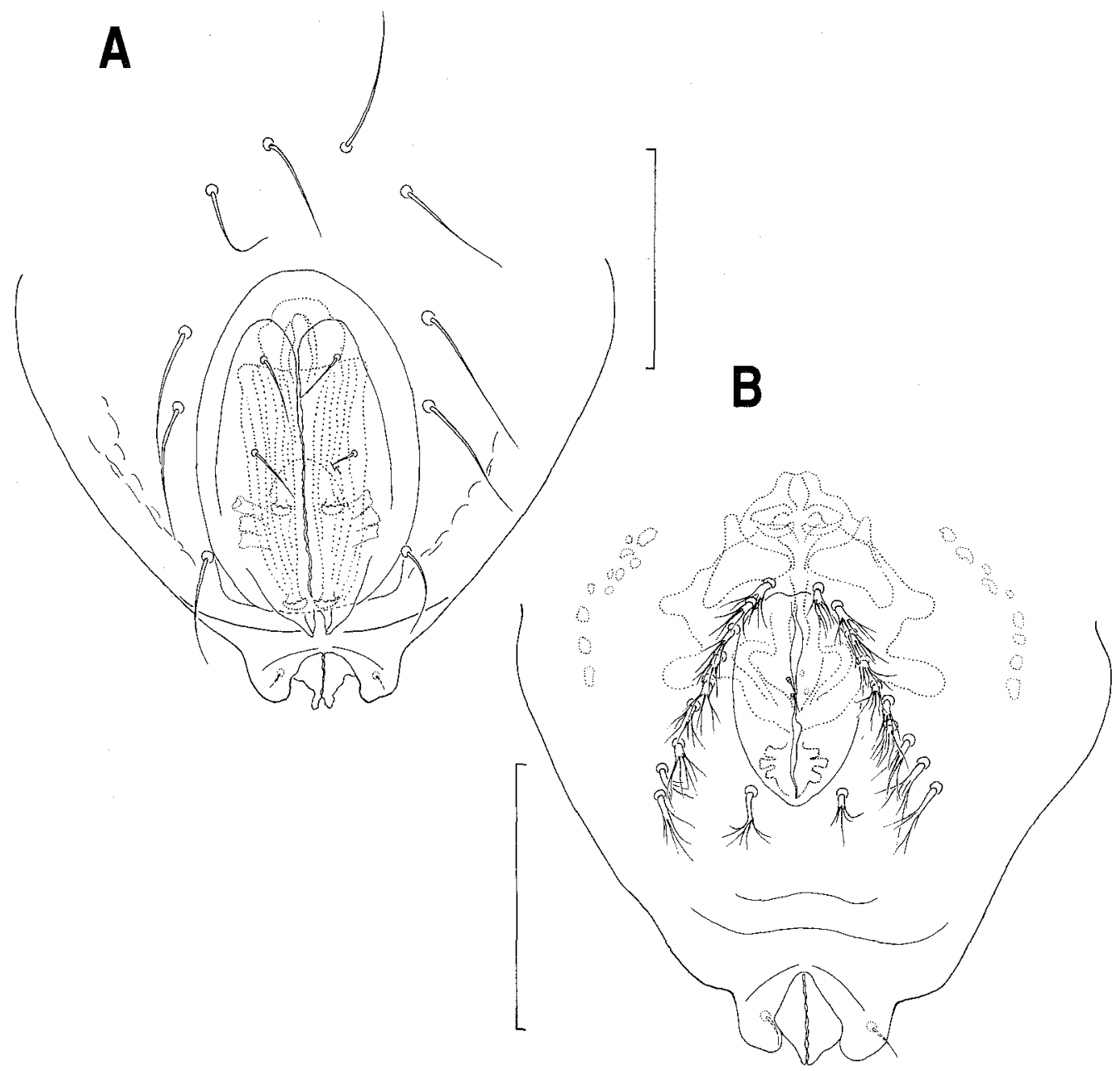

Fig. 55. Rhombognathus sinensis Bartsch, 1990, genitoanal region. A, female; B, male. Scale bars= $50 \mu \mathrm{m}$.

edge. Fixed digit extending distally to mid level of movable digit. Palp (Fig. 54E) $40 \mu \mathrm{m}$ long; P-1 short and cylindrical; P-2 longest, with a long filiform seta distidorsally ; $\mathrm{P}-3$ short and cylindrical ; P-4 conical, with two filiform and one blade-like setae intermediately.

Legs (Figs. 56A-D) : Length of legs I, II, III, IV $=202,184,194,192 \mu \mathrm{m}$ respectively. Ornamentation indistinct. Lateral claw with palmate accessory process, bearing 6 to 10 delicate teeth.

Leg chaetotaxy as follows: Trochanters I-IV, 1-1-1-0; basifemora I-IV, 2-2-2-2 ; telofemora I-IV, 6-7-4-4; genua I-IV, 5-5-3-3; tibiae I-IV, 5-5-5-5. As for large bipectinate setae: Genua I-IV, $0-0-0-0$; tibiae I-IV, 2-1-1-2 (one seta is less pectinated). Tarsus I (Fig. 57A) with three dorsal setae, one solenidion, one famulus, and four parambulacral setae (paired doublet euphathidia). Solenidion long bacilliform on posterodorsal surface of claw fossa. Famulus papilliform with fine canaliculus at just proximally to solenidion. Tarsus II (Fig. 57B) with three dorsal setae, one solenidion, and four parambulacral setae. 

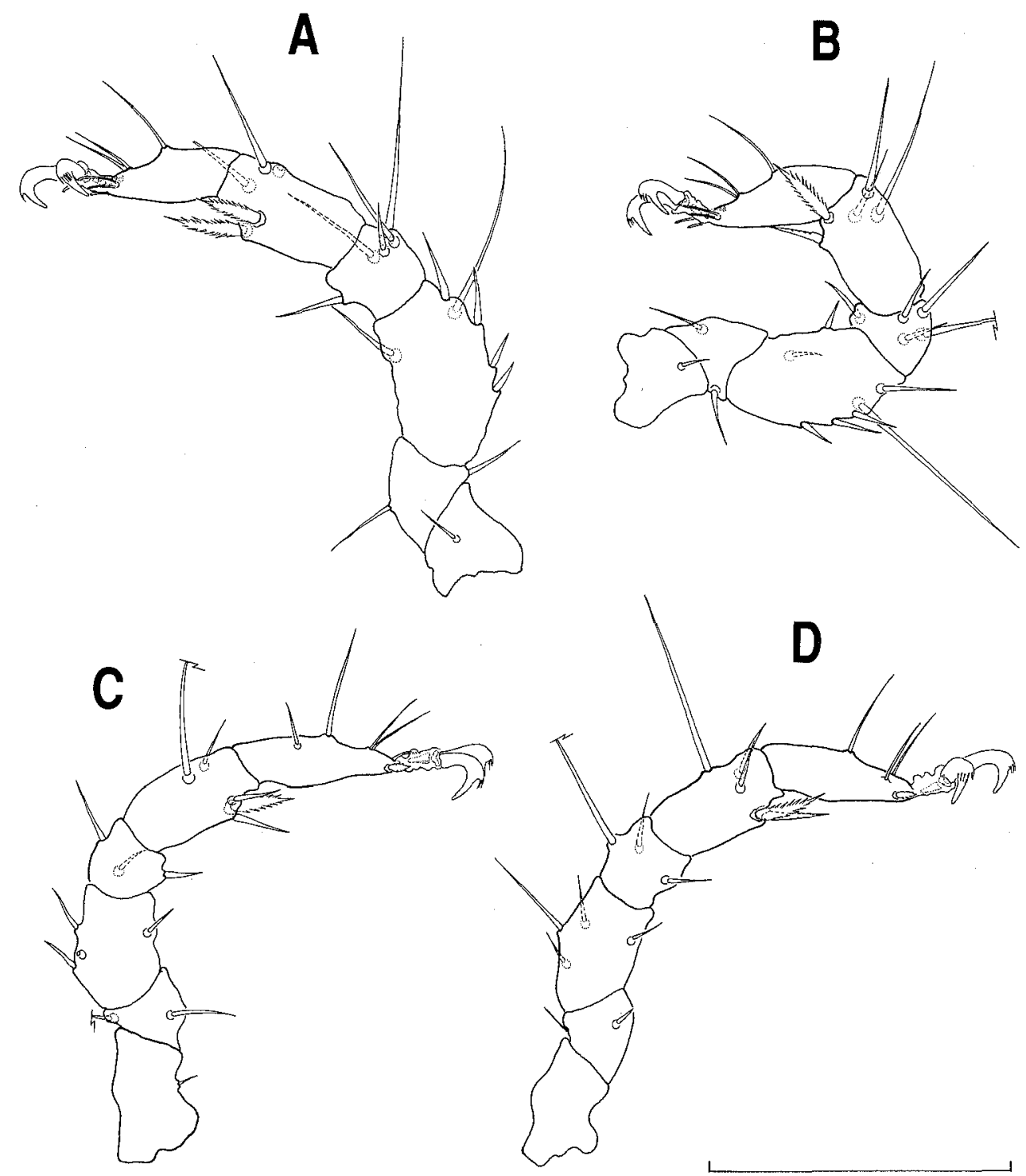

Fig. 56. Rhombognathus sinensis Bartsch, 1990, female. A, leg I (R); B, leg II (R) ; C, leg III (L); D, leg IV (L). Scale bar $=100 \mu \mathrm{m}$.

Solenidion long bacilliform on posterodorsal surface of claw fossa. Tarsus III (Fig. 57C) with four dorsal setae and two parambulacral setae (one single euphathidium on posterior surface, one scaliform proeuphathidium on anterior surface). Tarsus IV (Fig. 57D) with three dorsal setae (one long faintly plumose seta on basal claw fossa, two weakly plumose seta on distal claw fossa) and two parambulacral setae (one fine filiform euphathidium on posterior surface, one scaliform proeuphathidium on anterior surface).

Male

Idiosoma $280 \mu \mathrm{m}$ long, $168 \mu \mathrm{m}$ wide, gnathosoma-length/idiosoma-length 0.26 , resembling 

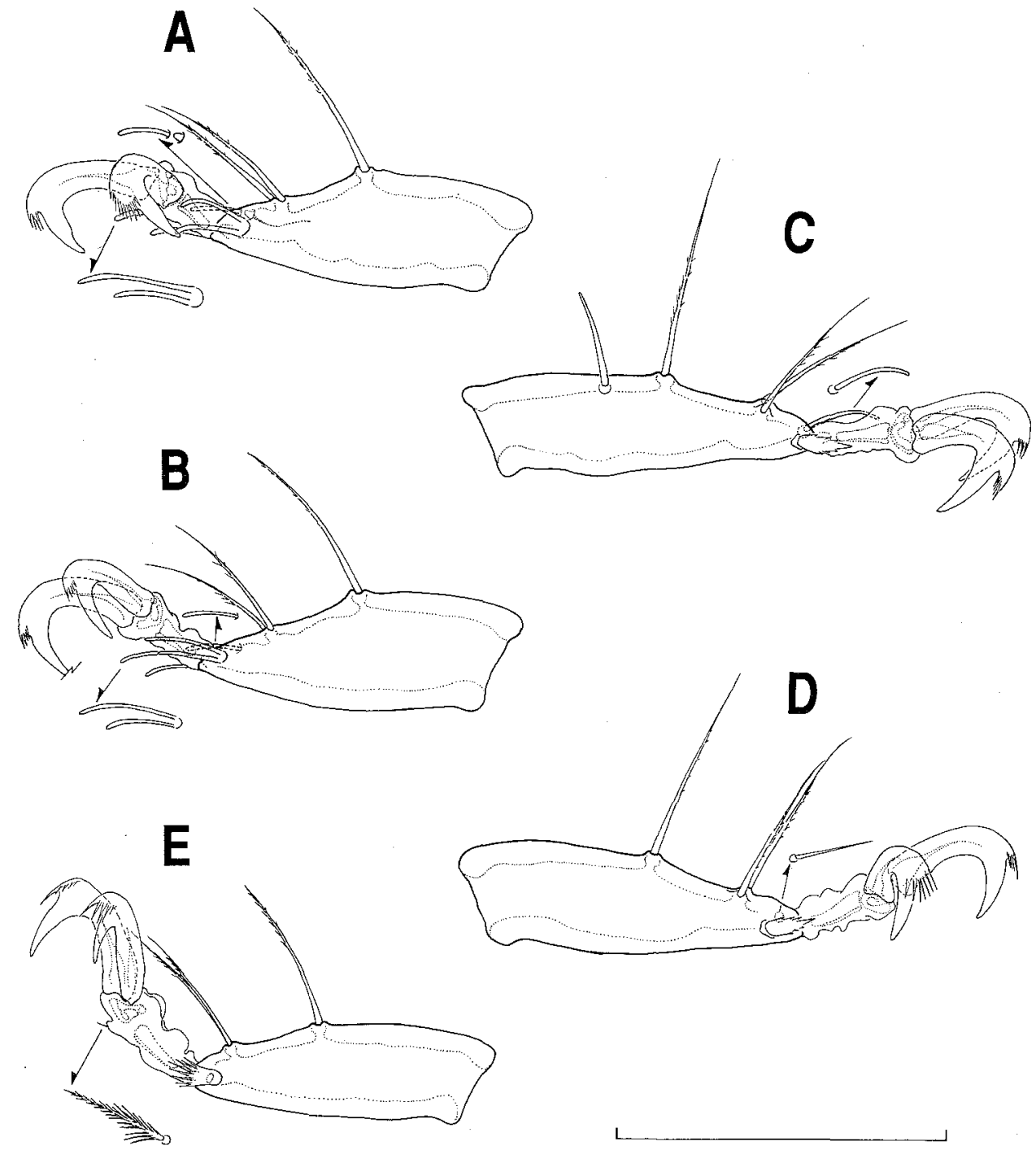

Fig. 57. Rhombognathus sinensis Bartsch, 1990, female. A, tarsus I (R); B, tarsus II (R); C, tarsus III (L); D, tarsus IV (L). Male. E, tarsus IV (R). Scale bar $=50 \mu \mathrm{m}$.

the female in essential respects except for character states of genitoanal region and chaetotaxy of tarsus IV.

Genitoanal region (Fig. 55B) furnished with a series of polygonal subsurface pores on each side of genital foramen, bearing 10 and 11 branched perigenital setae on each side of the foramen as arranged in Fig. 55B. Genital foramen $40 \mu \mathrm{m}$ long, $24 \mu \mathrm{m}$ wide. Subgenital setae two pairs on genital sclerites, arranged 2-0. Genital acetabula three pairs. Spermatophorotype (cf. Fig. 55B) $50 \mu \mathrm{m}$ long, $52 \mu \mathrm{m}$ wide, rhombic in form.

Tarsus IV (Fig. 57E) furnished with three dorsal setae (one faintly plumose seta on basal claw fossa, two weakly plumose seta on distal claw fossa) and two parambulacral setae (one long plumose proeuphathidium on posterior surface, one scaliform proeuphathidium on 
anterior surface).

Morphological variation and abnormality

The size range of the idiosoma, gnathosoma, and legs I-IV as follows.

Female $(\mathrm{n}=3)$. Idiosoma-length : $312-328 \mu \mathrm{m}$, -width : 192-200 $\mu \mathrm{m}$; gnathosoma-length : 72-74 $\mu \mathrm{m}$, -width : 60-64 $\mu \mathrm{m}$; leg-length : Leg I, 198-206 $\mu \mathrm{m}$; leg II, 184-192 $\mu \mathrm{m}$; leg III, 182 $-194 \mu \mathrm{m}$; leg IV, 180-192 $\mu \mathrm{m}$.

Male (n=2). Idiosoma-length : $280 \mu \mathrm{m}$, -width : 168-172 $\mu \mathrm{m}$; gnathosoma-length : $72-74$ $\mu \mathrm{m}$, -width : 56-60 $\mu \mathrm{m}$; leg-length : Leg I, 180-198 $\mu \mathrm{m}$; leg II, 174-192 $\mu \mathrm{m}$; leg III, 176-192 $\mu \mathrm{m}$; leg IV, 176-192 $\mu \mathrm{m}$.

The leg chaetotaxy varies among adult specimens $(n=5)$ as follows: Trochanters I-IV, 1-1-1-0 ; basifemora I-IV, 2-2-(1,2,3)-2 ; telofemora I-IV, 6-(6,7)-(3,4)-(4,5); genua I-IV, (4, 5)-(4,5)-(3,4)-3 ; tibiae I-IV, 5-5-5-5. As for large bipectinate setae: Genua I-IV, 0-0-0-0 ; tibiae I-IV, $2-1-(1,2)-(1,2)$.

The number of the perigenital setae on each side of the genital foramen varies from five to six in the female, 9 to 13 in the male.

\section{Remarks}

Rhombognathus sinensis is originally described by Bartsch (1990) from lower intertidal zone in the South China Sea. The specimens from Hokkaido, western North Pacific, are well consistent with the descriptions by Bartsch $(1990,1992)$. However, dorsal plates of specimens from Hokkaido are rather well developed than those of the specimens from Hong Kong, South China Sea. $R$. sinensis shares many significant character states with $R$. notops (Gosse, 1855), R. paranotops Bartsch, 1986, R. magnirostris Trouessart, 1889, R. ventralis Newell, 1984 and $R$. incertus sp. nov. However, $R$. sinensis is discernible from these congeners by the following character states: 1) dorsal plates are ornamented with round panels, 2) anterior dorsal plate is strongly protruded posteriorly, 3) ocular plate is nearly square in outline, 4) all dorsal setae are almost equal in length, 5) anterior epimeral plate has one adjunctive seta on each lateral margin, and 6) telofemora I-IV have $(1,2) / 5,2 /(4,5), 1 /(2,3), 1 /(3,4)$ ventral/dorsal setae.

Habitat-Intertidal zone: Algae - Gymnogongrus fabelliformis, Sargassum sp. in tide pool. Mussels - Mytilus edulis on ledge.

Distribution in Hokkaido-Oshoro.

\section{Rhombognathus tenuiformis sp. nov.}

[Japanese name: Hoso-kaisoudani]

(Figs. 58-61)

Type series. Holotype : Female, coarse sand on tidal line, intertidal, Oshoro (Shirikoshi), Japan Sea coast of Hokkaido, 13.iv.1989, H. Abé coll. Allotype: Male, data same as the holotype. Paratypes: 3 females, locality same as the holotype, 22.iii.1989, H. Abé coll.; 1 female and 2 males, data same as the holotype; 1 female, locality same as the holotype, 1.v.1989, H. Abé coll.

Female (holotype)

Idiosoma $300 \mu \mathrm{m}$ long, $144 \mu \mathrm{m}$ wide. Color in life dark green.

Dorsum (Fig. 58A): Dorsal plates faintly sclerotized and membranous cuticle very weakly striated. Ornamentation indistinct, and panels detectable only on PD. Canaliculi not clear. $\mathrm{AD}$ and $\mathrm{PD}$ separated by interval approximately two times as long as $\mathrm{AD}$-length. $\mathrm{AD}$ $70 \mu \mathrm{m}$ long, $70 \mu \mathrm{m}$ wide, weakly convex posteriorly, ornamented with weak areolation posteriorly, with a dorsal pore near each lateral margin. OC $96 \mu \mathrm{m}$ long, extending anteriorly to level of insertion of leg II, reaching posteriorly at level of insertion of leg III, furnished with 


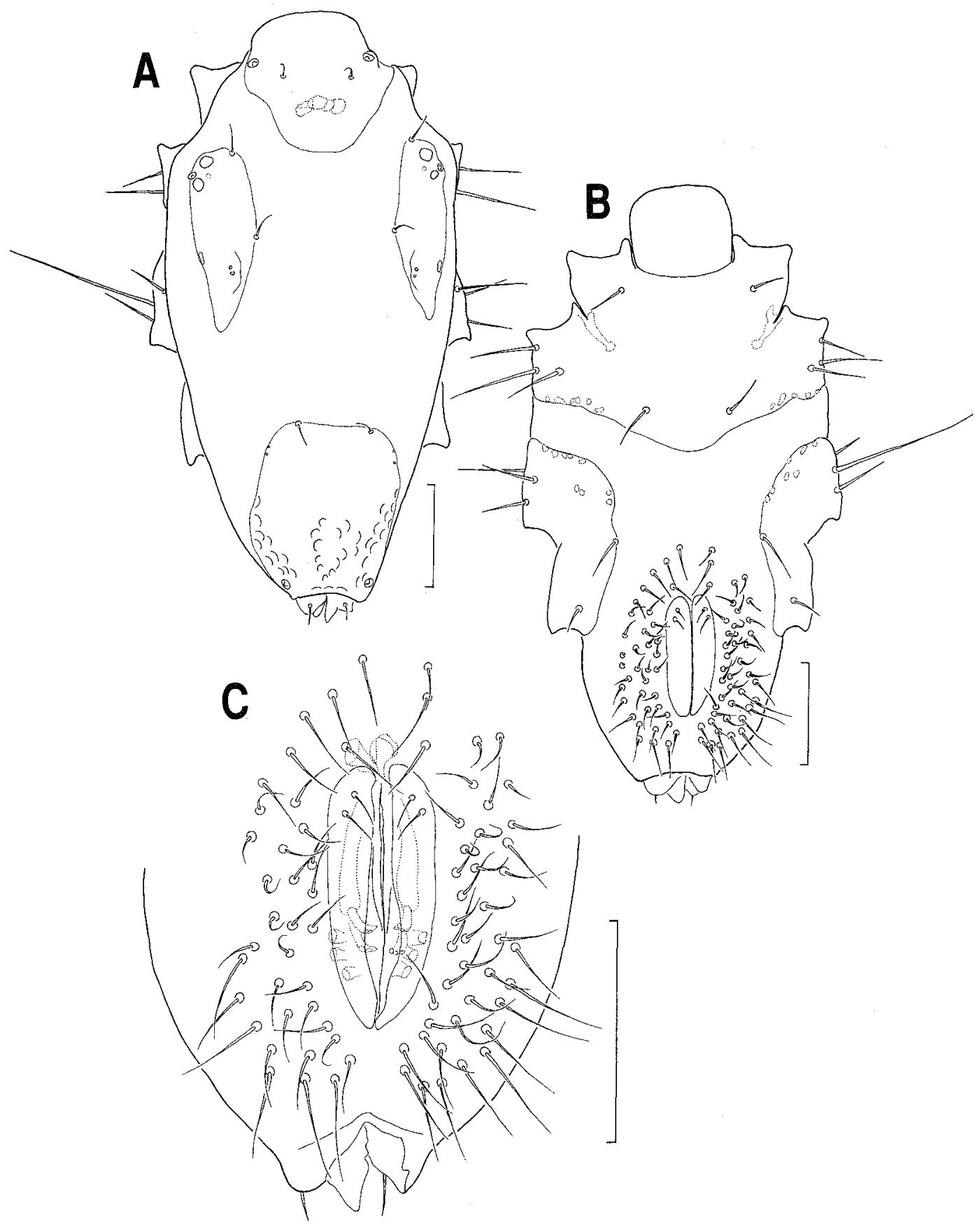

Fig. 58. Rhombognathus tenuiformis sp. nov., female (holotype). A, idiosoma (Ds); B, idiosoma (Vr) ; $\mathrm{C}$, genitoanal region. Scale bars $=50 \mu \mathrm{m}$. 


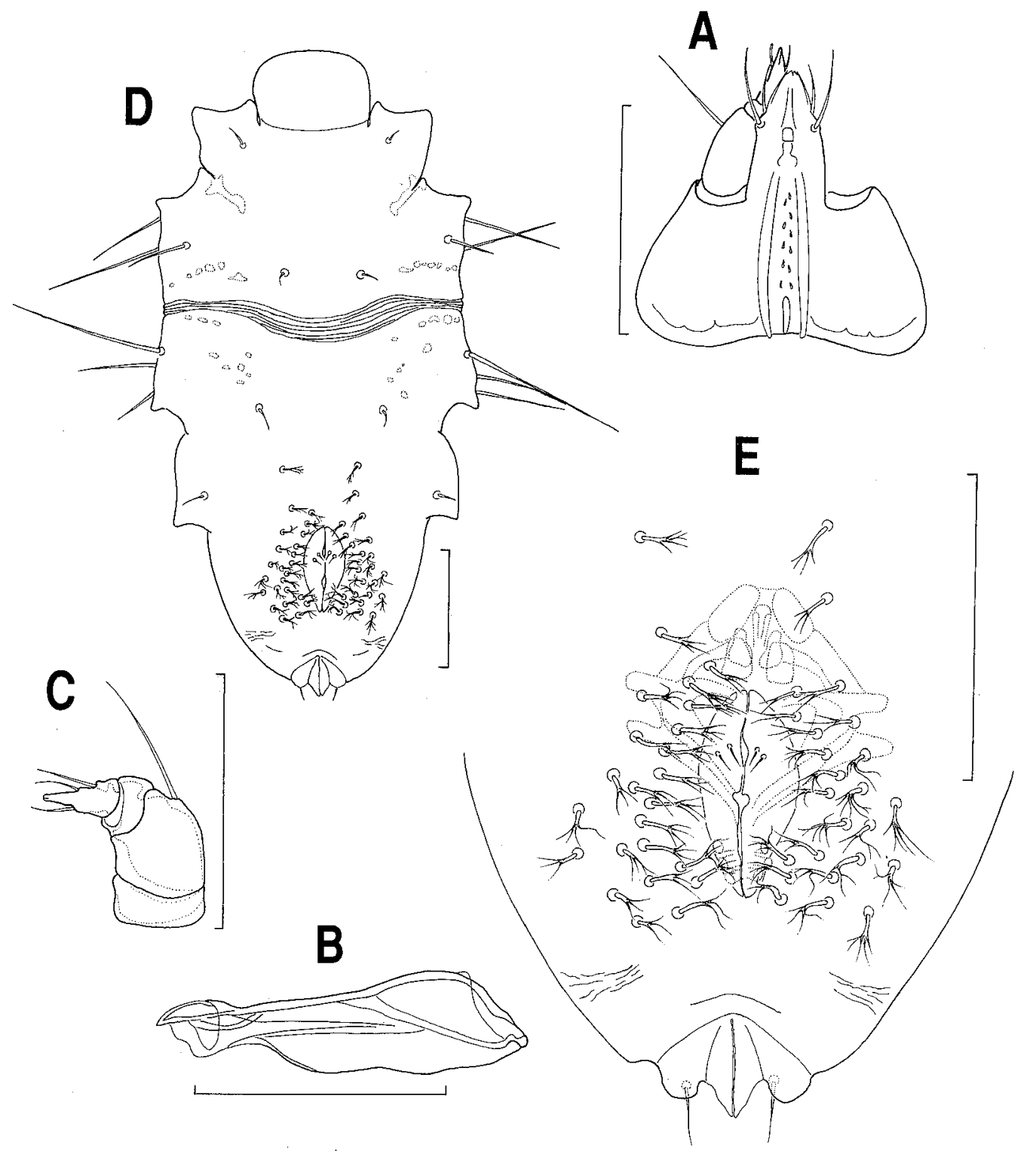

Fig. 59. Rhombognathus tenuiformis sp. nov., female (holotype). A, gnathosoma (Vr) (left palp omitted) ; B, chelicera (L) ; C, palp (L). Male (allotype). D, idiosoma (Vr) ; E, genitoanal region. Scale bars $=50 \mu \mathrm{m}$.

two corneae and one anterior polygonal pores, bearing one tiny pore-like structure at lateral margin and two tiny subsurface pores near posteromedial margin. PD $82 \mu \mathrm{m}$ long, $76 \mu \mathrm{m}$ wide, reaching anteriorly to level slightly anterior to insertion of leg IV, furnished with a dorsal pore near posterior margin on each side. Costae inconspicuous.

Chaetotaxy of dorsal region: Dorsal setae short. Setae ds-i on $A D$; ds-ii and ds-iii placed on lateral margin of OC; ds-iv on anterior margin of PD. Setae ds-v absent.

Venter (Fig. 58B) : Epimeral plates separated. Genitoanal region only weakly sclerot- 
ized, without distinct plate. Epimeral plates without reticulation. Anterior epimeral plate furnished with several subsurface pores posterolaterally, and with epimeral pore between insertions of leg I and leg II. Posterior epimeral plate furnished with some subsurface pores along anterior margin.

Chaetotaxy of epimeral region: Setae aes-i located at posteriorly to insertion of leg I; aes-ii-lat placed medially at level posterior to insertion of leg II; aes-ii-v placed most medially; aes-ii-adj located on lateral margins, each consisting of two setae; pes-iii-lat placed dorsolaterally on PE; pes-iii-v near lateral margins of PE; pes-iv-a placed on medial margins at level of insertion of leg III ; pes-iv-p located at level anterior to insertion of leg IV ; pes-iii-adj placed dorsolaterally, each consisting of one seta.

Genitoanal region (Fig. 58C): Genitoanal region sparsely scattered with perigenital setae. Genital foramen $60 \mu \mathrm{m}$ long, $24 \mu \mathrm{m}$ wide, placed anteriorly at level slightly anterior to insertion of leg IV. Genital sclerites band-like, with three pairs of internal genital acetabula. Spermatheca bilobed.

Chaetotaxy of genitoanal region: 35 and 41 filiform setae located on each side of genital foramen respectively as arranged in Fig. 58C. Subgenital setae filiform ; two pairs on genital sclerites, arranged 2-0. Adanal setae placed on anal papilla dorsally.

Gnathosoma (Fig. 59A) : $66 \mu \mathrm{m}$ long, $56 \mu \mathrm{m}$ wide, gnathosoma-length/idiosoma-length 0 . 22. Base, length/width 0.51 . Rostrum $36 \mu \mathrm{m}$ long, nearly lanceolate, not reaching to level of distal end of palp. Rostral setae two pairs as follows: Proximal pair long and robust, at swollen point ; distal pair short, at just anterior to proximal pair. Chelicera (Fig. 59B) with basal segment $60 \mu \mathrm{m}$ long, and movable digit $12 \mu \mathrm{m}$ long, bearing 11-12 minute denticles along dorsal edge. Fixed digit extending distally to mid level of dorsal edge of movable digit. Palp (Fig. 59C) $38 \mu \mathrm{m}$ long ; P-1 short and cylindrical ; P-2 longest and robust, with a long filiform seta distidorsally ; $\mathrm{P}-3$ short and cylindrical ; $\mathrm{P}-4$ conical, with three short and thick filiform setae intermediately.

Legs (Figs. 60A-D) : Length of legs I, II, III, IV $=170,162,188,188 \mu \mathrm{m}$ respectively. Ornamentation indistinct. Lateral claw with very faint accessory tooth.

Leg chaetotaxy as follows: Trochanters I-IV, 1-1-1-0; basifemora I-IV, 2-3-2-2 ; telofemora I-IV, 5-5-3-3; genua I-IV, 6-6-3-3; tibiae I-IV, 6-6-5-5. As for large bipectinate setae: Genua I-IV, 1-0-0-0 ; tibiae I-IV, 2-1-1-1. Tarsus I (Fig. 61A) with three dorsal setae, one solenidion, one famulus, and four parambulacral setae (paired doublet euphathidia). Solenidion long bacilliform on posterodorsal surface of claw fossa. Famulus papilliform with fine canaliculus at proximally to solenidion. Tarsus II (Fig. 61B) with three dorsal setae, one solenidion, and four parambulacral setae. Solenidion long bacilliform on posterodorsal surface of claw fossa. Tarsus III (Fig. 61C) with three dorsal setae and two parambulacral setae (one single euphathidium on posterior surface, one scaliform proeuphathidium on anterior surface). Tarsus IV (Fig. 61D) with three dorsal setae (one long filiform seta on basal claw fossa, one filiform seta on distal claw fossa, one fine filiform seta on anterodorsal surface) and two parambulacral setae (one fine filiform euphathidium on posterior surface, one scaliform proeuphathidium on anterior surface).

Male (allotype)

Idiosoma $280 \mu \mathrm{m}$ long, $132 \mu \mathrm{m}$ wide, gnathosoma-length/idiosoma-length 0.23 , resembling the female in essential respects except for character states of ventral plates and genitoanal region.

Venter (Fig. 59D) : Posterior epimeral plates and genitoanal plate fused into single plate. Epimeral plates without reticulation. Anterior epimeral plate furnished with several subsurface pores posterolaterally, and with urstigma between insertions of leg I and leg II on each side. Posterior epimeral region furnished with some subsurface pores along anterior margin. 


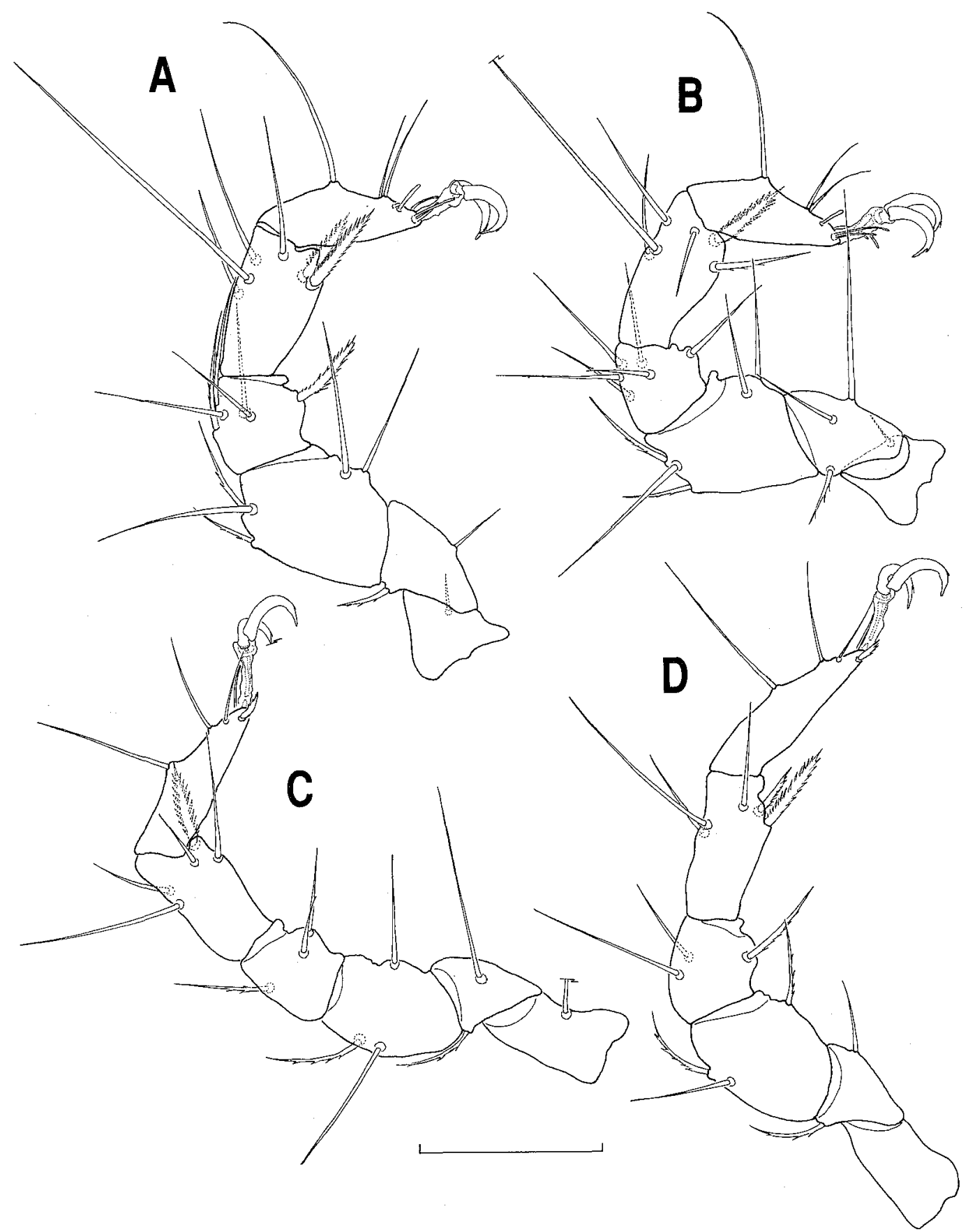

Fig. 60. Rhombognathus tenuiformis sp. nov., female (holotype). A, leg I (R); B, leg II (R); C, leg III (L); D, leg IV (L). Scale bar $=100 \mu \mathrm{m}$. 


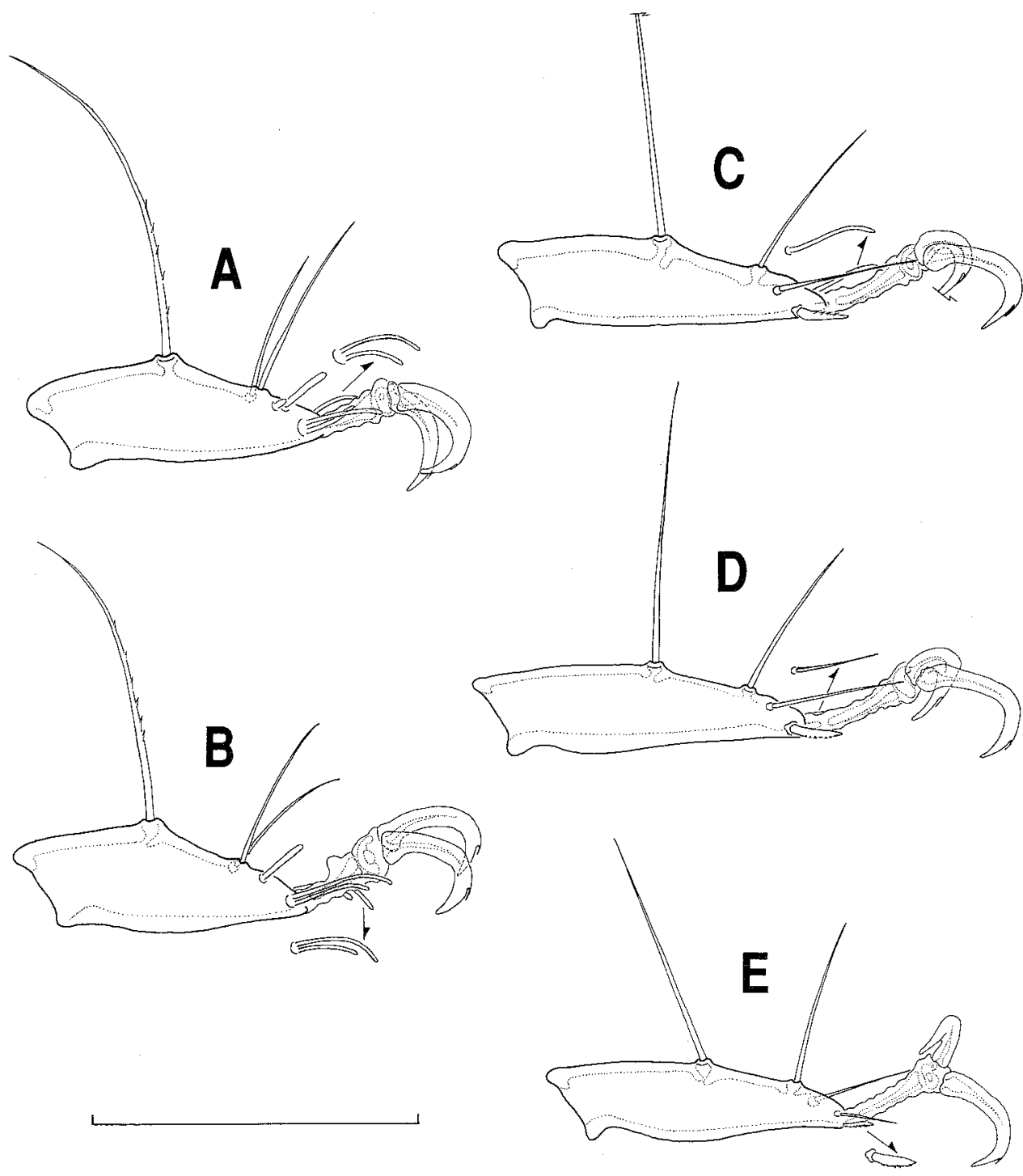

Fig. 61. Rhombognathus tenuiformis sp. nov., female (holotype). A, tarsus I (R); B, tarsus II (R); C, tarsus III (L) ; D, tarsus IV (L). Male (allotype). E, tarsus IV (R). Scale bar $=50 \mu \mathrm{m}$.

Genitoanal region (Fig. 59E) shortly incised laterally with membranous cuticle, bearing 24 branched perigenital setae on each side of genital foramen as arranged in Fig. 59E. Genital foramen $36 \mu \mathrm{m}$ long, $18 \mu \mathrm{m}$ wide. Subgenital setae two pairs on genital sclerites, arranged $2-0$. Genital acetabula three pairs. Spermatophorotype (cf. Fig. 59E) $50 \mu \mathrm{m}$ long, $50 \mu \mathrm{m}$ wide, rhombic.

Tarsus IV (Fig. 61E) same as that in the female.

Morphological variation and abnormality

The size range of the idiosoma, gnathosoma, and legs I-IV as follows. 
Female ( $\mathrm{n}=6$ ). Idiosoma-length : 288-352 $\mu \mathrm{m}$, -width : $140-192 \mu \mathrm{m}$; gnathosoma-length : 64-68 $\mu \mathrm{m}$, -width : 56-64 $\mu \mathrm{m}$; leg-length : Leg I, 170-176 $\mu \mathrm{m}$; leg II, 160-178 $\mu \mathrm{m}$; leg III, 176 $-188 \mu \mathrm{m}$; leg IV, 178-188 $\mu \mathrm{m}$.

Male $(\mathrm{n}=3)$. Idiosoma-length : 260-280 $\mu \mathrm{m}$, -width: 120-132 $\mu \mathrm{m}$; gnathosoma-length : 56-64 $\mu \mathrm{m}$, -width : 52-58 $\mu \mathrm{m}$; leg-length : Leg I, 158-172 $\mu \mathrm{m}$; leg II, 152-164 $\mu \mathrm{m}$; leg III, 158 $-166 \mu \mathrm{m}$; leg IV, $152-168 \mu \mathrm{m}$.

The leg chaetotaxy varies among adult specimens $(n=9)$ as follows: Trochanters I-IV, 1-1-1-0 ; basifemora I-IV, $2-3-2-2$; telofemora I-IV, $(5,6)-(5,6)-(3,4)-3$; genua I-IV, $6-(5,6)-$ $3-3$; tibiae I-IV, $6-(5,6)-5-(4,5)$.

The number of the perigenital setae on each side of the genital foramen varies from 35 to 45 in the female, 22 to 24 in the male.

\section{Remarks}

Rhombognathus tenuiformis is characterized by 1) very weakly sclerotized dorsal plates, 2) the female with three ventral, and the male with two ventral plates, and 3) tarsus III with only three dorsal setae.

The majority of Rhombognathus species have four dorsal setae on tarsus III, and only $R$. hirtellus Bartsch, 1992 has been so far known as an unique species which has three setae on tarsus III. R. tenuiformis is the second species characterized by this unique setation of tarsus III. The present species is, however, easily discernible from $R$. hirtellus by the possession of separated ventral plates.

$R$. tenuiformis has considerably slender body and weakly sclerotized plates. Arenicolous halacarids, e.g. Anomalohalacarus, Arenihalacarus, Australacarus, and Halacaroides usually have the similar condition in body shape and idiosomal plates. Such the characteristics might be acquired in the evolution of halacarids for an adaptation to the interstitial environment.

The specific epithet is derived from the tenuous form of the body.

Habitat-Intertidal zone: Coarse sandy sediment.

Distribution in Hokkaido - Oshoro.

\section{Rhombognathus teurinus sp. nov.} [Japanese name: Teuri-kaisoudani]

(Figs. 62-65)

Type series. Holotype: Female, coarse shelly sand at a depth of 10-20 m, subtidal, Teuri Isl., Japan Sea coast of Hokkaido, 18.ii.1989, H. Abé coll. Allotype: Male, data same as the holotype. Paratypes: 4 females, 4 males and 4 tritonymphs, data same as the holotype.

Female (holotype)

Idiosoma $320 \mu \mathrm{m}$ long, $192 \mu \mathrm{m}$ wide. Color in life dark green.

Dorsum (Fig. 62A) : Dorsal plate uniformly ornamented with reticulated panels (Fig. 62C), and partly with fine canaliculi. AD and PD separated by interval less than AD-length. AD $78 \mu \mathrm{m}$ long, $98 \mu \mathrm{m}$ wide, truncated posteriorly, ornamented with distinct areolation posteriorly, and with a dorsal pore near each lateral margin. OC $92 \mu \mathrm{m}$ long, extending anteriorly to level of posterior margin of $\mathrm{AD}$, reaching posteriorly at level of insertion of leg III, furnished with two small corneae and two polygonal pores, bearing one tiny pore-like structure on lateral margin, one maze-like subsurface pore medially to corneae, and two and three tiny subsurface pores near each posteromedial margin respectively. Areolation indistinct. PD $198 \mu \mathrm{m}$ long, $124 \mu \mathrm{m}$ wide, furnished with a small subsurface pore on anterolateral margin, and with dorsal pore on posterior margin on each side. Costae absent.

Chaetotaxy of dorsal region: Dorsal setae short. Setae ds-i on $\mathrm{AD}$; ds-ii and ds-iii each 


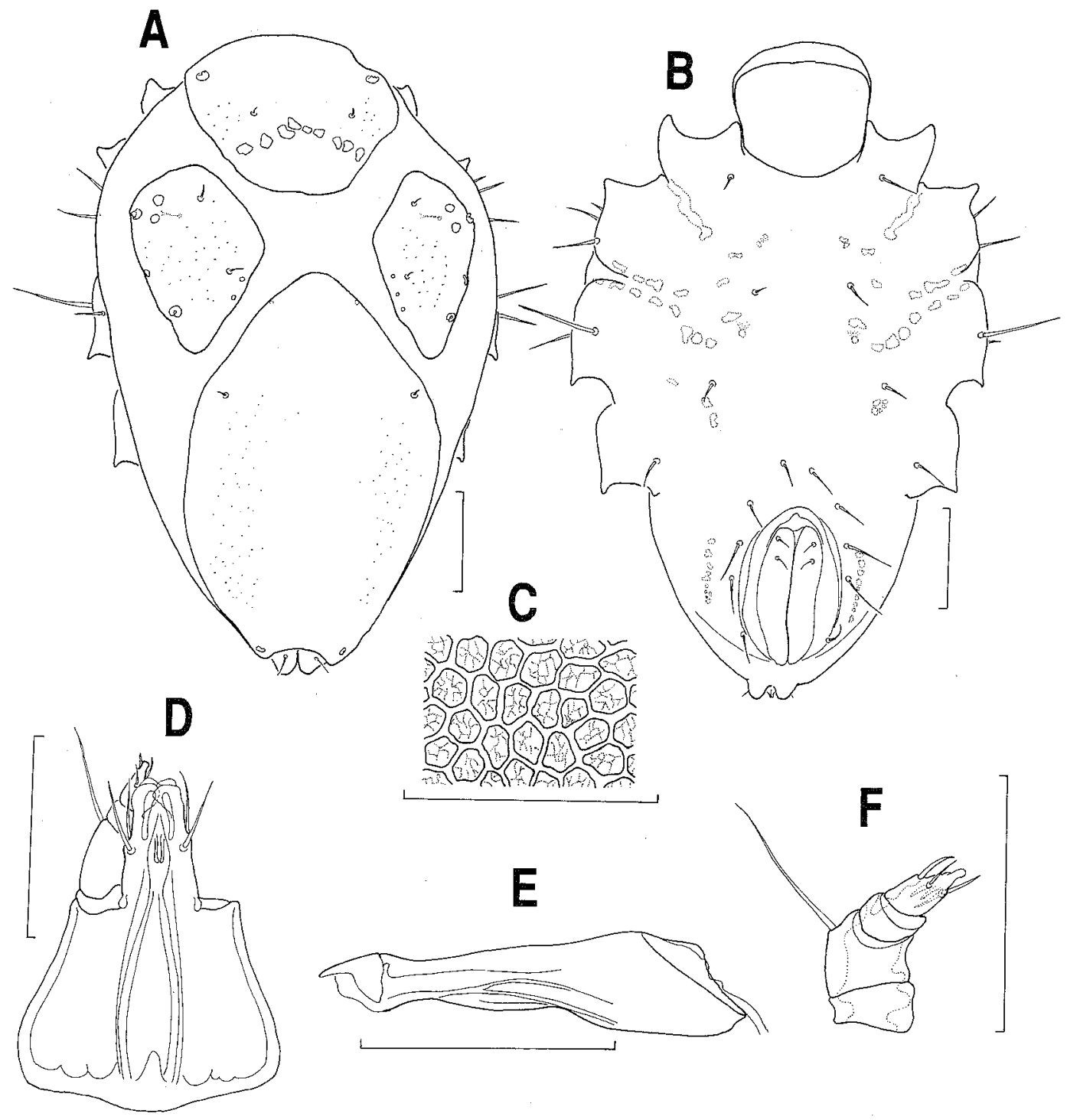

Fig. 62. Rhombognathus teurinus sp. nov., female (holotype). A, idiosoma (Ds); B, idiosoma (Vr); C, panels on PD ; D, gnathosoma (Vr) (left palp omitted) ; E, chelicera (R) ; F, palp (R). Scale bars $=50$ $\mu \mathrm{m}$.

on $\mathrm{OC}$; ds-iv on PD near anterolateral margin. Setae ds-v absent.

Venter (Fig. 62B) : Epimeral and genitoanal plates fused to form a single plate. Ventral plates are entirely reticulated with faint panels. Epimeral-region furnished with several subsurface pores medially, and with epimeral pore between insertions of leg I and leg II on each side, faintly incised laterally with membranous cuticle bordering several subsurface pores between insertions of leg II and leg III.

Chaetotaxy of epimeral region: Setae aes-i located posteriorly to camerostome; aes-iilat placed at lateral margin; aes-ii-v placed most medially at level of lateral incision; 


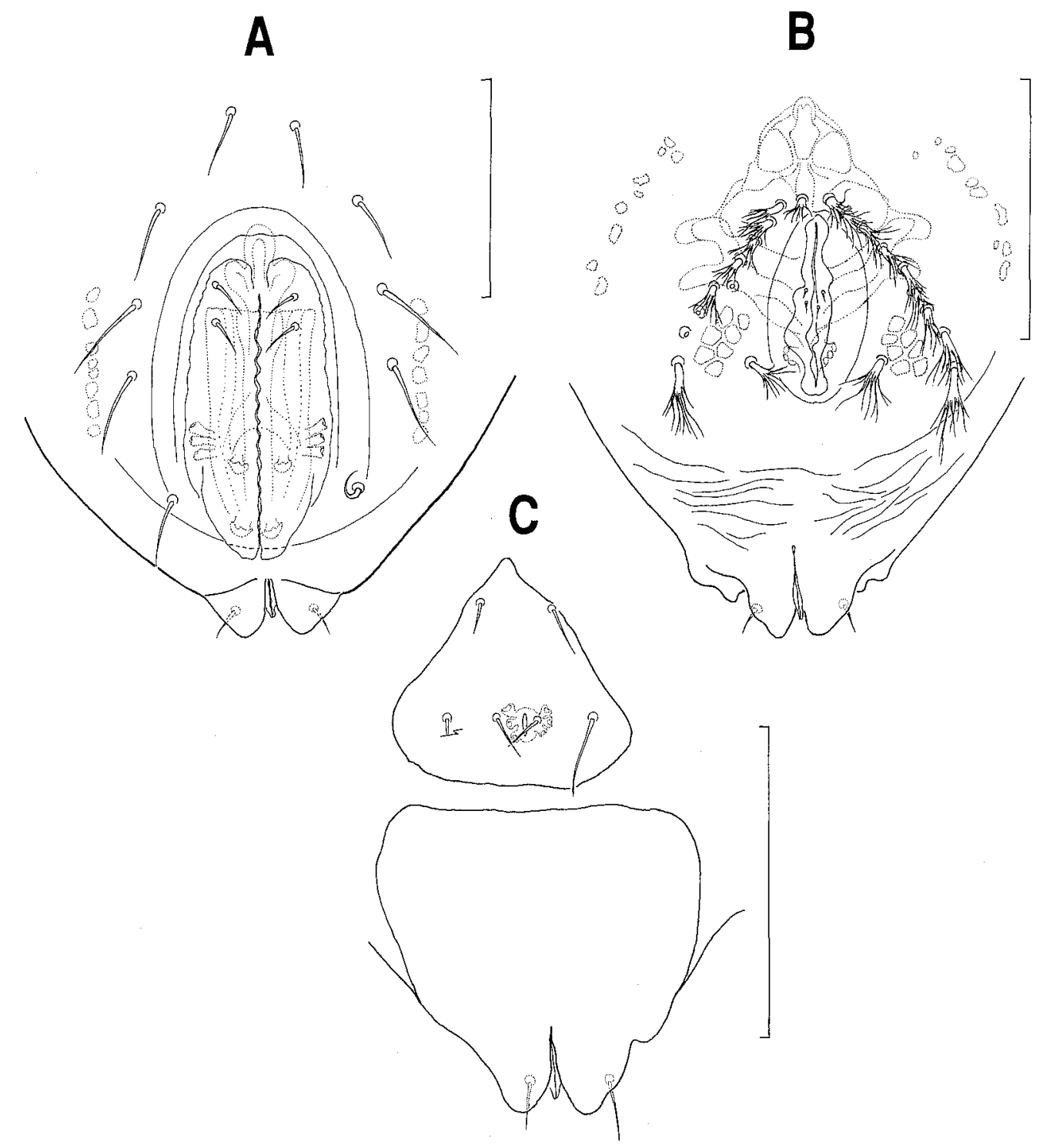

Fig. 63. Rhombognathus teurinus sp. nov., genitoanal regions. A, female (holotype) ; B, male (allotype) ; C, tritonymph (paratype). Scale bars $=50 \mu \mathrm{m}$.

aes-ii-adj located on dorsolateral margins, each consisting of one or two setae; pes-iii-lat placed dorsally on posterior epimeral region; pes-iii-v near lateral margins ; pes-iv-a placed medially at level of insertion of leg III ; pes-iv-p located at level anterior to insertion of leg IV ; pes-iii-adj absent.

Genitoanal region (Fig. 63A): Genitoanal region without distinct lateral incisions. Genital foramen $72 \mu \mathrm{m}$ long, $44 \mu \mathrm{m}$ wide, occupying from level posterior to insertion of leg IV to level anterior to anal foramen. Genital sclerites band-like, with three pairs of internal genital acetabula. Spermatheca unclear.

Chaetotaxy of genitoanal region: Five pairs of filiform perigenital setae located at each 


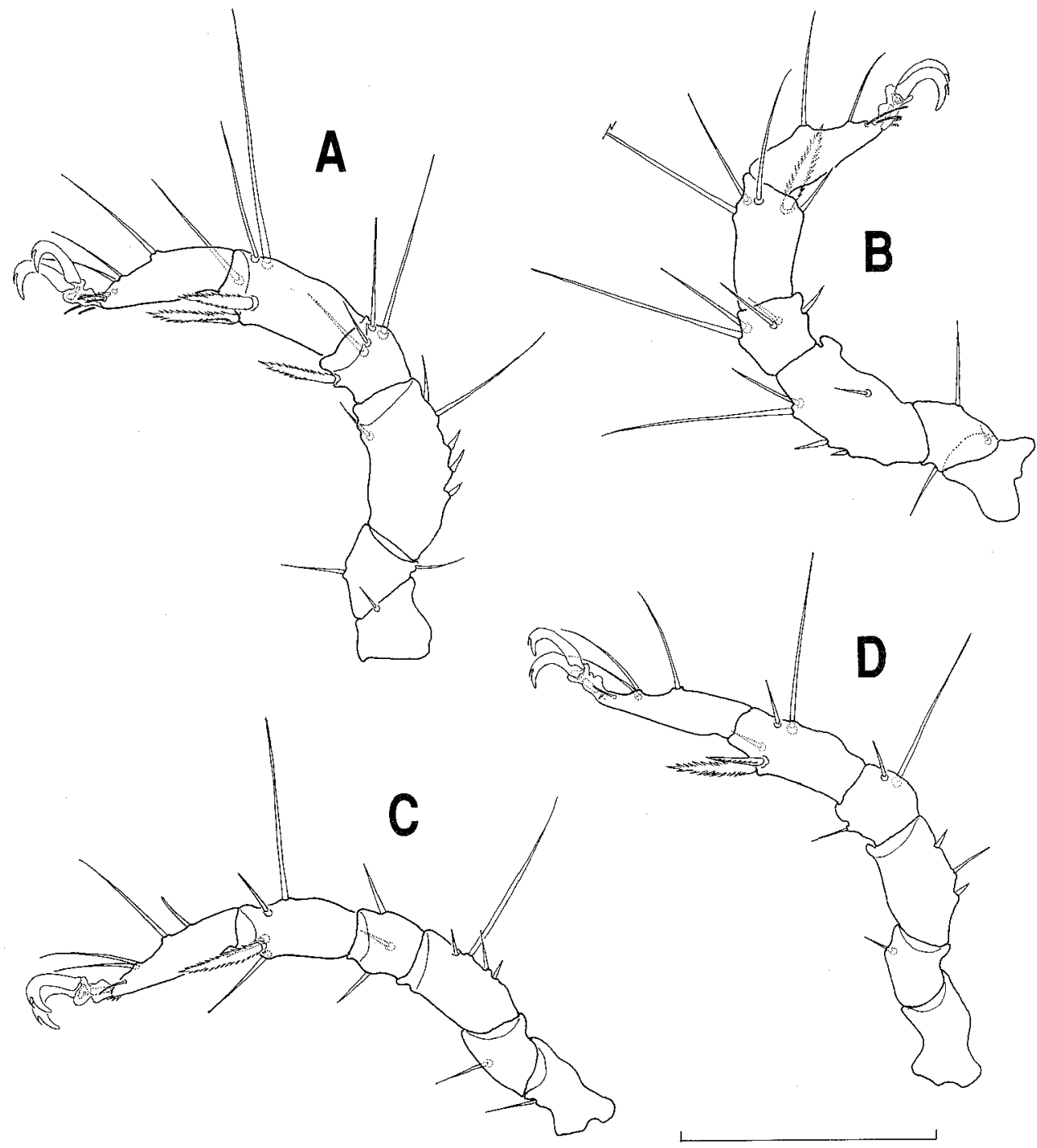

Fig. 64. Rhombognathus teurinus sp. nov., female (holotype). A, leg I (R); B, leg II (R) ; C, leg III (L) ; D, leg IV (L). Scale bar $=100 \mu \mathrm{m}$.

side of genital foramen as arranged in Fig. 63A. Subgenital setae filiform; two pairs on genital sclerites, arranged 2-0. Adanal setae placed on anal papilla dorsoproximally.

Gnathosoma (Fig. 62D) : $80 \mu \mathrm{m}$ long, $64 \mu \mathrm{m}$ wide, gnathosoma-length/idiosoma-length 0 . 25. Base, length/width 1.30. Rostrum $30 \mu \mathrm{m}$ long, nearly rectangular, furnished with membranous terminal lamellae. Rostral setae two pairs as follows: Proximal pair long and robust, at swollen point ; distal pair short, at just anterior to proximal pair. Chelicera (Fig. 62E) with basal segment $68 \mu \mathrm{m}$ long, and movable digit $12 \mu \mathrm{m}$ long, without clear denticles along dorsal edge. Fixed digit extending distally to mid level of movable digit. Palp (Fig. 62F) $42 \mu \mathrm{m}$ long ; $\mathrm{P}-1$ short and cylindrical ; $\mathrm{P}-2$ longest, with a long filiform seta distidorsally ; P-3 short and cylindrical; P-4 conical, with two filiform, and one blade-like setae 

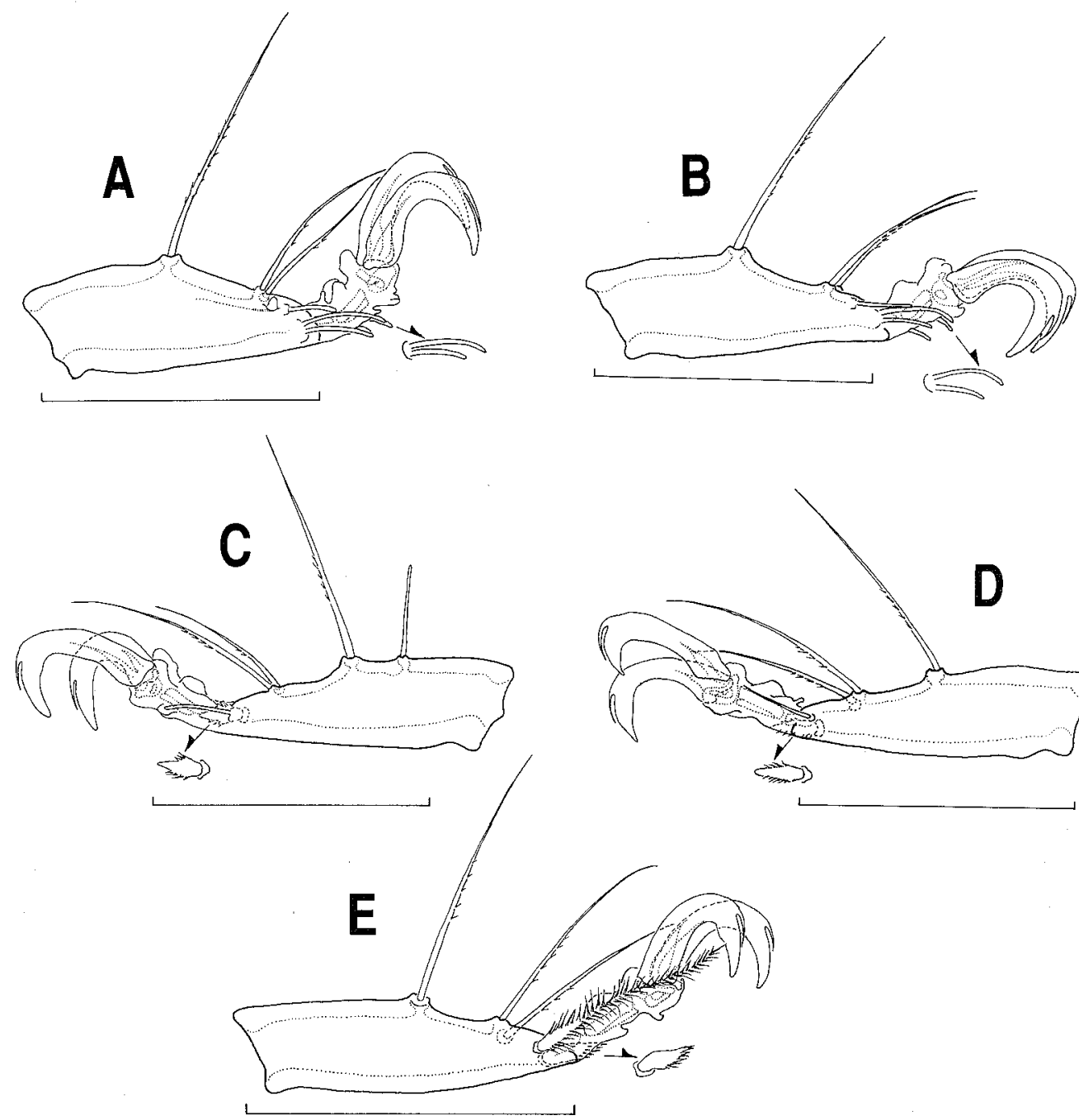

Fig. 65. Rhombognathus teurinus sp. nov., female (holotype). A, tarsus I (R); B, tarsus II (R); C, tarsus III (L) ; D, tarsus IV (L). Male (allotype). E, tarsus IV (R). Scale bar $=50 \mu \mathrm{m}$.

intermediately.

Legs (Figs. 64A-D) : Length of legs I, II, III, IV $=216,210,210,220 \mu \mathrm{m}$ respectively. Ornamentation indistinct. Lateral claw with two or three long delicate teeth.

Leg chaetotaxy as follows: Trochanters I-IV, 1-1-1-0; basifemora I-IV, 2-2-1-1; telofemora I-IV, 6-5-4-3; genua I-IV, 5-5-3-3; tibiae I-IV, 5-5-5-5. As for large bipectinate setae: Genua I-IV, 1-0-0-0; tibiae I-IV, 2-1-1-2 (one seta is less pectinated). Tarsus I (Fig. 65A) with three dorsal setae, one solenidion, one famulus, and four parambulacral setae (paired doublet euphathidia). Solenidion long bacilliform on posterodorsal surface of claw fossa. Famulus papilliform with fine canaliculus at just proximally to solenidion. Tarsus II (Fig. 65B) with three dorsal setae, one solenidion, and four parambulacral setae. Solenidion long bacilliform on posterodorsal surface of claw fossa. Tarsus III (Fig. 65C) with four dorsal setae and two parambulacral setae (one single euphathidium on posterior surface, 
one scaliform proeuphathidium on anterior surface). Tarsus IV (Fig. 65D) with three dorsal setae (one long faintly plumose seta on basal claw fossa, two weakly plumose seta on distal claw fossa) and two parambulacral setae (one filiform euphathidium on posterior surface, one scaliform proeuphathidium on anterior surface).

Male (allotype)

Idiosoma $288 \mu \mathrm{m}$ long, $148 \mu \mathrm{m}$ wide, gnathosoma-length/idiosoma-length 0.24 , resembling the female in essential respects except for character states of genitoanal region and chaetotaxy of tarsus IV.

Genitoanal region (Fig. 63B) furnished with a series of polygonal subsurface pores on each side of genital foramen, bearing 10 and 11 branched perigenital setae on each side of the foramen as arranged in Fig. 63B. Genital foramen $36 \mu \mathrm{m}$ long, $16 \mu \mathrm{m}$ wide. Subgenital setae two pairs on genital sclerites, arranged 2-0. Genital acetabula three pairs. Spermatophorotype (cf. Fig. 63B) $46 \mu \mathrm{m}$ long, $46 \mu \mathrm{m}$ wide, rhombic in form.

Tarsus IV (Fig. 65E) furnished with three dorsal setae (one long faintly plumose seta on basal claw fossa, two weakly plumose seta on distal claw fossa) and two parambulacral setae (one long plumose proeuphathidium on posterior surface, one scaliform proeuphathidium on anterior surface).

Tritonymph (paratype)

Idiosoma $232 \mu \mathrm{m}$ long, $128 \mu \mathrm{m}$ wide, gnathosoma-length/idiosoma-length 0.25 .

Dorsum : AD $72 \mu \mathrm{m}$ long, $78 \mu \mathrm{m}$ wide. PD $110 \mu \mathrm{m}$ long, $76 \mu \mathrm{m}$ wide, protruded anteriorly, furnished with one dorsal seta. $\mathrm{AD}$ and $\mathrm{PD}$ separated by interval less than $\mathrm{AD}$-length. $\mathrm{OC}$ $50 \mu \mathrm{m}$ long.

Venter: AE $74 \mu \mathrm{m}$ long, $124 \mu \mathrm{m}$ wide, furnished with one aes-ii-adj on each lateral margin. A pair of small subsurface pores placed on membranous cuticle posteriorly to $\mathrm{AE}$. PE $80 \mu \mathrm{m}$ long, furnished with several subsurface pores along anteromedial margin. Pes-iiiadj absent.

Genitoanal region (Fig. 63C) : Genital plate $34 \mu \mathrm{m}$ long, $36 \mu \mathrm{m}$ wide, subtriangular in shape, furnished with two pairs of perigenital, and one pair of subgenital setae. Primordial genital slit with three pairs of internal genital acetabula. Anal plate $32 \mu \mathrm{m}$ long, nearly truncated anteriorly.

Legs: Length of legs I, II, III, IV $=164,156,156,160 \mu \mathrm{m}$ respectively. Leg chaetotaxy of trochanters I-IV , 1-1-1-0; basifemora I-IV , 2-2-1-1; telofemora I-IV, 4-4-3-2 ; genua I-IV, $5-5-3-3$; tibiae I-IV , 5-4-5-5. Distinct bipectinate setae on genua I-IV, $1-0-0-0$; tibiae I-IV, $2-1-1-2$ (one seta is less pectinated).

Morphological variation and abnormality

The size range of the idiosoma, gnathosoma, and legs I-IV as follows.

Female $(\mathrm{n}=5)$. Idiosoma-length : $304-328 \mu \mathrm{m}$, -width : $172-192 \mu \mathrm{m}$; gnathosoma-length : 74-80 $\mu \mathrm{m}$, -width : 56-64 $\mu \mathrm{m}$; leg-length : Leg I, 208-232 $\mu \mathrm{m}$; leg II, $210-214 \mu \mathrm{m}$; leg III, 200 $-212 \mu \mathrm{m}$; leg IV, 200-222 $\mu \mathrm{m}$.

Male $(\mathrm{n}=5)$. Idiosoma-length : 284-308 $\mu \mathrm{m}$, -width : $148-180 \mu \mathrm{m}$; gnathosoma-length : 68-74 $\mu \mathrm{m}$, -width : 50-60 $\mu \mathrm{m}$; leg-length : Leg I, 198-222 $\mu \mathrm{m}$; leg II, $188-210 \mu \mathrm{m}$; leg III, 182 $-210 \mu \mathrm{m} ;$ leg IV, $184-212 \mu \mathrm{m}$.

Tritonymph $(\mathrm{n}=4)$. Idiosoma-length : $232-236 \mu \mathrm{m}$, -width : $128-136 \mu \mathrm{m}$; gnathosomalength : 58-66 $\mu \mathrm{m}$, -width : 48-54 $\mu \mathrm{m}$; leg-length: Leg I, 164-186 $\mu \mathrm{m}$; leg II, 136-172 $\mu \mathrm{m}$; leg III, $150-168 \mu \mathrm{m}$; leg IV, 146-168 $\mu \mathrm{m}$.

The leg chaetotaxy varies as follows.

Adult $(n=10)$ : Trochanters I-IV, 1-1-1-0 ; basifemora I-IV, 2-2-1-1; telofemora I-IV, $(5,6)-(5,6)-(3,4)-(3,4)$; genua I-IV, 5-(4,5)-3-(3,4); tibiae I-IV, $(5,6)-5-5-(5,6)$. 
Tritonymph $(n=4)$ : Trochanters I-IV , 1-1-1-0; basifemora I-IV, 2-2-1-1; telofemora I -IV, 4-4-3-2 ; genua I-IV, 5-(4,5)-3-3; tibiae I-IV, 5-(4,5)-5-5.

The number of the setae aes-ii-adj varies from one to two. The number of the perigenital setae on each side of the genital foramen varies from five to seven in the female, 10 to 16 in the male. Basilar perigenital setae in the male varies from one to three.

Remarks

Among Rhombognathus species characterized by having five perigenital setae in the female, $R$. teurinus closely resembles $R$. neptunellus Bartsch, 1992 in the characteristics of that 1) posteriorly pointed idiosoma, 2) clearly and uniformly reticulated dorsal plates, 3) posterior dorsal plate with one pair of dorsal setae, 4) the number and the arrangement of perigenital setae in adults, 5) almost parallel-sided rostrum, 6) lateral claw with a long accessory process bearing two or three teeth. But, $R$. teurinus is discernible from $R$. neptunellus by the following characters (corresponding condition in the latter species in parentheses) : 1) anterior dorsal plate not longer than wide (clearly longer than wide), 2) all dorsal setae short (setae ds-i distinctly stronger than the other setae), 3) anterior margin of posterior dorsal plate strongly protruded (rounded), 4) adanal setae placed dorsally on anal papilla (placed laterally), 5) telofemora of legs III and IV without ventral setae, and genua I to IV with 1-0-0-0 bipectinate setae (telofemora of legs III and IV with ventral setae, and genua I-IV without bipectinate setae). R. teurinus and $R$. neptunellus also differ in body size: $R$. teurinus, $304-328 \mu \mathrm{m}$ in the female, $284-308 \mu \mathrm{m}$ in the male ; $R$. neptunellus, $213-252 \mu \mathrm{m}$ in the female, $222 \mu \mathrm{m}$ in the male. The size range, however, is based only on three females and single male in $R$. neptunellus. Therefore, this difference is possibly attributable to the sampling errors due to the small sample size.

$R$. teurinus is also similar to R. semiarmatus Bartsch, 1983, and $R$. sinensis Bartsch, 1990. But, $R$. teurinus is discernible from $R$. semiarmatus by the clearly reticulated dorsal plates, telofemora I to IV with $1 /(4,5), 1 /(4,5), 0 /(3,4), 0 /(3,4)$ ventral/dorsal setae, and the presence of a large bipectinate seta on the genu of leg $\mathrm{I}$, and from $R$. sinensis by the absence of adjunctive setae on posterior epimeral plate, accessory process with long delicate two or three teeth, and the presence of a large bipectinate seta on the genu of leg I.

$R$. teurinus was found only from the sandy sediment at subtidal zone, and is considered to be an arenicolous dweller.

The specific epithet is derived from the type locality "Teuri Island".

Habitat-Subtidal zone: Coarse shelly sand at a depth of 10-20 m.

Distribution in Hokkaido-Teuri Island.

\section{Regional Distribution Pattern and Substrate Preference of the Rhombognathines in Hokkaido}

There have been a number of studies on the local distribution of halacarid mites (Lohmann, 1889; Viets, 1927a, 1927b; Newell, 1947; Moore, 1973; Bartsch \& Schmidt, 1979). Several studies were also carried out for the purpose of examining faunal association between halacarids and particular types of substrates (cf. Colman, 1939; Wieser, 1952 ; Bartsch, 1974a, 1978, 1979b, 1982, 1989). Besides, Pugh \& King (1985) and Pugh \& Bartsch (1993) investigated the association of halacarids with algal species by using Yates' corrected Chi-squared analysis (Yates, 1934), and concluded that several British rhombognathines were associated with particular species of algae.

These investigations, however, dealt with the North Atlantic species, and no comprehensive ecological survey has been carried out in the Pacific Ocean region. In this section, the distribution of the rhombognathines in Hokkaido with respect to the following two kinds of 
Table 2. Localities where 16 species of rhombognathines were collected in Hokkaido. + : occurrence.

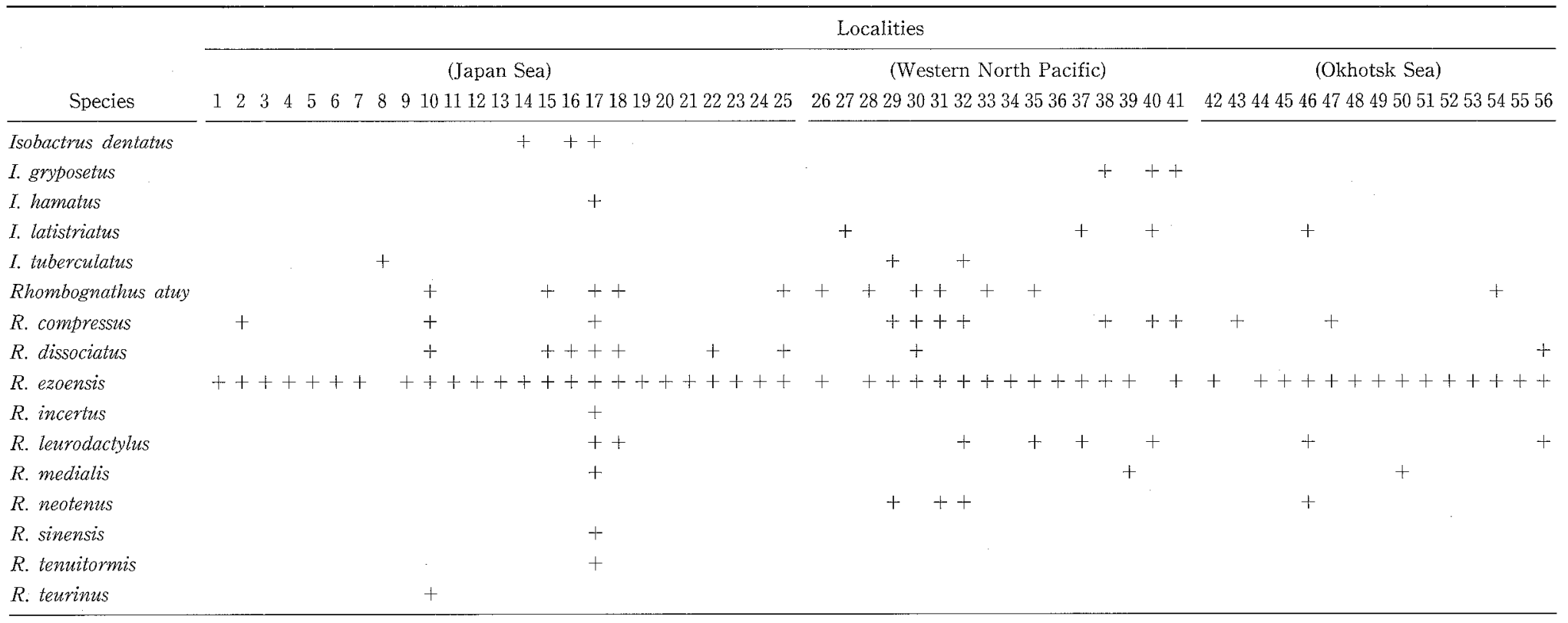


Table 3. Substrates from which 16 species of rhombognathines were collected in Hokkaido. +: occurrence.

\begin{tabular}{|c|c|c|c|c|c|c|c|c|c|c|c|c|c|c|c|}
\hline \multirow[b]{2}{*}{ Substrates } & \multicolumn{15}{|c|}{ Rhombognathine species } \\
\hline & 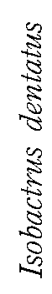 & 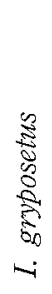 & 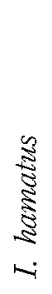 & 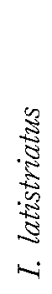 & 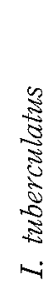 & 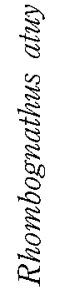 & 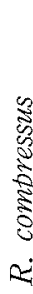 & 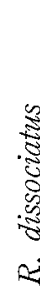 & 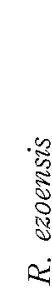 & 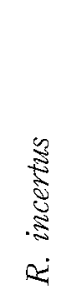 & 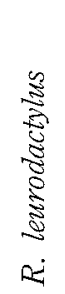 & 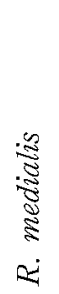 & 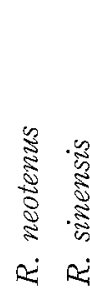 & 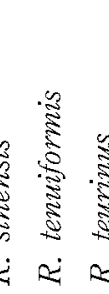 & 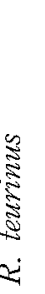 \\
\hline $\begin{array}{l}\text { Phaeophyceae } \\
\text { Sargassum thunbergii } \\
\text { Sargassum confusum } \\
\text { Sargassum fulvellum } \\
\text { Sargassum sagamianum } \\
\text { Sargassum spp. } \\
\text { Pelvetia wrightii } \\
\text { Agarum cribrosum } \\
\text { Fucus evanescens } \\
\text { Cystoseira hakodatensis } \\
\text { Dictyopteris divaricata } \\
\text { Coccophora longsdorfii } \\
\text { Desmarestia ligulata } \\
\text { Ectocarpus siliculosus } \\
\text { Laminalia angustata }\end{array}$ & + & $\begin{array}{l}+ \\
+\end{array}$ & + & + & & $\begin{array}{l}+ \\
+ \\
+ \\
+ \\
+\end{array}$ & $\begin{array}{l}+ \\
+\end{array}$ & $\begin{array}{l}+ \\
+ \\
+ \\
+ \\
+\end{array}$ & $\begin{array}{l}+ \\
+ \\
+ \\
+ \\
+ \\
+ \\
+ \\
+ \\
+ \\
+ \\
+\end{array}$ & & $\begin{array}{l}+ \\
+\end{array}$ & $\begin{array}{l}+ \\
+ \\
+\end{array}$ & + & & \\
\hline $\begin{array}{l}\text { Florideophyceae } \\
\text { Corallina pilulifera } \\
\text { Corallina spp. } \\
\text { Neorhodomela aculeata } \\
\text { Gymnogongrus flabelliformis } \\
\text { Tichocarpus crinitus } \\
\text { Rhodymenia palmata } \\
\text { Lohmentaria hakodatensis } \\
\text { Gloiopeltis furcata } \\
\text { Polysiphonia spp. } \\
\end{array}$ & + & & & + & & $\begin{array}{l}+ \\
+ \\
+\end{array}$ & & + & $\begin{array}{l}+ \\
+ \\
+ \\
+ \\
+ \\
+\end{array}$ & + & + & & + & & \\
\hline $\begin{array}{l}\text { Chlorophyceae } \\
\text { Ulva pertusa } \\
\text { Enteromorpha intestinalis } \\
\text { Enteromorpha compressa }\end{array}$ & & & & & + & + & & $\begin{array}{l}+ \\
+\end{array}$ & $\begin{array}{l}+ \\
+ \\
+\end{array}$ & & + & & + & & \\
\hline $\begin{array}{l}\text { Monocotyledoneae } \\
\text { Zostera marina } \\
\text { Phyllospadix iwatensis }\end{array}$ & & & & & & & + & + & $\begin{array}{l}+ \\
+ \\
+\end{array}$ & & & & & & \\
\hline $\begin{array}{l}\text { Pelecypoda } \\
\text { Mytilus edulis } \\
\text { Septifer virgatus }\end{array}$ & + & & & & + & $\begin{array}{l}+ \\
+\end{array}$ & & $\begin{array}{r}+ \\
+\end{array}$ & + & & + & & $+t$ & & \\
\hline $\begin{array}{l}\text { Maxillopoda } \\
\text { Balanus cariosus }\end{array}$ & & & & & & + & + & & + & & & & + & & \\
\hline $\begin{array}{l}\text { Polychaeta } \\
\text { Pseudopotamilla occelata }\end{array}$ & & & & & & + & & + & & & & & & & \\
\hline Sand & & & & & + & + & & + & I & & & + & + & $+\quad+$ & \\
\hline$\overline{\text { Stone }}$ & & & & & & & & + & & & & & & & \\
\hline Detritus & & & & & & & & & & & & & & & \\
\hline
\end{tabular}


Table 4. Chi-square decomposition of substrate-species correspondence.

\begin{tabular}{cc}
\hline Chi-squares & Percents \\
\hline 75.1222 & 19.05 \\
68.0032 & 17.24 \\
51.2398 & 12.99 \\
43.3427 & 10.99 \\
35.3418 & 8.96 \\
27.5526 & 6.99 \\
22.9937 & 5.83 \\
18.6235 & 4.72 \\
14.3342 & 3.63 \\
12.8466 & 3.26 \\
9.5434 & 2.42 \\
8.3284 & 2.11 \\
4.3200 & 1.10 \\
2.7585 & 0.70 \\
\hline
\end{tabular}

environmental variables is examined on the basis of the collecting data described in the previous section: The first variable I chose is localities that are influenced by two distinct sea currents. The coasts of Hokkaido are mainly influenced by two major sea currents: Kuroshio (subtropical water) and Oyashio (subarctic water). The coast of the Japan Sea side of Hokkaido is mainly influenced by the warmer Kuroshio, and the other coasts are by the colder Oyashio all the year round. The second variable is substrates that offer space and food materials for halacarids.

A regional distribution pattern and occurrence of rhombognathines on particular substrates are given as locality-species and substrate-species matrices respectively (Tables 2 \& 3). No clear association of rhombognathines with localities influenced by two major sea currents is detected from the distribution pattern of the mites in Hokkaido (Table 2). Likewise, distinct association between rhombognathines and particular substrates is not recognized from the occurrence pattern of the mites on various substrates in Hokkaido (Table 3).

There is a possibility that the present result on the regional distribution is highly influenced by the sampling frequency. The highest number of species is observed in Oshoro (locality No. 17) at which the most intensive sample-collecting has been carried out. The occurrence of rare species will increase as more sampling effort is given to the other localities. Therefore, the further analysis is made only on substrate preferences but not on the locality-species relationship.

The correspondence for 35 substrates and 16 species are analyzed to examine whether substrate preferences exist in the rhombognathines in Hokkaido. The correspondence analysis (Benzécri, 1973, 1992) is performed using PROC CORRESP in SAS (SAS Institute, 1990) at the Hokkaido University Computing Center, Sapporo.

The analysis of correspondence supports above mentioned interpretation of substratespecies relationship. No clear association is detected between particular substrates and rhombognathines in Hokkaido. The coordinates consisting of the first two axes contribute only $36.29 \%$ of the total variance of the corresponding character distribution (Table 4 ).

$\mathrm{My}$ attempt for detection of substrate preferences of rhombognathine mites in Hokkaido came to naught in the present study. Contrary to the present result, however, significant positive correlation was recognized in halacarids and particular species of algae on British rocky shores (Pugh \& King, 1985) and on the coast of South Georgia (Pugh \& Bartsch, 1993). 
In these investigations, correlation between halacarids and substrates was analyzed on the basis of quantitative data. Failure to detect significant correlation between the rhombognathines and substrates in Hokkaido might be due to that the present analysis was based only on qualitative data.

\section{Acknowledgments}

I wish to express my sincere gratitude to Dr. Shunsuke F. Mawatari, Dr. Masanori Toda and Dr. Haruo Katakura, Hokkaido University, for their critical reading of the manuscript. Thanks are also due to Mr. Satoru Saitô, Hokkaido University, for his assistance with statistical computations.

The following persons have generously given their help with the present study by providing gifts or information of materials or accommodating the author during visits: Mr. Kazurô, Shinta, Oshoro Marine Biological Station, Hokkaido University ; Dr. Shin Kubota, Hokkaido University (presently Seto Marine Biological Laboratory, Kyoto University) ; Dr. Nobuyo Yoshida, Hokkaido University (presently Tohoku National Agricultural Experimental Station); Dr. Hiroshi Namikawa, Hokkaido University (presently National Science Museum, Tokyo); Mr. Hiroshi Hoshikawa, Hokkaido Institute of Mariculture; Mr. Yasuhiro Kuwahara, Hokkaido University (presently Hokkaido Wakkanai Fisheries Experimental Station); Dr. Kazuo Kido and Mr. Noritaka Ueda, Econix Co. Ltd., Sapporo; Messrs. Yasutake Hiraiwa, Naohiro Muroya, Yoshinobu Takashima and Kazuhiro Ueno, Hokkaido Tokai University. This work was supported in part by a research grant from the Akiyama Foundation.

\section{References}

Abé, H. 1990a. Method in the studies of halacarid mites. A guide to collection, preparation and identification. Seibutsu Kyouzai, $25: 21-45$ (text in Japanese).

Abé, H. 1990b. Three new species of the genus Rhombognathus (Acari, Halacaridae) from Japan. Zool. Sci., $7: 517-535$.

Abé, H., Kito, K., Aryuthaka, C. \& Tamura, H. 1993. Use of a photographic slide mount for nematode preparations. Nematologica, $39: 135-137$.

Alberti, G. 1979. Fine structure and probable function of the genital papillae and Claparede organs of Actinotrichida. In: Rodriguez, J. G. (ed.), Recent Advances in Acarology, Vol. 2. Academic Press, New York, San Francisco and London, pp. 501-507.

Alberti, G. \& Storch, V. 1977. Zur Ultrastruktur der Coxaldrüsen actinotricher Milben. Zool. Jb. Anat., 98: 394-425.

André, M. 1946. Halacariens marins. Faune de France, 46: 1-152.

Bartsch, I. 1972. Ein Beitrag zur Systematik, Biologie und Ökologie der Halacaridae (Acari) aus dem Litoral der Nord- und Ostsee. I. Systematik und Biologie. Abh. Verh. naturew. Ver. Hamburg (N. F.), $16: 155-230$.

Bartsch, I. 1973. Porohalacanus alpinus (Thor) (Halacaridae, Acari), ein morphologischer Vergleich mit marinen Bemerkungen zur Biologie dieser Art. Ent. Tidskr., 90 : 116-123.

Bartsch, I. 1974a. Ein Beitrag zur Systematik, Biologie und Ökologie der Halacaridae (Acari) aus dem Litoral der Nord- und Ostsee. II. Ökologische Analyse der Halacaridenfauna. Abh. Verh. naturew. Ver. Hamburg (N. F.), 17: 9-53.

Bartsch, I. 1974b. Über das Auftreten von Epimeralporen besonders bei den Rhombognathinen (Halacaridae, Acari). Zool. Anz., 193: 266-268.

Bartsch, I. 1975a. Beitrag zur Halacaridenfauna der Eulitorals bei Banyuls-sur-mer (Mittelmeer) (Halacaridae, Acari). Mitt. hamb. zool. Mus. Inst., 72: 137-155.

Bartsch, I. 1975b. Ein Beitrage zur Rhombognathinen-Fauna (Halacaridae, Acari) der Bretagnekïste. Acarologia, 17: 53-80.

Bartsch, I. 1977. Interstitielle Fauna von Galoapagos XX. Halacaridae (Acari). Mikrofauna Meeresboden, $65: 1-108$.

Bartsch, I. 1978. Verbreitung der Halacaridae (Acari) im Gezeitenbereich der Bretagne-Küste, eine 
Ökologische Analyse. I. Verbreitung der Halacariden. Cah. Biol. mar., 19: 363-383.

Bartsch, I. 1979a. Halacaridae (Acari) aus der Subantarktis. Cah. Biol. mar., 20: 325-339.

Bartsch, I. 1979b. Verbreitung der Halacaridae (Acari) im Gezeitenbereich der Bretagne-Küste, eine Ökologische Analyse. II. Quantitative Untersuchungen und Faunenanalyse (1). Cah. Biol. mar., $20: 1-28$.

Bartsch, I. 1982. Halacaridae (Acari) von der Atlantikküste des borealen Nordamerikas. Ökologische und tiergeographische Faunenanalyse. Helgoländer Meeresunters., 35 : 13-46.

Bartsch, I. 1983. Zur Halacaridenfauna der Philippinen Beschreibung von fünf Arten der Gattung Rhombognathus (Acari, Halacaridae). Entomol. Mitt. zool. Mus., 7 : 399-416.

Bartsch, I. 1985. New species of Halacaridae (Acari) from New Zealand. N. Z. J. Zool., 12 : 547-560.

Bartsch, I. 1986. New species of the genus Rhombognathus (Acari, Halacaridae), and key to Mediterranean Rhombognathus. Bull. Mus. Hist. nat. Marseille, 46(1) : 3-7.

Bartsch, I. 1989. Marine mites (Halacaroidea: Acari) a geographical and ecological survey. Hydrobiologia, 178: 21-42.

Bartsch, I. 1990. Halacaridae (Acari) of Hong Kong. In: Morton, B. (ed.), The Marine Flora and Fauna of Hong Kong and southern China II. Hong Kong Univ. Press, Hong Kong, pp. 661-665.

Bartsch, I. 1992. Hong Kong Rhombognathinae mites (Acari : Halacaridae). In: Morton, B. (ed.), The Marine Flora and Fauna of Hong Kong and southern China III, B. Hong Kong Univ. Press, Hong Kong, pp. 251-276.

Bartsch, I. \& Schmidt, P. 1979. Zur Verbreitung und Ökologie einiger Halacaridae (Acari) in Sandstränden der Ostsee (Kieler Bucht), der Nordsee (Sylt) und des Europäischen Nordmeeres (Tromsö). Mikrofauna Meeresboden, 74: 1-37.

Benzécri, J.P. 1973. L'Analyse des Données: T. 2,1' Analyse des Correspondances. Dunod, Paris.

Benzécri, J.P. 1992. Correspondence Analysis Handbook. Marcel Dekker, New York.

Colman, J.S. 1939. On the faunas inhabiting intertidal seaweeds. J. Mar. Biol. Assoc., 24: 129-184.

Evans, G.O. 1992. Principles of Acarology. C.A.B. International, Wallingford, 563 pp.

Fashing, N.J. 1988. Fine structure of the Claparede organs and genital papillae of Naiadacarus arboricola (Astigmata: Acarudae), an inhabitant of water-filled treeholes. In: ChannaBasavanna, G.P. \& Viraktamath, C.A. (eds.), Progress in Acarology, Vol. 1. Oxford \& IBH Publishing, New Delhi, pp. 219-228.

Gosse, P.H. 1855. Notes on some new or little known marine animals. Ann. Mag. nat. Hist., 2e 16: 27-36, 305-306.

Green, J. \& Macquitty, M. 1987. Halacarid Mites. Synop. Br. Fauna (N.S.), 36 :1-178.

Krantz, G.W. 1976. Arenicolous Halacaridae from the intertidal zone of Schooner Creek, Oregon (Acari : Prostigmata). Acarologia, 18: 241-258.

Lohmann, H. 1889. Die Unterfamilie der Halacaridae Murr. und die Meeresmilben der Ostsee. Zool. Jb. Syst., $4: 269-408$.

Lohmann, H. 1893. Die Halacarinen der Plankton-Expedition. Ergebn. Plankt.-Exped. HumboldtStift., 2 (G. a. $\beta$.) : 13-95.

Lohmann, H. 1907. Die Meeresmilben der Deutschen Südpolar Expedition 1901-1903. Deutsche Südpolar-Exped. 1901-1903., 9 (Zool.) : 361-413.

Moore, P.G. 1973. The kelp fauna of northeast Britain. II. Multivariate classification: Turbidity as an ecological factor. J. exp. mar. Biol. Ecol., 13: 127-163.

Newell, I.M. 1947. A systematic and ecological study of the Halacaridae of Eastern North America. Bull. Bingham. Oceanogr. Coll. New Haven, 10(3) : 1-232.

Newell, I.M. 1967. Prostigmata: Halacaridae (Marine Mites). Entomology of Antarctica. Antarct. Res. Ser., $10: 81-95$.

Newell, I.M. 1984. Antarctic Halacaroidea. Antarct. Res. Ser., 40: 1-284.

Pugh, P.J.A. \& Bartsch, I. 1993. Ecology of the littoral Halacaridae (Acari : Prostigmata) of South Georgia in the sub-Antarctic. J. Nat. Hist., 28: 75-85.

Pugh, P.J.A. \& King, P.E. 1985. Vertical distribution and substrate association of the British Halacaridae. J. Nat. Hist., 19: 961-968.

SAS Institute. 1990. SAS user's guide: Statistics. Ver.6, 4th ed. SAS Inc., Raleigh, North Carolina. 
Sokolov, I.I. 1952. Halacarae. Fauna SSSR, 5(5) : 1-201.

Trouessart, E.L. 1888. Note sur les Acariens marins recueillis par M. Giard au laboratoire maritime de Wimereux. C.R. Acad. Sci., 107: 753-755.

Trouessart, E.L. 1889a. Acariens marins (Halacaridae) des côtes de France. Naturaliste, 58: 181.

Trouessart, E.L. 1889b. Revue synoptique de la familie des Halacaridae. Bull. scient. Fr. Belg., 20: 225-251.

Trouessart, E.L. 1899. Description d'espèces nouvelles d'Halacaridae. Bull. Soc. Etud. scient. Angers, $29: 209-227$.

Viets, K. 1927a. Die Halacaridae der Nordsee. Zeitschr. wiss. Zool., 130 : 83-173.

Viets, K. 1927b. Halacaridae. Tierwelt N. -u. Ostsee, 10 (11c) : 1-72.

Viets, K. 1936. Spinnentiere oder Arachnoidea VII, Wassermilben oder Hydracarina. In: Dahl, F. (ed.), Tierwelt Deutschlands, Gustav Fischer Verlag, Jena, 574 pp.

Viets, K. 1939. Meeresmilben aus der Adria (Halacaridae und Hydrachnellae, Acari). Arch. Naturgesch. (N. F.), 8: 518-550.

Viets, K. 1940. Meeresmilben aus der Adria (Halacaridae und Hydrachnellae, Acari). Arch. Naturgesch. (N. F.), 9: 1-135.

Wieser, W. 1952. Investigations on the microfauna inhabiting seaweeds on rocky coasts. IV. Studies on the vertical distribution of the fauna inhabiting seaweeds below the Plymouth Laboratory. J. Mar. Biol. Assoc., 31 : 145-174.

Yates, F. 1934. Contingency tables involving small numbers and the Chi test. J. R. Stat. Soc., Suppl. 1: $217-235$. 